\title{
Espaços de cemitério e a cidade de São Paulo
}

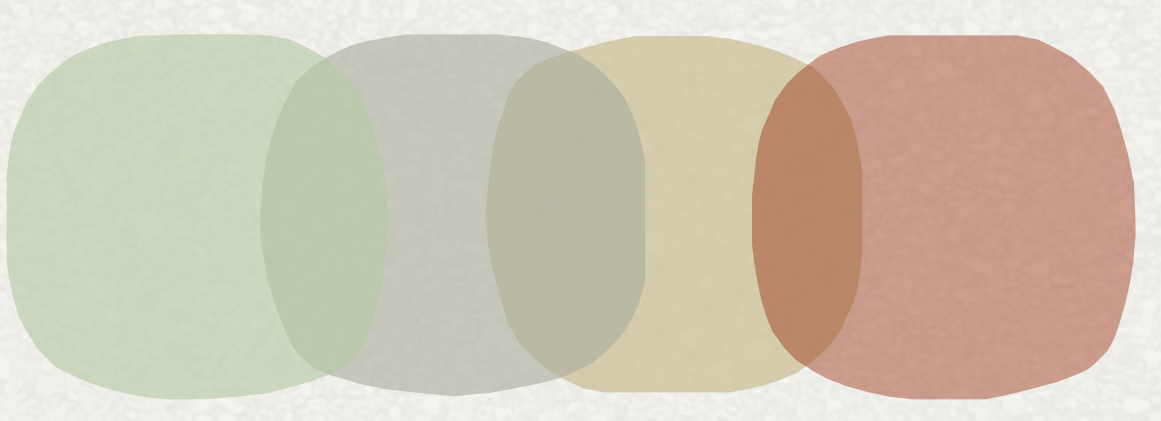

Felipe Fuchs 

Dissertação de Mestrado apresentada ao Programa de Pós-Graduação em Arquitetura e Urbanismo da Faculdade de Arquitetura e Urbanismo da Universidade de São Paulo para a obtenção do título de Mestre em Arquitetura e Urbanismo

\section{Espaços de cemitério e a cidade de São Paulo}

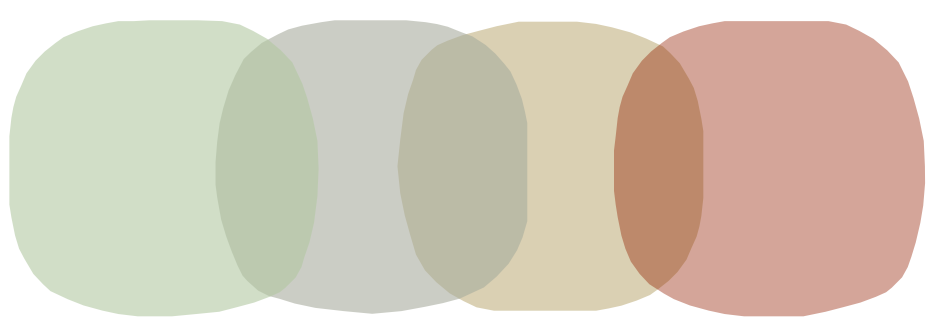

Felipe Fuchs

2019

Área de Concentração

Orientador

Paisagem e Ambiente

Eugenio Fernandes Queiroga 
Autorizo a reprodução e divulgação total ou parcial deste trabalho, por qualquer meio convencional ou eletrônico, para fins de estudo e pesquisa, desde que citada a fonte.

E-mails do autor: fuchsfelipe@hotmail.com; felipe.fuchs@usp.br

Catalogação na Publicação

Serviço Técnico de Biblioteca

Faculdade de Arquitetura e Urbanismo da Universidade de São Paulo

Fuchs, Felipe

Espaços de cemitério e a cidade de São Paulo / Felipe Fuchs; orientador Eugenio Fernandes Queiroga. - São Paulo, 2019.

$236 \mathrm{p}$.

Dissertação (Mestrado) - Faculdade de Arquitetura e Urbanismo da Universidade de São Paulo. Área de concentração: Paisagem e Ambiente

1. Cemitérios 2. Espaços Urbanos Livres 3. Espaços de Memória e Luto 4. Áreas Verdes 5. Paisagem Urbana 6. Vida e Morte.

I. Queiroga, Eugenio Fernandes, orient. II. Título. 
Agradeço aos familiares e amigos pela constante ajuda e apoio; aos professores Igor Guatelli e José Guilherme Magnani pela enorme colaboração dada na banca de qualificação; aos entrevistados e às entrevistadas que contribuíram com relatos fundamentais para o desenvolvimento do trabalho; ao Eugenio Queiroga pela orientação atenta e generosa durante a elaboração desta dissertação. 



\section{Resumo}

Esta dissertação se propõe a discutir os espaços de cemitério nas cidades contemporâneas através de análises, estudos, experiências e perspectivas relativas a esses locais. Tendo em mente a complexidade envolvida na temática fúnebre, a pesquisa busca desenvolver a relação entre vivos e mortos e a sua influência na composição e posição desses espaços junto à cidade. A partir desse embasamento, procura-se discutir sobre as percepções dos cemitérios, de modo a refletir sobre como eles poderiam ser vistos em um contexto de constante transformação social e urbana. Tomando como referência a conjuntura da cidade de São Paulo, são colocados possíveis caminhos para uma articulação dos espaços de cemitério junto à vida cotidiana, buscando considerar tanto os aspectos afetivos e sensíveis envolvidos nestes locais, quanto o seu potencial de usufruto.

Palavras-chave: cemitérios; espaços livres urbanos; espaços de memória e luto; áreas verdes; paisagem urbana; vida e morte 



\section{Abstract}

This dissertation proposes to discuss cemetery spaces in contemporary cities based on related analyzes, studies, experiences and perspectives. Considering the complexity involved in discussing mortuary themes, the research seeks to develop connections between the living and the dead, as well as their influence on the composition and position of these spaces within the city. Taking this into account, the work aims to discuss the perceptions of the cemeteries in order to reflect on how they are seen in a context of constant social and urban transformation. Focusing on the city of São Paulo, the research imagines possible ways in which the cemetery can be articulated with daily life, contemplating the affective and sensitive aspects of these spaces, along with their potential for social and urban accomplishment.

Keywords: cemetery; open space; urban landscape; green areas; spaces for memory and grief; life and death 



\section{Lista de imagens}

$\begin{array}{ll}\text { Img.01 Tomb, de Christoph Niemann } & \text { p.19 }\end{array}$ www.christophniemann.com

Img.02 Sem título, de El Sr. Garcia www.elsrgarcia.com

Img.03 Sem título, de Quino

Déjenme inventar, Buenos Aires: Edifciones de La Flor, 2003, p.80

Img.04 Vue du cimetière du Père-Lachaise depuis l'entrée, de Pierre Courvousier www. 1st-art-gallery.com/Pierre-After-Courvoisier/Pierre-After-Courvoisieroil-paintings.html

Img.05 Montagem com fotos Mount Auburn Cemetery

a 08 Fotos gentilmente cedidas por Isaac Safdie, 2017-18

Img.09 Highgate Cemetery www.magx.com/bizarre/highgate-cemetery-londons-great-victorian-cemetery.html

Img.10 Eixo Parques e Cemitérios de São Paulo

Fábio Penteado: ensaios de arquitetura. São Paulo: Empresa das Artes, 1998

Img.11 Tipologias de construções fúnebres

Clarissa Grassi, 1 a 7 (Memento Mortuorum: inventário do Cemitério Municipal São Francisco de Paula em Curitiba/PR, 2016), com complemento do autor 8 e 9

Img.12 Memorial Parque das Cerejeiras

Foto do autor, 2017

Img.13 "Cinetério" no Cemitério Consolação (folhapress)

Folhapress (Gabriela Biló) www.entretenimento.band.uol.com.br/ noticias/100000707498/cemiteriodaconsolacaoexibefilmesdeterror.html

Img.14 "Pedal Caveiras" no Cemitério Consolação www.metrojornal.com.br/foco/2017/11/01/passeio-de-bike-em-sao-pauloabre-homenagem-aos-mortos.html

Img.15 Sem título, de Quino

Quien anda ahí, Buenos Aires: Edifciones de La Flor, 2016, p.118

Img.16 Cemitérios do Município de São Paulo (Nomes e localização) Mapa feito pelo autor com base em dados do Serviço Funerário do Município e de informações coletadas via site e telefone com as entidades particulares 
Img.17 Cemitérios do Município de São Paulo (Tamanhos)

Mapa feito pelo autor com base em dados do Serviço Funerário do Município e de informações coletadas via site e telefone com as entidades particulares. No caso daqueles que não foi possível encontrar informações, recorreu-se a ferramentas como o Daft Logic Google Maps Area Calculator Tool

Img.18 Cemitérios do Município de São Paulo (Tipologia cemiterial)

p.102

Mapa feito pelo autor com base em visitas e visualização de imagens aéreas dos locais

Img.19 Cemitérios do Município de São Paulo (Período de fundação)

p.103

Mapa feito pelo autor com base em dados do Serviço Funerário do Município e de informações coletadas via site e telefone com as entidades particulares

Img.20 Montagem com fotos do Memorial Parque das Cerejeiras

p.105

a 24 Fotos do autor, 2017

Img.25 Sem título, de El Sr Garcia

p.115

www.elsrgarcia.com

Img.26 Cemitério de Powazki, em Varsóvia

p.121

foto gentilmente cedida por Carolina Junqueira dos Santos

Img.27 Lápide no Cemitério Alter St. Matthäus, em Berlim

p.124

Foto gentilmente cedida por Aline Yamamoto

Img.28 Panóptico (Interior View of Cell House, new Illinois State Penitentiary) www.mediastudies.it/IMG/pdf/Panopticon-2-4.pdf

Img.29 Border, de Hammock www.mak.at/zeichen_gefangen_im_wunder_2013-01-23

Img.30 Comparação de consumo energético e emissão de carbono por método de tratamento do corpo

Diagrama feito pelo autor com dados retirados de www.deathlab.org

Img.31 Skogskyrkogården

www.ottsworld.com/blogs/skogskyrkogarden-cemetery

Img.32 Terreno de Enterro Natural

Imagem retirada de video do GreenAcres Natural Burial Ground www.youtube.com/watch? $=\mathrm{cVmhWA}$ _wRW0

Img.33 Memorial Nécropole Ecumênica em Santos www.melhordesantos.com/2011/04/memorial-necropole-ecumenica-o-maior-do.html

Img.34 Cemitério Yarkon em Tel Aviv www.haaretz.com/jewish/israel-building-cemetery-towers- 1.5316506 
Img.35 Phoenix Memorial em Santo André

www.phoenixmemorial.com.br

Img.36 Shinjuku Rurikoin Byakurengedo

p.160

www.hiddenarchitecture.net/2017/02/shinjuku-ruriko-in-byakurenge-do.html

Img.37 Cemitério San Cataldo

a 39 fotos de Laurian Ghinitoiu retiradas de www.archdaily.com/95400/ad-classics-san-cataldo-cemetery-aldo-rossi

Img.40 Cemitério de Igualada www.arquiscopio.com/archivo/2012/06/26/cementerio-de-igualada/?lang=pt

Img.41 Cemitério Finistierre

p.165 www.césarportela.com/\#/cementerio-municipal-de-fisterra

Img.42 Cemitério de Courtrai

p.166 www.miesarch.com/work/1235

Img.43 Cemitério Beausoleil

Img.45 Cemitério Villa Armea www.calviceschiavigano.it/portfolio/ampliamento-cimitero-comunale-valle-armea

Img.46 WPA 2.0

p.170 www.deathlab.org/wpa-2-0 www.deathlab.org/constellation-park

Img.48 Sylvan Constellation www.deathlab.org/sylvan-constellation

Img.49 Proposta vencedora de concurso internacional para um cemitério vertical em

a 50 Tóquio $A$ morte não é o fim, ser esquecido é www.archoutloud.com/death-is-not-the-end.html

Img.51 Dia de Finados no Cemitério da Vila Formosa

Img.59 Visitante cuidando de túmulo no Dia de Finados, Cemitério da Vila Formosa p.181 Foto do autor, 2018

Img.60 Cemitério da Vila Formosa, implantação

Base de desenho Mapa Digital da Cidade, www.geosampa.prefeitura.sp.gov.br com edição e desenho do autor feito sob imagem aérea do Google Earth 
Img.61 Cemitério da Vila Formosa, vista aérea

Montagem com imagens do MDC (Geosampa) e Google Earth, feita pelo autor

Img.62 Vista de uma quadra e das campas de terra

Foto do autor, 2017

Img.63 Túmulo da Menina Débora

Foto do autor, 2018

Img.64 Vista de uma quadra com árvore

Foto do autor, 2018

Img.65 Jardineiro cuidando de um dos túmulos

Foto do autor. 2017

Img.66 Bosque com troncos de árvores marcados por práticas de alguns dos frequentadores

Foto do autor, 2017

Img.67 Crianças pedalando junto às quadras do cemitério

Foto do autor, 2018

Img.68 Morador da vizinhança passeando com cachorro

Foto do autor, 2017

Img.69 Mapa de Tipos Socioambientais

Mapa Digital da Cidade (Geosampa). PMSP, SMDU, 2014.

Img.70 Mapa de cobertura de Acesso a Lazer e Cultura

Mapa Digital da Gidade (Geosampa). PMSP, SMDU, 2014.

Img.71 Cemitério da Vila Formosa, vista voo de pássaro www.mapio.net/pic/p-105537620, com edição do autor

Img.72 Reportagem na Folha de S.Paulo em 7 de julho de 1986 de manifestação contra o "Projeto Polstergeist" www.f5.folha.uol.com.br/saiunonp/2014/05/1448878-ladroes-tarados-edoencas-infestam-cemiterios.shtml

Img.73 Memoriais em Homenagem aos Desaparecidos na Ditadura Militar

a 76 do Cemitério da Vila Formosa

foto do autor, 2017

Img.77 Túmulos em Gamla Uppsala

WORPOLE, Ken. Last landscapes: the architecture of the cemetery in the West. Londres: Reaktion Books, 2003. 
Img.78 Trecho de ossário e (também muro do cemitério)

Foto do autor, 2017

Img.79 Córrego Água Rasa e Rio Aricanduva

Imagem Google Earth, traçado MDC (Geosampa), montagem feita pelo autor

Img.80 Córrego Água Rasa na parte central do cemitério

Foto do autor, 2018

Img.81 Sem título

www.elsrgarcia.com, com edição do autor

Img.82 São Paulo e o Cemitério de Vila Nova Cachoeirinha, na zona norte

Google Street View, com edição do autor

Img.83 São Paulo e o Cemitério Gethsemani Morumbi, na zona oeste

Google Street View, com edição do autor

Img.84 São Paulo e o Cemitério Campo Grande, na zona sul

Google Street View, com edição do autor

Img.85 São Paulo e o Cemitério Dom Bosco, na zona norte

Google Street View, com edição do autor

Img.86 São Paulo e o Cemitério de Itaquera, na zona leste

Google Street View, com edição do autor

Img.87 São Paulo e o Cemitério Lajeado, na zona leste

Google Street View, com edição do autor

Img.88 São Paulo e o Cemitério de Santana, na zona norte

p.218

Google Street View, com edição do autor

Img.89 São Paulo e o Cemitério São Luís, na zona sul

p.218

Google Street View, com edição do autor

Img.90 São Paulo e o Cemitério São Paulo, na zona oeste

p.218

Google Street View, com edição do autor

Img.91 São Paulo e o Cemitério São Pedro, na zona leste

Google Street View, com edição do autor

Img.92 São Paulo e o Cemitério Israelita do Butantã, na zona oeste

Google Street View, com edição do autor

Img.93 São Paulo e o Cemitério da Saudade, na zona leste 
Img.94 São Paulo e o Cemitério da Vila Formosa, na zona leste

a 99 Google Street View, com edição do autor

Img.100 Os Cemitérios de São Paulo - Os 40 cemitérios de São Paulo em fevereiro de 2019

Desenhos feitos pelo autor a partir de imagens aéreas do Google Earth e bases da Prefeitura de São Paulo disponíveis em <www.prefeitura.sp.gov.br/ cidade/secretarias/desestatizacao/projetos/cemiterios/index.php?p=236439> Acesso em: 21 dez. 2018. 


\section{Lista de siglas}

DEPAVE Departamento de Parques e Áreas Verdes

FUNDASP Fundação São Paulo

LEM-IPUSP Laboratório de Estudos sobre a Morte do Instituto de Psicologia da Universidade de São Paulo

$\mathbf{M} \& \mathbf{V} \quad$ Programa Memória \& Vida

MDCG Movimento em Defesa do Cemitério da Consolação

MDG Mapa Digital da Cidade de São Paulo

PDE Plano Diretor Estratégico

PMSP Prefeitura Municipal de São Paulo

PUG Pontifícia Universidade Católica

SAPAVEL Sistema Municipal de Áreas Protegidas, Áreas Verdes e Espaços Livres

SFM Serviço Funerário do Município de São Paulo

SIURB Secretaria Municipal de Infraestrutura Urbana e Obras

SMDP Secretaria Municipal de Desestatização e Parcerias

SMPR Secretaria Municipal das Prefeituras Regionais

SMSO Secretaria Municipal de Serviços e Obras

SP São Paulo

SMDU Secretaria Municipal de Desenvolvimento Urbano

SVMA Secretaria do Verde e do Meio Ambiente

TGM Tribunal de Contas do Município

USP Universidade de São Paulo 



\section{Sumário}

Introdução p.21

Prólogo p.25

01 Escamoteamento da morte $\quad \mathbf{p . 3 3}$

02 Cemitérios Eclesiásticos p.37

03 Revolução Cemiterial $\quad \mathbf{p . 4 1}$

04 Modelos do Século XIX $\quad \mathbf{p . 5 1}$

05 Expansão $\quad$ p.61

$\underline{\text { Parte I p.31 }}$

06 Cemitério Público e p.73

A Imagem do Cemitério

Cemitério Particular

07 Cemitérios de São Paulo $\quad$ p.83

$\underline{\text { Parte II p.107 }}$

Sentidos e Percepções
08 Morte, Ausência, Semiótica

09 Vínculos: Memória, Religiosidade, Luto

10 Subjetividades: Polissemia, Paradoxo

11 Intersecções: Coexistências, Limiares p.109

p.113

p.125

p.131

\section{Parte III p.141}

Possibilidades e Desígnios

12 Rumos e Vestígios

p.143

13 Perspectivas

p.153

14 O Cemitério da

p.181

Vila Formosa

Considerações finais p.213

15 Possibilidades

p.195

$\underline{\text { Referências } \quad \text { p.225 }}$ 



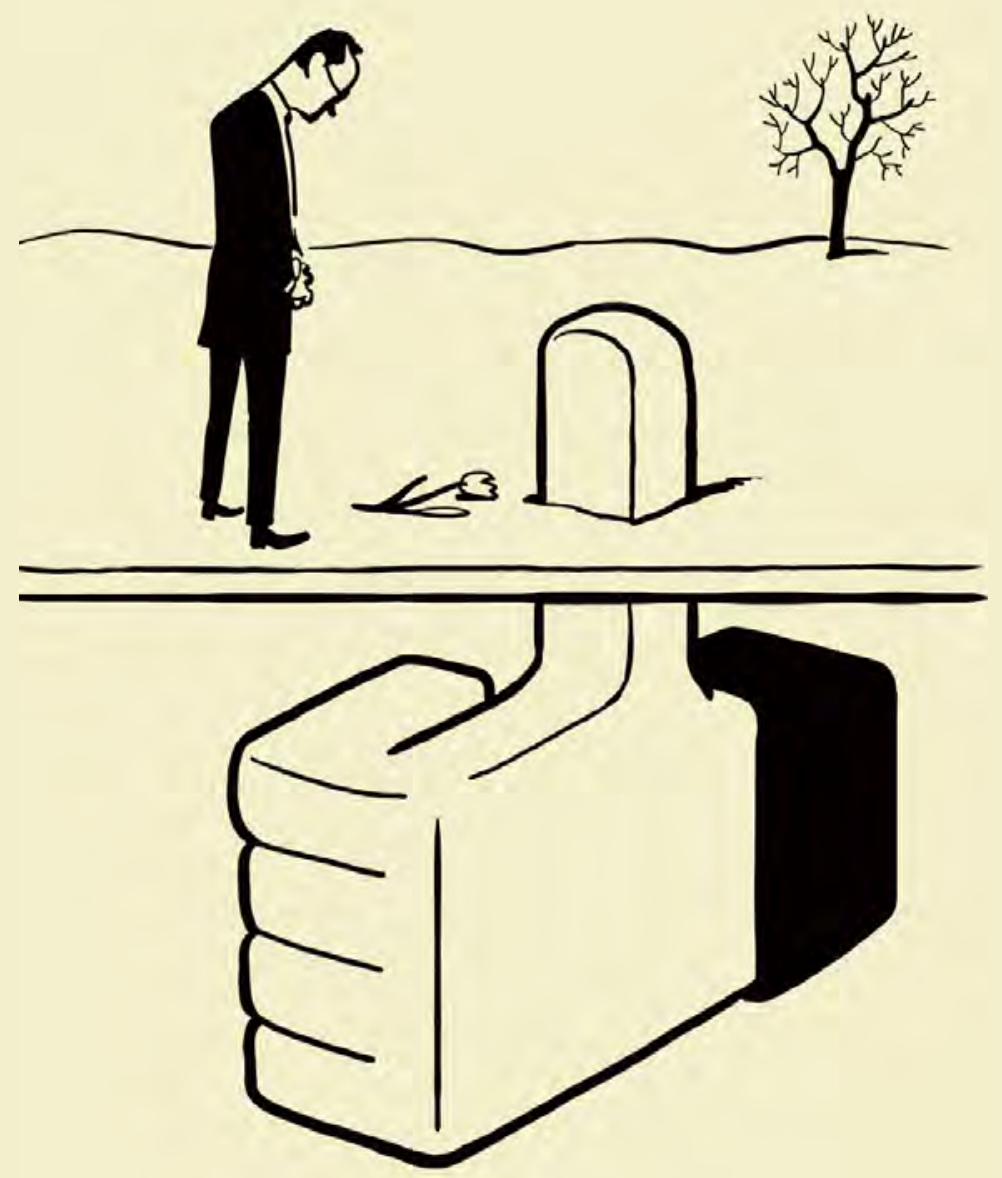





\section{Introdução}

Na tentativa de encontrar uma forma de abordar os temas tão diversos que a morte e o cemitério suscitam, optou-se por organizar a dissertação em três partes, além desta presente introdução, do prólogo e das considerações finais.

A opção pela elaboração de um prólogo foi feita com o intuito de apresentar elementos essenciais para o desenrolar da pesquisa. Os assuntos nele tratados procuram não apenas introduzir a temática traçada, mas também apresentar sensações e pensamentos que acompanharam o processo de elaboração deste trabalho.

Em relação ao escopo da dissertação, a Parte I é composta por sete tópicos. Em (1) Escamoteamento da morte, busca-se introduzir o contexto onde a morte se configurou como um assunto-problema. No segundo item, (2) Cemitério Eclesiásticos, é apresentada a conjuntura anterior a este momento de escamoteamento da morte, de forma a oferecer um panorama de como ela foi sendo transformada até chegar no período que aqui é chamado de (3) Revolução Cemiterial. Então, a 
partir do entendimento das circunstâncias que levaram ao surgimento dos cemitérios modernos, são desenvolvidos os principais (4) Modelos de espaços cemiteriais decorrentes desse processo, e os meios como este tipo de espaço ganhou lugar e passou por uma (5) Expansão, mostrando as divergências e contratempos encontrados. Por fim, com maior atenção às particularidades do caso do Brasil e de São Paulo, são apresentados aspectos do (6) Cemitério Público e Cemitério Particular e são desenvolvidas as qualidades e especificidades dos (7) Cemitérios do Município de São Paulo.

Desse modo, a Parte I pode ser entendida como uma espécie de descrição da formação e conformação dos cemitérios paulistanos e da construção da relação (ou falta dela) entre estes espaços, a sociedade e a cidade. A partir desta conjuntura, busca-se embasar as discussões seguintes sobre os cemitérios, principalmente no sentido de entender como e quando eles se tornaram assuntos vedados, além de entender as influências que levaram à configuração vigente da maior parte dos cemitérios no contexto brasileiro. Com este panorama, procura-se consolidar um suporte para se pensar os principais atributos e significados dos espaços cemiteriais.

Já a Parte II é formada por quatro tópicos. Em (8) Morte, Ausência, Semiótica, discute-se a ideia de ausência envolvida na temática da morte, de modo a subsidiar as noções de (9) Memória, Religiosidade, Luto. Estas concepções são fundamentais para o desenrolar da discussão proposta, servindo como parâmetro para guiar a reflexão sobre as conexões entre os aspectos afetivos e sensíveis da morte e a capacidade dos espaços de oferecer sensações de acolhimento e conforto às pessoas. Na sequência, em (10) Subjetividades: Polissemia e Paradoxo, são trazidas reflexões sobre a confluência de variados significados atrelados aos espaços de cemitério, de modo a desenvolver discussões sobre os pontos de encontro entre as diversas nuances presentes. No último tópico desta parte, (11) Intersecções: coexistência e limiares, são discutidas instâncias de ações e percepções dos cemitérios que apresentam ou permitem o surgimento de concomitâncias em seus espaços. 
A Parte II trabalha, então, aspectos mais ligados às subjetividades, afetividades e sensibilidades existentes no âmbito dos cemitérios. Nesse sentido, através dos tópicos trazidos, procura-se tanto apresentar conceitos chaves para se pensar nos espaços cemiteriais, como instigar reflexões sobre os sentidos e percepções desses lugares.

A Parte III é formada por mais quatro tópicos. Em (12) Rumos e Vestígios são desenvolvidos pontos para se pensar sobre as formas de se lidar com o tema do corpo morto em um contexto contemporâneo. De forma similar, em (13) Perspectivas, são trazidas algumas iniciativas e propostas que podem contribuir para se pensar as formas de configurar os espaços fúnebres nesta conjuntura. Assim, em (14) O Cemitério da Vila Formosa, apresentam-se alguns aspectos de um dos espaços fúnebres mais marcantes de São Paulo, de modo a pensar as formas de relação entre cemitério e cidade imaginando, a partir deste lugar, as (15) Possibilidades que os seus espaços oferecem para reflexão.

Portanto, a Parte III procura apresentar considerações mais empíricas e objetivas, compreendendo temas atrelados às contingências, aos desígnios e às formas de relação com os espaços de cemitério. Desse modo, expondo ideias, críticas e reflexões, ela se aproxima mais da ideia de ensaio, no sentido de trazer discussões sobre as qualidades e maneiras de se imaginar o espaço fúnebre.

Por fim, em relação às considerações finais, optou-se por configurar uma espécie de fechamento reflexivo da dissertação, mais do que uma síntese. Retomando a dimensão da finitude, passando pelos meios como a conformação de uma cidade como São Paulo lida com seus espaços e pela reflexão sobre a importância dos cemitérios, buscou-se salientar a abrangência e a indefinição que é parte do processo de pensamento sobre os espaços fúnebres. 



\section{Prólogo}

\section{$\underline{\text { Finitudes }}$}

Ao longo do desenvolvimento da pesquisa de mestrado, é inevitável deparar-se com perguntas como sobre o que é sua pesquisa. Acompanhando outros pesquisadores, desde antes do início deste trabalho, encontrei respostas das mais variadas: curtas, compridas, específicas, genéricas, definidas, reflexivas, etc. A cada pergunta feita, buscava me esforçar mais em conseguir uma melhor explicação, procurando uma espécie de aprovação ou de reconhecimento da relevância da pesquisa. Não durou muito tempo para querer mudar. Se no início estava mais preocupado em encontrar o jeito mais didático de explicar, com o tempo passei a me interessar mais pela reação das pessoas. Então, decidi por começar a responder de forma bastante sucinta: estudo a relação do cemitério com a cidade, ou, simplesmente, estudo cemitério.

Assim, focando nas diversas reações ao tema da pesquisa, comecei a perceber que dificilmente havia uma postura de indiferença. Gostando ou desgostando, ficou claro pelas reações dos interlocutores 
como o tema suscitava respostas extremas. Muito repugnante para uns, a ponto de em alguns casos a conversa morrer logo de cara, com um certo incômodo e uma expressão de "não quero falar disso" ou, "por que você está fazendo isso com você?". Muito promissor para outros, mostrando entusiasmo, dúvidas e uma vontade de saber mais, o que levou a ricas discussões.

Percebi então que, de certa forma, o trabalho parece ser muito mais radical do que pretende ser, apenas por tratar da temática da morte. Portanto, para lidar com essa problemática, foi preciso desenvolver uma argumentação a respeito da importância de falar sobre mortalidade porque, de forma abreviada, isso contribui para lidar com o assunto. Quando não lidamos com o tema da morte, quando sabemos que vamos morrer e não queremos pensar ou falar sobre isso, há um tipo de corrida para se viver mais. Assim, estabelece-se uma luta intransponível contra a morte, que tende a se tornar algo temido e assustador. Por outro lado, ao optar pelo diálogo, é possível aceitá-la mais facilmente. Ao falar mais sobre a morte, é possível fazer com que o assunto se torne menos assustador, ajudando a assimilar e refletir sobre a mortalidade. Assim, uma espécie de máxima começou a andar comigo, ajudando a estabelecer mais clareza frente a essas situações. Se, num primeiro momento, estudar cemitério é estudar morte, foi ficando claro que falar de morte é, antes de mais nada, falar de vida. O cemitério foi então se mostrando um objeto que, para além da sua complexidade urbana, exigia uma transdisciplinaridade. Desde então, como pesquisador, passei a fazer um esforço em busca de entender as variadas e diferentes perspectivas que esse tema pode abarcar.

Com os psicólogos, aprendi que falar de morte é falar de trauma, de dor, e ajuda a evitar mais mortes. Com os historiadores, aprendi que falar de morte é entender como viviam as civilizações anteriores ao nosso tempo e como eram as disputas 
de cada período. Com os antropólogos, aprendi que falar de morte é falar de cultura, práticas e tradições das mais variadas possíveis. Com os sociólogos, aprendi que falar de morte é falar de sistema social, de poder e controle. Com os filósofos, aprendi que falar de morte é falar do sentido da vida, da existência, é falar de finitude. Como coloca Catroga:

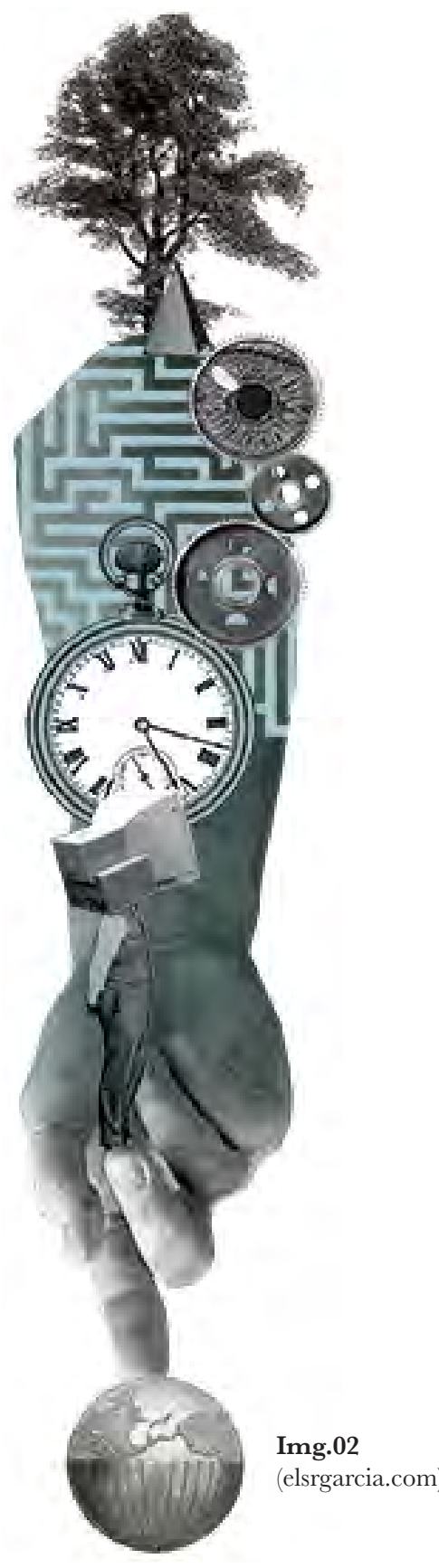

“...apreender o sentido do inaceitável definhamento é um dos requisitos necessários para se tentar apreender o tempo; ou melhor, o homem como tensão entre um futuro que ainda não é e um passado que já não existe. Logo, o morrer, sendo intrínseco à vida, surge como o problema radical que, em vez de ser recalcado, nos pode ensinar a compreender e a saber vivê-la. E, como da morte só poderemos reconhecer a sua semiótica, os discursos tanatológicos serão sempre uma fala de (e sobre) os vivos."

(CATROGA, 2009, p. 164)

Desse modo, a partir da discussão proposta, percebe-se que a morte física não basta para realizar a morte na consciência. A memória e a importância daqueles que morreram continuam vivas através daqueles a elas vinculadas. A consciência não consegue pensar o morto como morto e por isso não pode se furtar a lhe atribuir uma certa vida. Portanto, como arquiteto-urbanista-paisagista, espero que aproximar-se desse tema, que falar sobre morte e do seu lugar no espaço social e urbano, seja também falar sobre a vida desses lugares que, por fim, são frequentados e direcionados aos vivos.

Assim, se num primeiro momento o entendimento do espaço de cemitério junto à cidade era o foco singular da pesquisa, ao longo do seu processo de desenvolvimento a força da temática da morte ganhou importância, incitando questões sobre o encaminhamento e a delimitação da pesquisa. Como abordar os cemitérios

Img.02

(elsrgarcia.com) 
dentro de uma perspectiva espacial e urbana sem omitir a dimensão simbólica e filosófica da finitude? A pesquisa deve se restringir a uma disciplina, um determinado espaço-tempo, um estudo de caso? Se for o caso, como adotar uma abordagem pragmática tendo como objetivo fornecer chaves de leitura e de atuação frente aos desafios da cidade contemporânea?

A busca por essas respostas se depara com uma difícil e infindável discussão a respeito da forma como lidamos com o tema da morte. As formas de se pensar são inúmeras, são tantas quanto as pessoas. A beleza da compreensão da finitude através da morte pode estar justamente na capacidade de se reconhecer essas narrativas e se abrir à complexidade, com todos os sentimentos ambíguos e as contradições que possam existir. Dessa maneira, o espaço de cemitério se apresenta como portador de uma complexidade paradoxal. Ao adentrá-lo, introduz-se uma atmosfera em que as ideias de vida e morte dialogam, em que é preciso buscar conciliação entre elas. O cemitério apresenta nosso destino e nossa destinação, revelando-se como um espaço de natureza singular, das mais sensíveis. Ao mesmo tempo, o cemitério, como espaço social e urbano, deve interessar aos arquitetos como parte integrante da infraestrutura da cidade. É essencial considerá-lo não como um objeto perturbador e isolado, mas dentro de uma perspectiva de aproximação da vitalidade urbana e do cotidiano de uma cidade como São Paulo.

Assim, as páginas que seguem procuram refletir e discutir sobre a relação entre cemitério e cidade, tendo em vista as experiências pessoal, simbólica, sensorial, social, espacial e urbana. Todo o esforço deste trabalho concentrou-se na discussão de elementos que podem ser usados como subsídio para um tipo de pensamento e de projeto que busque reconstruir a forma como os espaços de cemitério são entendidos e abordados, analisando os possíveis caminhos para uma mediação. 


Parte I

\section{A Imagem do Cemitério}





\section{Escamoteamento da morte}

Como forma de melhor compreender a condição dos espaços de cemitério na atualidade, esta pesquisa se inicia com a caracterização da relação entre morte e cidade no ocidente e dos meios como ela foi constituída até este começo de século XXI. A intenção é primeiramente construir o cenário que conduziu à percepção corrente de morte na sociedade ocidental ${ }^{1}$ contemporânea, para na sequência pensar as suas possíveis desconstruções e discutir as novas configurações que têm surgido na relação entre a cidade, os seus habitantes vivos e os seus residentes mortos. Nesse sentido, a elucidação do percurso de formação e de consolidação

1 A dicotomia ocidente-oriente remonta à época do Império Romano onde era usada como forma de diferenciação dos aspectos geográficos e culturais entre o leste e oeste do globo. O conceito de ocidente ganhou diversas interpretações com o tempo, sendo marcante o período de Guerra Fria onde adquiriu também contornos políticos e econômicos. Em relação ao Brasil, não há um consenso se o país está integralmente alinhado com o que hoje são considerados os países do mundo ocidental, como Estados Unidos e as principais potências europeias. Se por um lado a colonização europeia deixou marcas na língua e no modelo de país, o subdesenvolvimento socioeconômico e a ditadura que marcou a região recentemente pode ser considerada motivo para deixar o Brasil de fora do grupo dos chamados países ocidentais. No entanto, para efeito desta pesquisa, que tem como foco questões de caráter cultural, comportamental e religioso, será adotado o termo mundo, país ou cemitério ocidental, de forma a alinhar o Brasil aos países supracitados. 
dos cemitérios visa substanciar a posterior discussão sobre o que simbolizam esses espaços, criando uma estrutura para se pensar e discutir o assunto do ponto de vista socioespacial e urbanístico. O esforço para entender esse contexto busca evidenciar e reconhecer a complexidade em lidar com o tema da morte no contexto presente.

De modo a iniciar essa reflexão, destaca-se um grande ponto de inflexão que transformou as relações com a morte, ocorrido há muito menos tempo do que se costuma imaginar: a constituição de uma sociedade que se recusa a discutir a morte, silenciando-se a seu respeito. Há aproximadamente dois séculos, a morte passou a ser vista como um problema, consolidando-se como objeto de um interdito. O historiador Philippe Ariès (2002), defende que este sentimento é algo característico da modernidade, que buscava evitar o incômodo e as emoções provocadas pela morte em contraste com a ideia de felicidade, de uma vida que deve ser feliz, ou ao menos parecer sê-lo. Na mesma linha, Edgar Morin (1970, p.199) escreveu que "na impossibilidade de suprimir a doença e a morte, o homem resolveu que o melhor, para ser feliz, era não pensar de qualquer modo nisso".

O entendimento dessa inflexão é fundamental para os

2

Atualmente, pesquisadores contemporâneos discutem esta oposição, argumentando que o conceito que melhor se oporia à morte seria o nascimento, construindo assim uma relação distinta com morte. (Bate-papo $A$ morte em diferentes culturas, com Edgard Carvalho, Ailton Krenak, Christine Greiner e Acácio Almeida, SESC, realizado em novembro de 2017). estudos relativos à morte nas últimas décadas, configurando o que se pode chamar de um escamoteamento da morte do cotidiano. Desde então, falar de morte tornou-se desconfortável, desagradável, terrível. Até os dias atuais, a regra segue sendo a neutralização e a ocultação dos assuntos relativos a esse tema. A sociedade ocidental desenvolveu um pensamento de morte como oposição à vida ${ }^{2}$, baseado em uma concepção de que a vida é um bem, e a morte, correspondente à sua privação, é um mal. Esta tese da negação da morte foi bastante desenvolvida por muitos pensadores do pós-guerra, com destaque para Geoffrey Gorer, Philippe Áries, Michel Vovelle, Edgar Morin e Louis-Vincent Thomas, mantendo-se ainda bastante atual. Percebe-se como a maneira pela qual a morte é removida da vida diária segue demonstrando certo desconforto de uma sociedade na qual a morte e os mortos não são bem recebidos. Evita-se pensar sobre o tema, porém, nos momentos em que não é possível escapar, 


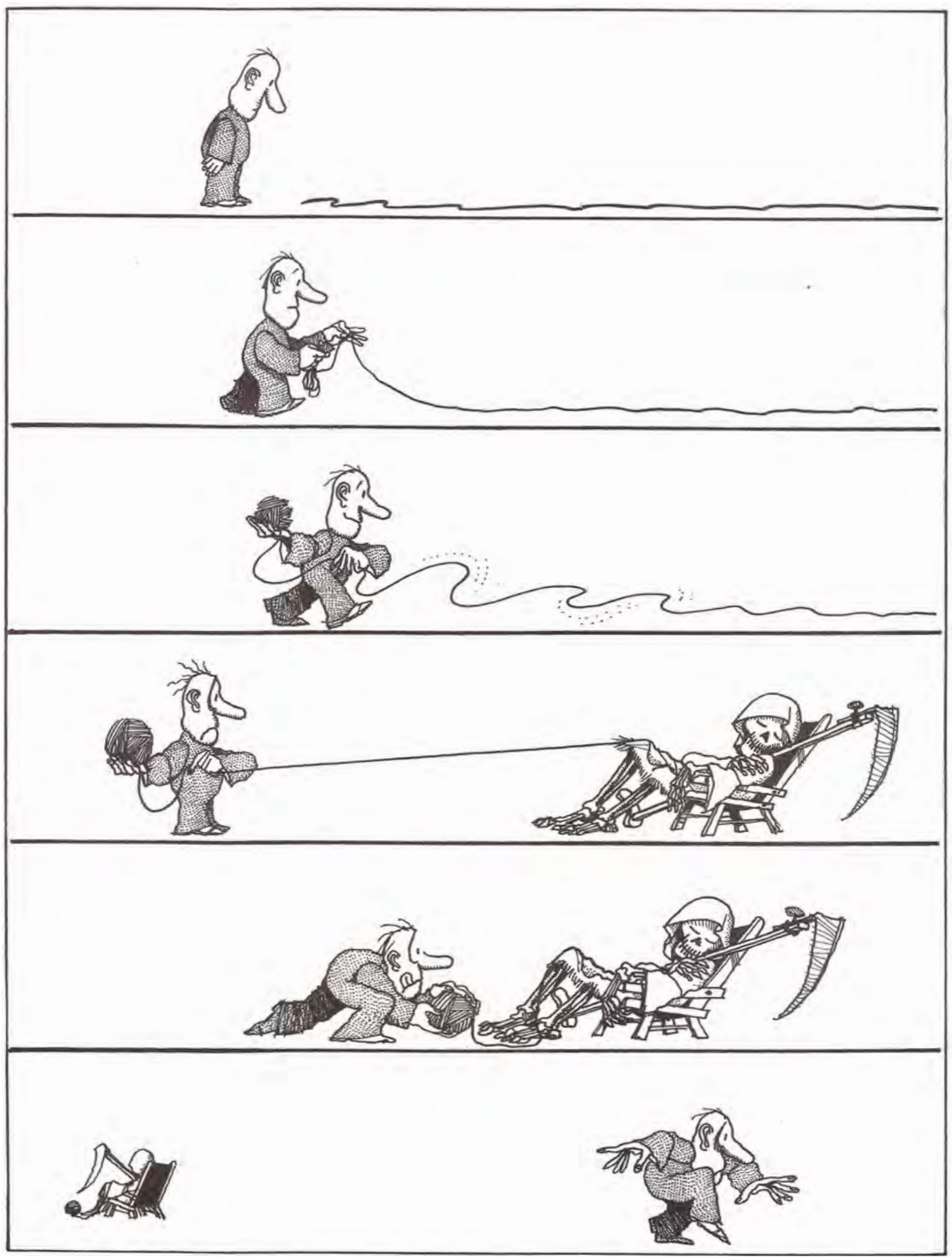

Img.03 (Quino) 
costuma-se estar despreparado, aumentando a sensação de desamparo e de sofrimento. Dessa forma, é válido refletir, conforme sugerido por Bayard (1996), se não seria melhor começar a falar da morte a fim de superar a nossa angústia.

Recentemente, cada vez mais tem crescido o número de pesquisas e de discussões sobre o tema, recolocando os trabalhos desenvolvidos no pós-guerra em pauta, ao mesmo tempo em que são abertas novas interpretações. Pesquisadores contemporâneos têm se debruçado sobre o assunto, buscando abordagens que tentam entender como a morte, o morrer e a dor são apreendidos no dia a dia da sociedade. Desse modo, abre-se o caminho para se discutir a relação entre vida e morte. Assim, expandindo as formas de compreensão e a capacidade de reflexão, pretende-se trazer novas questões e novas apropriações condizentes com as mudanças apontadas pela sociedade e as formas de prática atuais, que parecem cada vez mais diversificadas. Colocando em destaque a singularidade final da morte, surgem pesquisas que desenvolvem essa questão através de uma aproximação com os lugares e meios físicos (cemitério, sepultura, jardim memorial, etc.), e mais recentemente através da mediação de meios imateriais (cemitérios virtuais, redes sociais, páginas comemorativas, etc.). As transformações têm ocorrido em todas as áreas, por exemplo, a própria "supervisão" da morte também está se diversificando, envolvendo em menor grau profissionais religiosos e cada vez mais outros profissionais como psicólogos, agentes sociais e grupos de ajuda.

O conteúdo desenvolvido a seguir tem como base estas variadas fontes, de modo a subsidiar as posteriores discussões sobre espaço e cidade. São autores que se dedicaram a essa missão de forma versada e perspicaz, ao qual recorreremos constantemente. Assim, como coloca o antropólogo José Carlos Rodrigues, cabe refletir sobre qual o sentido de se seguir tratando o tema da morte como um tabu em nossa sociedade:

"Os sistemas de compatibilização da vida e da morte, que fazem o tudo conviver
com o nada, o aqui com o além, e assim por diante, são eminentemente paradoxais.
Mas, um sistema que represente pelo silêncio é o cumulo dos paradoxos. E o
silêncio sobre a morte em uma sociedade que tem a morte como sua realidade
mais barulhenta é o paradoxo dos paradoxos." (RODRIGUES, 2006, p.101) 


\section{Cemitérios Eclesiásticos}

O aspecto da maior parte dos cemitérios ocidentais como conhecemos hoje tem origem na concepção cristã de preservar e repousar o corpo após a morte, à espera da ressureição. Como conta Ariès (2010), esse ponto de vista foi difundido através da hegemonia da Igreja Católica, desde o princípio da Idade Média até o século XVIII. Neste período, o pressuposto fundamental para se lidar com os corpos dos falecidos era o sepultamento próximo aos santos e mártires, que protegiam as sepulturas do profano e libertavam os indivíduos dos pecados cometidos em vida. Pouco importava o destino preciso dos corpos, desde que estivessem perto de recintos sagrados, as capelas e igrejas, que garantiam a salvação e a destinação das almas para o céu.

A lógica de proximidade com os santos funcionava a partir de uma questão métrica, quanto mais perto em relação aos pontos sagrados, como o altar e as relíquias, mais próximo da salvação a pessoa estaria. Por se tratar de locais com espaço físico limitado para uma questão de ordem crescente como o número de mortos, havia um limite espacial para a organização dos enterros. Desse modo, foi estabelecida uma divisão, determinando quais eram os "melhores" locais, isto é, 
mais próximos aos altares e relíquias, e os "piores", mais afastados. Formalmente, essa divisão levou a configuração de uma segregação social entre aqueles que em vida detinham um maior poder social e econômico, portanto conseguiam ser enterrados nos "melhores" lugares, e aqueles com pior posição social e econômica. Aos que não conseguiam lugar no interior das igrejas devido às elevadas taxas que eram cobradas pelos eclesiásticos, restavam os pátios e os adros das igrejas. Portanto, na prática, os enterros se davam dentro das igrejas para os ricos e nos seus pátios para os pobres.

Configuravam-se assim os graveyards ${ }^{3}$, palavra até hoje usada como sinônimo de cemitério em idiomas de raiz anglo-saxã, sendo muitas vezes confundida com churchyard, justamente pelo costume de usar os terrenos ao redor das igrejas como local de enterro. Esses locais constituem basicamente o que eram os cemitérios da época medieval, marcando uma relação entre os vivos e os mortos bastante distinta da que temos atualmente. Vovelle, ao comentar o trabalho de Ariès sobre a história da morte no ocidente, definiu a sociedade da Idade Média como "uma sociedade em que coabitam os vivos e os mortos, em que o cemitério se confunde com a igreja no coração da cidade” (1976, p.126, tradução nossa).

De fato, em grande parte do período medieval não havia uma separação radical entre a vida e a morte, ou entre a cidade dos vivos e a cidade dos mortos, como se percebe atualmente. Se hoje este tipo de relação pode até parecer indecente ou pornográfico ${ }^{4}$, anteriormente ele era a regra. Para compreender este fenômeno, é necessário estar ciente de que a familiaridade entre estes

3 Tomando a língua inglesa como referência, temos uma diferenciação entre os graveyards e os cemeteries. Essa diferenciação se perdeu em algum momento em línguas latinas, que possuem como sinônimo do termo cemitério palavras que trazem outra conotação, como campo-santo ou necrópole. Como forma de se referir aos cemitérios no período em que a Igreja detinha o controle sobre os corpos falecidos, a pesquisa adota o termo cemitério eclesiástico ou cemitério medieval. Alguns autores chamam esses espaços de cemitérios urbanos, pois eles se localizavam no interior da cidade, termo que não será usado para não confundir com a ideia de cemitérios junto às cidades em uma perspectiva contemporânea.

4 A respeito da associação entre pornografia e morte, Geoffrey Gorer (1955) escreveu um importante artigo chamado de The pornography of death, em que ele argumenta que a partir do século XX, o sexo e a morte trocaram de posições como temas proibidos na cultura ocidental. 
conceitos tinha como plano de fundo uma concepção coletiva do destino após a morte. Ariès explica que as pessoas daquele tempo eram profundamente socializadas e que essa socialização não separava o ser humano da natureza, sobre a qual não se era possível intervir, a não ser pelo milagre. Assim, a familiaridade com a morte era uma forma de aceitação da ordem da natureza e submissão à morte era uma das grandes leis da espécie. Nesse contexto, não havia a tentativa de se controlar ou de se escapar da morte, mas "aceitava-a simplesmente como justa" (ARIÈS, 2010, p.33).

Percebe-se através da obra desses autores que no mundo ocidental, por séculos, o lugar dos mortos era integrado àquele em que se vivia, compartilhando inclusive o espaço das igrejas no centro da vida social. Ao estarem localizados no âmago das cidades, os cemitérios eclesiásticos não eram simplesmente o lugar onde se enterrava os mortos, mas eram espaços abertos, onde as pessoas se reuniam para as mais variadas manifestações, dando a eles uma conotação próxima a de uma praça pública. Esses locais recebiam cotidianamente atividades sociais comuns da época como a realização de feiras, de exibições, de espetáculos de jogos e de música. Em suma, eles eram o lugar mais movimentado da cidade, onde se podia assistir a cenas corriqueiras, decorrentes da proximidade com a morte e da aceitação dela integrada à ordem da natureza (RODRIGUES, 2006).

Desse modo, no período medieval as pessoas frequentavam os cemitérios sem se impressionarem ou se incomodarem com a proximidade de corpos enterrados ou até expostos devido às intempéries. A cosmovisão da morte e do cemitério não segregava estes espaços do cotidiano da cidade. Todavia, cabe ressaltar que esse fenômeno ocorria não porque a morte e os mortos não inspirassem apreensão, temia-se a morte sim, mas esse sentimento era reservado para a morte sem aviso, trágica, sem preparação e, sobretudo, sem funeral e sepultamento adequados. Desde que os vivos cuidassem bem de seus mortos, enterrando-os segundo os ritos adequados, eles não representariam perigo espiritual. Assim, esse modo de entendimento atuava como forma de mediar as relações entre os vivos e os mortos, fundindo-os em uma comunidade que não precisava diferenciá-los do ponto de vista da ocupação espacial (REIS, 1991). 
Com o passar dos séculos, uma nova consciência passou a fazer parte do ideário da sociedade. Como conta Ariès (2010), a partir dos séculos XIII, começou a ganhar lugar uma concepção judicializada da morte, baseada na ideia de que no instante derradeiro será tomada uma decisão suprema sobre o destino da pessoa. Dessa forma, a angústia de ser julgado e o medo de ser preterido do livro da vida transformaram o entendimento sobre a morte, que passou a ser vista como um momento carregado de dúvidas e inseguranças. Essa mudança é a raiz da transformação da morte em um evento apavorante, comovendo uma sociedade que anteriormente não temia a morte. Como consequência desta concepção judiciária da morte, surge uma nova perspectiva a respeito da vida, a existência do ser através de uma biografia particular. A vida de cada indivíduo passa a ser entendida como a narrativa de uma história particular da qual a morte é, ao mesmo tempo, o episódio final e a apresentação dos fatos e eventos àqueles que irãojulgá-la. A narrativa funciona como o desdobramento da ideia de individualidade, onde cada um receberá uma sentença de salvação ou condenação eterna. Essa transformação marca o começo do declínio da concepção medieval coletiva sobre a morte, abrindo caminho para uma consciência que progressivamente se individualiza diante de Deus e dá lugar a uma angústia pessoal diante da morte (ARIÈS, 2010).

Essa percepção irá se consolidar gradativamente ao longo dos séculos seguintes, ganhando cada vez mais espaço junto a outras ideias trazidas pela modernidade que foram determinantes para a transformação da relação entre os vivos e os mortos. Entre elas, destaca-se o estreitamento dos laços familiares, a apropriação da morte pela medicina e o desenvolvimento de ideias higienistas impulsionadas por uma sucessão de episódios de epidemias contagiosas. Estabelecidos ao longo do século XVIII e alimentados principalmente por pensadores iluministas, essas ideias progrediram junto ao processo de secularização (ou de laicização), conformando o que Ariès definiu como uma atitude perante a morte caracterizada principalmente pela sua própria negação $(2010$, 2014). Nesse contexto, a responsabilidade pela questão dos corpos falecidos passa a ser discutida pela sociedade e seus principais representantes, ganhando a conotação de um problema de saúde pública, o que abre caminho para o surgimento de um novo tipo de cemitério, um local destinado exclusivamente aos sepultamentos e às questões fúnebres. 


\section{A Revolução Gemiterial ${ }^{5}$}

O processo de secularização ocorreu em diversas esferas da sociedade, tendo como principal mote a transferência de assuntos do regime religioso para o regime civil através da consolidação dos Estados modernos. No que concerne às questões relacionadas à morte, esse

5

Termo usado pelo historiador Fernando Catroga (1993). processo teve como sustentação a ideia de separação entre corpo e alma, que conduziu a sociedade a transformações tanto nos pensamentos como nos comportamentos preponderantes. A partir do fortalecimento dessa cisão, abriu-se espaço para o entendimento da morte como um inimigo externo a ser combatido. Como destaca Rodrigues (2006), a partir da separação entre alma e corpo, o mito da imortalidade da alma ganhou uma versão moderna, a amortalidade, onde a ideia da busca pela salvação eterna é progressivamente substituída pela esperança de se viver mais, de postergar a morte. Rodrigues demonstra que esse processo vem associado ao estabelecimento de um novo sistema econômico, caracterizado pela valorização ideológica do corpo vivo, medicalizado, amortal, que pertence a um ser humano disposto a viver 
a vida da melhor forma possível porque ela é única. Junto da compreensão da morte como o instante em que a alma deixa o corpo, esse fenômeno faz com que este último se transforme em algo intrinsecamente desprovido de dignidade. Ao separar o corpo da alma, a tradição funerária irá se desvincular progressivamente do cadáver e irá se dedicar ao espírito, distanciando-se das concepções religiosas ligadas à matéria, como a ideia da ressurreição. A partir dessa conjuntura, o cadáver passa a ser reivindicado como objeto de ciência, a prática da dissecação começa a ser cada vez mais adotada, trazendo a figura do médico para um papel protagonista sobre a morte.

Se até os séculos XVII e XVIII, como descreve Ariès (2010), o quarto daqueles em situação de morte iminente era entendido como um lugar público, tratado pela comunidade com certa familiaridade, a partir desse período os médicos irão protestar contra esse amontoamento, que passa a ser considerado uma invasão. Tendo como objetivo combater a morte, eles passaram a estipular regras baseadas em questões de higiene que alteraram progressivamente o caráter das cerimônias fúnebres, limitando-a aos familiares e íntimos do doente. Ainda, incutidos pela atribuição de prolongar a vida, os médicos também reivindicam a condução de outras questões relativas à morte como os enterros, entrando em disputa com as entidades religiosas responsáveis pelo assunto até então. Assim, passam a defender a dessacralização da morte, exigindo que a função de registrar óbitos fosse retirada dos padres, pleiteando, por assim dizer, a posse do cadáver a partir do instante da morte. Esse processo, conhecido como a medicalização da morte, vem associado ao avanço do conceito de morte natural que Rodrigues (2006) atrela à emergência de uma nova classe. Tradicionalmente, os médicos recusavam a obrigação de prolongar a vida, no entanto, sob os estímulos de uma classe de pessoas que se recusam a deixar a vida, normalmente homens brancos e ricos, este tipo de serviço passou a ser muito bem remunerado. Se a princípio eram raros estes casos, em meados do século XIX eles já eram bastante numerosos. São pessoas que só aceitam a morte em uma idade avançada, com boa saúde e em plena atividade (ARIÈS, 2010). Dentro desse novo panorama, falar sobre a morte se torna cada vez mais restrito. O silêncio é convencionado entre todas as partes, começando muitas vezes com o próprio paciente que solicita ao médico não revelar sobre seu estado. 
Desse modo, o médico vira detentor de um segredo profissional, que é também um segredo comercial na medida em que a vida de seu cliente é um capital valioso dentro das regras do sistema econômico (ARIÈS, 2010). Assim, a ideia de morte se direciona para um caminho onde ela fica cada vez mais difícil de ser discutida e, portanto, de ser aceita, encontrando cada vez menos espaço no dia a dia.

Como destaca Rodrigues (2006), a consequência de tudo isso é um pouco paradoxal: de um lado, é cada vez mais preciso se preparar para a morte, de outro, cada vez mais as responsabilidades sobre o que fazer após a morte são transferidas para os membros da família. O indivíduo quer cada vez menos pensar na própria morte e, mesmo doente, seu médico não o informa sobre a gravidade de sua condição. Então, como descreve Ariès (2010, 2014), a grande obstinação não é mais a própria morte, que começou a se transformar em tabu, mas a morte do outro, a morte do próximo, do amigo, do parente. A partir do século XVIII e sobretudo no século XIX, por omissão do indivíduo, são os familiares que passam a se ocupar da morte do próximo, temendo seu desaparecimento e cultuando sua memória depois do acontecimento. Essa apropriação dos assuntos relacionados à morte pela família é determinante para a mudança na relação do indivíduo com seu destino. Ele passa a ter a percepção de que à medida que a morte se aproxima, ele não vai estar mais só. Os parentes, que em outros tempos se mantinham apartados, vão acompanhá-lo até ao seu derradeiro fim, compartilhando esse momento que antes era reservado a Deus ou a si mesmo.

Essa transformação pode ser vista através dos testamentos ${ }^{6}$ da época. Até ao século XVIII, eles exprimiam as ideias e vontades para o post mortem, destacando a fé religiosa e as decisões pessoais tomadas na busca pela salvação da alma e pelo repouso do corpo. Ou seja, os testamentos eram usados de modo a tratar basicamente da destinação da própria pessoa em questão. A partir da segunda metade do século XVIII, com a mudança na compreensão das relações familiares, baseadas no sentimento e no afeto, ocorreu uma alteração considerável no sentido dos testamentos. Os termos religiosos, as designações de sepulturas e os recursos

6

Testamento vem do verbo testari, derivado da palavra latina testis, que originalmente significa o que entendemos hoje por testemunho, ou seja, o documento material ou declaração oral que é estabelecida ou mantida com um outro elemento a ser considerado a partir de uma circunstância entre as duas partes. 
destinados a missas e serviços religiosos perdem lugar e o testamento passa a ser utilizado como documento de distribuição de heranças, um instrumento jurídico de distribuição de bens e capital da família. Assim, conforme se estabelecia um novo grupo social baseado na valorização do indivíduo, tornava-se imprescindível que o capital se mantivesse dentro do núcleo familiar, garantindo a continuidade do poder econômico (RODRIGUES, 2006).

Paralelamente a essas transformações sociais, os sentimentos em relação aos cemitérios eclesiásticos começaram a mudar. A antes corriqueira proximidade entre vivos e mortos do período medieval passou a se tornar incômoda, convertendo o acúmulo de mortos no mesmo lugar em algo intolerável. Encabeçado pelos médicos, o discurso a respeito das questões de higiene e de saúde pública no trato com a morte transformou a percepção dos odores e das emanações dos cadáveres, que passaram a representar um perigo para a saúde, despertando repugnância e objeção. De forma geral, os médicos tinham uma visão na qual o funeral tradicional representava um "espetáculo de horror”. Assim, passaram a argumentar pelo fim do funeral medieval, que consideravam um "espetáculo", defendendo o ocultamento do morto de diversas maneiras, fosse encerrando-o em caixões fechados, fosse pela sua retirada dos centros urbanos (REIS, 1991).

Desse modo, através da congruência dos diversos fatores descritos como a medicalização da morte, o desejo por uma maior

Os romanos proibiam o enterro nas cidades, considerando que os mortos deviam estar situados em outro local, afastado da cidade dos vivos, que recebeu o nome

de necrópole, a cidade dos mortos. individualidade e a apropriação dos assuntos da morte pela família, passou-se a buscar uma nova solução para a questão dos cadáveres. Com isso, alguns grupos passaram a sustentar a ideia de se criar lugares específicos para destinação das sepulturas. Tendo como referência os romanos, que haviam separado o mundo dos vivos e o dos mortos através da Lei das Doze Tábuas ${ }^{7}$, passaram a sugerir que estes lugares deveriam estar localizados em regiões periféricas aos centros urbanos. A sustentação para essa transferência estava fundamentada principalmente no discurso dos médicos da época que 
defendiam a chamada doutrina dos miasmas. Para eles, a matéria orgânica em decomposição, especialmente de origem animal, sob a influência de elementos atmosféricos como temperatura, umidade e direção dos ventos, formava vapores ou miasmas nocivos à saúde, infectando o ar que se respirava. Contra esse novo "perigo" que os cadáveres passaram a representar, o distanciamento era considerado a solução mais adequada.

Esta nova percepção diante da morte e dos mortos ganhou espaço principalmente em território francês, onde a questão da morte se tornava um problema cada vez maior. No rastro de uma linha de pensamento racional, de laicização das relações sociais, e da secularização da vida cotidiana, uma nova consciência urbanística e higiênica passou a se manifestar. A administração pública deveria estar incumbida de legislar sobre o assunto, impondo novas regras oficiais de relacionamento com os mortos. Assim, em 1765, o Parlamento de Paris emitiu um decreto que ordenou a transferência das novas sepulturas para fora da cidade. Em 1776, uma declaração Real a respeito das inumações interditou definitivamente as sepulturas nas igrejas e nas cidades. Poucos anos depois, veio a ordem para o desmonte do Cemitério dos Inocentes, o maior de Paris, ocorrido entre 1785 a 1787. Episódio marcante na história de Paris, em dois anos foram retirados mais de 20.000 corpos do local, pertencentes a moradores da cidade ao longo dos nove séculos anteriores, e transportados para as chamadas catacumbas de Paris. Finalmente, o decreto de 23 Prairial, de 1804 estabeleceu a proibição do enterro nas Igrejas, obrigando as cidades a construírem cemitérios fora das suas regiões urbanizadas. Esse decreto, em vigor até hoje, foi o divisor de águas, modificando profundamente a sensibilidade à morte. A partir dele foram estabelecidos os primeiros cemitérios municipais nos arredores da cidade de Paris, como PèreLachaise, Montmartre, De Vaugirard e Montparnasse. Assim, num lapso de cerca de três décadas, transformaram-se profundamente hábitos milenares em relação à morte. 
O suporte para a criação desses novos locais foram os preceitos

Ressalta-se que

o termo cemitério

moderno é usado

aqui conforme

Ariès (2010), ou

seja, tendo como

referência o período

histórico moderno

que levou ao

surgimento deste tipo de lugar.

baseados principalmente na questão higienista, na valorização da individualidade e em uma moralização frente à morte, característicos do período. Esses tipos de cemitérios modernos ${ }^{8}$ foi pensado a partir da adoção de enterramentos individuais em detrimento do uso de fossas e valas comuns. Desse modo, a posição do túmulo no cemitério resultaria em um ordenamento da morte que não apenas seguia as normas de higiene e evitava o acúmulo de cadáveres, mas atendia às exigências do sentimento de individualidade, demarcando o lugar de cada sujeito. Quanto à localização ideal, ela teria que cumprir alguns requisitos, como um afastamento mínimo da zona urbanizada e de fontes d'água, além de uma implantação em terrenos altos e arejados, onde os ventos não soprassem sobre a cidade. Em torno deles deveriam ser construídos muros para evitar a entrada de animais e de saqueadores. Além dos muros, os novos cemitérios deviam ser cercados por árvores que deveriam purificar o ar e servir para embelezar a "morada da morte". Por fim, os idealizadores desses locais imaginavam que eles deveriam ensinar a grande lição da morte melhor que as igrejas, que não conseguiam colocá-la em prática. Para eles, a morte deveria igualar nobres e plebeus, sábios e ignorantes, ricos e mendigos. Os vivos sentiriam nesses espaços "o fim que nos é destinado", através de um ambiente onde os rituais inspirariam padrões de moralidade e não de religiosidade. Esses idealizadores se consideravam defensores da "legítima religião", em detrimento dos padres e das irmandades, que eram propagadores de algo "que nada tinha de religião" (REIS, 1991, p.261-262). A partir dessa nova configuração, os cemitérios eclesiásticos ganharam um ambíguo estatuto profano, tornando-se um espaço inapropriado para as orações cotidianas. Graças ao receio das epidemias, cujo contágio se procurava impedir, estabeleceu-se uma relação constante entre a peste, o demônio e a presença dos mortos. Com isso, estes espaços, antes vistos como os mais consagrados devido à presença dos santos e mártires, deixaram de ser vistos como locais abençoados justamente por causa dos mortos. 
No entanto, como qualquer grande ruptura, houve certa apreensão e foram realizados protestos contra as mudanças. Alguns grupos se opuseram fortemente à transferência dos mortos para o que consideravam a solidão em um local distante. Para eles, remover os mortos do contato diário com os vivos implicava não apenas uma falta de respeito com os falecidos, mas os deixaria desprotegidos em um ambiente sujeito a violação. Como argumenta Rodrigues (2006), a partir desse afastamento, a oposição entre o corpo e a alma materializou-se também nas concepções e projetos de urbanismo, com os argumentos de higiene prevalecendo sobre uma visão que buscava maior respeito aos mortos, que foram retirados à força dos lugares em que foram colocados por séculos. Com efeito, o sentido que se dá ao estabelecimento dos cemitérios fora das cidades é de que seu afastamento não beneficiaria apenas a cidade, que estaria livre do que era considerado uma fonte de contaminação, mas também o cemitério seria poupado da corrupção da cidade, de sua miséria e poluição, para ficar entregue à inocência e à pureza da natureza.

Por fim, cabe ressaltar que essas transformações ocorreram dentro de uma concepção de mundo que, embora transformada por influências secularizadoras, ainda era predominantemente religiosa. As resistências dos setores mais tradicionais, principalmente em regiões de hegemonia católica, levaram a uma transição onde foi necessário encontrar um ponto de conciliação. Para perceber isso basta atentar para as prerrogativas que a Igreja continuou e ainda continua a ter nos cemitérios (GATROGA, 2009). Assim, a partir das negociações entre os diversos atores da nova conformação dos espaços destinados aos mortos, a criação de espaços de cemitério afastados dos centros urbanos irá se tornar regra, estabelecendo uma transformação efetiva na relação entre os mortos e a cidade. O novo conceito de cemitério moderno, carregado de ideais iluministas e racionais, espalhou-se rapidamente, estruturando-se de modo a reproduzir e atender a conceitos do mundo dos vivos.

Ao mesmo tempo que resolvia questões trazidas pela nova percepção racional da sociedade, o afastamento dos cemitérios dos centros urbanos trouxe à tona um novo problema: a dificuldade da população de se manter em contato com os entes queridos falecidos. Com isso, novas formas de comportamento começaram a aparecer, estabelecendo um verdadeiro culto de veneração aos mortos. 
Junto ao movimento de transferência dos mortos, desenvolveu-se um sistema baseado na ideia de que cada sepultura individual representava o lugar a ser visitado pelos seus entes queridos, conformando-as como marcos territoriais. Assim, os familiares passaram a se vincular com o local de disposição dos restos mortais do falecido, demandando a concessão de um lugar dedicado exclusivamente a eles. A sepultura se converte então numa espécie de propriedade onde se vai para visitar o parente falecido como se vai à casa de um familiar, cheia de recordações (ARIÈS, 2010). Com isso, os túmulos passam a se configurar de modo a atender a funções determinadas como representar e proteger o morto, tornando-se objetos de elaborados projetos construtivos. Concebidos em forma de abrigo, eles começaram a ser pensados considerando escoamento das águas de chuva para fora da superfície de repouso do cadáver, afastando o risco de infiltração que pode corromper a integridade de um corpo que passou a representar uma identidade específica. Esse novo tipo de construção constituiu estes locais como um estabelecimento para o morto, um lugar que a família pode se apropriar e que deve se responsabilizar pelos cuidados. Esse processo representou mais uma grande transformação: a "privatização" desses lugares, que passam a concentrar os corpos dos parentes próximo sob um teto único para conservar e cultuar as suas memórias (URBAIN, 1978). Desse modo, o afeto que ligava os membros da família em vida, desloca-se para os mortos levando ao aparecimento dos túmulos familiares, que se tornaram bastante comuns durante a primeira metade do século XIX. A necessidade de reunir os mortos da família para todo o sempre, em um único lugar preservado, correspondeu a esse sentimento familiar crescente que se estendeu a todas as classes sociais do período.

Difundido principalmente durante o século XIX, esse hábito moderno chamado por Ariès (2010) de culto aos mortos foi paulatinamente assimilado tanto pelas igrejas cristãs como por outras formas de religião do mundo ocidental. Configurou-se como um culto laico, sendo praticado inclusive pelos que questionavam as ideias da Igreja, como os ateus e agnósticos, convertendo-se no que o Ariès (2010) chama de a única manifestação religiosa comum a crentes e descrentes de todas as confissões. Para o autor, a visita ao cemitério foi (e continua a ser) o grande ato permanente de religião no mundo ocidental. Aqueles que deixam de ir à igreja não deixam de ir ao cemitério, o que levou à criação de novos costumes como a visita em datas especiais e a 
colocação de flores que evocam o morto e cultivam a sua recordação. Essas práticas são hoje tão familiares que é comum se pensar que são bastante antigas, como se exprimissem uma constante fixa da natureza humana. No entanto, a partir do aprofundamento no estudo da criação dos cemitérios modernos, é possível perceber como, na verdade, são relativamente recentes. $\mathrm{O}$ culto aos mortos foi tão bem naturalizado, que se esqueceu das suas origens ${ }^{9}$.

Tendo em mente esse novo costume, os idealizadores do cemitério planejavam lugares que ofereciam lugares de paz e recolhimento, onde imaginavam que se deveria refletir sobre a morte e se pensar nos mortos. Nesses espaços, os recentes conceitos de valorização da individualidade ganharam cada vez mais espaço através da multiplicação dos túmulos individuais e da utilização de inscrições funerárias que expressavam a tentativa de assegurar a permanência do morto não mais somente no céu, mas também na Terra. Como será visto mais adiante, esse modelo de cemitério levou às últimas consequências o desejo da sobrevivência individualizada que, embora já fosse potencializada pela concepção cristã do post mortem e pela promessa de ressurreição final dos corpos, encontrou seu ápice no auge da modernidade (GATROGA, 2009). Essa tendência à individualização atingiu sua máxima significação ao longo do século XIX como o estabelecimento de leis que exigiam a construção de sepulturas individualizadas. Através da legislação, os próprios valores fundantes da nova sociedade garantiram o lugar a cada individuo, acenando a uma promessa de que todos podiam, finalmente, aspirar à imortalização da memória. A partir desse cenário, o cemitério cada vez mais se aproxima da configuração que se encontra hoje, oferecendo uma vastidão de sepulturas que aos poucos vão sendo identificadas por intermédio de imagens e de inscrições. A progressão da sepultura individual, do jazigo, do epitáfio, da estátua e, por fim, da fotografia ${ }^{10}$, devem ser vistas como consequência dos novos imaginários que cercam a lembrança dos vivos (CATROGA, 2009).

9

Sem dúvida existiram condutas similares nas famílias nobres do final da Idade Média, que consagravam seus mortos em túmulos no interior das capelas e das igrejas. Porém, esses casos, além de serem bastante raros, tinham como preocupação muito mais reverenciar a santidade $\mathrm{e}$ a notoriedade do falecido, do que a cultuar a fidelidade e a recordação (ARIÈS, 2010).

\section{0}

A descoberta da fotografia é contemporânea a esse período. Para ver mais sobre a relação entre fotografia e morte nesse período, ver Carolina Junqueira dos Santos, O corpo, a morte, a imagem: a invenção de uma presença nas fotografias e memoriais post-mortem, 2015. 



\section{Modelos do Século XIX}

\section{$\underline{\text { O estabelecimento de um modelo }}$}

Até o século XVIII ocorreram diversas transformações dos costumes e dos cuidados relativos aos enterros que, aos poucos, estabeleceram uma mudança estrutural na forma como lidar com a morte e com os corpos falecidos. Os "novos problemas" que os cemitérios eclesiásticos passaram a apresentar foram determinantes para essa transformação, levando à constituição do cemitério extra urbano como o lugar específico para disposição dos mortos. Com a consolidação desta concepção, passou a ser necessário encontrar um modelo para sua instituição. Como visto, motivada pelos então recentes acontecimentos históricos e pelos ideais iluministas, a cidade de Paris tomou a dianteira nesse quesito. O prefeito de Paris à época, Nicolas Frochot, foi quem coordenou a fundação do primeiro cemitério moderno, o Cemitério do Leste, mais tarde rebatizado como Cemitério de Père-Lachaise. Concebido pelo arquiteto Alexandre-Théodore Brongniart, inspetor chefe do departamento de obras públicas da cidade de Paris, o cemitério parisiense foi elaborado a partir de um desenho que intercalava grandes eixos junto a amplos espaços de jardim, providos de árvores e plantas de várias espécies, cercadas de sepulturas escultóricas (CHARLET, 2003). 
Dados retirados do site da Prefeitura de Paris. <sur mairie20.paris.fr> Acesso em: 29 nov. 2018.

12

Assim como na Idade Média, a proximidade com os restos mortais de indivíduos significativos seguia representando uma condição importante para a escolha do local de enterro.

Dados retirados do site da prefeitura de Paris. <sur mairie20.paris.fr> Acesso em: 29 nov. 2018.
O cemitério foi aberto oficialmente em 1804, sendo inicialmente utilizado para a relocação de corpos enterrados em outros espaços fechados no final do século XIX. O Père-Lachaise não agradou aos parisienses logo de início. Houve certa resistência em realizar enterros afastados do centro, em uma região considerado popular (CHARLET, 2003). Os dados oficiais mostram que no ano de inauguração, o local recebeu apenas $13^{11}$ sepulturas. Nos anos seguintes, os números também não ultrapassavam as dezenas, o que levou a prefeitura a buscar meio de incentivar o uso da área. Para tentar melhorar a imagem do cemitério, foi realizada a transferência dos restos mortais de figuras relevantes da cultura francesa, como Héloïse de Argenteuil, Pierre Abélard, Jean de La Fontaine e Molière ${ }^{12}$. Junto a isso, foi feita uma campanha de divulgação do desse espaço, que começou a ser citado em referências literárias, ajudando a trazer notoriedade para o local. Com isso, já em 1830, o cemitério passou a abrigar mais de 33 mil túmulos ${ }^{13}$, tendo que ser expandido para comportar mais sepulturas.

Assim, tendo como base os preceitos da secularização e do higienismo, o Père-Lachaise se apresentou como uma resposta propícia às novas características sociais e à demanda de afastamento dos mortos da cidade. Com o passar dos anos, o sepultamento no Père-Lachaise tornou-se uma questão de prestígio. $\mathrm{O}$ sucesso do Père-Lachaise acabou por consolidar a prática de sepultar cada corpo de modo individual, além de difundir o princípio do enterro perpétuo. Até os dias atuais o cemitério parisiense é um dos mais conhecidos e mais visitados do mundo devido à representatividade que conquistou ao longo do tempo, ganhando relevância como 


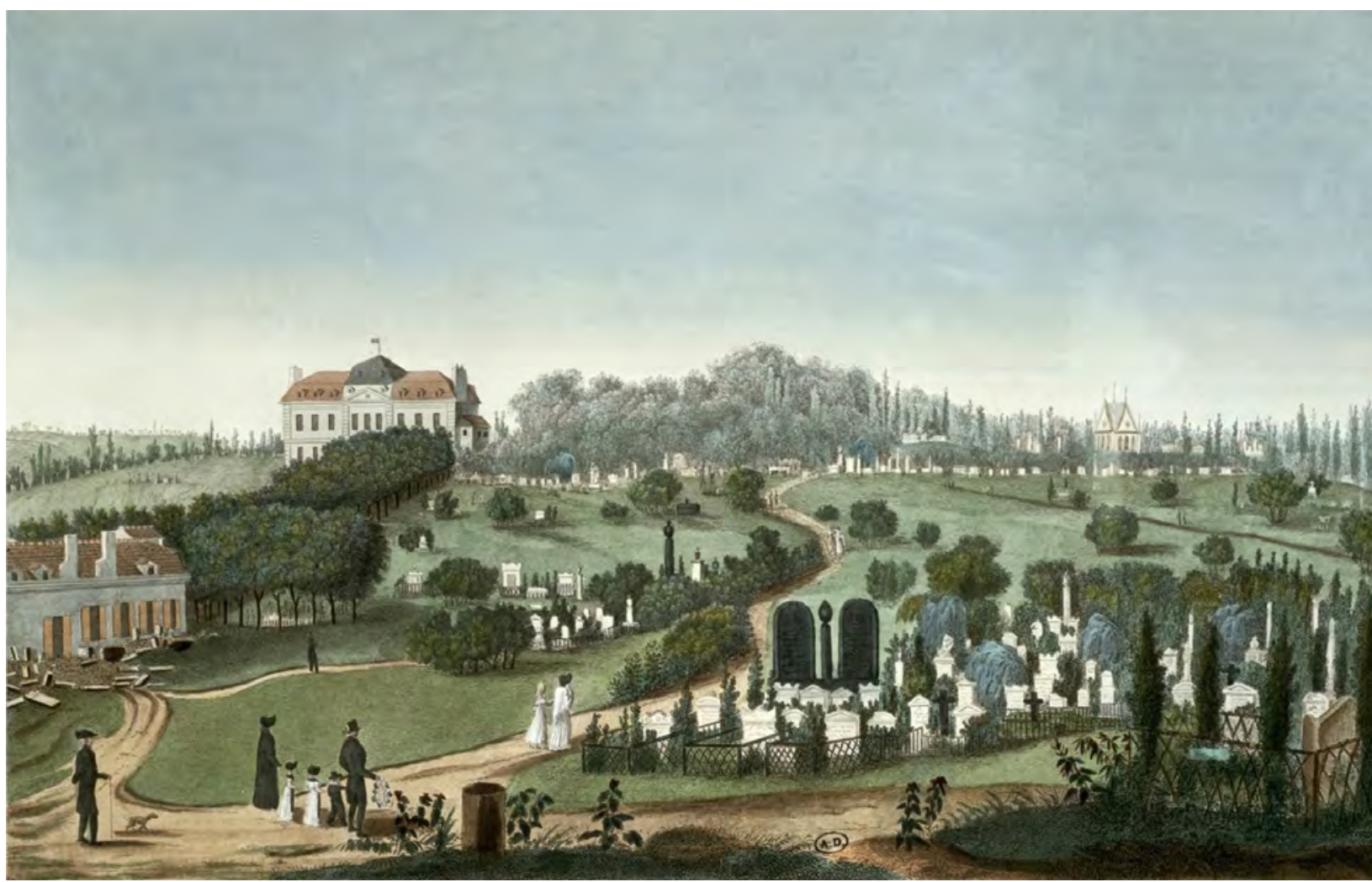

Img.04 Vue du cimetière du Père-Lachaise depuis l'entrée, de Pierre Courvousier (www.1st-art-gallery.com)

o primeiro cemitério de domínio e acesso público de grandes proporções. Como espaço precursor, a partir do seu exemplo foram estabelecidos grande parte dos novos cemitérios criados ao longo do século XIX e XX, trazendo novas peculiaridades de acordo com cada conjuntura. Nesse quesito, destaca-se o desenvolvimento dos cemitérios no contexto estadunidense, que trouxeram uma percepção da paisagem e da vegetação de forma bastante marcante, configurando-se como espaços fundamentais para a valorização destes aspectos no desenvolvimento urbano. 


\section{Cemitérios campestres}

Assim como na França, foi criado nos Estados Unidos um modelo de cemitério que buscava oferecer espaços seguros e atraentes à expressão dos sentimentos particulares de afeto crescentes na sociedade da época. Planejados a partir de uma releitura sobre o entendimento das questões de religiosidade, estes locais tinham seus princípios ligados ao desenvolvimento industrial e à veneração da horticultura. No modelo estadunidense, a paisagem girava em torno dos lotes de cada sepultura, introduzindo o conceito de uso da natureza de uma forma ostensiva e ornamental, associando-a a uma virtude moral através de um discurso que visava contrastar com as qualidades de uma cidade cinzenta. Esse tipo de cemitério ficou conhecido nos Estados Unidos como rural cemetery, que na tradução para o português se tornou cemitério rural, mas aqui será chamado de cemitério campestre ${ }^{14}$.

O principal expoente desse modelo de cemitério foi o Cemitério de Mount Auburn, fundando nos arredores de Boston, em 1831. Concebido a partir de uma sociedade de horticultura, a Massachusetts Horticultural Society, o local foi marcado pela grande presença de árvores, arbustos e plantas que, ao ser associadas aos espaços de sepultura, tinham como pano de fundo suscitar uma moral instrutiva em relação à morte e à mortalidade. Ganhava corpo na época a percepção de que o cenário natural tinha um impacto positivo nas pessoas, contribuindo para lidar com as dores e sentimentos frente à morte. Jacob Bigelow, o principal idealizador do cemitério, juntou-se ao paisagista Alexander Wadsworth para projetar espaços com preponderância de formas sinuosas, estabelecendo os caminhos de acordo com a topografia natural da área. O arranjo escolhido buscava alcançar um efeito pitoresco, seguindo princípios da teoria paisagística estabelecidos naquele momento. Ainda, como forma de reforçar o apelo natural do lugar, Bigelow decidiu por utilizar o nome de espécies de árvores e plantas conhecidas da região para designar os caminhos e avenidas do cemitério. Assim, o Mount Auburn foi construído de modo a suavizar a relação com a morte e induzir seus visitantes a um estado reflexivo que visava funcionar como um lembrete da mortalidade humana.

14

Usualmente conhecidos como cemitérios rurais, a opção pelo termo cemitério campestre foi feita de modo a enfatizar o conteúdo por trás dos aspectos desses espaços. Com isso, pretende-se reforçar a noção de campo como algo bucólico, diferente do campo rural, que hoje tem seu sentido carregado pela questão agrária. 
A solução apresentada pelo Mount Auburn representou uma grande mudança no cenário dos cemitérios estadunidenses. Logo após sua abertura, o cemitério atraiu tantos visitantes que as estradas para o local ficavam lotadas de carruagens. Em algumas situações, o número de visitantes chegava a ser tão grande que foi preciso limitar as visitas apenas aos proprietários e convidados (SCHUYLER, 1986). A partir do exemplo bem-sucedido de Boston, outras cidades começaram a estudar locais para instalar seus próprios cemitérios campestres. Na Filadélfia, John Jay Smith liderou a fundação do Cemitério Laurel Hill, em 1835. Em Nova Iorque, foi estabelecido o Cemitério Green-Wood, no Brooklyn, em 1838. Esses três locais conformam o chamado "triunvirato dos primeiros e mais influentes cemitérios campestres dos Estados Unidos", de acordo com David Schuyler (1986, p.45, tradução nossa). A partir da experiência destas três cidades, a ideia de estabelecer cemitérios campestres se espalhou pelo país, levando à fundação de diversos lugares que seguiram preceitos similares ao Mount Auburn.
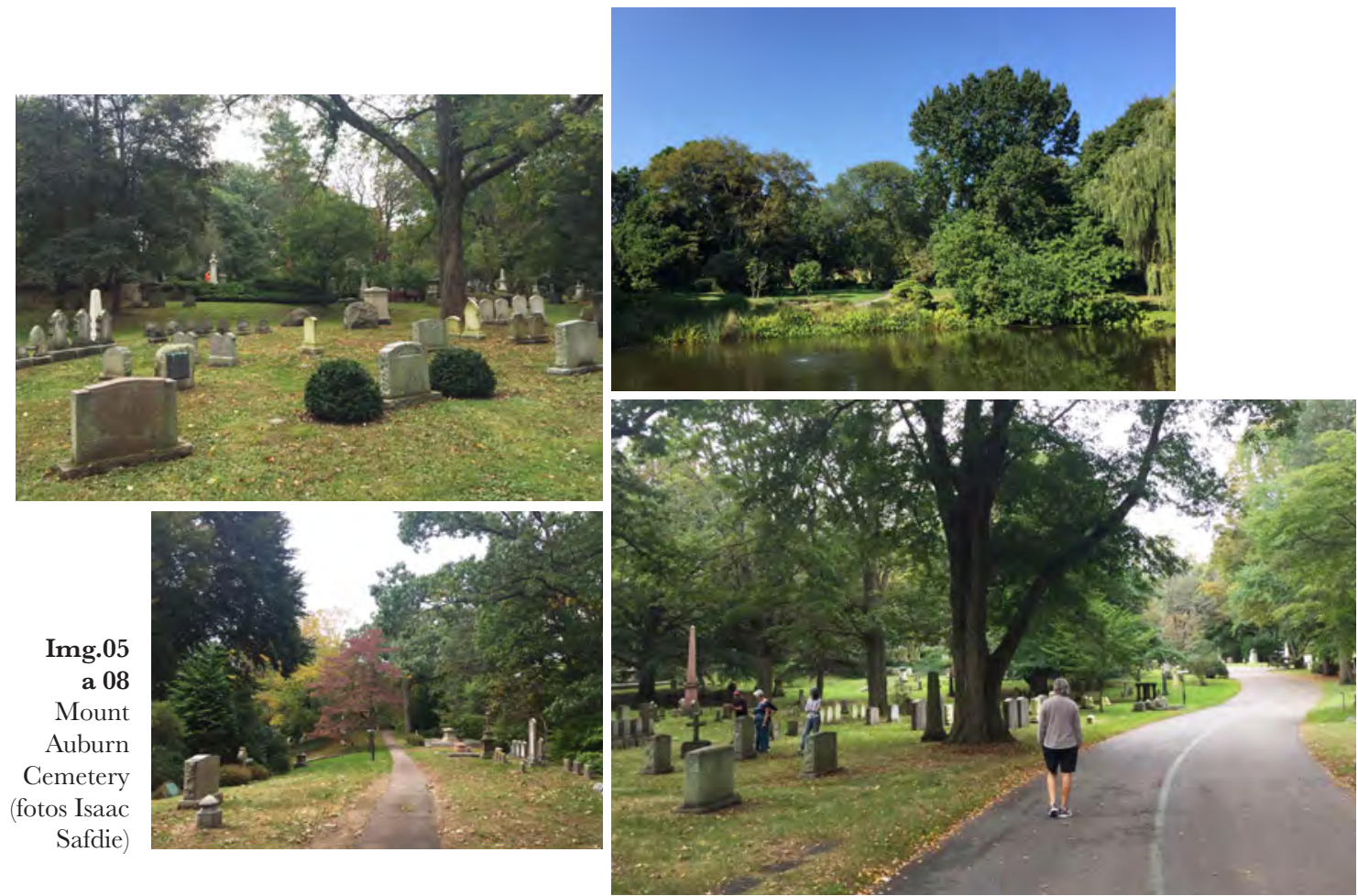
O cemitério campestre se tornou então uma importante instituição urbana nos Estados Unidos. Nesse sentido, Schuyler (1986) defende que os cemitérios campestres foram a expressão física determinante para o desenvolvimento da forma e da cultura urbana dos Estados Unidos a partir do século XIX. Eles foram os primeiros grandes espaços planejados paisagisticamente e com grande presença de vegetação que estavam abertos a visitas públicas, ou seja, ao alcance de toda população. Embora no início a justificativa para a criação desses lugares tenha sido uma preocupação com a saúde pública e a inadequação de cemitérios junto ao centro urbano, os cemitérios campestres se tornaram verdadeiros retiros para os habitantes da cidade industrial, contrastando a organicidade da paisagem natural com as linhas retas da cidade ortogonal. Esses lugares tiveram, portanto, um papel que ultrapassou a questão fúnebre, gerando impactos também do ponto de vista sociourbano.

Andrew Jackson Downing, figura considerada pioneira dentro do paisagismo estadunidense, propagava a ideia de que os cemitérios campestres foram os primeiros jardins e esplanadas públicas realmente elegantes dos Estados Unidos (SCHUYLER, 1986). Downing percebeu que, devido à ausência de espaços de remanso nas grandes cidades, muitos moradores iam a esses lugares para escapar da atmosfera carregada do ambiente urbano, buscando obter ar fresco e entrar em contato com a natureza. Assim, o cemitério, que havia sido pensado como um lugar de repouso, isolamento e paz estava se tornando um lugar para quem buscava apenas se entreter e passear. Downing demonstrava certa preocupação com essa utilização dos espaços de cemitério pois, para ele, havia certa incongruência entre o cemitério e um lugar de recreação. Ele entendia que as pessoas que iam a esses locais deveriam se dedicar somente às lembranças solenes (DOWNING, 1849 apud SCHUYLER, 1986).

Tendo em vista essa conjuntura, ganharam espaço dois movimentos: um que argumentava sobre os benefícios da aproximação com uma natureza domesticada, que podia e devia ser pensada de modo planejado; e outro que defendia a criação de parques públicos, com o intuito de oferecer espaços onde ambientes naturais poderiam ser reproduzidos e vivenciados dentro do meio urbano (FRANCIS, 2003). Assim, impulsionada pela boa receptividade dos 
cemitérios campestres, a ideia de que grandes extensões de beleza natural eram essenciais para a melhoria da qualidade de saúde e da vitalidade da população urbana passou a ganhar cada vez mais adeptos. Desse modo, a partir do êxito dos cemitérios campestres e da vasta utilização de seus espaços, não tardou para que os governos municipais agissem de modo a fornecer parques exclusivamente destinados ao uso contemplativo e recreativo. Essa passagem do cemitério para o parque marcou a mudança de uma paisagem pensada de forma instrutiva em relação à natureza, para o naturalismo dos primeiros parques dos Estados Unidos. As diferenças entre cemitérios ornamentais e instalações recreativas exigiram uma reformulação do uso do cenário natural, de uma perspectiva que buscava promover uma contemplação moral da natureza, para uma paisagem que em sua própria rusticidade seria um antídoto para as condições de vida dentro das cidades (SCHUYLER, 1986).

Assim, ao retomar a constituição dos parques no contexto estadunidense, focando na reflexão a respeito da influência dos cemitérios nesse processo, é possível levantar alguns aspectos que irão contribuir para pensar a respeito da evolução da configuração dos espaços de cemitérios. Por exemplo, ao se pensar nos conhecidos cemitérios-jardim ${ }^{15}$ que encontramos hoje, pode-se imaginar que estes locais tiveram forte influência dos ambientes de parques, como se tivessem sido derivados destes últimos. Porém, ao se aprofundar na história de formação desses locais, constata-se que esse processo é bastante dialético. Muitos cemitérios antecederam os parques como lugares abertos ao público e que permitiam o acesso da população a ambientes de grande presença de elementos naturais. O estudo da experiência dos cemitérios campestres mostra que o usufruto dos seus espaços surge como uma questão que vai além do tema de destinação dos corpos e se apresenta como uma questão a respeito da apropriação daqueles espaços em uma perspectiva de busca por uma melhor qualidade urbana, tanto do ponto de vista ambiental-natural, como no aspecto contemplativo-recreativo.

15

Apesar de no Brasil não haver uma distinção clara entre o que é chamado de cemitério-jardim e de cemitério-parque, este trabalho adota o termo cemitério-jardim como meio de indicar que, majoritariamente, estes locais estão mais relacionados à ideia de contemplação e de cultivo do jardim do que à ideia de convívio e recreação associada ao parque. 


\section{Cemitérios gramados}

Ao mesmo tempo em que os cemitérios campestres encontraram adeptos e tornaram-se bem-sucedidos como modelo para os cemitérios estadunidenses, outros segmentos da sociedade consideraram estes lugares demasiado ornamentados e sentimentais ou ainda muito caros, o que os tornava inacessíveis. Assim, em 1855, os administradores do Cemitério Spring Grove, de Cincinnati, decidiram por rever alguns aspectos da configuração do local, inicialmente pensados nos moldes de um cemitério campestre. O arquiteto paisagista Adolph Strauch foi quem conduziu o processo de reconfiguração do local. Ele teve como base não apenas eliminar características tipicamente associadas aos cemitérios rurais, como também criar uma nova forma que deveria refletir e articular um conjunto diferente de necessidades e valores.

Strauch criou então um cemitério de formalidade mais simples, com espaços mais abertos e com menos vegetação. As áreas de enterro foram diminuídas e os espaços de sepultamento padronizados e nivelados a grandes gramados que passaram a ser o símbolo do semblante do local, chamado então de lawn cemetery - cemitério gramado. Nestes gramados, foram suprimidos os monumentos e construções tumulares, que foram substituídos por pequenas placas colocadas no chão. A partir da influência do botânico e paisagista John Claudius Loudon, foram plantados apenas coníferas e folhas persistentes. Desse modo, a estética geral do cemitério gramado era menos naturalista, como oposição ao cemitério campestre, e mais cultivada, tendo a noção de modicidade na forma de configurar o espaço. Essa postura não teve como intuito simplesmente retirar toda e qualquer ornamentação, mas suprimir elementos que trouxessem uma sensação de tristeza ou dor (SLOANE, 1995).

Outro aspecto trazido pelo cemitério gramado foi a forma de gestão destes locais. Strauch entendia que era preciso ir além da constituição do espaço. Como meio de garantir sua manutenção, era necessário estabelecer um gerenciamento contínuo. Assim, o cemitério passou a se apresentar como um empreendimento comercial, seguindo inclusive práticas profissionais do setor de vendas de imóveis. A responsabilidade pelo processo foi transferida para uma nova geração de profissionais do cemitério, sendo necessário, a partir de então, apenas adquirir um pacote de serviços baseado na ideia de cuidado perpétuo. $\mathrm{O}$ novo cemitério gramado foi pensado de modo a negar os processos do tempo ou a paisagem das ruínas que os locais de sepultamento tradicionalmente simbolizavam (SLOANE, 1995). 
Apesar de ser alvo de constantes críticas e de ter sido em grande parte rejeitado em outros contextos como a Europa, o cemitério gramado se estabeleceu como uma parte genuína da cultura funerária estadunidense. Assim, embora os cemitérios gramados não tenham conquistado o imaginário das pessoas como seu precursor, o cemitério campestre, eles rapidamente se expandiram, sendo um dos tipos mais comuns de cemitério nos Estados Unidos. Com isso em mente, o historiador de arquitetura Marc Treib (1994) sugere que é preciso reconhecer algumas de suas realizações. Ele destaca que seu modelo de gestão consolidou a importância de se pensar sobre a manutenção desses lugares, de modo a evitar que o cemitério seja abandonado ou negligenciado.

\section{Cemitérios vitorianos}

No início do século XIX, Londres começou a passar por um grande crescimento populacional que levou à falta de espaços de enterro na cidade. Buscando solucionar essa demanda, o parlamento inglês aprovou um projeto de lei em favor do estabelecimento de um conjunto de cemitérios ao redor de Londres em 1832. Chamados posteriormente de os sete magníficos ${ }^{16}$, esses cemitérios criados na Era Vitoriana tiveram como referência o modelo do Père-Lachaise, que a essa altura já era prestigiado no mundo ocidental.

O mesmo Loudon que influenciou o surgimento dos cemitérios gramados foi figura fundamental para a conformação dos cemitérios vitorianos, fundando o que James Stevens Curl (2008) chamou de movimento de cemitérios-jardim. Loudon se opunha aos cemitérios eclesiásticos e sua configuração conturbada. Ele acreditava que o cemitério deveria ser projetado tendo como principal objetivo a devida organização e setorização dos espaços. Ele acreditava que esses locais deveriam ter um caráter de paisagem distinto, que o tornassem reconhecíveis como um cemitério imediatamente, em grande parte por meio de formalidade de suas avenidas e ruas. Loudon visualizava o espaço de cemitério como um arboreto, um local propício para o cultivo de variadas espécies botânicas. Desse modo, não apenas os túmulos deveriam ser identificados, mas as árvores, arbustos e outras plantas também deveriam ser nomeados, tornando o cemitério uma modelo de instrução em arquitetura,

16

Em 1981, o historiador de arquitetura Hugh Meller denominou esse grupo de cemitérios vitorianos de The magnificent seven, lembrando o filme de faroeste de mesmo nome. 
escultura, jardinagem paisagística e botânica. Quanto ao plantio de árvores, ele defendia principalmente o uso de coníferas do tipo fastigiado, como o cipreste, além de preferir o uso de espécies de folha persistente. Ele acreditava que essas espécies traziam uma expressão de solenidade e grandeza fundamental para a ambiência do local (CURL, 2008). Assim, buscava criar um estado de tranquilidade e repouso pelo uso de vegetação no cemitério de uma forma diferente da usada em outros lugares.

Loudon tinha uma visão bastante pragmática, preocupado inclusive com o futuro desses lugares. Para ele, quanto maior fosse o número de cemitérios, maior seria o número de futuros jardins públicos. Ele defendia que, à medida que fossem ficando saturados e cessassem os enterros, os cemitérios deveriam ser transformados em passeios públicos ou jardins. Assim, percebe-se que Loudon pensava os cemitérios como espaços que funcionam para além da colocação dos mortos, mas como lugar a ser usufruído também pelos vivos. Apesar de não ter projetado muitos cemitérios, seus escritos foram fundamentais para a configuração dos cemitérios vitorianos. Em relação à influência desses espaços em outros lugares, destaca-se o seu legado principalmente em relação ao uso de espécies de vegetação como as coníferas e as folhas perenes, que até hoje são associadas aos espaços de cemitério.

Os cemitérios vitorianos alcançaram o ápice de sua popularidade na segunda metade do século XIX. Com a chegada do século XX, esses locais não apenas começaram a ficar saturados, como houve o crescimento do uso da cremação na Inglaterra que contribui para seu declínio. Atualmente, alguns desses lugares, mais notavelmente o Highgate Cemetery, são centro turísticos de visitação. Outros deles, como coloca Worpole (2003) tornaram-se refúgios para a proliferação de fauna e flora próximas ao meio urbano, configurando-se além de espaço memorial, como uma espécie de reserva ambiental.

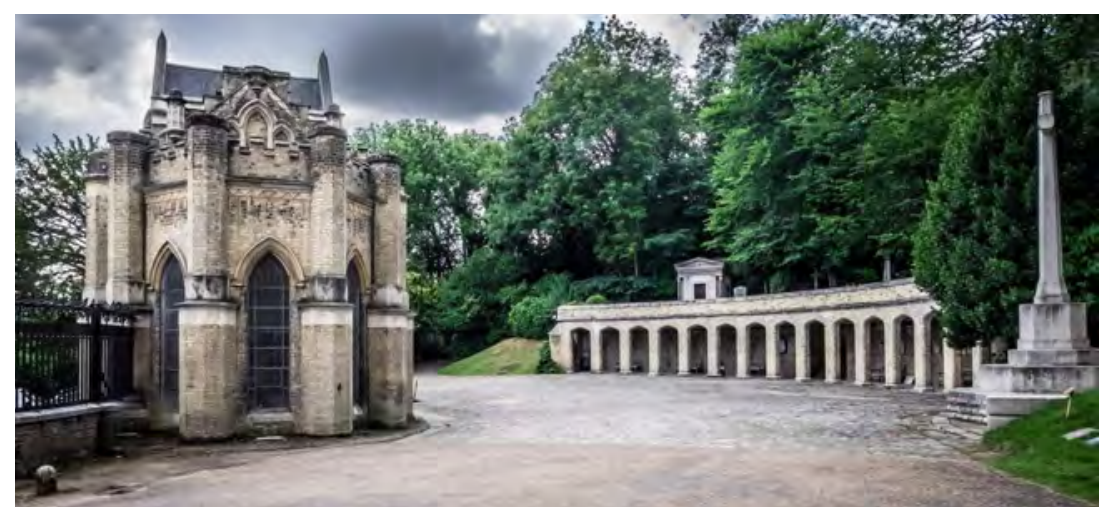

Img.09

Highgate

Cemetery

(magx.com) 


\section{Expansão}

Até aqui foi apresentado um contexto geral a respeito dos cemitérios ocidentais para na sequência discutir importantes matrizes de sua consolidação. Assim dito, viu-se como esses lugares se desenvolveram atrelados a questões e padrões sociais e econômicos vigentes em cada momento. No entanto, ao analisar de forma mais minuciosa, de acordo com a região em que está situado, é possível encontrar algumas diferenças na trajetória desses espaços que são determinantes na definição espacial dos cemitérios. De forma bastante sucinta, percebe-se que na América do Norte, Reino Unido e em boa parte do norte da Europa houve uma maior diferenciação em relação à França, Espanha, Portugal e Itália. A maior divergência entre esses dois grupos de países não se dá nem no protocolo dos funerais, nem nos hábitos de luto, mas na arte dos túmulos e, consequentemente, nos espaços de cemitério. A princípio, pode parecer que esta distinção é decorrente somente das divergências entre o protestantismo e o catolicismo desses lugares, no entanto, outros fatores contribuem para essa condição. Ariès (2010) ressalta o papel da questão 
religiosa nesse aspecto, principalmente ao se verificar que no decorrer do século XIX o catolicismo desenvolveu expressões sentimentais e emocionais próximas a um neobarroquismo romântico, ainda assim, não se deve esquecer que o carácter simbólico e emocional do culto dos mortos não é de origem cristã, mas foi estruturado através de ideias iluministas vigentes no período. Portanto, Ariès (2010) defende que a questão socioeconômica de cada local também tem seu papel. Para ele, as atitudes funerárias neobarrocas desenvolveram-se nas culturas em que a influência do campo teve maior resistência e não foi anulada pelo crescimento econômico que caminhou de modo mais lento. Dessa forma, além da vertente religiosa, a taxa de industrialização e de urbanização de cada lugar pode ter sua influência nesse processo de diferenciação.

Assim, na prática, o que ocorre é que países como Reino Unido e Estados Unidos adotaram o caminho de um tipo de cemitério ligado à ideia de natureza. De forma geral, os túmulos eram concebidos como parte de um ambiente que deveria ser paisagisticamente capaz de estabelecer um sentido moral pela presença de árvores, jardins e plantas, como visto nos exemplos descritos anteriormente. Desse modo, à exceção de mortos ilustres, os túmulos eram concebidos de forma menos monumental, buscando uma postura de maior simplicidade frente à morte. No entanto, ao contrário do que pode parecer, esse gesto não implicava falta de afeto, mas adaptava-se à uma melancolia de culto romântico dos mortos. caminho, rapidamente passaram a incorporar estátuas e monumentos às sepulturas. Os cemitérios desses lugares começaram então a se caracterizar pela presença de construções funerárias mais elaboradas, marcando a paisagem de uma forma mais pronunciada e configurando o imaginário fúnebre a respeito dos espaços de cemitério até hoje. De início, nesses lugares houve uma menor variação na tipologia de cemitérios $^{17}$, estabelecendo de forma majoritária o modelo chamado aqui de cemitério tradicional. 
Bastante subordinada aos costumes portugueses e franceses de modo geral, a sociedade brasileira à época acabou influenciada diretamente por esta segunda concepção. Os costumes cristãos, mais especificamente, os católicos, foram por séculos os únicos oficialmente permitidos, balizando os costumes funerários nas cidades brasileiras (GYMBALISTA, 2002). No Brasil, o processo de condução dos enterros pelas Igrejas passou a ser colocado em cheque através de Carta Régia assinada pelo príncipe regente em 1801. A carta recomendava aos governadores das províncias que adotassem a proibição dos sepultamentos no solo das igrejas e sugeria a construção de cemitérios distanciados das aglomerações urbanas. A recomendação passou a ganhar efetividade apenas algumas décadas depois, durante o reinado de Dom Pedro I, através da aplicação de uma lei promulgada pelo imperador em $1^{\circ}$ de outubro de 1828 (LOUREIRO, 1976). A partir de então, começou a ser colocada em prática a construção dos primeiros cemitérios brasileiros.

Apesar da presença de alguns movimentos contrários às mudanças $^{18}$, a resolução ganhou espaço à época, configurando-se como uma questão de ordem pública que resultou no encaminhamento do assunto às câmaras municipais, herança guardada até os dias de hoje. Desse modo, também no contexto brasileiro, os cemitérios públicos se apresentaram não apenas como uma solução às questões de ordem médica, mas como uma resposta urbanística à problemática da morte nas cidades, definindo para os mortos um lugar dentro do organismo urbano. (CYMBALISTA, 2002). Como conta Ariès (2010, p.150): "dizia-se no século XVIII: nada de cidades com cemitérios, dir-se-á no fim do século XIX: sem cemitérios, não há cidades".

Assim, a partir do entendimento da importância fundamental dos cemitérios, diversos municípios começaram a discutir sobre a implementação destes lugares. Especificamente em São Paulo, o debate sobre o tema se iniciou no final da década de 1820, através de um longo processo que culminou na abertura do primeiro cemitério público oficial da cidade, em 1858.
18

Destaque para o movimento ocorrido na Bahia que ficou conhecido como Cemiterada, que foi configurada por um movimento amplo da população que se recusava a deixar que um aspecto tão importante como a morte fosse gerido por empresas no lugar das instituições religiosas. Para mais, ver João José Reis, $A$ morte é uma festa, 1991. 


\section{Assimetria perante a morte}

Até a abertura dos cemitérios públicos, devido às restrições religiosas existentes para os enterros nas igrejas, todos aqueles que não eram católicos encontravam-se em uma situação desfavorável frente à morte. Este cenário era comum não apenas àqueles mais vulneráveis socialmente, como escravos e condenados, mas também para adeptos de outras variantes do cristianismo, como o protestantismo. Essas pessoas eram destinadas aos chamados cemitérios a céu aberto, que serviam então como símbolo da distinção religiosa daquele tempo. São Paulo tinha o seu cemitério a céu aberto desde a década de 1770, conhecido como Cemitério dos Aflitos ${ }^{19}$. Localizado no atual bairro da Liberdade, ele deixou de existir a partir de 1858, com o estabelecimento do primeiro cemitério público da cidade $^{20}$, o Cemitério Consolação.

Como visto em (3) Revolução Cemiterial, o surgimento do cemitério público foi decorrente do fortalecimento de preceitos higienistas e sanitaristas que fizeram com que a

Cf. em Formas de bem morrer em São Paulo: transformações nos costumes fúnebres e a construção do cemitério da Consolação (1801-1858).

Dissertação de Mestrado em História na Universidade de São Paulo: São Paulo, Breno Matrangolo. responsabilidade dos enterros saísse do domínio das igrejas e fosse encaminhada para o âmbito Estatal. Assim, além da construção desses locais ter sido assumida pela administração pública, também a responsabilidade sobre a fiscalização, a manutenção e a prestação dos serviços fúnebres se consolidou no âmbito dos serviços públicos, ficando a cargo de cada município desenvolver regulamentações sobre o tema. Em virtude da importância das questões de saúde e ordem pública na época, determinou-se por lei que os valores dos serviços fúnebres deveriam obedecer aos princípios de modicidade ou, em caso de falta de recursos, ser custeado pelo município. Ainda, em meio ao contexto de secularização e à condição pública do cemitério, ele deveria se configurar como espaço laico, acolhendo então todo e qualquer tipo de religião, grupo étnico ou posição social. Essa nova conjuntura não tardou a incomodar entidades religiosas e grupos da alta sociedade, que aos poucos foram encontrando em 1935 meios de reafirmar sua hegemonia. 
Desse modo, apesar de oficialmente laico, o cemitério viu o próprio Poder Público autorizar a construção de uma capela católica em seus espaços, tendo como justificativa atender a demanda de uma população muito ligada aos velhos costumes. Os preceitos do catolicismo mantiveram-se, então, preponderantes, em contraste com a pouca representatividade de outros tipos de crença.

Quanto à questão social, aos poucos, as classes mais altas passaram a implementar construções e monumentos fúnebres exuberantes, dedicados a grandiosidade de seus mortos, enquanto que as classes mais pobres se limitavam a construir sepulturas simples e usar pequenos artefatos. Através da caracterização das expressões funerárias, os grupos dominantes conseguiam se diferenciar daqueles que consideravam menos dignos, encontrando assim forma "mediação pública do problema" (CYMBALISTA, 2002, p.64). Ter um túmulo bem localizado e com construções tumulares suntuosas passou ser sinônimo de prestígio e relevância, exaltando os poderes econômicos do indivíduo ou da família em questão. O espaço dos primeiros cemitérios passou então por um processo de elitização, estabelecendo uma configuração que é marcada pela expressividade dessas representações e pela ocupação desigual dos espaços. Estes locais, marcados pela grande presença de construções tumulares ficaram conhecidos como cemitérios tradicionais ou oitocentistas, como referência ao seu período de formação.

Ainda em relação a conformação dos cemitérios, ao fazer uma associação entre a estruturação destes locais e a cidade, Louis-Vincent Thomas observou:

"Não é singular que a configuração das cidades se pareça tanto com a dos cemitérios? A ordenação de uma e de outra obedece ao mesmo enquadramento geométrico e a repartição dos elementos responde a questões similares. Habitat individual e coletivo, ruas, avenidas, praças onde a circulação é regulamentada, bairros aristocráticos ou populares, lugares de descarga, cartazes e tabuletas, tudo isso se encontra nas aglomerações dos vivos e dos mortos, em escalas variáveis segundo suas populações. Mesmo os grandes cemitérios, como as grandes metrópoles têm seus arranha-céus, suas torres de silêncio, ou as terão, para conciliar o crescimento do número e a penúria do espaço...”

(THOMAS, 1976, p.191, tradução nossa) 
Percebe-se, através da colocação de Thomas, como a organização espacial dos cemitérios apresenta muitas semelhanças à ordenação da cidade. Isso ocorre não apenas num sentido formal, mas também na forma de ocupação e regulação. Desse modo, o cemitério pode ser entendido como um lugar de reprodução simbólica do universo social em que está inserido. Como destaca Catroga, "o cemitério revela esteticamente o próprio inconsciente da sociedade através de uma trama simbólica, estruturada e organizada à volta de certos temas e mitos unificados por esta tarefa" (2010, p.170). Assim, ao reproduzir em seus espaços os traços de uma sociedade desigual, o cemitério, como um espelho da cidade, torna-se este espaço marcado por uma ocupação dessemelhante. Como destaca Cymbalista,

“... a universalidade do direito à morte ocorre sob uma fôrma específica, branca, europeia e que se considerava civilizada, em contraponto a tudo o que era diferente dela. O cemitério é 'para todos', desde que seja sob as regras de alguns. E o cemitério foi um dos locais escolhidos pela parte 'civilizada' da sociedade para tornar 'verdadeira' a sua visão do mundo, criando como pôde uma teatralidade burguesa e inspirada nos já conhecidos cemitérios urbanos europeus..."

(CYMBALISTA, 2002, p.73)

Portanto, se do ponto de vista urbanístico o cemitério representou grandes transformações através da consolidação de gestão da morte em um território segregado, do ponto de vista dos costumes privados a secularização não vingou com a mesma velocidade (CYMBALISTA, 2002). Ao entrar nesses locais, percebese facilmente a predominância de uma religiosidade específica, caracterizando o cemitério público como um espaço laico apenas em teoria. Se no passado a diferenciação foi garantida pela ordem eclesiástica, neste período ela foi sustentada pelo próprio Estado que não apenas permitiu mas também legitimou esse processo. Essa condição assimétrica indica a distância que continuou a existir entre o suposto direito de todos à sobrevivência individualizada e a possibilidade de imortalização na memória coletiva. Efetivamente, as hierarquias sociais entre os vivos construíram uma análoga desigualdade no acesso à construção de uma memória duradoura e na sua representação, como coloca Catroga: 


\begin{abstract}
"Nos nossos cemitérios [do mundo ocidental] do século XIX, o mausoléu, o jazigo-capela e a concessão perpétua constituíam um patrimônio, de certo modo privado e transmissível como qualquer outro, que funcionava como uma espécie de prova última segundo a qual a eternização da memória do proprietário (logo, de toda a linhagem familiar) ficava dependente da capacidade que os seus descendentes teriam para a perpetuar.”
\end{abstract}

(CATROGA, 2010, p.177)

Partindo desse entendimento, é possível desenvolver alguns aspectos trazidos pelo filósofo e sociólogo Jean Baudrillard que ajudam a refletir sobre a condição de desigualdade perante a morte. Usando do conceito de imortalidade, Baudrillard defende que ao mesmo tempo que o deslocamento dos mortos dos centros urbanos ganha lugar, torna-se mais amplo o conceito de imortalidade. Para ele, esse é o conceito-chave que recobre a ruptura da "troca simbólica" com eles (1996, p.174). Quando estão próximos aos vivos, os mortos não têm necessidade de serem imortais, porque isso abalaria toda a reciprocidade da sua relação. É a partir do afastamento dos mortos que lhes é concedida a imortalidade, que o autor define como um conceito progressivo no tempo e no espaço social: ele passa de uma sobrevivência limitada à sobrevivência eterna. Para melhor entender esse processo, é possível pensar no Egito antigo, onde apenas membros da alta hierarquia se distinguiam como imortais, ganhando construções grandiosas como as pirâmides para demarcar essa condição. É com o passar dos tempos que a ideia de imortalidade é expandida e passa de privilégio de alguns a direito virtual de todos, algo que é relativamente recente na história (BAUDRILLARD, 1996).

Portanto, a partir da perspectiva de Baudrillard, a imortalidade se "popularizou", podendo ser entendida como uma espécie de conquista social. Assim, na origem emblemática do poder, a imortalidade da alma funciona, ao longo do cristianismo, como uma espécie de "mito igualitarista, como democracia do além diante da desigualdade mundana perante a morte" (BAUDRILLARD, 1996, p.175). No entanto, efetivamente, ela permanece no interior de uma certa casta social, demarcando as relações entre morte e poder. Como provoca Baudrillard: "os missionários terão algum dia acreditado na alma imortal dos indígenas? A mulher tinha de fato alma no cristianismo 'clássico'? E os loucos, as crianças, os criminosos? Com efeito, voltamos sempre ao mesmo ponto: só os poderosos e ricos têm alma." (1996, p.176). 
Seguindo esse raciocínio, a desigualdade diante da morte, seja ela social, política ou econômica se configura como sintoma de uma discriminação fundamental onde apenas alguns grupos têm direito à imortalidade, enquanto outros o têm somente à morte. Baudrillard se posiciona de forma veemente a respeito dessa lógica:

\footnotetext{
"Vemos também que a democracia nada altera aqui. Foi possível ao homem obter a imortalidade da alma para todos, assim como gerações proletárias lutaram para obter a igualdade dos bens e da cultura. Mesmo combate, uns pela sobrevivência do além e os outros pela atual sobrevivência, mesma emboscada: sendo a imortalidade de alguns resultante da segregação social, de que serve reivindicá-la para todos? Trata-se apenas de generalizar o imaginário. A revolução só pode consistir na abolição da separação da morte, e não na igualdade da sobrevivência."
}

(BAUDRILLARD, 1996, p.176)

Desse modo, de um ponto de vista social, apesar do cemitério público tradicional representar um avanço em relação ao cemitério eclesiástico e ao cemitério a céu aberto, no fundo, ele seguiu apresentando um desequilíbrio entre a morte elitizada das classes altas e a morte popular das classes baixas.

\section{Contratempos}

O constante aumento populacional da cidade de São Paulo ao longo do século XX acabou expondo a necessidade de se criar espaços de sepultamento para abrigar o número crescente de óbitos. Assim, na busca por áreas disponíveis, novos cemitérios foram sendo estabelecidos em locais cada vez mais afastados e, em muitos casos, de difícil acesso. Esse fator, somado às mudanças recorrentes na dinâmica de uma cidade extensa, fez com que os cemitérios ficassem cada vez mais distantes dos familiares e amigos, levando ao enfraquecimento do culto aos mortos. Esse tipo de conduta foi se intensificado com o passar dos anos, fazendo com que os túmulos ficassem desamparados. Com isso, o espaço de cemitério foi se tornando negligenciado, passando a ser marcado por um semblante de deserção. 
Considerando que esse enfraquecimento na visitação e na percepção dos cemitérios se deu ao longo do século XX, é curioso pensar como o modernismo ${ }^{21}$, que alterou tão profundamente os rumos da arquitetura, pouco se dedicou a questão da arquitetura e do urbanismo funerários ${ }^{22}$. Autores como Edwin Heathcote pontuam que "o modernismo sempre teve um intenso e profundo problema com a arquitetura funerária" (1999, p.12, tradução nossa). Worpole (2003) coloca que as dificuldades enfrentadas por arquitetos modernistas em responder à questão da morte podem ter origem no impacto que as guerras e a cremação tiveram na Europa no século XX. Elas trouxeram o desafio de articular uma visão de morte menos atrelada à ideia do corpo, o que acabou por ser um tema semanticamente pouco trabalhado. As raras manifestações modernistas sobre o assunto seguiram uma lógica racional e funcionalista, que muitas vezes se manteve distante das práticas e rituais cotidianos. Em grande parte, as contribuições modernistas se limitaram ao advento de jardins formalmente ordenados, à geometrização de artefatos fúnebres como ossários ou columbários e ao projeto de edifícios funerários extremamente pragmáticos. Como lembra Worpole, mesmo os elementos construtivos da arquitetura modernista, especialmente o concreto, o aço e o vidro, parecem inadequados a uma tradição em que a terra, a pedra e a madeira tornaram-se os principais materiais.

Dessa forma, em relação à percepção e à construção dos espaços de cemitérios em si, o modelo estabelecido pelo Père-Lachaise no começo do século XIX seguiu dominante. No entanto, mesmo as teorias científicas tendo progredido e comprovado que os pretensos perigos da vizinhança dos cemitérios eram ilusórios, a rejeição aos mortos seguiu no imaginário social. Manteve-se, então, a segregação entre vivos e mortos, porém sob novos moldes. Ao serem alcançados pela expansão urbana, os cemitérios se configuraram como territórios fechados, cercados por grandes muros e sem interação com seu entorno. A esse respeito, os arquitetos e urbanistas do período pouco se dedicaram, restringindo-se a tratar o tema sob uma ótica de uso e desempenho do espaço.

21

Ressalta-se a diferenciação entre o adjetivo moderno e o termo modernista, referente ao conjunto de movimentos culturais, escolas e estilos que permearam as artes, a arquitetura e o durante boa parte do século XX.

22

Destaca-se como exceção os suecos Gunnar Asplund e Sigurd Lewerentz, que em 1914-15 desenvolveram o projeto do chamado Skogskyrkogården (cemitério da floresta), que será mais detalhado no tópico (13) Perspectivas. 
Em São Paulo, um exemplo é o caso do Cemitério do Araçá, objeto de proposta do arquiteto Jorge Wilheim na década de 1960. Por estar localizado em uma região privilegiada da capital, o arquiteto Jorge Wilheim (1982) propôs que os restos mortais existentes no local fossem transferidos para um cemitério vertical a ser construído em lugar mais afastado do centro. $\mathrm{O}$ argumento principal para a mudança era o "desperdício" em utilizar para enterros uma área valorizada da cidade, desse modo, o terreno do atual cemitério seria "liberado" para a implantação de um centro cultural. Outro arquiteto paulista, Fábio Penteado, também concebeu proposta similar, sugerindo que terrenos de cemitérios como o Araçá e o Consolação poderiam ser utilizados para o usufruto dos paulistanos. Seguindo a mesma linha de pensamento de Wilheim, Penteado (1998, p.121) defendeu que os cemitérios poderiam ser transferidos para "lugares mais adequados para isso, como os grandes espaços abertos nas montanhas que circundam a cidade".

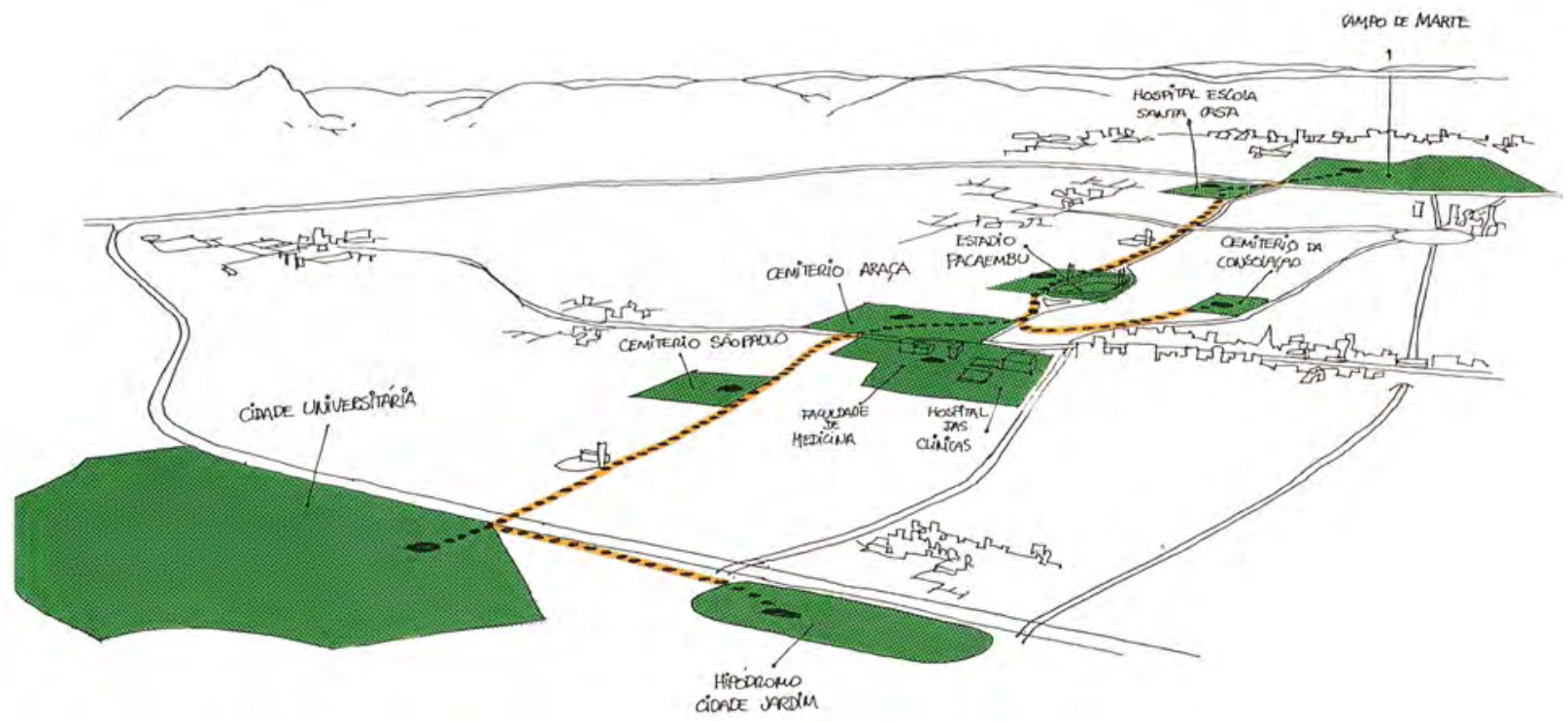

Img.10

Eixo Parques e Cemitérios de São Paulo

(Fábio Penteado) 
Percebe-se que, em ambos os casos, as propostas acabaram por reproduzir a ideia de deslocamento dos cemitérios para regiões menos adensadas, tendo em vista um "melhor" aproveitamento destes locais. Desse modo, o caminho da transferência dos espaços de cemitério segue o mesmo itinerário de escamoteamento da morte do movimento de transferência dos cemitérios eclesiásticos. No entanto, se no século XIX o distanciamento é defendido a partir de um viés higienista, no século XX ele é justificado através da percepção de que as terras urbanas ocupadas pelos cemitérios constituem um desperdício (ZIEGLER, 1977). Assim, essas abordagens, por mais bem-intencionadas que sejam, acabam por se enquadrar em um discurso mercadológico de valorização fundiária, apresentando-se como saídas deterministas e reducionistas frente à problemática da morte.

Nesse sentido, Worpole (2003) destaca que para se realizar uma discussão dos espaços de cemitérios será preciso organizar as bases e diretrizes de pesquisa, pois há uma grande lacuna de análise e pensamento sobre o tema decorrente da dificuldade de se dedicar ao assunto durante os últimos tempos. Ainda nesse sentido, percebe-se que a maior parte das pesquisas sobre esses locais costuma se dedicar mais à problemática das construções tumulares, e pouco aos aspectos conceituais e investigativos dos espaços de cemitério. Com isso em mente, mostra-se fundamental uma aproximação da arquitetura e do urbanismo com o tema, de modo a destrinchar os variados sentidos deste espaço, a serem vistos na sequência. 



\section{O Gemitério Público e o Cemitério Particular}

\section{$\underline{\text { O Cemitério Público }}$}

Além das dificuldades de deslocamento decorrentes da dinâmica de uma cidade grande como São Paulo, a passagem do tempo trouxe à tona um outro inconveniente para o cemitério: a falta de elo entre gerações distantes. A perda de contato com familiares falecidos de longa data fez com que os cemitérios mais antigos fossem menos frequentados. Assim, não apenas o desamparo aos cemitérios públicos aumentou, como começaram a surgir críticas à ideia de concessão perpétua. Ela passou a ser vista como uma questão problemática tanto do ponto de vista da demanda por novos espaços de enterros, como também pelos fatores de conservação e manutenção dos túmulos. Na prática, o modelo de concessão perpétua levou os cemitérios mais antigos à saturação das suas áreas de sepultura, o que trouxe críticas quanto à longevidade desse procedimento. Ao se realizar um rápido exercício mental pode-se perceber que uma forma de ocupação do espaço isolada e individual atual é insustentável a longo prazo, pois em dado momento, se todos tivessem o direito a ser enterrado nesses parâmetros, todo o planeta seria 
ocupado por locais de enterro ${ }^{23}$. Portanto, ao longo do tempo, foi necessário flexibilizar as condições de concessão, levando em conta fatores como a conservação e a demanda por espaços de enterro.

Desse modo, além das concessões perpétuas, os cemitérios públicos começaram a apresentar outras formas e meios de utilização dos seus espaços, como as concessões temporárias e a permissão de uso. No caso das concessões temporárias, os municípios devem determinar a remuneração e os prazos específicos através de legislação própria. Já a permissão de uso, também chamada de cova ou ainda quadra geral, é marcada pela necessidade de reutilização do espaço através do chamado sepultamento rotativo. Este procedimento é marcado por uma maior precariedade e por prazos menores, sendo utilizada apenas em cemitérios municipais de mais baixa renda. Nestes locais, após o prazo de três anos, o Município pode exumar o corpo enterrado que é destinado aos ossários presentes no cemitério.

Nesse sentido, apesar da ampliação ao direito de sepultamento a todos no século XIX através da ideia do jus

Considerando que uma unidade de enterro ocupa, em média, $5 \mathrm{~m}^{2}$, e que a superfície continental da Terra é de $150.200 .000 \mathrm{~km}^{2}$, tem-se um total de aproximadamente 30 trilhões de unidades de enterro, que dividas pela população da Terra de 7,53 bilhões (2018), chega a aproximadamente 4000. Ou seja, 4000 ciclos da população atual para que o planeta seja todo ele um cemitério.

24

Conforme incursão etnográfica realizada no $\mathrm{Ce}$ mitério da Vila Formosa, novembro de 2017. sepulchri, ao contrapor a morte elitizada de lugares como o Cemitério Consolação, a uma morte popular em locais como no Cemitério da Vila Formosa, percebe-se que as concessões perpétuas ficaram restringidas àqueles com condições de pagar o preço e as permissões rotativas restam como alternativa para os de mais baixa renda. Assim, determinou-se uma distinção social também em relação aos cemitérios em si, que começaram a ser vistos como espaços destinados a classes sociais específicas de acordo com sua localização e tipo de sepultamento. Ainda, ficou reservado às classes baixas a condição de ver o corpo de seus entes queridos decompostos (ou ainda em decomposição) devido à sua exumação após três anos. Esse procedimento é, em muitos casos, entendido como um evento traumático, algo que "traz más lembranças""24. Observa-se, então, que a distinção socioeconômica atua não apenas como barreira na definição da representação e da localização dos falecidos, mas também como um limitador temporal e protocolar dos sepultamentos. 
Ainda a respeito dos aspectos normativos de sepultamento, a noção do jus sepulchri assegurou, ao seu modo, não apenas o direito universal ao sepultamento, mas também garantiu a necessidade de se determinar locais específicos a esse fim (DA SILVA, 2000). Assim, retomando o tópico (3), a Revolução Cemiterial consolidou os primeiros importantes cemitérios do Brasil na esfera dos cemitérios públicos. Esses locais foram se expandido e se consolidando pelas várias cidades do país através da ação do Estado em relação às questões fúnebres, estando em grande parte vinculados ao Poder Público até os dias atuais (fevereiro de 2019). Desse modo, esses locais configuram-se como espaço públicos, sendo importante refletir sobre o significado dessa condição. Nesse sentido, destaca-se que o uso do termo cemitério público, tem como base o entendimento de cemitério como propriedade do Poder Público, fundamentado na ideia da posse de todos através do exercício de propriedade de uma área pelo Estado. No caso dos cemitérios públicos no Brasil, essa propriedade é exercida por cada município, sendo então esses locais chamados de cemitérios municipais. Em relação aos espaços de propriedade pública no Brasil, o Código Civil (BRASIL, 2002, Art. 99) organiza os bens públicos em três categorias: bens de uso comum do povo, bens de uso especial, e bens de uso dominicais ${ }^{25}$. No entanto, ao se pensar sobre os espaços de cemitérios municipais, pode-se encontrar alguma dificuldade frente essa classificação. Dentre as três divisões trazidas pelo Código Civil, o mais comum é considerar os cemitérios como bens de uso especial, no entanto, há algumas discordâncias a respeito. Assim, levando em conta as interpretações sobre a natureza jurídica dos cemitérios com base nas colocações do livro Tratado de direito funerário (2000), de Justino da Silva, foram desenvolvidas as seguintes ponderações sobre a classificação do cemitério junto às categorizações de bens públicos no Código Civil:

25 Segundo o artigo 99 do Código Civil brasileiro (2002), as propriedades públicas podem ser classificadas como bens de uso comum do povo (tais como rios, mares, estradas, ruas e praças), bens de uso especial (tais como edifícios ou terrenos destinados a serviço ou estabelecimento da administração federal, estadual, territorial ou municipal, inclusive os de suas autarquias) ou bens de uso dominicais (que constituem o patrimônio das pessoas jurídicas de direito público, como objeto de direito pessoal, ou real, de cada uma dessas entidades). 
1) Bem de uso comum do povo

Esta argumentação é baseada no fato de que os cemitérios são locais de acesso e utilização de toda comunidade, portanto não se enquadrariam como bens de uso especial. Ainda, por não terem como finalidade a produção de rendas para os municípios, também não poderiam ser considerados bens dominicais.

2) Cemitério como bem de uso especial

Ancorada na natureza do jus sepulchri, essa visão é a mais tradicional sobre cemitérios, sendo a mais passível de interpretação pelo Código Civil Brasileiro (2002) conforme citação anterior. Os defensores desse ponto de vista sustentam que a necessidade de concessão de parcelas do terreno para particulares impediria a caracterização do cemitério como bem de uso comum, fazendo com que sejam destinados ao cumprimento de uma função pública específica, no caso a realização de sepultamentos e a visitação por parte dos entes queridos.

\section{3) Cemitério como bem público dominical}

Esta visão é sustentada pela ideia de que o detentor do cemitério é o Município onde ele está localizado, associando esta condição a alçada patrimonial do direito privado. Assim, as municipalidades teriam poder de decisão sobre as questões do local, independentemente das outras instâncias de governo.

4) Cemitério como bem público de uso comum e especial (híbrido)

Posição que defende que os cemitérios apresentam elementos passíveis tanto a uma classificação como bem de uso comum do povo, como de bem de uso especial. Nessa perspectiva, defende-se que embora o cemitério tenha parcelas do terreno concedidas a entidades privadas, eles também são locais onde qualquer um pode transitar, colocando-os em uma condição híbrida. Ainda neste caso, refuta-se sua classificação como bem público dominical devido a finalidade não arrecadadora dos cemitérios. 
Assim, percebe-se que devido às especificidades dos espaços de cemitério municipais, a sua definição jurídica é objeto de controvérsias que permitem uma interpretação que vai além do Código Civil. Parte da explicação para a amplitude de interpretações do cemitério como bem público pode estar no reconhecimento de que eles são regidos tanto pelo direito público quanto pelo direito privado. Essa condição ocorre nos cemitérios municipais devido à condição de uso privado de parcelas e lotes de sepultamento em um terreno público através dos mecanismos de concessão e permissão vistos anteriormente. Dessa forma, devido à complexidade envolvida nestes processos, percebe-se como os cemitérios municipais se apresentam como uma espécie de organismo singular, com regras e condições próprias de funcionamento. Mesmo sendo bens públicos, eles permitem que se utilize um lote como uma espécie de imóvel particular que é, inclusive, transmitido de forma hereditária nos casos de concessões perpétuas. Nestes locais, as sepulturas, epitáfios ou qualquer outra manifestação fúnebre materializada representam as expressões privadas que são invariavelmente acessíveis e visíveis a todos devido à condição do cemitério municipal como espaço público. Assim, estes locais apresentam-se, de alguma forma, como públicos e privados simultaneamente, tanto do ponto de vista de ocupação do lugar, como de identificação da memória. Nesse sentido, a consideração de uma condição híbrida sobre a natureza dos bens cemitérios parece ser a forma mais razoável para se entender a dinâmica existente nestes espaços.

Desse modo, ao reconhecer essa condição, abre-se caminho para ampliar um debate sobre o cenário, as atribuições, as formas de uso dos cemitérios nas cidades brasileiras. Esse entendimento permite estender a limitação das finalidades estritamente fúnebres, possibilitando vislumbrar novas perspectivas amparadas por meios legais. Assim, o cemitério público pode ser pensado a partir de uma perspectiva que tenha em vista o proveito da população de forma abrangente, fortalecendo a noção de público não apenas no quesito de propriedade, mas também ao patamar do compartilhado e do social. 


\section{$\underline{\text { O Cemitério Particular }}$}

Os primeiros cemitérios particulares ou privados surgiram a partir de demandas e restrições religiosas impostas nos cemitérios públicos, fruto da dificuldade de aceitação do cemitério público como espaço laico. Ainda bastante ligados aos costumes da Igreja, os católicos manifestaram insatisfação com a vizinhança de outros grupos sociais e religiosos nos espaços de enterro. Desse modo, ainda no século XIX era possível encontrar cemitérios particulares pertencentes a grupos religiosos específicos, como os protestantes. Em algumas situações, os próprios municípios acabaram concedendo parcelas dos cemitérios públicos para este ou outros grupos religiosos específicos com algum poder de influência, de modo a amenizar os conflitos religiosos existentes. Com o passar dos anos, além desses cemitérios de cunho confessional, começou a ganhar espaço a presença de cemitérios em terrenos maiores, pensados desde o princípio com finalidades associadas a questões comerciais. A expansão desses lugares se deu principalmente a partir de meados do século XX, estando eles bastante consolidados no cenário urbano das grandes cidades brasileiras desde então.

O funcionamento de um terreno como cemitério se dá através da permissão de uso de áreas privadas para a prestação de serviços funerários, contanto que estes locais sejam objeto de fiscalização e regulação do Estado. Essas características seguem a Constituição de 1988, que atrelou a responsabilidade social ao direito de propriedade, fazendo com que o cemitério particular se enquadre na qualidade de espaço permissionário (DA SILVA, 2000). Assim, o cemitério particular é aquele cuja propriedade pertence a uma entidade privada, seja ela de uma ordem religiosa, uma instituição ou uma pessoa jurídica, e seu funcionamento está sujeito à permissão do Poder Público, representada pelas municipalidades. Por sua natureza privada, diferentemente dos cemitérios públicos, os cemitérios particulares podem ter caráter confessional. 
De forma geral, os cemitérios particulares oferecem lotes que ao serem adquiridos passam a ser propriedade privada e, portanto, um bem particular que é transmitido via herança ou por novo acordo financeiro. Em muitos casos, é comum que os lotes sejam comprados de forma antecipada, como meio de garantir a proximidade com os familiares mortos previamente. Em caso de não cumprimento do pagamento das taxas contratuais definidas inicialmente, o espaço retorna ao domínio do cemitério particular que pode vendê-lo novamente.

Em relação à frequentação dos cemitérios particulares, por serem locais de propriedade privada, eles podem ou não ser de acesso público. Nesse sentido, é importante ter clara a distinção entre o cemitério público e o que pode ser chamado cemitério de acesso público, o que inclui parte dos cemitérios particulares. Basicamente, assim como em relação à discussão dos espaços públicos e privados da $\operatorname{cidade}^{26}$, os cemitérios de acesso público são aqueles que podem ser frequentados pelo público em geral, independentemente de a propriedade do local ser pública ou privada. Então, neste caso, a noção de público está atrelada à condição de que seja permitido a livre circulação de todos ao local em questão. Solà-Morales chama esse tipo de local de espaço coletivo, buscando evidenciar que eles têm como característica principal serem coletivamente frequentados. Para o autor,

\footnotetext{
"o espaço coletivo é muito mais e muito menos que o espaço público, se caracterizarmos este apenas como propriedade administrativa. A riqueza civil e arquitetônica, urbanística e morfológica de uma cidade, são seus espaços coletivos, todos os lugares onde a vida coletiva se desenvolve, representa e recorda. Talvez estes sejam, cada dia mais, os espaços que não são nem públicos nem privados, se não ambos ao mesmo tempo. Espaços públicos absorvidos por usos particulares, ou espaços privados que adquirem uma utilização coletiva."
}

(SOLÀ-MORALES, 2001, p. 104)

26

Cf. Dimensões públicas do espaço contemporâneo: resistências e transformações de territórios, paisagens e lugares urbanos brasileiros. Eugenio Queiroga, 2012. 
Portanto, o conceito de espaço coletivo busca designar as relações entre os espaços e a vida pública onde e quando ela ocorre. Assim, ao transpor essa discussão para os espaços de cemitério, pode-se introduzir aspectos que contribuem para a compreensão das atribuições, das percepções e dos usos de caráter social em relação a esses locais. Nesse sentido, muitos cemitérios particulares permitem o ingresso a todos, funcionando como espaços de acesso público ${ }^{27}$, enquanto que outros permitem apenas o ingresso apenas daqueles que têm entes queridos enterrados no local ou que são devidamente cadastrados. Evidentemente, a definição sobre a admissão fica a cargo da administração de cada cemitério, que decide de acordo com critérios que julgar pertinente quem pode acessá-lo. Portanto, é necessário avaliar caso a caso se o cemitério particular é ou não um espaço de acesso público.

A conservação e a manutenção desses locais ficam a cargo dos próprios cemitérios particulares, sendo usual a cobrança de tarifas pré-combinadas para tal. Dessa forma, em contraste com grande parte dos cemitérios municipais que cobram diretamente apenas pelo valor do lote usado, os cemitérios particulares costumam apresentar uma maior preocupação com sua aparência e com seu semblante, de modo a associar a ideia de zelo do espaço com o cuidado dos falecidos. Portanto, algumas pessoas acabam por optar pelos cemitérios particulares para sepultar seus familiares por entenderem que assim seus entes queridos serão "mais respeitados e bem tratados" 28 .

As abordagens comerciais em relação aos assuntos de morte não são exatamente uma novidade. Como visto em (2) Cemitérios Eclesiásticos, já na Idade Média eram realizadas cobranças de valores como forma de organizar e restringir os locais de enterros e ajudar na busca pela salvação. Quando o processo de secularização dos cemitérios ocidentais se iniciou, a gestão da morte foi definida de acordo com as peculiaridades de cada sociedade. Assim, houve países em

27 Nota-se que devido a determinação de um horário de funcionamento para os cemitérios, assim como a permissão de acesso, a restrição de acesso se aplica de forma geral. Assim, considera-se espaço de acesso público aquele que durante seu funcionamento qualquer pessoa pode utilizá-lo, a despeito de etnia, classe, gênero, faixa etária ou outros, assim como a partir de seu fechamento, ninguém mais pode entrar. Desse modo, ao menos em tese, não há distinção, e o espaço pode ser considerado de acesso público.

28 Conforme incursão etnográfica realizada no Memorial Parque das Cerejeiras, novembro de 2017. 
que a responsabilidade pelos enterros ficou nas mãos das autoridades municipais ${ }^{29}$, países em que elas foram compartilhadas entre o Estado, as igrejas e as instituições privadas, e países como os Estados Unidos onde coube às entidades particulares conduzir o assunto.

Assim, nestes últimos casos, encontram-se tanto cemitérios que são exemplos de projeto e de gestão cuidadosos, como locais que devido a falta de regulamentação pública se depararam com situações e serviços realizados de forma inadequada, principalmente os direcionados às comunidades mais pobres (WORPOLE, 2003). Ao serem concebidos dentro de uma lógica privada, muitos serviços fúnebres e cemitérios acabaram sendo tratados dentro de uma lógica majoritariamente comercial, o que acabou por definir os aspectos da cultura funerária estadunidense. Muitas das características desse processo são descritas por Jessica Mitford, em seu livro The American Way of Death. Mitford (2000) sugere a existência de um mercado de exploração comercial tendo como pano de fundo o culto da ideia de felicidade. As empresas se apresentam como solução para o "problema", amenizando o desgosto dos sobreviventes e prometendo cuidar da sepultura para o bem-estar dos vivos. Nessas situações, o cemitério passa a ser percebido como um espaço de negociação, onde discutem-se as concessões, multiplicam-se os objetos funerários e, enfim, morrer se transforma em uma transação comercial (RODRIGUES, 2006). Assim, não por acaso que Sloane (1995), ao discutir os cemitérios estadunidenses, defende que a lógica privada e a atividade comercial ao mesmo tempo que impulsionaram o estabelecimento do cemitério como instituição cultural, também foram fatores significativos para o seu declínio como um lugar sagrado e como repositório da história dos lugar e de suas memórias.

Também no Brasil houve tentativas de mercantilização dos assuntos da morte e dos espaços de cemitério. Na Bahia do século XIX, por exemplo, a discussão sobre a concessão do monopólio de enterros a uma empresa que seria responsável por construir o cemitério provocou uma revolta, conhecida como Cemiterada ${ }^{30}$. Propostas desse tipo foram bastante comuns no período, no entanto, elas não foram bem recebidas pois considerou-se, à época, que era indecente que o enterro dos mortos servisse como fonte de lucro privado (REIS, 1991).

29

Países europeus como a França criaram um forte compromisso com a cultura do cemitério, vista como uma expressão dos valores cívicos e coletivos locais que justificava ter seu custeamento feito de forma pública.

30

Cf. João José Reis.

A morte é uma

festa: ritos fúnebres e revolta popular no Brasil do século XIX, 1991 
Assim, é possível perceber que os cemitérios têm sido alvo de uma pretensão comercial desde sua formação, gerando um debate entre uma percepção ética e moral no trato com a morte e os limites admissíveis para se negociar financeiramente um assunto de natureza tão delicada. É fundamental ampliar as discussões sobre as formas de se estabelecer uma boa gestão dos espaços de cemitério considerando seus mais variados aspectos, do econômico e logístico ao cultural e social, de modo a oferecer um tratamento digno após a morte de forma abrangente. Nesse sentido, os cemitérios particulares podem contribuir, tendo em vista levar à sociedade assuntos e valores que vão além de questões financeiras ao considerar toda a complexidade e sutileza que o tema demanda. 


\section{Os Cemitérios no Município de São Paulo}

\section{O Serviço Funerário do Município de São Paulo}

A trajetória da gestão municipal ${ }^{31}$ dos espaços urbanos públicos verdes $^{32}$ em São Paulo pode ser dividida em quatro períodos: 1893 a 1935, 1935 a 1968, 1968 a 1993 e 1993 até os dias atuais (fevereiro de 2019).

O primeiro momento (1893-1935) tem como marco a instauração pelo regime republicano da chamada Inspetoria dos Jardins Públicos, que atuava como um braço da Secretaria da Intendência Municipal, diretamente vinculada ao gabinete do prefeito. Durante as primeiras décadas do século XX, a inspetoria, como órgão responsável pela gestão das áreas de vegetação, passou por diversas mudanças de nome e de jurisdição, até ganhar o nome

31 O Decreto Estadual nº 145 de 1893, transferiu a administração dos jardins públicos da capital à municipalidade. A partir de então, "as Câmaras deliberariam por si sobre Jardins Públicos, e, em geral, sobre os logradouros públicos, e construções em beneficio comum dos habitantes, ou para decoração e ornamentos das povoações" (BARTALINI, 1999, p.26)

32 Entende-se aqui por espaços ou áreas verdes aquelas com predomínio de vegetação. 
de Diretoria dos Jardins e Cemitérios, em 1931. Pouco tempo depois, em 1935 ela foi relocada para o recém-inaugurado Departamento de Obras e Serviços Municipais, ganhando o nome de Subdivisão de Parques, Jardins e Cemitérios. A gestão durante este período se limitava basicamente à conservação das áreas de vegetação através de ações de manutenção como jardinagem, corte de grama, poda, limpeza e vigia (BARTALINI, 1999).

Com a criação da Subdivisão de Parques, Jardins e Cemitérios iniciou-se um segundo período (1935-1968) que trouxe maior complexidade às tarefas e maiores responsabilidades ao órgão. Em 1947, o Departamento de Obras e Serviços foi elevado à categoria de Secretaria de Obras. Com isso, foi criado o Departamento de Serviços Municipais, promovendo a Diretoria de Jardins e Cemitérios à condição de Divisão de Parques, Jardins e Cemitérios. Ela passou a contar com duas Seções: a Seção de Parques, Jardins, Viveiros e Arborização, e a Seção de Cemitérios. Apesar da maior complexidade introduzida, as incumbências da Divisão de Parques Jardins e Cemitérios eram bastante similares ao que já era feito anteriormente, ou seja, administrar e manter áreas verdes, como jardins, praças, parques e cemitérios. Assim, pode-se considerar que a Subdivisão de Parques, Jardins e Cemitérios era um órgão de gerenciamento e manutenção, sem influência na tomada de decisões (BARTALINI, 1999).

É neste período, mais precisamente em 1958, que a Seção de Cemitérios foi desmembrada da Subdivisão de Parques, Jardins e Cemitérios, estabelecendo o Serviço Funerário Municipal (SFMSP) como uma autarquia. A partir de então, jardins, praças, parques de um lado e cemitérios de outro, seguiram caminhos distintos.

Em relação às outras áreas verdes, com o estabelecimento do Departamento de Parques e Jardins inaugura-se um novo período da gestão (1968-1993), vinculando-se a então recém-criada Secretaria de Serviços Municipais. Com isso, jardins, praças e parques começaram a passar por mudanças mais significativas. O novo departamento deveria 
responder não mais apenas pela administração e manutenção das áreas, mas também pelo estudo, planejamento e construção de novos espaços. Em 1976 o Departamento de Parques e Jardins passou a se chamar Departamento de Parques e Áreas Verdes (DEPAVE), tendo sua estrutura mantida até 1993, quando foi criada a Secretaria do Verde e do Meio Ambiente(SVMA), presente até o atual momento (fevereiro de 2019) (BARTALINI, 1999). Já em relação ao Serviço Funerário, ele passou por reformas em 1976 e em 1992, que basicamente representaram um maior detalhamento de suas incumbências e atribuições. Ainda assim, ele se manteve vinculado à Secretaria de Obras, que passou a ser chamada de Secretaria de Serviços e Obras (SMSO) até 2018 quando foi renomeada para Secretaria de Infraestrutura Urbana e Obras (SIURB). Por fim, em 2018, o Serviço Funerário foi transferido para Secretaria Municipal das Prefeituras Regionais (SMPR), onde se encontra até o momento (fevereiro de 2019).

Desse modo, de um ponto de vista administrativo, percebe-se que os cemitérios estiveram por um período de 65 anos (1893-1958) lado a lado com os jardins, praças e parques, depois passaram 60 anos (19582018) junto aos piscinões, pontes, túneis e viadutos na Secretaria de Obras, até passarem a uma secretaria de apoio gerencial e administrativo da Prefeitura, a SMPR.

A determinação da jurisdição do SFMSP é significativa não apenas por uma questão de ordem administrativa, mas por representar um modo de percepção sobre estes lugares. Nota-se como, para a municipalidade, os cemitérios foram cada vez mais sendo tratados como objetos de caráter funcional e logístico, sem maiores objetivos ou atribuições. Ainda, apesar de se configurar como uma autarquia, o cargo de superintendente do serviço funerário dificilmente é valorizado, sendo sua gestão normalmente atribuída a administradores desinteressados que pouco contribuem para o desenvolvimento da questão fúnebre. Assim, tendo como intenção uma mudança efetiva desse panorama, cabe uma reflexão sobre a vinculação e organização do Serviço Funerário junto às entidades de gestão municipal e sobre as formas de valorização deste órgão. 


\section{Cemitérios no Plano Diretor e a ideia de espaço livre}

Os cemitérios apareceram pela primeira no Plano Diretor da cidade de São Paulo no ano de 2002. Além das especificidades relativas ao Serviço Funerário e à gestão da morte como infraestrutura urbana, o Plano Diretor Estratégico (PDE-SP) de 2002 traz nos artigos 131 e 132 da subseção IV das áreas verdes, a inclusão do cemitério no Sistema de Áreas Verdes do Município necessários à manutenção da qualidade ambiental urbana, tendo por objetivo a preservação, proteção, recuperação e ampliação desses espaços (PMSP, 2002, p.103). Assim, ao serem incluídos como áreas de especial interesse, percebe-se um movimento relevante para o entendimento sobre estes espaços, que ganharam amparo legal para serem reconhecidos pela sua importância na qualidade do ambiente urbano.

O Plano Diretor Estratégico de 2014 retoma o tópico dos cemitérios, ampliando a abrangência do Sistema de Área Verdes do Município para o Sistema de Áreas Protegidas, Áreas Verdes e Espaços Livres (SAPAVEL). Na versão do PDE-SP de 2014, os cemitérios ganham uma seção específica, conforme descrição abaixo:

"Seção VI

Dos Cemitérios

Art. 282. Os cemitérios municipais integram o Sistema de Áreas Protegidas, Áreas Verdes e Espaços Livres.

Parágrafo único. O Município deve elaborar o Plano Municipal de Serviço Funerário, definindo uma estratégia para o setor e as ações a serem realizadas nos cemitérios municipais.

Art. 283. O Plano Municipal de Serviço Funerário deve se orientar pelas seguintes diretrizes:

I - requalificar as áreas dos cemitérios na perspectiva de ampliar as áreas livres e as áreas verdes destinadas ao lazer da população;

II - executar a manutenção e conservação, bem como reformas necessárias, das áreas edificadas e tumulares dos cemitérios e crematórios, objetivando a melhoria da qualidade espacial e da infraestrutura existente;

III - estimular a pesquisa e o registro das obras e monumentos tumulares que apresentem valor histórico, artístico, cultural, arquitetônico e científico, com o objetivo de promover a sua conservação e restauro; 
IV - planejar e executar a implantação de cemitérios verticais e crematórios públicos e privados nas diversas regiões do Município, visando ampliar a capacidade do atendimento e liberar áreas municipais para recreação e lazer;

V - planejar e executar a implantação de crematórios públicos para animais domésticos;

VI - estimular a criação de cemitérios e crematórios priva- dos para animais domésticos.

Parágrafo único. As diretrizes previstas nos incisos IV, V e VI, a serem regulamentadas por leis específicas, poderão ser implementadas por meio de parceria com a iniciativa privada."

(PMSP, 2014, p.14)

Assim, a inclusão dos cemitérios no chamado SAPAVEL ampliou a compreensão dos cemitérios para além da questão de áreas de preservação e proteção, trazendo novas perspectivas de abordagem também do ponto de vista cultural e recreativo. Ainda no PDESP 2014, há que se destacar o quadro 7 (PMSP, 2014), Parques Municipais existentes e propostos, onde aparece o Cemitério da Vila Formosa com o código PQ_AF_03, na categoria de parque em planejamento. Divididos em três categorias (parques existentes, parques em implantação e parques em planejamento), o quadro apresenta uma série de parques que necessitam de um estudo de viabilidade para uma discussão sobre sua possível implantação. Ainda que de forma incipiente, a inclusão do Vila Formosa abre caminho para se discutir sobre a utilização de áreas de cemitério como áreas de lazer e cultura junto ao ambiente urbano. O PDE-SP de 2014 apenas coloca como diretriz a intenção de se estabelecer um parque no local. Para tal, é preciso ter em mente que atuar em um espaço de cemitério não significa retirar-lhe sua destinação fundamental de tratar dos assuntos fúnebres, mas reconhecer a complexidade e o potencial dos cemitérios junto ao meio urbano. Nesse sentido, ao ampliar o debate sobre as formas de se criar novas novas relações, é possível realizar algumas reflexões a respeito do entendimento dos cemitérios como espaços livres.

Como descreve Miranda Magnoli (2006, p.179), “o espaço livre é todo espaço não ocupado por um volume edificado (espaço-solo, espaço-água, espaço-luz ao redor das edificações a que as pessoas têm acesso)". Usando esta definição, poderíamos deduzir que o cemitério, em quase sua totalidade, pode ser considerado um espaço livre, como exceção das parcelas que são ocupadas por edificações, como as áreas de administração, velório, capelas, etc. No entanto, ao se pensar nessa lógica em relação aos espaços de sepultura, é preciso fazer uma distinção entre os cemitérios tradicionais e os cemitérios-jardim. 
No caso dos cemitérios tradicionais, eles apresentam uma série de tipologias arquitetônicas, que podem ser agrupadas em dois conjuntos: construções que não oferecem abrigo, como (1) sepultura, (2) oratório, (3) estela, (4) jazigo monumento e (5) túmulo verticalizado, e construções que oferecem abrigo, como (6) jazigo capela e (7) mausoléu. Assim, de acordo com o conceito de Magnoli, as construções que não oferecem abrigo funcionam como monumentos e esculturas, podendo ser consideradas integrantes do espaço livre cemiterial, enquanto que as construções que oferecem abrigo são, evidentemente, edificações que atuam como intervalos construídos no espaço. Ao visitar alguns dos cemitérios em São Paulo, mesmo em um levantamento superficial, percebe-se que a maior parte dos espaços costuma ser do primeiro grupo, conformando o local então como um espaço preeminentemente livre.

Já nos cemitérios-jardim, devido a ausência de volumes ou objetos construídos sobre a terra, a associação do local como espaço livre é mais direta. Nestes cemitérios, os caixões costumam ser colocados diretamente sob a terra, sendo usadas placas, símbolos ou algum outro meio de identificação para indicar a inumação no local (8). Ainda, muitos cemitérios-jardim particulares constroem jazigos subterrâneos (9) que podem comportar um número maior de corpos, permitindo que familiares ocupem um mesmo local.

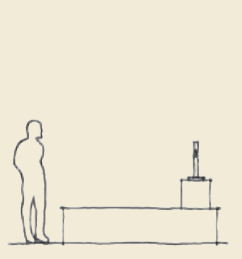

1
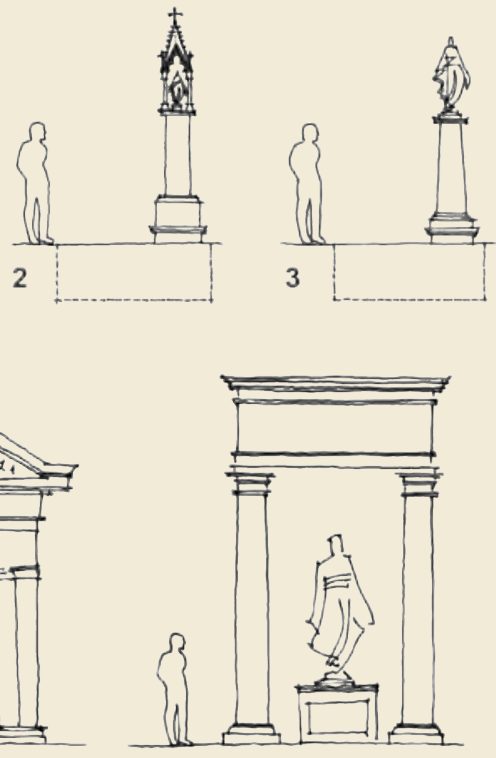

7

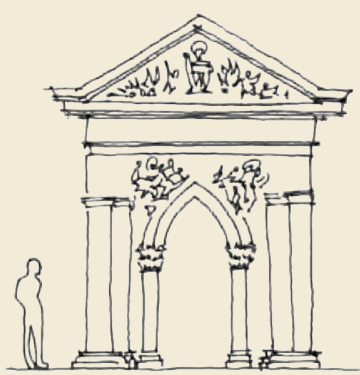

6

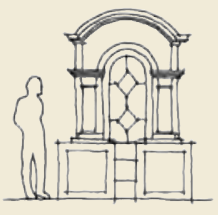

4
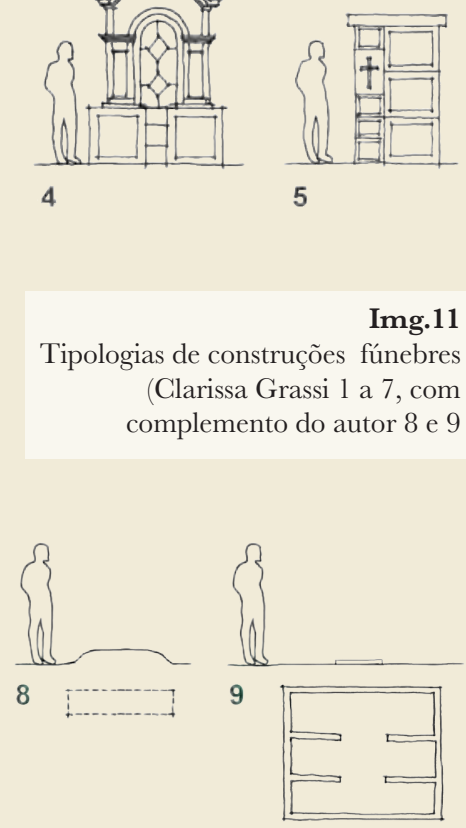

Img.11 nebres Clarissa Grassi 1 a 7, com complemento do autor 8 e 9 
Desse modo, constata-se que a maior parte dos espaços de cemitério, mesmo as parcelas que têm a presença de corpos enterrados, podem ser consideradas integrantes do espaço livre. No entanto, ao se debruçar sobre o sentido de livre para além da questão dos volumes construídos, cabe uma reflexão sobre o sentido que o termo pode conotar quando transposto ao cemitério.

Por mais que os espaços de cemitério sejam majoritariamente livres de edificações e, portanto, livres para pisar, chover, iluminar, etc., eles não costumam ser livres na percepção e consciência das pessoas. É possível pensar algumas situações que levam a esse entendimento. Por exemplo, percebe-se que a simples indicação de que alguém está enterrado em determinado local é suficiente para que o comportamento se altere. Ao tomar conhecimento dessa condição, é comum que as pessoas optem por dar a volta, por não pisar "sobre o falecido" para não lhe "faltar com respeito"33. Assim, a consciência de que há um corpo ali marca um ponto de virada na percepção. Nesse sentido, percebe-se que ao visitar cemitérios-jardim que têm sua paisagem marcada pela presença de extensos gramados, as crianças, menos atentas ao conteúdo nos subsolos, tendem a atravessar os gramados sem receios e ressentimentos. Nestes casos, enquanto alguns pais ou familiares deixam elas andarem e até brincarem, "pois são crianças”, outros não gostam da atitude e dizem que não se pode pisar ali ${ }^{34}$.

33

Conforme incursão etnográfica realizada no Memorial Parque das Cerejeiras, novembro de 2017.

34

Conforme incursão etnográfica realizada no Memorial Parque das Cerejeiras, novembro de 2017 .

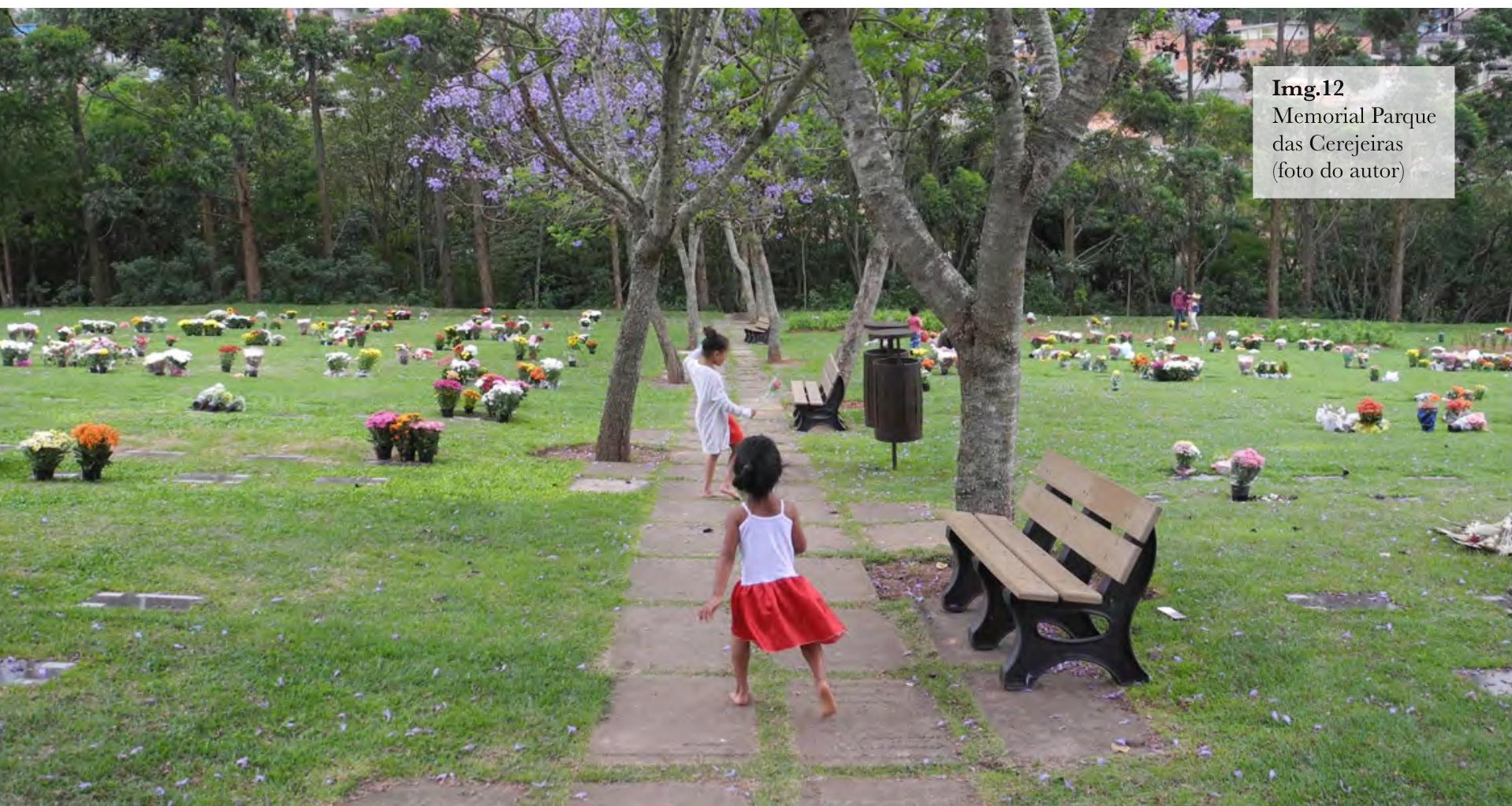


Dessa forma, para além da noção de ocupação do espaço, pode-se pensar em um sentido de livre ligado à percepção de um sentimento distinto no cemitério. Nesses locais, o sentido de livre não está mais em oposição ao ocupado (como algo construído), mas ao preenchido (como algo percebido), distinguindo-se do espaço livre de uma praça ou um de parque. Assim, ao mesmo tempo que é importante a assimilação dos cemitérios junto aos espaços livres da cidade, cabe refletir sobre os limites de atividades e as normas de comportamento no cemitério. Afinal, ele é um espaço livre em termos dos gestos e das ações?

\section{O Programa Memória \& Vida}

O Programa Memória \& Vida $(\mathrm{M} \& \mathrm{~V})$ foi uma iniciativa realizada pelo Serviço Funerário de São Paulo, em parceria com a Fundação São Paulo (Fundasp), mantenedora da Pontifícia Universidade Católica de São Paulo (PUC-SP). O programa foi implementado em julho de 2015, através de um convênio, tendo funcionado até dezembro de 2016, quando foi finalizado junto ao mandato municipal daquele momento (2013-2016). Seu objetivo, de acordo com o próprio programa, é:

"analisar e subsidiar a gestão e as formas de relacionamento entre o serviço
funerário e a sociedade em prol da qualidade, da humanização e do
aprimoramento desse serviço público. O programa busca a construção de
uma forma inovadora de relações entre o cemitério e a cidade através de um
trabalho interdisciplinar que visa repensar os tabus que tangenciam a morte
e ressignificar os espaços cemiteriais como parques de memória.” (SFMSP e FUNDASP, 2016, p.7)

Como conta a superintendente do SFMSP durante a época ${ }^{35}$,

35

Conversa realizada com o autor em 21 de novembro de 2017.

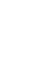

Lúcia Salles França Pinto, ao iniciar a gestão, o primeiro aspecto que chamou atenção foi a ausência de servidores ligados à questão do luto e da memória na equipe profissional. Até aquele momento, os encargos da autarquia estavam estritamente relacionados à questão da deposição do corpo após o óbito. Lúcia Salles conta que achava tão fundamental mudar 
esse panorama, que brincava que iria mudar o nome do Serviço Funerário para Serviço Municipal de Luto e Memória. Este novo posicionamento, representado por uma visão mais ampla sobre o SFMSP, foi estrutural para a instauração do Programa Memória \& Vida, sendo ele parte de um empenho para a reconfiguração da forma de gestão da morte junto à cidade. Desse modo, foi adotada uma abordagem multidisciplinar, estabelecida através da aproximação com a pesquisa e a extensão universitária representada pela PUC-SP. Para tal, foram traçadas duas vertentes de atuação: a produção de conhecimentos relacionados ao luto; e a formação de um grupo de pesquisa sobre manutenção e preservação patrimonial das obras de arte existentes nos cemitérios tradicionais da cidade.

Em relação ao primeiro objeto, tendo como pressuposto que o assunto é visto pela sociedade sob uma ótica negativa e tétrica, foram realizadas diversas atividades e eventos voltados a uma revisão da relação com a morte, subsidiados pela realização de seminários, encontros, oficinas e publicações informativas sobre o assunto. Procurou-se discutir o tema tanto com a população enlutada, como com os funcionários e servidores do SFMSP, de modo a oferecer as bases para esse novo entendimento. Nesse sentido, como lembra Lúcia Salles, um bom exemplo é o filme $A$ Partida ${ }^{36}$, que conta a história de um agente funerário japonês (nōkanshi) sob uma ótica de valorização da importância e do respeito desta função.

Já no segundo caso, o foco principal do programa foi o Cemitério Consolação, onde foi desenvolvido um trabalho científico e cultural de valorização do patrimônio tumular e de preservação e divulgação da memória da cidade. Neste caso, conforme descrito em publicação sobre a produção do programa (SFMSP e FUNDASP, 2016), foram feitos levantamentos museológico, de acervo e de inventário, elaborados laudos de conservação e realizada curadoria artística e histórica para identificar as personalidades e obras presentes no cemitério. A partir dos dados levantados, foi criado um aplicativo informativo para visitas autoguiadas e um site na internet para consulta de dados de sepultamentos ${ }^{37}$.

36

A partida (Okuribito). Direção: Yojiro Takira, Produção: Toshiaki Nakazawa, Japão: Shochiku, 2008.

37

Na data de publicação desta dissertação (fev. 2019), o site já não estava mais no ar. Em maio de 2018, a TV-PUC publicou, vídeo resumo sobre a produção do Memória \& Vida no Cemitério Consolação <www.youtube.com/ watch?v=VPG_JhZ3Tu4\&t $=15 \mathrm{~s}>$ Acesso em: 10 jan. 2019. 
Além da boa presença de público notada durante os eventos, foi realizada uma pesquisa com os frequentadores do local (SFMSP

e FUNDASP, 2016), que se mostraram favoráveis a realização de atividades diversas no local.

39

Entre eles, pode-se citar o

Movimento em Defesa do

Cemitério da Consolação

(MDCG), criado justamente em resposta ao Memória \& Vida, que acredita que parte das atividades sugeridas pelo M\&V eram inadequadas e representavam a profanação do lugar, que deve ser tratado como um campo santo.
Em relação ao uso do Cemitério Consolação, foi incentivada a realização de diversas atividades no local, como o chamado "cinetério" (projeção de filmes), apresentações musicais ou teatrais e as chamadas "pedaladas", ampliando a utilização desse espaço para além da questão dos enterramentos. Nestes casos, é válido destacar que apesar da boa receptividade a estas atividades $^{38}$, houve quem se posicionasse de forma contrária à presença deste tipo de evento ${ }^{39}$. Ainda assim, apesar da discordância sobre estas atividades, em relação à organização e sistematização de visitas turísticas houve uma consonância, valorizando a importância histórica do lugar, o acervo artístico e a presença dos corpos de personalidades marcantes para a história da cidade e do país. A boa receptividade das visitas fez com que elas fossem ampliadas e incluídas de forma regular na programação do Consolação, inserindo o espaço de cemitério no roteiro turístico oficial da cidade.

Desse modo, o Memória \& Vida pode ser visto como uma experiência precursora de maior utilização dos espaços de cemitério na cidade, apresentando um repertório de iniciativas que podem ser usadas na elaboração de futuros projetos relacionados a esses lugares. Como lembra a arquiteta Karla Rothstein (2016, p.110), “a sociedade é marcada pelo contexto e as dinâmicas sociais são ditadas pelos espaços que habitamos coletivamente. Ao retraçar a ubiquidade da morte em nossas cidades, nos recordamos da finitude da vida e do frágil compromisso que os vivos compartilham, para fortalecer o futuro". Nesse sentido, Lúcia Salles conta que a ideia por trás do Memória \& Vida estava ligada tanto com a forma de gestão da questão fúnebre, como com a forma de aproveitamento dessas áreas numa perspectiva da dinâmica urbana:

\footnotetext{
"Se a gente não ocupar o lugar de forma cidadã, fica um vácuo. Aí entra destruição, roubo e furto. Só se a gente permitir se apropriar daquele espaço é que ele vai virar um espaço público. E olha, tem mais, não tinha dinheiro, mas eu era a favor mesmo de derrubar os muros e colocar grade, porque tem que ter olhar. É melhor para segurança, é melhor para preservação, e deixa as pessoas verem como é um lugar bonito."
}

(SALLES, 2017, conforme conversa com o autor) 

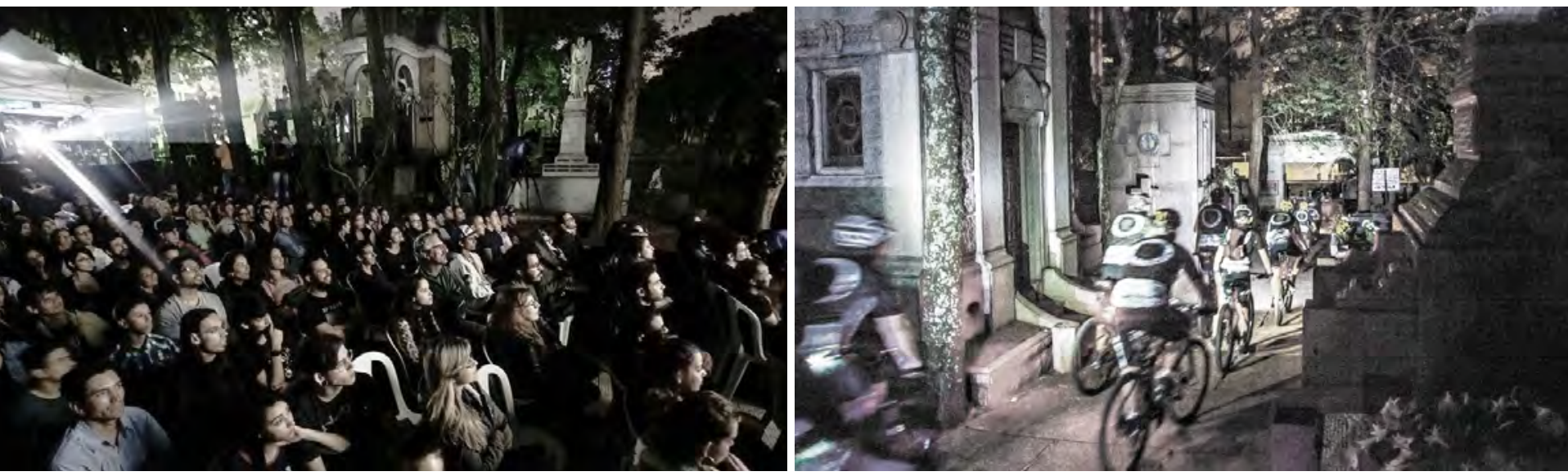

Img.13 "Cinetério" no Cemitério Consolação (folhapress) Img.14 Pedal Caveira no Cemitério Consolação (metrojornal)

Portanto, percebe-se que a criação de programas, políticas públicas e projetos urbanos pode contribuir para apresentar novos panoramas e soluções para os espaços de cemitério junto ao contexto urbano e social de uma metrópole como São Paulo. Nesse sentido, será preciso pensar formas pelas quais políticas públicas bem-sucedidas possam ter continuidade através da mudança de administração, de modo a evitar que a qualidade ou efetividade delas esteja sujeita a questões de interesse meramente políticos ou ideológicos. Apesar de todas as críticas e discordâncias que possam existir em relação ao Programa Memória \& Vida, é fundamental discutir seu legado de modo a considerar seu possível papel na reconfiguração da gestão funerária do município, incluindo as questões de luto, memória e de uso dos espaços de cemitério. No entanto, o conteúdo e as experiências trazidas pelo Memória \& Vida, no lugar de serem ampliados e discutidos, foram deixadas de lado. Percebe-se que mesmo informações e documentos já produzidos não estão mais acessíveis. Até a presente publicação desta dissertação (fevereiro de 2019), a gestão da Prefeitura de 2017-2020 apresenta a seguinte nota a respeito das ações e programas previstos para o SFMSP: "As metas que a Autarquia deverá se pautar durante a gestão 2017-20 estão em construção. Em breve, publicaremos as informações atualizadas" ${ }^{40}$. Na prática, a Prefeitura abriu mão de seu papel na definição do tema, optando pela terceirização da questão através da abertura de um edital de Procedimento de Manifestação de Interesse (PMI) para a concessão dos cemitérios municipais.

40 Site da Prefeitura de São Paulo, Disponível em < $<w w$. prefeitura.sp.gov.br/ cidade/secretarias/ obras/servico_ funerario/acesso_a_ informacao> Acesso em: 10 jan 2019. 


\section{$\underline{\text { A concessão dos cemitérios municipais }}$}

Como bens públicos de competência dos municípios, embora os cemitérios públicos costumem ser administrados diretamente pelas prefeituras, existem mecanismos que permitem que eles possam ser geridos por terceiros através de concessão ${ }^{41}$. A Prefeitura de São Paulo publicou em junho de 2017 um edital de Procedimento de Manifestação de Interesse (PMI) para a concessão dos cemitérios e do crematório do município. O edital teve como objetivo que as empresas interessadas em assumir a gestão desses espaços elaborassem uma apresentação com "estudos de modelagem operacional, econômico-financeira, jurídica e de engenharia e arquitetura para a revitalização, modernização, operação, manutenção e gestão.” (PMSP-SMDP, 2017, p.1). De acordo como a Secretaria Municipal de Desestatização e Parcerias (SMDP), responsável pela concepção do documento,

\footnotetext{
"A missão disso tudo é para que a população de São Paulo receba um serviço muito melhor e mais digno, garantindo a gratuidade para quem não pode pagar e a segurança nos cemitérios, iluminação, boas salas de velório, desenvolvimento, para que esses serviços tenham um retorno melhor sem gasto público."
}

(Site da SMDP-SP, 2017, acesso em 10 de janeiro de 2019)

De acordo com a Prefeitura, São Paulo registra aproximadamente 85 mil óbitos por ano, dos quais cerca de 45 mil dos sepultamentos e 10 mil das cremações são realizados pelo serviço público municipal, gerando despesas à cidade. A Prefeitura defende que, ao transferir a gestão dos espaços, poderia empregar esses recursos em outras áreas que demandam mais investimentos. De acordo com a SMDP, um dos principais objetivos do PMI é receber análises sobre a política tarifária dos serviços cemiteriais. Para isso, ao mesmo tempo em que devem ser mantidas as gratuidades vigentes, é possível introduzir tarifas de manutenção e segurança, assim como é realizado nos cemitérios particulares. Ainda, o edital prevê que as empresas podem contemplar propostas de modelos para arrecadação de receitas através de lanchonetes, restaurantes, floriculturas, venda de velas e outros serviços relacionados aos cemitérios. 
Alguns meses após sua publicação, em setembro de 2017, o processo de concessão foi suspenso pelo Tribunal de Contas do Município (TCM-SP) ${ }^{42}$ que apontou incongruências e chamou atenção para a falta de informação e de clareza do edital. O TCM-SP pediu esclarecimentos relativos ao funcionamento da gratuidade dos sepultamentos, à falta de critérios para a análise dos estudos, à inexistência de prazo para a concessão ${ }^{43} \mathrm{e}$ à divisão dos cemitérios em blocos de forma não justificada ${ }^{44}$. Ainda, o TCM-SP questionou o não estabelecimento de um valor mínimo para a concessão e contestou a ausência de dados essenciais para a apresentação dos estudos, como o número de sepulturas existentes nos cemitérios. Para o TCM-SP, sem essas informações, a Prefeitura não tem base de comparação e não é possível avaliar a lisura do processo e saber se a Municipalidade terá ganho ou prejuízo com as concessões.

Ainda nesse sentido, cabe uma reflexão sobre o próprio discurso econômico empreendido pelo SMDP e pelo edital, que deixa à cargo da iniciativa privada definições de maior importância. Ao se discutir a questão dos custos do Serviço Funerário e de seu eventual déficit, é preciso ter em mente que ele funciona como um monopólio. Dessa forma, a própria Prefeitura poderia adequar os preços praticados pelo Serviço Funerário de modo a equilibrar as contas e, possivelmente, até gerar receitas que poderiam ser usadas para aprimorar os espaços e os serviços dos cemitérios municipais. No entanto, parece que a Prefeitura, através da atuação da Secretaria de Desestatização e Parcerias, tem a concessão ou a privatização como fim e não como meio para seus objetivos, independente das perdas a que o Município estaria suscetível.

42 “Tribunal de Contas suspende concessão de cemitérios em SP”. Márcio Pinho, G1, São Paulo, 28/09/2017. Disponível em <globo.com/sao-paulo/noticia/tribunal-de-contas-suspende-concessao-de-cemiterios-em-sp. ghtml> Acesso em: 11 jan. 2019.

43 O edital coloca apenas que a proposta deve prever o tempo mínimo de 20 anos, mas não especifica tempo máximo e outras informações sobre o assunto (SMSP-SMDP, 2017, p.24).

44 O edital separou os cemitérios em 4 blocos, da seguinte maneira (SMSP-SMDP, 2017, p.2 e p.3):

Bloco 1: Cemitérios de Campo Grande, Lajeado, Parelheiros, V. Mariana, Tremembé e V. Formosa I e II

Bloco 2: Cemitérios do Araçá, Dom Bosco, Itaquera, Santo Amaro e São Paulo

Bloco 3: Cemitérios da Freguesia do Ó, Lapa, Quarta Parada, Santana e Saudade

Bloco 4: Cemitérios Consolação, Penha, S. Luiz, S. Pedro, V. Nova Cachoeirinha e V. Alpina (Crematório) 
Ainda, a falta de informações e de clareza não ficou restrita apenas à avaliação do TGM-SP ou a questões econômicas. Ao analisar as atas de reuniões realizadas ${ }^{45}$, percebe-se a insuficiência de conhecimento sobre a situação e a condição das áreas a serem concessionadas pelos membros da SMDP. Grande parte dos questionamentos levantados pelos interessados na concessão sobre esses pontos não são respondidos, ficando a cargo dos concorrentes elaborar os planos simplesmente com base no que julgarem mais adequado. Nesse sentido, mesmo em uma avaliação elementar do material disponibilizado pela Prefeitura é possível encontrar dados contraditórios. Por exemplo, ao avaliar as plantas dos cemitérios apresentadas ${ }^{46}$, percebe-se uma incongruência de informações com as áreas oficiais divulgadas para cada local. Em alguns casos, a diferença entre a área numérica indicada em planilha ${ }^{47}$ e a área gráfica calculada é de mais de 20\%. Chama atenção também a quantidade de erros nas bases gráficas, que não apenas estão incompletas, como, em alguns casos, têm o perímetro dos cemitérios apresentado de forma imprecisa ${ }^{48}$.

Percebe-se, então, que a preparação para o

45 Reuniões realizadas em 04/08/2017, $11 / 08 / 2017,15 / 08 / 2017,18 / 08 / 2017$, 25/08/2017, 01/09/2017, 05/09/2017, 06/09/2017, 15/09/2017, 17/05/2018, 24/05/2018, 25/05/2018 e 15/06/2018. Atas disponíveis em www.prefeitura. sp.gov.br/cidade/secretarias/ desestatizacao/projetos/cemiterios/index. php?p=236439> Acesso em: 10 jan. 2019.

46 Plantas disponíveis em <www. prefeitura.sp.gov.br/cidade/secretarias/ desestatizacao/projetos/cemiterios/index. php?p=236439> Acesso em: 10 jan. 2019.

47 Planilha disponível em < drive.google. com/file/d/0B-j2xIrFvrW5NUFRS2tza0NhQm8/view> Acesso em: 10 jan. 2019.

48 Na elaboração desta pesquisa, para ter a definição de alguns cemitérios a mais atualizada possível, foi feito levantamento junto à administração de alguns cemitérios, além da coleta de informações em campo e do cruzamento com imagens aéreas. processo de concessão foi realizada sem o devido cuidado, demonstrando descaso inclusive na apresentação das informações. $\mathrm{O}$ edital foca quase que unicamente em aspectos da gestão financeira, tratando o cemitério meramente como uma estrutura de armazenamento de corpos falecidos. Ele ignora questões fundamentais trabalhadas pelo Memória \& Vida, como a relação dos cemitérios com a cidade e a importância dos assuntos de memória e de elaboração do luto. Essas questões, independentemente da forma de gestão, são de suma importância para se refletir sobre o tema da morte e dos cemitérios na atualidade. É fundamental a atuação da Prefeitura e do planejamento urbano em conduzir os múltiplos aspectos presentes nesses espaços de modo a atender da melhor forma os interesses dos munícipes e do município. Através do edital apresentado, a gestão municipal abriu mão do papel de definir os rumos do assunto. No entanto, como coloca Solà-Morales 
“...a cidade é precisamente o lugar onde o particular pode ser - e amiúde é - social: tanto ou mais que o público, a boa cidade é aquela em que os edifícios particulares - sobretudo os bons edifícios - valores sociais que os extrapolam, e nisso está seu modo de ser urbanos. (...). Não se leia este argumento como um canto neoliberal à autonomia privada. O que dele se deduz é o contrário, que a função intervencionista do setor público atende, não só ao modo privado - às suas áreas de propriedades - como procura dar qualidade coletiva ao que não o é. Quem sabe seja mais atraente e fácil para um administrador municipal desenhar um parque ou uma calçada do que discutir a possibilidade de melhorar os projetos privados sem executá-los. Acredito que lutar pela qualidade desses espaços coletivos - ao mesmo tempo privados e público, públicos e privados - é a principal tarefa do arquiteto na cidade. Porque a boa cidade é a que consegue dar valor público ao privado."

(SOLÀ-MORALES, 2001, p.106)

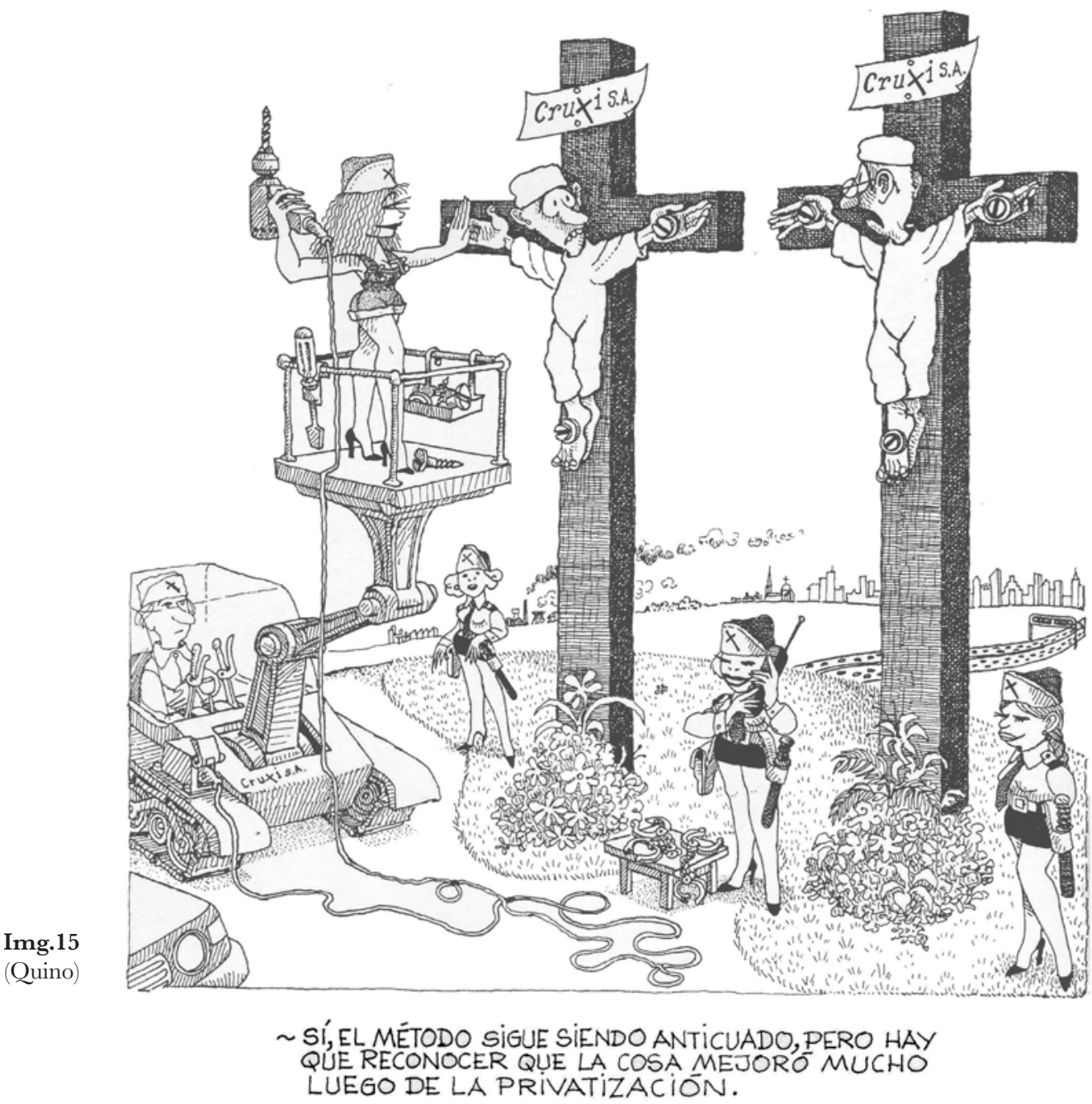




\section{Gemitérios no município de São Paulo}

Os cemitérios se tornaram figuras bastante presentes na cidade de São Paulo a partir da explosão demográfica e da expansão urbana ocorrida desde primeira metade do século XX. O município de São Paulo possui (em fevereiro de 2019) 40 cemitérios (Img.16), sendo $21^{49}$ deles de gestão pública municipal e 19 de gestão privada. Em termos de ocupação, as áreas dos cemitérios somam um total aproximado de $5,5 \mathrm{~km}^{2}$ (Img.17), sendo possível encontrar desde cemitérios bem pequenos como o Cemitério de Colônia, com 1.250m², até o Cemitério Vila Formosa, um dos maiores do mundo com mais de $763.000 \mathrm{~m}^{2}$.

Em relação à distribuição desses espaços pela cidade, observa-se que houve um espraiamento geográfico dos cemitérios ao longo do tempo, principalmente em relação aos cemitérios particulares, ocupando áreas mais afastadas onde se encontram locais de maiores dimensões. A exceção deste fenômeno fica por conta dos pequenos cemitérios criados a partir da concessão de parcelas de terrenos de cemitérios públicos, que na prática representam um desmembramento de cemitérios públicos pré-existentes.

Dentre as características físico-espaciais dos cemitérios paulis-

49

O site da Prefeitura de

São Paulo apresenta o registro de 22 cemitérios pois, devido à sua dimensão, o Cemitério da Vila Formosa teve sua administração divida em duas partes - Vila Formosa I e Vila Formosa II, no entanto, esta pesquisa entende que ambos os núcleos conformam um espaço que pode ser considerado único. tanos, encontra-se uma distribuição equilibrada entre as tipologias de cemitérios tradicionais e a de cemitérios-jardim, sendo ainda possível encontrar casos que possuem uma composição mista (Img.18).

A configuração de cemitério do tipo tradicional foi hegemônica nos primeiros cemitérios, sendo utilizada frequentemente até meados do século XX. A predileção por essa tipologia tem como referência a herança cultural católica, principalmente portuguesa, e seu uso de imagens religiosas. Já os cemitérios-jardim, começaram a ganhar mais espaço em São Paulo por volta da década de 1950, tendo se expandindo cada vez mais desde então (Img.19). As influências para a constituição desses espaços vieram de países com maior presença do cristianismo protestante, como a Inglaterra e os Estados Unidos. Usualmente ocupando espaços de maiores dimensões, grande parte dos cemitérios-jardim se estabeleceu em locais mais afastados do centro da cidade, onde encontraram maior terreno para instalação. Desde então, esse tipo de cemitério tem se expandido de forma significativa, 
consolidando-se como opção preferencial na maior parte dos cemitérios implantados. O modelo de cemitério-jardim tem sido adotado tanto em cemitérios particulares como em cemitérios públicos, que buscam ser mais atrativos através da associação com a ideia de espaço verde. Nesse sentido, contribuiu para a difusão do cemitério-jardim um relatório produzido por um grupo de trabalho instituído pela Prefeitura para estudar a questão dos cemitérios na cidade em 1966. Entre as principais diretrizes sugeridas pelo relatório, estava a recomendação de que os próximos cemitérios construídos pelo município seguissem esse padrão. Ainda, de acordo com publicação do Serviço Funerário Municipal feita em 1977, o plano da instituição era expandir as áreas gramadas dos cemitérios existentes, com o objetivo de torná-las o mais próximo dos cemitérios-jardim. A intenção desta operação seria tornar tais lugares "mais verdes, e, portanto, mais agradáveis e humanos", se enquadrando em uma ideia de retirar seu aspecto lúgubre (SANTOS A., 2014).

Em relação às características dos sepultamentos, os cemitérios de São Paulo seguem boa parte do que foi descrito em relação aos cemitérios públicos. Eles apresentam os três tipos descritos anteriormente: concessão perpétua, concessão temporária e permissão de uso, que é utilizada no sistema de quadra geral. $\mathrm{O}$ sistema de concessão perpétua está presente na maior parte dos cemitérios municipais, havendo uma divisão entre três grupos de cemitérios, para o qual são adotados diferentes valores, de acordo com a localização do cemitério. Nestes casos, após um período prolongado, caso seja diagnosticado o estado de abandono do túmulo, a Prefeitura pode reaver o espaço e ceder o local para outro munícipe ${ }^{50}$. Já a concessão temporária é encontrada nos cemitérios São Pedro (Zona Leste), Dom Bosco (Zona Norte) e Vila Nova Cachoeirinha (Zona Norte), podendo variar entre 5 ou 25 anos. Por fim, o sistema de quadra geral é adotado apenas nos cemitérios da Vila Formosa (Zona Leste) e São Luís (Zonal Sul ${ }^{51}$, que invariavelmente se configuram como locais para as classes de mais baixa renda. Ainda, para aqueles que não tenham condições de arcar com as despesas de funeral é 50 Conforme Artigo 39 do Ato Prefeito n ${ }^{\circ} 326$, de 1932. Disponível em $<$ legislacao.prefeitura. sp.gov.br/leis/ato-gabinetedo-prefeito-326-de-21-demarco-de-1932> Acesso em: 12 jan. 2019.

51 Informações retiradas da Tabela de valores de concessões e terrenos em cemitérios, do Serviço Funerário do Município de São Paulo, de 10 de maio de 2015.

52 Conforme Lei 11.083 de 1991. Disponível em $<$ legislacao.prefeitura. sp.gov.br/leis/lei-1 1083-de6-de-setembro-de-1991> Acesso em: 12 jan. 2019. possível realizar o enterro sem custos nestes locais ${ }^{52}$. 


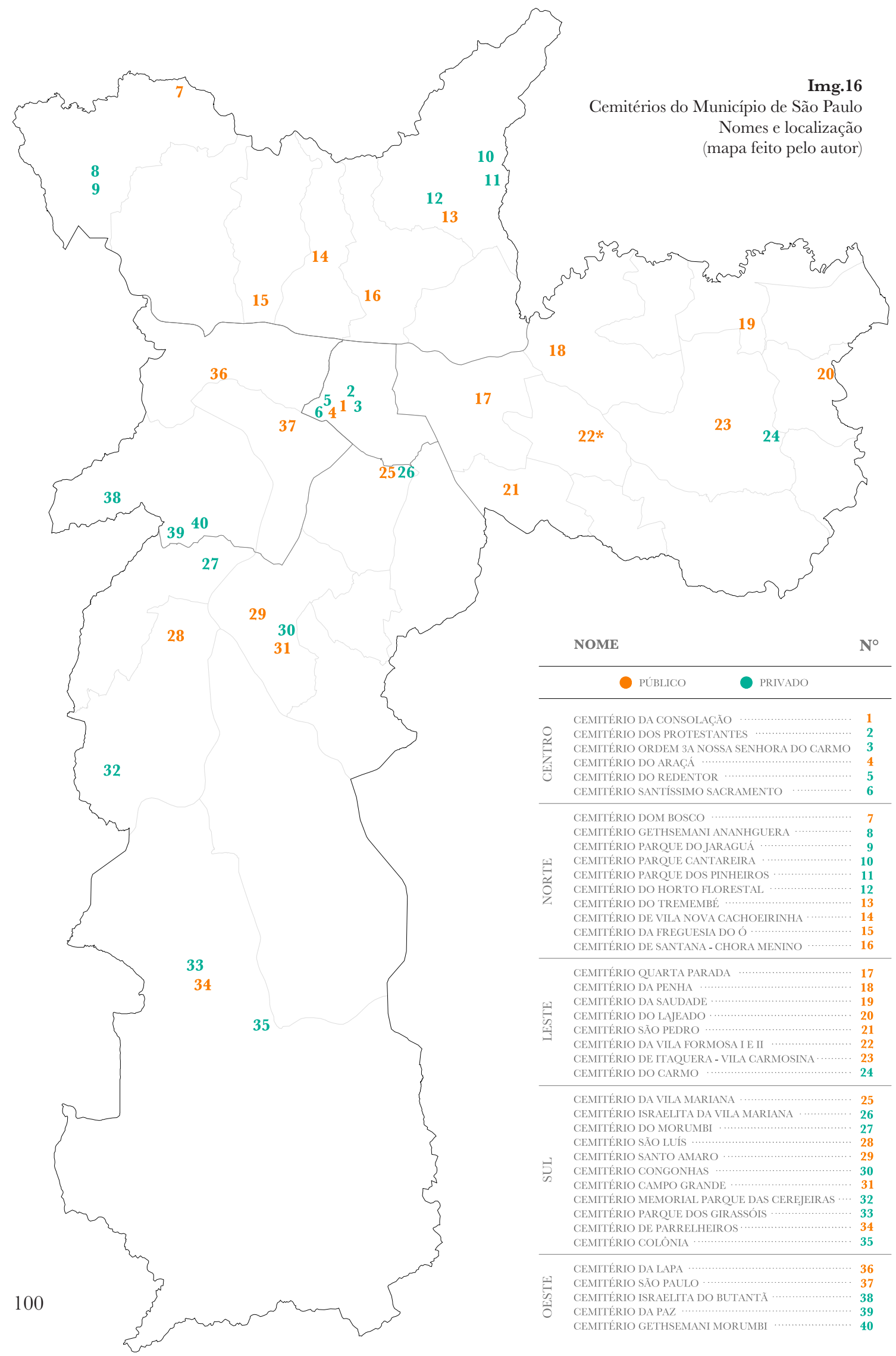




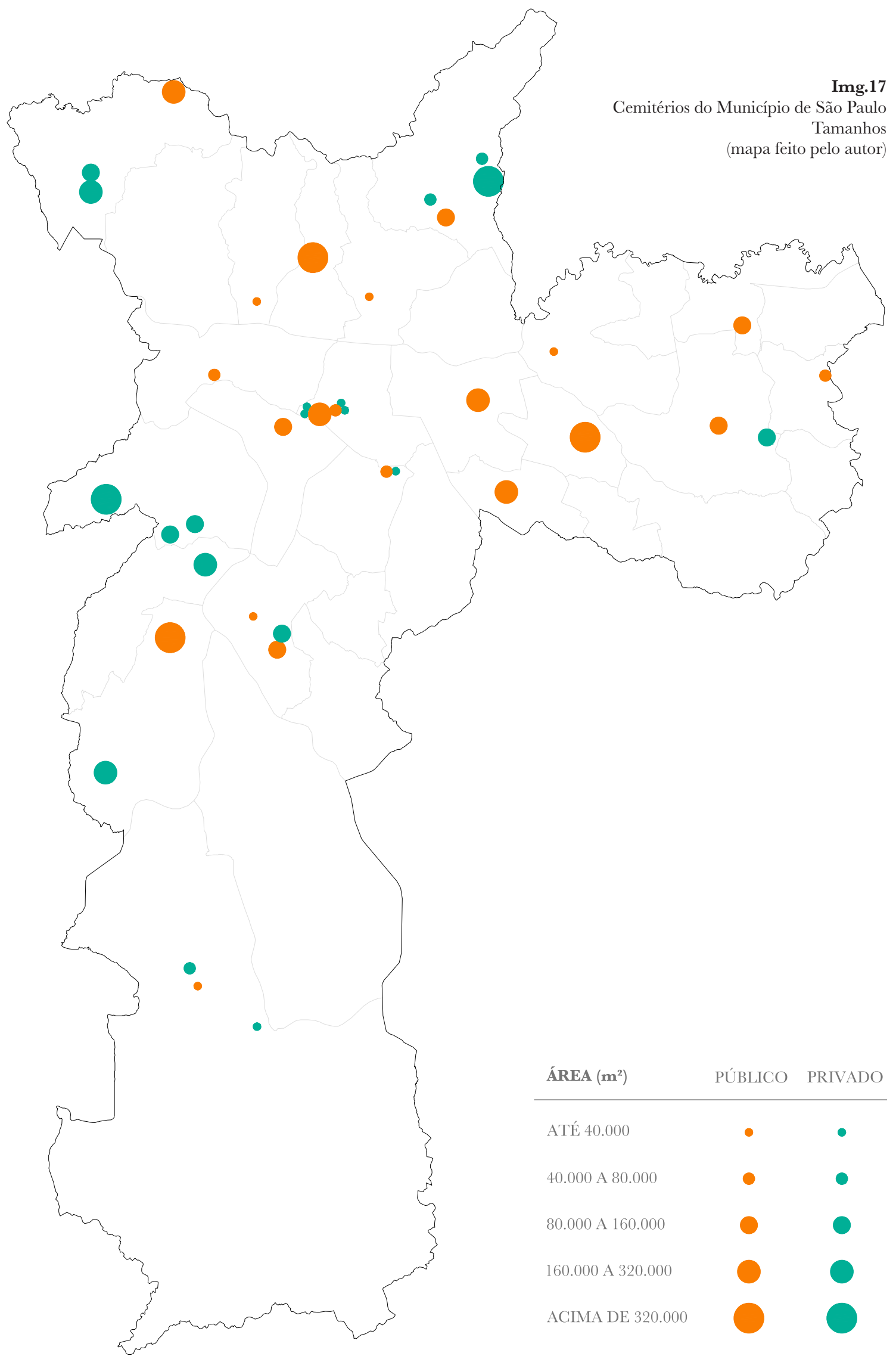




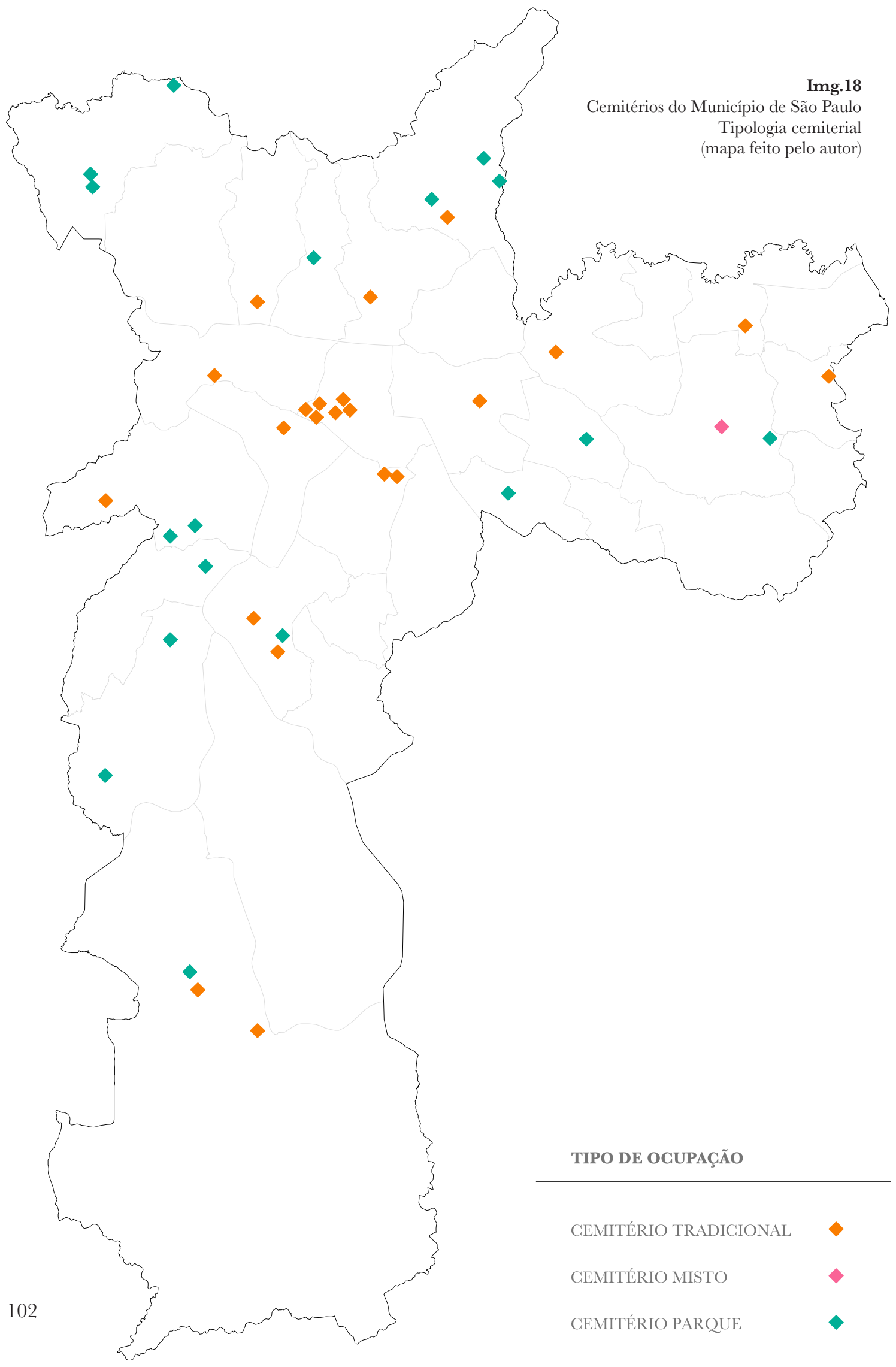




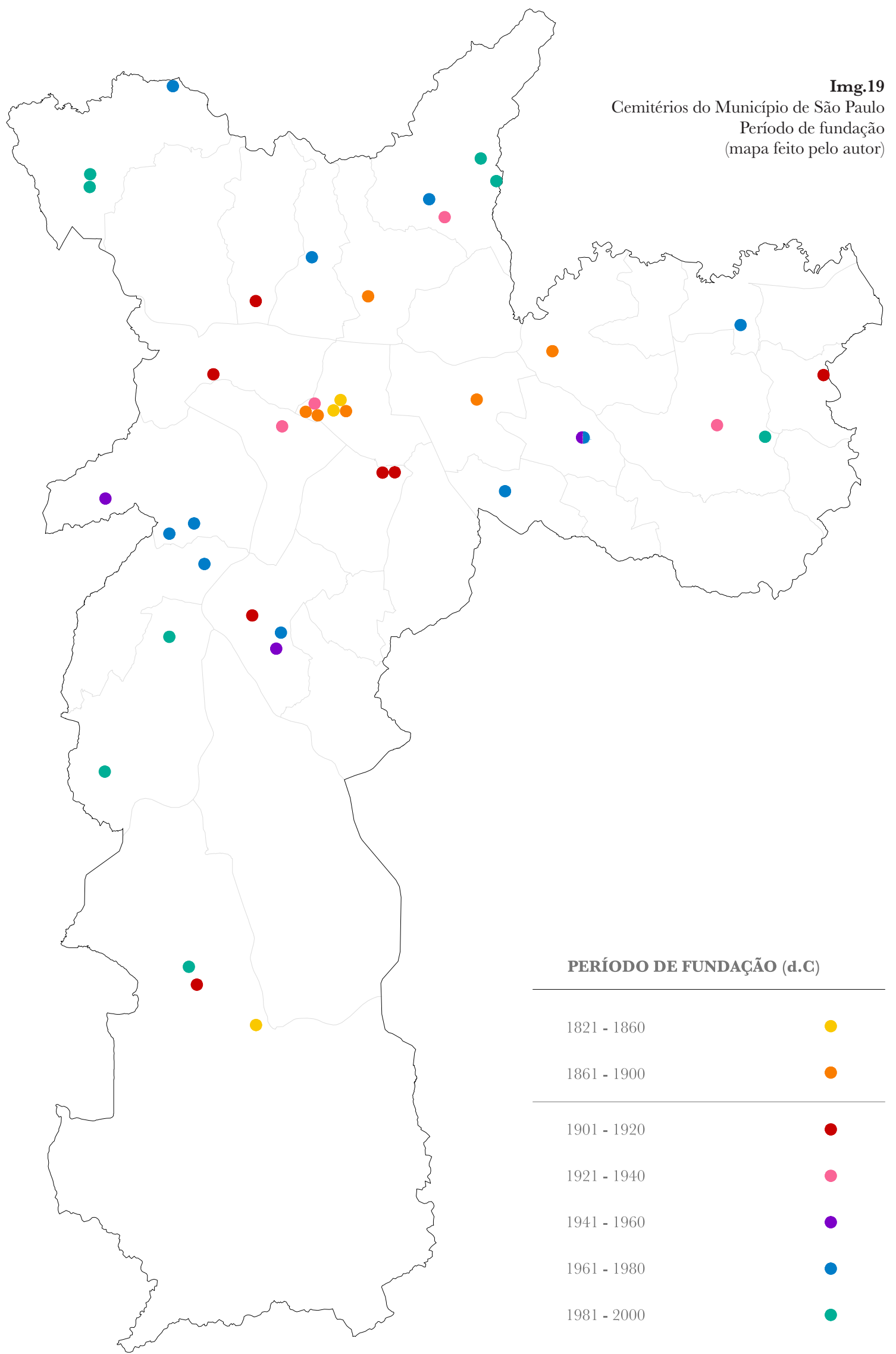


Quanto aos cemitérios particulares, eles são 53 permitidos em São Paulo desde $1951^{53}$, sendo a política de valores definidas por cada entidade em questão. Assim, dentre os diversos de cemitérios particulares da cidade, é possível encontrar diferentes tipos de serviços e de valores que buscam, à sua maneira, estabelecer-se de modo atraente Conforme Lei 4.100 de 1951 $<$ www.leismunicipais.com. $\mathrm{br} / \mathrm{a} / \mathrm{sp} / \mathrm{s} / \mathrm{sao}-\mathrm{paulo} / \mathrm{lei}-$ ordinaria/1951/410/4100/leiordinaria-n-4100-1951-dispoesobre-cemiterios-particulares> Acesso em: 20 dez. 2017.

frente à concorrência. Desse modo, tendo como objetivo atrair mais concessionários, são adotadas as mais variadas ações e estratégias. Nesse sentido, em relação ao espaço em si, em comparação com os cemitérios municipais, muitos cemitérios particulares apresentam uma maior preocupação com os aspectos e a aparência do local, chegando inclusive a chamar arquitetos e paisagistas para elaborarem projetos que buscam uma melhor qualidade ambiental, espacial e paisagística do lugar.

Ainda, em alguns casos específicos, é possível encontrar cemitério particulares que buscam incentivar uma abordagem mais humanista, refletida não apenas na percepção de cuidado para com o corpo do falecido, mas também na configuração do espaço de cemitério como um espaço para os familiares e frequentadores. Na região de São Paulo, destacam-se dois locais que seguiram essa linha de atuação, o Cemitério Memorial Parque das Cerejeiras, situado na zona sul da cidade, e o Cemitério e Crematório Primaveras, que fica à nordeste de São Paulo, no município de Guarulhos. Procurando se destacar em relação a outros cemitérios particulares da região, esses locais apresentam diversas atividades extra funerais que buscam ampliar o papel dos cemitérios junto à sociedade e gerar maior atratividade ao local. Para tal, eles oferecem programações culturais como a realização de apresentações musicais, exposições de arte e cerimônias de celebração em ocasiões especiais como o dia de finados. Ainda, o Memorial Parque das Cerejeiras, devido a boa presença de vegetação existente em seu terreno, foi pensado de modo a ampliar o acesso público a áreas verdes para os moradores das regiões no seu entorno, o Jardim Ângela e o Jardim Capela. Assim, além das áreas de sepultura, o local foi planejado de modo a oferecer outros tipos de espaço como área de parquinho para crianças, bosque com animais, mirante para o Parque Estadual Guarapiranga e uma praça memorial nomeada de Praça da Eternidade. Como conta a paisagista Mônica Lauretti, uma das responsáveis pelo projeto do Memorial Parque da Cerejeiras, a intenção é 
"Que a pessoa esteja cercada de paz, para suportar o momento, que esteja cercada de coisas boas para olhar e assim, na medida do possível, ajude a minimizar a parte difícil de lidar com morte. Então oferecemos, para quem quer passear, um bosque, para ter a possibilidade de sair andando se for o caso. Tem também opção para quem quer ficar sentado, mais longe, mais perto, em grupo ou sozinho."

(LAURETTI, 2017, conforme conversa com o autor)

Desse modo, junto à iniciativa do Programa Memória \& Vida na gestão do Serviço Funerário de 2013-2016, também na administração privada de cemitérios é possível encontrar novas formas de abordagem da morte e de seus espaços que buscam ampliar o entendimento sobre o assunto tendo em mente o contexto social, espacial e urbano em questão.
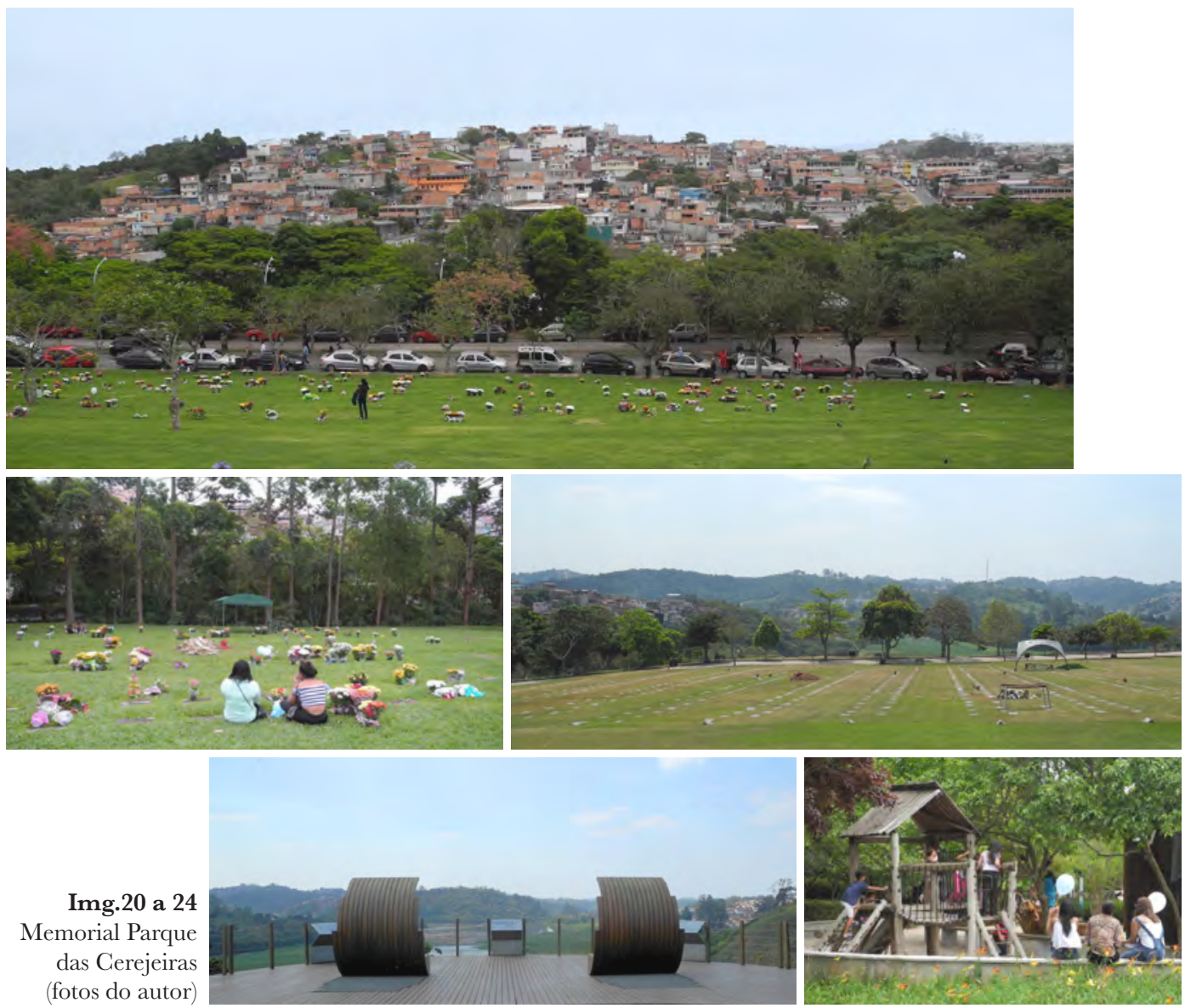



\section{Parte II}

Sentidos e Percepções 



\section{Morte, Ausência e Semiótica}

A morte vai muito além do momento em que um indivíduo deixa a vida. Ela não é limitada a uma transição instantânea de um estado para outro, mas é um processo complexo que demanda tempos alongados e que possui diversas facetas: morte biológica, morte social, morte íntima. Portanto, o estudo da morte é permeado por questões relacionadas aos simbolismos e às representações presentes nesse processo. A partir de uma análise acerca desse tema, esta pesquisa busca distinguir a estrutura dos componentes funerários comuns na cultura ocidental, de modo a criar bases para se discutir os espaços de cemitério na atualidade.

Logo de início, é possível destacar um tema constante em relação à morte: a ausência. Em Antropologia da imagem, Hans Belting se dedica a investigar o tema da morte, dos mortos e de sua representação na arte, nos indicando um caminho para compreender essa questão. $\mathrm{O}$ autor argumenta que "o morto será sempre um ausente e a morte uma ausência insuportável que os vivos tentam suprir de 
Belting desenvolve em seu livro as concepções de imagem, meio e corpo. Para o autor, a imagem não

é algo físico, concreto, mas funciona como uma formulação abstrata, uma referência construída para ajudar na compreensão de determinado tema.

Ainda sob a perspectiva de Belting, o meio configura algo concreto, uma espécie de suporte sobre o qual projeta-se uma imagem concebida.

diversas maneiras" (2014, p.182). Para Belting, uma das formas de preencher a lacuna deixada pelo morto é através da imagem $^{54}$ na condição do que se pode chamar de presença de uma ausência. $\mathrm{O}$ autor argumenta que, na tentativa de superar a ausência, a maior parte das culturas associa os mortos a objetos e lugares específicos onde, mediante a imagem, ganham um corpo simbólico, imortal, ao qual ele se refere como o $\mathrm{meio}^{55}$. Com isso, os vivos podem voltar a se relacionar e a socializar com os mortos, enquanto o corpo mortal tem seu curso definido pela sua decomposição ou metamorfose. O lugar em que isto ocorre na cultura contemporânea ocidental é, majoritariamente, o túmulo, localizado nos cemitérios. Portanto, a partir da lógica de Belting, é possível construir um raciocínio onde o túmulo se apresenta não apenas como um local de descanso do corpo, mas um lugar de ação, onde o tempo da morte é processado e transformado. Assim, a decomposição no túmulo constitui uma representação e reiteração da imagem da morte onde, de acordo com cada singularidade e tempo específico, a catástrofe da morte vai sendo substituída pelo controle e pela aceitação. Essa passagem é elaborada a partir de uma condição em que a ordem é restaurada por uma ação cerimonial. Neste momento, o morto ganha um lugar no espaço social, fazendo com que o evento ritual substitua o acontecimento biológico (BELTING, 2014). Dessa forma, a desordenação na vida social causada pela morte é atenuada, sendo o rito funerário fundamental no enfrentamento da ausência sentida, um modo de reordenação. Nessa mesma linha de pensamento, como destaca Rodrigues (2006), os funerais são ao mesmo tempo, em todas as sociedades, uma crise, um drama e uma solução. Eles são, em geral, uma transição do desespero e da angústia ao consolo e à esperança.

A partir dessa consideração, é possível traçar um paralelo entre o conceito de imagem de Belting e a discussão colocada por Edgar Morin, que afirma que as diversas combinações de crenças, ideologias e formas de elaborar a morte estão estritamente relacionadas com a 
ideia do duplo. Para Morin (1997), o duplo seria como uma espécie de alter ego do vivo, sua sobrevivência por meio de espectro, ou ainda, uma extensão que emana do indivíduo após sua morte. Se é possível observar uma grande variedade de práticas cerimoniais fúnebres, ao pensar na ótica do duplo pode-se notar que elas têm uma mesma finalidade em comum: oferecer ao morto uma residência temporária durante a etapa de dissolução do corpo e suprimir a imagem de sua decomposição. Nesse raciocínio, se em muitas situações o enterro e a cremação podem ser vistos de forma antagônica, dentro da perspectiva do duplo essa oposição perde sentido. Para tal, é preciso partir do reconhecimento de que a cremação não visa a extinção do cadáver, como pode se pressupor, mas oferece as cinzas como transmutação do corpo. A cremação apenas acelera o que Morin chama de "libertação do duplo" (1996, p.131), eliminando a etapa de decomposição em que o corpo e o duplo ainda estão conectados. Assim, constata-se que tanto o enterro como a cremação buscam determinar um ponto de apoio ${ }^{56}$ para o duplo, quer seja no corpo como um todo, quer seja em parte dele. Mesmo nos casos onde esse apoio pode se dar em um substituto simbólico, eles se apresentam como suportes do culto prestado ao morto, são intermediários. Assim, podemos melhor compreender a afirmação de Morin de que as práticas referentes ao cadáver em geral visam "garantir a serenidade do duplo e localizar seu culto." (1997, p. 133).

O simbolismo funerário ganha então importância de modo a dar uma dimensão efetiva ao ausente, proporcionando condições para que as questões material e espacial encontrem lugar. Isso ocorre através do estabelecimento de formas e signos que têm o intuito de substituir e simbolizar o indivíduo falecido, como duplos, amenizando a dor da ausência e contribuindo para a elaboração da morte. O túmulo então aparece novamente como o grande representante dessa estrutura, atuando de forma a articular dois níveis: o invisível, situado debaixo da terra; e o visível, representado pelo objeto tumular construído,
56

O ponto de apoio pode ser entendido como qualquer meio, conforme discutido por Belting (2014), seja ele físico ou abstrato, onde o enlutado pode encontrar amparo frente à ausência trazida pela morte. 
assumindo a condição de "um monumento colocado entre os limites de dois mundos" (SAINT-PIERRE, 1868, apud CATROGA, 2010, p.167). O túmulo atua então como elemento de comunicação entre os mundos dos vivos e dos mortos. Também nesse sentido, Vernant (1990) destaca o papel da pedra como marco dessa relação, evocando o conceito do kolossós. Segundo ele, o termo kol contém a ideia de alguma coisa ereta, erguida. Assim, o túmulo, ao oferecer uma pedra que emerge da terra, assume, ao mesmo tempo, o papel de marcar a separação entre os vivos e o morto e de estabelecer o contato entre ambos. Para Vernant, não é a imagem do morto que está encarnada na pedra, mas sua vida no além. O kolossós sobe à luz do dia e manifesta aos olhos dos vivos uma presença, presença esta insólita e ambivalente, que como visto, é também o sinal de uma ausência.

Desse modo, se por um lado a invisibilidade atenua o trabalho da corrupção do corpo, por outro, o objeto assume o papel de criar uma imagem atenuada do cadáver e da morte através da semiótica, transmitindo às próximas gerações signos que funcionam como sua representação. Catroga (2010, p.167) se refere a esse processo como a "re-presentificação" do finado, termo sugestivo para uma compreensão que transita entre os conceitos de representação e de ausência-presença. Assim, tendo em mente os conceitos desenvolvidos até aqui, pode-se destacar a posição emblemática dos cemitérios em abrigar múltiplas imagens e duplos e, assim, "localizar o sem-lugar", conforme expressão de Peter Johnson (2012, p.4, tradução nossa). Essa ideia é parte inerente da concepção dos espaços fúnebres, constituindo-se como fundamental para a compreensão e reflexão sobre o sentido destes espaços. 


\section{Vínculos: Memória, Religiosidade, Luto}

\section{Memória, identidade, reconhecimento}

As discussões sobre o local de sepultura têm, além da importância semiológica discutida anteriormente, um papel fundamental para os estudos da memória. As diversas imagens e duplos presentes no cemitério assumem um papel importante como signos e marcos de reverberação tanto de memórias, como da memória. Pode-se notar a relação entre essas ideias, por exemplo, através da palavra grega para sinal, sema, que é também a palavra usada para designar o túmulo (HARRISON, 2003). Por sua vez, seguindo uma discussão sobre os termos usados para o local de enterro, túmulo e tumba têm raiz na noção de algo que se sobressaí, uma protuberância, por exemplo, que pode ser decorrente do enterro de um corpo em determinado local, como destaca Pedro Azara no prefácio do livro de Mônica Gili sobre construções tumulares (GILI, 1999). Portanto, o túmulo apresenta um sentido duplo, dado pela 
manifestação de algo que se revela à percepção visível, como pela marca do signo de um lugar de desaparecimento, que cria uma referência. Outro termo que ajuda na compreensão sobre a simbologia do túmulo é a concepção de monumento. Em latim, a palavra monumentum remete à men, que exprime uma das funções essenciais do espírito, a memória (menini). Já o verbo monere, também do latim, significa fazer recordar (LE GOFF, 1990). Assim, atendendo à sua raiz etimológica, o monumento é tudo aquilo que pode evocar o passado e perpetuar a recordação, o que leva à percepção de que os signos funerários, como os túmulos, têm uma acepção monumental em sua relação com a memória.

Dessa forma, usando como referência a noção de Le Goff de que toda a linguagem da memória é simbólica ${ }^{57}$, Catroga (2010) coloca que o cemitério apresenta um caráter monumental manifestado através da expressão simbólica de seus marcos fúnebres, que o levam a assumir a função de lugar de produção e reprodução da memória. Dessa forma, o autor explica o porquê da primazia desse significado recair sobre os cemitérios modernos: devido à sua caracterização formal e ao repertório de suas construções tumulares.

Seguindo esse raciocínio, é possível perceber que os

57

Le Goff (1990) coloca que toda memória opera por símbolos que exprimem um estado de espírito, uma situação, uma relação, uma identidade, ou mesmo uma essência inerente ao grupo.

58

Cf. Entre memória e história: a problemática dos lugares, Pierre Nora, 1993. cemitérios se encontram intimamente atrelados ao conceito de lugares de memória, seguindo o termo cunhado por Pierre $\mathrm{Nora}^{58}$. Se, como visto anteriormente, a construção da relação com os mortos e a preservação de suas personalidades é realizada através de sua substituição por símbolos equivalentes, sejam eles lápides, epitáfios, fotografias, esculturas ou outros, o cemitério se configura como o local paradigmático de representação desses símbolos. Ele assume a função de acolher as diversas identidades das comunidades em que está inserido, abrigando histórias, peculiaridades e características que o configuram como importante ponto de preservação das memórias. Assim, o espaço do cemitério ganha significado social através do estabelecimento de uma relação com a memória ancorada na experiência espacial, temporal e corporal existente no lugar. 
Doris Francis (2003) trata de um tema similar ao sustentar que o cemitério pode ser entendido como uma representação coletiva, uma espécie de réplica simbólica que expressa as crenças e valores básicos de uma sociedade. Para tal, a autora define o cemitério como o espaço socialmente demarcado para a realização de funerais e celebrações fúnebres que ordenam as relações entre vivos e mortos. Assim, em termos objetivos, enquanto mentalmente o funeral transfere o indivíduo de um tempo linear para um tempo eterno, espacialmente os signos materiais do cemitério atuam de modo a localizar os mortos e estruturar o espaço. O cemitério se apresenta então como uma espécie de “artefato material” (WARNER, 1959, apud FRANCIS, 2003, p.223, tradução nossa), onde as relações com a morte são ordenadas e delimitadas, afirmando a existência social dos falecidos através da perpetuação de suas memórias. Desse modo, ao se determinar o local de um sepultamento, estabelece-se um ponto físico onde um grupo social pode se reunir e compartilhar seu luto, sua dor. É possível então constatar como os cemitérios configuram-se como importantes referências para o reconhecimento de identidades, assumindo papel relevante em casos não apenas de memória familiar-pessoal, mas também em aspectos de reconhecimento de memórias e identidades sociais ${ }^{59}$. Assim,

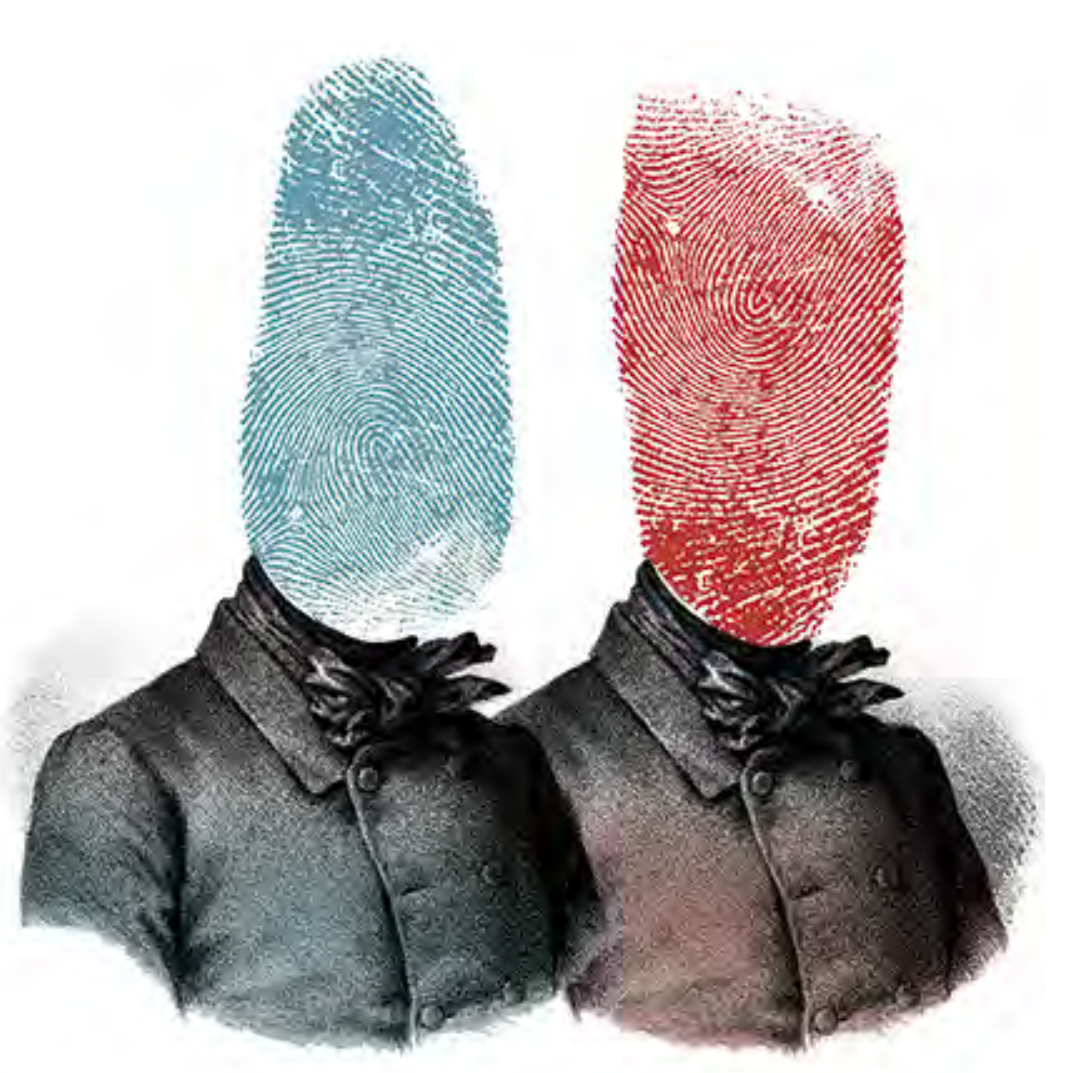

59

Nesse sentido, Andreas

Huyssen (2014) destaca

a importância de os

estudos contemporâneos

de memória buscarem

relacionar a memória

com história e com os

direitos humanos, de

modo a impedir que a

memória, sobretudo a

memória traumática, se

torne objeto de um campo vazio, restrito apenas a si mesmo.

Img. 25

(elsrgarcia.com) 
ao localizar esse marco em um espaço público ou em um espaço acessível como os cemitérios, cria-se condição para o encontro e a confraternização (FRANCIS, 2003). Esse raciocínio é importante ao se considerar uma discussão que permita refletir sobre os meios, condições e características desses encontros, tendo em mente debater a atual conjuntura dos espaços de cemitérios.

Ainda, cabe ressaltar que os objetos no cemitério não são psicologicamente dissociáveis tanto da estrutura em que estão integrados, como das crenças e sentimentos com que são entendidos. Como destaca Urbain (1978), o lugar e o signo no cemitério estão de tal modo imbricados um no outro que nenhum dos dois é fenomenologicamente separável, tornando natural a relação entre o significante, o significado e o referente (o morto ausente). Assim, ao estabelecer uma relação onde se convoca o invisível através do visível, tem-se como decorrência o estabelecimento de um espaço intrinsecamente dialético, que proporciona sensações variadas e até ambíguas. Acolhimento e angústia, tranquilidade e inquietação, atração e medo. O cemitério se apresenta então como o cenário de memórias-simbólicas e de memórias-construídas, abrindo espaço ainda para as memórias-vividas, decorrentes da vivência nesses locais. Assim, contrapondose a uma conotação predominantemente mórbida sobre os símbolos funerários, Urbain (1978) pontua que eles funcionam como um convite a uma periódica ritualização revivificadora. Para o autor, a experiência nesse local é para ser vivida e para ajudar a viver, oferecendo-se a uma leitura cuja compreensão mobiliza, antes de mais nada, toda a subjetividade do sobrevivente.

Por fim, a importância memorial do cemitério pode ser entendida não apenas do ponto de vista das afetividades e identidades, mas também como meio de afirmação dos limites que a morte representa para o ser humano. Os romanos adotaram a expressão memento mori para reforçar esse condição, usando-a como um lembrete para o fato de que, em certo momento, todos morrem. Essa recordação não tinha como objetivo uma visão fatalista da morte, mas era usada como forma de valorização da vida. Assim, em uma conjuntura onde evita-se pensar sobre a morte (o que paradoxalmente indica uma desvalorização da vida), o cemitério cumpre a função primordial de lembrar do estado inexorável da finitude, ele próprio torna-se um memento mori. 


\section{Religiosidade, paisagem, atmosfera}

Para o antropólogo Bronislaw Malinowski (apud WALTER, 1993) o fenômeno da morte foi a principal inspiração para muitas crenças religiosas que emergiram em sociedades e culturas humanas ao longo da história. Assim, a religião forneceu as principais explicações sobre a conformação do mundo e sobre como a morte humana pode encontrar lugar nessa topografia (WORPOLE, 2003). Tomando o cristianismo como exemplo, para os primeiros cristãos, o céu e o inferno eram lugares reais, parte da geografia e geologia do próprio mundo real, como muitos mapas medievais revelam. Assim, a paisagem, com seus lugares sagrados, era um terreno altamente moralizado no cristianismo (WALTER, 1993).

A influência da religiosidade ${ }^{60}$ e dos mortos na forma e experiência da paisagem é objeto de discussão do geógrafo Yi-Fu Tuan. Para tal, ele desenvolveu o conceito de geopiedade (geopiety), termo primeiramente cunhado por John Kirtland Wright. Para Tuan (apud CARPENTER, 2008), a geopiedade denomina a relação entre a morte, a paisagem e um sistemas de crenças. $\mathrm{O}$ termo tem como base a ideia de que a morte possui um forte sentido ritualístico que é baseado na ideia de reciprocidade. Assim, ao mesmo tempo que os antepassados são venerados através do culto, eles precisam da ação ritual para desempenharem seu papel. A geopiedade carrega então uma ideia de ciclo ritual sustentado pela ideia de veneração. Tendo em mente que na maioria das culturas os locais de sepultamento são considerados lugares consagrados, a ideia de geopiedade pode reforçar a importância de reverência pelo lugar junto à noção de reciprocidade que é parte de muitas culturas religiosas.

60 Nota-se que o termo religiosidade deve ser entendido como a disposição para refletir sobre aspectos que vão além da compreensão humana. Desse modo, independentemente da religião (ou falta de), a religiosidade se refere a um ato de convicção para com um sentido (ou falta de) sobre a morte. 
Atualmente, a busca por significados da paisagem perpassa as camadas de religiosidade, ampliando-se para outros domínios. Assim, a apreciação do tema tem sido estudada dentro de uma dinâmica que considera a combinação de questões como a imaginação humana, respostas visuais aprendidas e percepção social. Desse modo, a noção de paisagem passa a apresentar interpretações e significações que podem ser associadas tanto à natureza como à cultura, uma categoria mental e sensível da percepção humana (SERRÃO, 2011). Nesse sentido podemos discutir a noção de stimmung, termo alemão de caráter polissêmico e de difícil tradução. A filósofa Adriana Serrão chama a atenção para a interpretação do termo por Simmel (2009) que o entende pela convergência de três aspectos: a conformação única das partes que dotam cada paisagem de um caráter individual; a conjunção dos traços psíquicos do sujeito numa disposição singular; e a fusão de ambas numa atmosfera única. Assim, buscando uma aproximação conceitual da ideia de stimmung, é possível relacioná-lo com o termo atmosfera, dando a ele um enfoque à experiência da sintonia entre a objetividade de suas peculiaridades e a subjetividade de sua percepção. Assim, a stimmung da paisagem permite a conciliação entre natureza e cultura, possibilitada pela atmosfera comum a ambas, sem que se antropomorfize a natureza, ou naturalize o homem, assistindo-se a uma doação recíproca no lugar da paisagem (DUGOS, 2013).

A ideia de atmosfera da paisagem ganha novos significados no cemitério, ligando-se a questões suscitadas pela morte como a religiosidade, a finitude e a própria existência. Assim, sua estética e linguagem desempenham um papel importante para a percepção, permitindo construir pontes entre a vida e a morte. Assim, pode-se dizer que, em certo sentido, os lugares dos mortos são paisagens essenciais, lugares onde são mantidos em equilíbrio morte e vida, passado e futuro, mundo material e mundo espiritual. Como coloca Augustin Berque, "a paisagem diz respeito ao visível, mas também ao invisível. Ao material, mas também ao espiritual. É esta ambivalência o que é essencial, e o que faz a realidade da paisagem (BERQUE, 2009, p.85). 


\section{Luto, interlocução, ambiência}

A morte é, para a consciência coletiva, uma ruptura, o afastamento entre o indivíduo e a convivência humana. Como coloca o sociólogo Robert Hertz (1970), esta separação pressupõe a transferência do recém falecido de uma sociedade concreta (dos vivos), para uma sociedade abstrata (dos mortos). Como fenômeno social, a morte e os ritos a ela associados consistem fundamentalmente em estabelecer os meios dessa passagem para a morte. Ao longo da história, pode-se observar que nenhuma sociedade se comportou de forma alheia ao corpo falecido, mas cada grupo social estabeleceu um sistema de crenças e práticas específicas para lidar com essa questão. As diversas perspectivas teológicas sobre a morte constituem uma das mais ricas abordagens humanas, colocando as religiões como os principais meios para se lidar com a morte nas sociedades ao longo da história ${ }^{61}$.

Para além das questões de religião, algumas áreas do conhecimento têm abordado a problemática da morte (no sentido de perda), buscando contribuir e oferecer recursos para se lidar com uma das questões mais complexas da experiência humana, se não a maior delas. Apesar da grande dificuldade que esse processo representa, recentemente parece haver um consenso nas áreas que tratam da relação com a morte, como a psicologia e a psiquiatria, de que a melhor forma de lidar com essa questão passa por trabalhar e vivenciar o luto, e não por escapar ou evitar o tema ${ }^{62}$. Nesse sentido, é comum o uso das ideias de luto saudável, para os processos daqueles que conseguem encontrar os caminhos de se retomar a vida, e luto complicado, para aqueles que acabam estagnados e apresentam maiores dificuldades de seguir, não resolvendo a relação de perda. Entre os esforços para se sistematizar o entendimento desse processo, destaca-se o trabalho de Elizabeth Kübler-Ross (1992), que usa como referência para a descrição do processo de luto cinco etapas: negação, raiva, negociação, depressão e aceitação.

61

As próprias religiões foram constituídas, principalmente, a partir do mistério da morte.

62

Tem-se como base para essa afirmação os estudos de Maria Júlia Kovacs desenvolvidos no Laboratório de Estudos sobre a Morte do Instituto de Psicologia da Universidade de São Paulo (LEM-IPUSP). 
Ressalta-se, porém, que o tempo de luto não é um tempo contínuo que conta dias, meses ou anos, mas é baseado em um tempo cíclico, que surge em datas ou momentos próprios, apresentando-se como reminiscências imprevisíveis (CERTEAU, 1998). Essa percepção é compartilhada pelos psicólogos Margaret Stroebe e Henk Schut (1999) que propõem uma perspectiva do processo de luto, concebido como um processo não linear e oscilatório, ao qual nomearam de Modelo de Processo Dual de Enfrentamento do Luto, durante o qual o enlutado oscila entre o enfrentamento orientado para a perda e o enfrentamento orientado para a restauração ${ }^{63}$.

Percebe-se então que o luto é um processo dinâmico,

O enfrentamento orientado para a perda refere-se a lidar com a perda, concentrandose nela e trabalhando alguns de seus aspectos, entrando em contato com a dor que esta experiência imprime e sua expressão, tal como reposicionamento da relação com a pessoa que faleceu. $\mathrm{O}$ enfrentamento orientado para restauração refere-se a lidar com as tarefas, reorganizar a vida e desenvolver novas identidades, assumindo os papéis e tarefas que a nova condição impõe.

Ao longo das incursões etnográficas aos cemitérios do Araçá e da Vila Formosa, realizadas em novembro de 2017, foi possível encontrar referências a essa noção por diversas vezes, principalmente nesse sentido de reportar aos pais e avós os encaminhamentos da vida pessoal, como uma espécie de diário familiar. dotado de ritmos próprios e, portanto, não homogêneo. A ruptura da convivência com o falecido acaba por determinar a necessidade de se encontrar novas formas de relação. Uma das possibilidades de se estabelecer essa nova relação é dada pela noção de que os mortos podem ouvir, uma ideia provavelmente tão antiga quanto a própria cultura funerária. Para muitos, o local da sepultura de um ente querido se torna um ponto importante para manter ou estabelecer os vínculos, conversar sobre questões não resolvidas antes da morte ou ainda como forma de contar aos seus entes queridos sobre as "coisas da vida" ${ }^{64}$. Assim, percebese que as paisagens, os edifícios e os artefatos fúnebres não são apenas elementos da topografia do cemitério, mas podem assumir o papel de ponto de interlocução entre os vivos e os mortos.

Portanto, ao se dedicar a uma reflexão sobre a paisagem e a arquitetura fúnebres, é possível incitar uma discussão sobre as formas e os meios com que elas podem contribuir na vivência da perda e da desesperança decorrentes das ocasiões de luto. Nesse sentido, mostra-se necessário refletir sobre como levar em conta diferentes características dos lutos e de suas temporalidades, de modo a encontrar formas de oferecer apoio nos espaços e arranjos funerários. A aproximação com a morte pode demandar, em alguns aspectos, uma mudança de ritmo, uma desaceleração, ou até mesmo uma suspensão. 


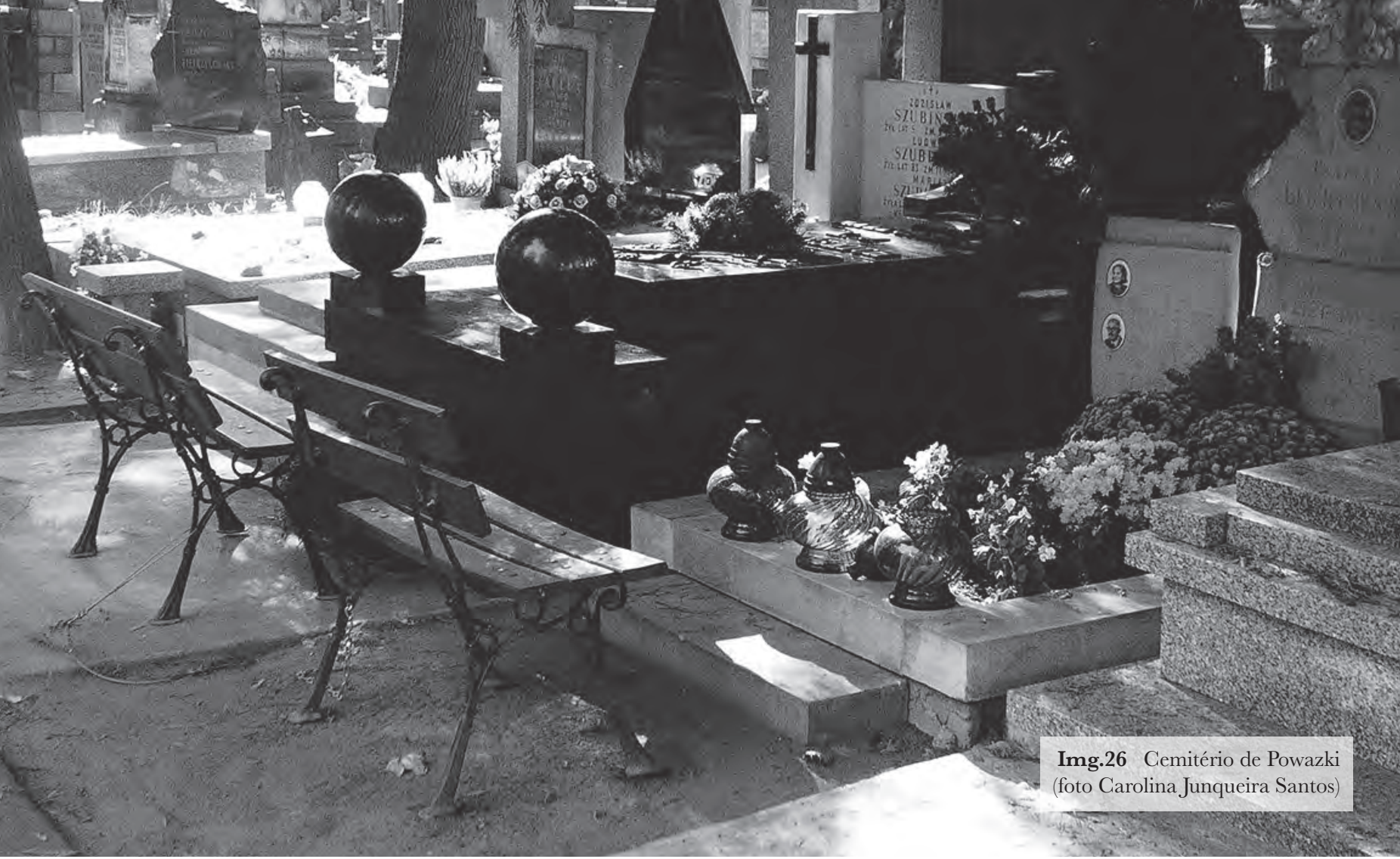

Nesse sentido, a relação entre a pessoa e o espaço pode ser transformada através da ideia de ambiência, como coloca Thiolliere. Para o autor (2016, p.280, tradução nossa) a ambiência é "um elo imaterial que engloba, em um espaço-tempo com fronteiras mais ou menos difusas, interações entre subjetividades, fluxos e um ambiente material.”. Desse modo, sob a ótica do luto, é fundamental pensar nos cemitérios como espaços capazes de abrigar e sustentar as variadas atmosferas de interação entre os vivos e os mortos. A compreensão da noção de ritmo e tempo suspensos coloca-se de modo significativo para o entendimento da necessidade de se distanciar, ao menos momentaneamente, das atividades e demandas da vida urbana acelerada ${ }^{65}$ para a elaboração da morte e da perda. Porém, ressaltase que isso não significa um isolamento estrito, mas a busca pelos pontos de contato entre os ambientes de vida, que deve ser seguida e retomada, e de morte, que deve ser compreendida e elaborada.

65

Constata-se que, atualmente, parâmetros como o tempo de licença do luto costumam ser definidos pela produtividade do trabalho e não pela necessidade de sua elaboração. 
Como forma de ajudar na compreensão dessa ideia, Thiolliere (2016) usa a imagem de bolha (bulle) como um mecanismo capaz de gerar um espaço-tempo particular. A bolha permite combinar, ao mesmo tempo, um processo íntimo com um encadeamento social. Ela proporciona tanto o recolhimento e a proteção necessários para o desenrolar da relação com os falecidos, como mantém o enlutado no âmbito social e no espaço material, deixando-o em contato com o meio social e urbano. No entanto, devido à fragilidade da bolha ${ }^{66}$, é essencial pensar um equilíbrio entre essas partes, de modo a garantir a importância de cada especificidade desse processo.

Por fim, é importante considerar que o luto não está restrito ao cemitério, mas acompanha o enlutado aonde ele for. Portanto, é fundamental pensar a experiência do luto como uma trajetória para além desses locais, de modo que os espaços onde a relação com a morte e os mortos se desenrolem não sejam isolados e desolados, mas mantenham um vínculo com a cidade e outros espaços urbanos. Ao se pensar nas formas como as relações entre os vivos e os mortos podem ser dadas, o espaço pode reforçar o sentido de busca por uma vivência que deve, aos poucos, ser estabilizada, contribuindo para a aceitação da perda e a mudança que ela implica.

66 Thiolliere coloca que um transeunte é capaz de explodi-la. 


\section{$\underline{\text { Pontos de acolhimento }}$}

As questões de memória, religiosidade e luto são fenômenos complexos e dinâmicos que envolvem uma relação com suportes materiais, espirituais e espaciais que, se forem concebidos com atenção às suas particularidades, podem atuar de maneira benéfica na forma de se relacionar com a morte e com os mortos. Para tal, ressalta-se que essas três ideias são bastante subjetivas e devem ser entendidas desta forma.

A memória reconhece as identidades, transmite histórias e valores, traz a sensação de continuidade do decorrer da vida. A religiosidade ajuda a lidar com o desconhecido, a dar significado a fenômenos de difícil assimilação, a imaginar que pode haver sentido em algo que vai além da compreensão humana. Por fim, o luto auxilia na reorganização e na retomada da vida, no encontro de uma nova estabilidade para a relação, ajuda a encontrar a resiliência. Entende-se que essas ideias são fundamentais para se refletir sobre percepção de amparo frente à situação de perda e separação que a morte proporciona, sendo importante pensar como os artefatos e os espaços podem atuar na sua assimilação. Juntas, elas conformam um tripé que visa possibilitar a reestruturação dos vínculos, estabelecendo novas formas de se lidar com a ausência e tecendo novos meios de relacionamento com o falecido.

Esse tema é desenvolvido por Hallam e Hockey (2001) em sua pesquisa sobre as relações das pessoas com os suportes à morte. Através da realização de etnografias junto aos visitantes de túmulos em cemitérios britânicos, elas constataram que os túmulos foram transformados em espaços nos quais os falecidos recebem visitantes e presentes, invertendo o sujeito das ações. Assim, ao fazer esse movimento, os falecidos passam a residir nestes locais, que ganham novo significado. Com isso, a relação estabelecida posiciona o morto no presente, compartilhando o tempo social dos vivos. Desse modo, as pesquisadoras constataram que "lidando com o trauma da morte, as pessoas (...) mobilizaram materiais e imagens domésticas comumente reconhecíveis para criar, como uma interlocutora chamou, "um lugar de beleza" (HALLAM E HOCKEY, 2001, p.152, tradução nossa). 


\section{Subjetividades: Polissemia e Paradoxo}

\section{Polissemia, temporalidade, subjetividade}

Para muitas culturas, o ato de entrar em um espaço de cemitério requer uma preparação e uma mudança de postura. Assim, é possível encontrar pessoas fazendo diversos gestos para esse momento, como escolher o pé "certo" para dar o primeiro passo no local, fazer sinais devotos, usar meios de proteção ou, ainda, realizar rituais formais como a lavagem das mãos. O sentimento não é igual ao de entrar em um lugar qualquer do dia a dia. De acordo com os significados dados ao cemitério, percebese que ele é entendido como um espaço diferente, um outro universo, outro lugar.

Essa percepção do ambiente de cemitério como algo distinto, é desenvolvida por Michel Foucault através da ideia de heterotopia ${ }^{67}$, do grego, hetero, de outro, e tópos, de lugar. Segundo Foucault (2011), ao contrário de uma utopia, que é somente virtual, a heterotopia é real ainda que, assim como a utopia, seja reflexo de uma questão imaginativa.

67 A ideia de heterotopia foi introduzida por Foucault pela primeira vez em 1966, no livro As palavras e as coisas. Posteriormente, em 1967, ela foi apresentada em uma conferência destinada a arquitetos, a partir do texto intitulado Os outros espaços (DEFERT, 2009). 
Para melhor entender esse conceito, o filósofo apresenta a ideia do espelho: do mesmo modo que se pode segurar um espelho físico, real, enquanto se olha sua imagem irreal projetada, a heterotopia é composta tanto pelo objeto em questão como por sua reflexão. Nesse sentido, a ideia da heterotopia se aproxima ao entendimento de lugar material e espaço simbólico ${ }^{68}$, conforme descritos por Michel de Certeau. Para Certeau (1996) o lugar é concreto, um cenário situado geograficamente e que, portanto, impede duas coisas de se situarem simultaneamente num mesmo ponto. Já o espaço, é impreciso, não é uma realidade física, é onde duas coisas poderiam se encontrar. Desse modo, a metáfora do espelho pode ser entendida através das ideias de lugar material (a fonte a ser refletida) e espaço imaterial (imagem refletida no interior do espelho). Ao enxergar o cemitério sob a ótica da heterotopia, é possível pensá-lo não apenas como propriamente o lugar onde são colocados os indivíduos falecidos, mas como um espaço onde as possibilidades semânticas se abrem à imaginação, trazendo os mais variados tipos de entendimento a seu respeito.

Junto a essa conjuntura polissêmica característica da

68 Destaca-se a distinção entre lugar e espaço como fundamento para a adoção do termo "espaços de cemitério" usado de forma recorrente nesta pesquisa, inclusive em seu título. Ressalta-se que ao diferenciar o uso dos termos "lugar" e "espaço", a ideia não é estabelecer uma normativa sobre o uso das palavras, mas melhor entender a discussão sobre a essência do cemitério. heterotopia, a percepção do espaço cemiterial também está atrelada à noção de outras temporalidades proporcionadas por sua capacidade de estabelecer tempos acrônicos. De um lado, a assimilação das vidas transcorridas no cemitério leva à projeção tanto das memórias passadas como do próprio destino da morte, deslocando o transeunte a um futuro indefinível. Por outro, a imagem de repouso dos mortos traz ao cemitério um sinal de imobilidade marcado por um rompimento com a demarcação do tempo, a sensação de suspensão temporal. Nesse sentido, Harrison coloca que:

\footnotetext{
“o túmulo inscreve na paisagem um lugar onde o tempo não pode simplesmente se contentar em passar. É justamente esse devir mortal do tempo que dá ao lugar seus limites articulados, distinguindo-o da infinitude do espaço homogêneo. Como o sinal primordial da mortalidade humana, a sepultura realiza a transcendência inumana do espaço e marca o tempo humano fora da atemporalidade divina e dos retornos eternos da natureza."
}

(HARRISON, 2003, p.23, tradução nossa) 
Assim, a conjunção espaço-tempo do cemitério e a presença difusa dos rastros que a morte oferece configuram as experiências singulares representadas por cada forma possível de se perceber o espaço e sentir o lugar ${ }^{69}$. Então, as diferentes percepções e sensações tornam o cemitério portador de múltiplos significados, condição característica das heterotopias. Desse modo, a aproximação dos cemitérios ao conceito de Foucault destaca as virtudes desses espaços-lugares que através das subjetividades, encontram-se abertos às mais variadas interpretações e sentidos.
69 Didi-Huberman desenvolve as ideias de "perceber o espaço" e "sentir o lugar" em seu livro Genie du non-lieu (2001). Ao analisar a obra Delocazione, de Claudio Parmiggiani, DidiHuberman desenvolve noção paralela à Michel de Certeau, onde o espaço está ligado às compreensões e possibilidades simbólicas, e o lugar está ligado ao exercício empírico, às sensações e qualidades materiais.

\section{Expressividade, dissimulação, paradoxo}

Como visto na parte I desta dissertação, a partir do momento que o espaço urbano do século XIX limitou a convivência entre vivos e mortos, o cemitério tradicional tomou para si a continuidade dessa relação, estabelecendo novas formas de contato através do culto aos expressivos e marcantes túmulos deste local. No entanto, com o passar dos tempos, surgiram outras configurações de cemitério, marcadas por uma maior simplificação e padronização nos meios de se representar a morte. O cemitério-jardim encontrou seu espaço, tornando-se símbolo de uma busca de ambientes de cemitério considerados mais aprazíveis e agradáveis. Desse modo, em uma relação tanto de oposição como de complementaridade, ambos perfis de cemitério passaram a conviver no cenário urbano.

Tendo em vista estabelecer um olhar crítico a respeito das características desses tipos de cemitério, para cada um deles surgem distintos questionamentos quanto às decorrências de sua configuração. Enquanto as construções tumulares do cemitério tradicional caracterizam uma condição explícita de diferenciação social, como visto no tópico (5) Expansão, a simplificação e padronização das sepulturas são vistas como uma atitude de ocultação em relação à morte, o seu 
silenciamento. Símbolo de uma sociedade baseada na produção em massa e na economia de escala, a simplificação é vista como uma tentativa de dissimulação que faz com que o cemitério deixe de ser o espaço de expressão da relação com a morte. Com isso em mente, Rodrigues critica o que considera a perda da identidade palpável desse local, que começa a se confundir com outros ambientes. Para ele, o cemitério "se fantasia de parques nos quais as sepulturas são discretas, nos quais a morte é maquiada e por isso dificilmente visível em sua verdadeira fisionomia" (RODRIGUES, 2006, p.172). Por outro ponto de vista, ao olhar para o contexto urbano de crescimento dos cemitérios-jardim, percebe-se que a expansão desse tipo de cemitério também está relacionada com um movimento de busca por mais espaços verdes junto às grandes cidades industriais, expandindo a reflexão sobre esses lugares para uma perspectiva urbana e ambiental. Nesse sentido, Baudrillard (1996) chama atenção para a contradição que representa o fato de os espaços fúnebres serem um dos poucos ambienteis vivíveis em cidades com altos índices de industrialização como Chicago.

Desse modo, mostra-se fundamental discutir sobre a conformação da representação da morte nos cemitérios a partir das diferentes formas de se entender a noção de simplificação. Da mesma maneira que ela pode ser entendida como um gesto de dissimulação da morte, ela também pode estar ligada a uma transformação formal dos meios de composição do espaço, a busca pela elementaridade das formas. $\mathrm{Na}$ arquitetura, uma das máximas mais difundidas durante o século XX foi justamente a ideia de que "menos é mais"70. Sob essa ótica, a simplicidade não deve ser vista como um gesto em direção à banalização, mas como uma busca pela essência. Então, a crítica deve ser direcionada aos casos onde a simplificação das representações constitui a sua eliminação ou algo muito próximo a isso. Assim, dentro de uma discussão entre forma,

70 Conceito associado ao arquiteto modernista Ludwig Mies Van der Rohe, um dos principais nomes da arquitetura minimalista e defensor do uso de linhas retas e formas simples. função e espaço, a dissipação da morte em um cemitério seria uma das maiores incongruências imagináveis. Do mesmo modo que não há lógica em construir uma biblioteca onde os livros não sejam acessíveis ou visíveis, também não deveria haver lógica em conceber um cemitério que tem como objetivo dissimular seus mortos. Nesse sentido, o comentário feito pelo arquiteto Adolf 
Loos encontra fundamento justamente na configuração de um sinal que marca o evento da morte: "se encontrarmos um monte na floresta amontoados com uma pá em forma de pirâmide, nos comportamos de forma solene e então algo nos diz: alguém está enterrado aqui, e isso é arquitetura" (LOOS, 1966, p.192).

Portanto, partindo-se do pressuposto de que as representações da morte são fundamentais, é essencial discutir como os artefatos fúnebres e a composição do cemitério podem atuar frente às questões colocadas pela morte. Para tal, ressalta-se que o papel do cemitério, em qualquer uma das circunstâncias discutidas, deve estar em simbolizar, contemplar um enredo de acolhimento dos traços da mudança decorrente da morte e manter a continuidade da relação com o ausente. Como coloca Louis-Vincent Thomas (1989, p.319, tradução nossa), "sua função [da lógica funerária do cemitério] não é só honrar os mortos, mas tranquilizar os vivos. Mas em suma, não é essa a função de todos os comportamentos que giram em torno do tratamento do cadáver?"

Em trabalho de campo realizado junto aos cemitérios britânicos, Francis, Kellaher e Neophytou (2000) buscaram entender porque as pessoas visitavam cemitérios, o que faziam durante suas visitas e o que esses espaços significavam para elas. Ao analisar suas conclusões, nota-se as diferentes maneiras pelas quais tenta-se articular o significado desses lugares. Foram encontrados uma variedade de significados, sendo que em muitos casos, na mesma interlocução foram colocadas visões ambíguas e contraditórias. O estudo observa, por exemplo, que o cemitério é, ao mesmo tempo, calmo e inquietante, público e íntimo, contínuo e transitório. Em outra escala, a mesma sensação pode ser percebida ao longo dos meses de incursão realizada nos cemitérios de São Paulo para esta pesquisa.

Assim, percebe-se que o cemitério é um espaço que possui qualidades difíceis de se descrever e, desse modo, será sempre objeto de controvérsias. Frente a isso, é fundamental conseguir aceitar e lidar com a condição inerentemente paradoxal destes lugares, ricos em ambivalências e contradições. 



\section{Interfaces: Coexistências, Limiares}

\section{Apropriações, conflitos e coexistências}

Se durante o período medieval o cemitério dava lugar a feiras, danças, jogos e encontros públicos, com a criação dos primeiros cemitérios modernos foram estabelecidos regulamentos que passaram a controlar as atividades permitidas aos moldes do que era comum no interior das igrejas. Ao falar sobre o surgimento dos cemitérios na Bahia, João José Reis conta que as autoridades eclesiásticas impunham regras de modo a inibir o que era considerado profanador desse campo santo:

"Sendo o Cemitério lugar consagrado pela Religião ao jazigo dos mortos, e por isso unicamente próprio para excitar sérias e religiosas meditações, são proibidos dentro do seu recinto todos os divertimentos e atos proibidos nos Templos, e conseguintemente tudo que for alusivo a paixões voluptuosas, e a poder despertar recordações ofensivas da decência, e da Moral Cristã, ou idéias de materialismo, que não vê além do Túmulo senão o nada."

(REIS, 1991, p.304) 
Desse modo, através do estabelecimento de normas de comportamento, as apropriações passaram a ser limitadas de forma a evitar que aqueles considerados libertinos e materialistas exercessem atividades vistas como inadequadas. Assim, a busca por uma correspondência entre o decoro e os usos dos espaços restringiu as possibilidades de intervenção nos cemitérios, desencorajando certos tipos de atividades. Os regulamentos de conduta, oficiais ou convencionados, definiram um sentido de aprovação ou desaprovação das atuações nesses lugares, agenciando-as segundo uma perspectiva moralizante e moralizadora característica do cristianismo.

Em alguns casos, esse posicionamento chegou a se manifestar inclusive na construção do lugar. No Mount Auburn, por exemplo, lembrava-se aos visitantes que eles eram vistos através da edificação de uma torre como ponto focal do lugar. Essa torre exercia uma dupla função de marco e observatório, atuando como uma espécie de pan-óptico ${ }^{71}$ do cemitério. Assim, ao mesmo tempo que os visitantes a viam, eles tinham a sensação de serem vistos, transformando o seu comportamento no espaço de cemitério. Embora grande parte desses lugares não tenha torres construídas, de algum modo, instaurou-se um "sistema de vigilância" em seus ambientes.

Fruto dessa postura, é comum a percepção de que as formas de apropriação e conduta consideradas alheias às questões fúnebres e religiosas são inadequadas ao espaço de cemitério. Prevalece o entendimento de que, nesse lugar, é preciso se comportar "devidamente", o que desencadeia toda a subjetividade do que pode ou não pode ser considerado "apropriado". Ao estipular posturas atreladas a uma forma específica de se portar e comportar no cemitério, percebe-se como, em certo sentido, os "dilemas morais" da sociedade em questão tornaram "dilemas espaciais" (LUSSAULT apud THIOLLIERE, 2016, p.296, tradução nossa).

71

O pan-óptico é um modelo desenvolvido por Jeremy Bentham, em 1785, onde é estabelecido um sistema de vigilância que permite observar todos os prisioneiros de uma penitenciária desde um único ponto de vista, sem que estes possam saber se estão ou não sendo observados. Na dúvida, o medo e o receio de estarem sendo observados leva-os a adotar a comportamento desejado pelo vigilante.

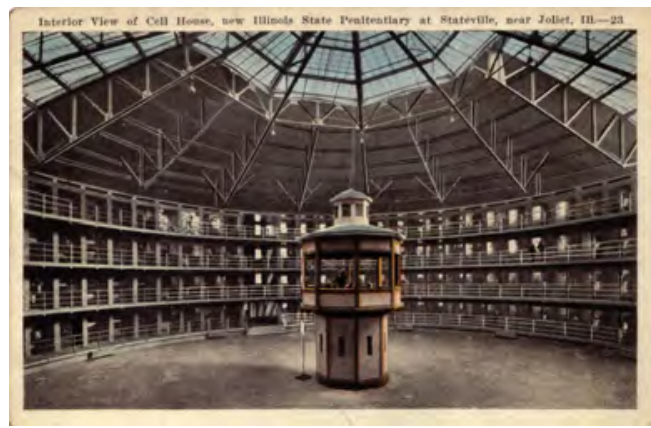

Img.28 Pan-óptico da Illinois State Penitentiary (mediastudies.it) 
No entanto, a partir da conjuntura despontada durante o século XX, o espaço cemiterial passou a abrigar novas formas de ação surgidas à revelia das expectativas e de aspectos morais estritos. Considerando o contexto dos cemitérios urbanos, em meio ao ritmo acelerado da vida nas grandes cidades, esses locais foram objetos de apropriações diversas, livres da influência de qualquer imposição normativa. Tomando como exemplo o Cemitério da Vila Formosa, em São Paulo, o geógrafo Eduardo Rezende (2000) retrata a presença de diversas atividades realizadas neste local durante os anos 1990, para além de aspectos fúnebres ${ }^{72}$. Entre elas, o autor descreve o local como sendo palco de brincadeiras com pipas, atividades físicas, consumo de drogas e até atos sexuais. As apropriações de espaços fúnebres também aparecem na pesquisa da arquiteta Aline Santos (2015), feita nos jardins do Crematório Municipal de São Paulo ${ }^{73}$, que são utilizados também para empinar pipas e para a realização de exercícios físicos, além de passeios com animais de estimação.

Logo, encontram-se em concorrência no cemitério tanto uma postura planejada para controlar as ações esperadas no local, como atos de apropriação não planejados, feitos à irreverência de qualquer forma de controle. Percebe-se, então, que a qualificação das ações no espaço não depende apenas dos limites estabelecidos, mas do grau de possibilidade que ela inclui. Formas inesperadas de apropriação surgem a partir das oportunidades encontradas, sendo preciso compreender os usos do espaço de cemitério de acordo com cada contexto. Para isso, é fundamental entender a condição dinâmica existente entre "materialidade e ação" (QUEIROGA, 2012, p.58). Como coloca Queiroga, não se pode resumir a questão do espaço a partir apenas de sua materialidade, deixando de lado suas apropriações, bem como não se pode atentar apenas para as ações, esquecendo sua materialidade.

72 Cf. Metrópole da Morte, Necrópole da Vida, Eduardo Coelho Morgado Rezende, 2000.

73 Cf. Morte e Paisagem: os Jardins de Memória do Crematório Municipal de São Paulo, Aline Santos, 2015. 
Assim, em contraste com o controle comportamental e moral que se buscou determinar no cemitério, se em um primeiro olhar a utilização do espaço cemiterial como local de lazer e recreação pode parecer inusitada, na prática, percebe-se como ela efetivamente já acontece nos espaços fúnebres há décadas. Nesse sentido, relembrando passagem do tópico (7) Cemitério de São Paulo, foi visto como o Município de São Paulo, através do Plano Diretor de 2014, incorporou a ideia de se requalificar as áreas dos cemitérios na perspectiva de ampliar as áreas destinadas ao lazer da população. Como nenhuma atitude prática foi tomada e o PDE-SP de 2014 não desenvolve os meios como isso seria feito, resta esperar para ver se isso significará um princípio de mudança no controle institucional desses espaços. Um caminho mais adotado até aqui tem sido a museificação de cemitérios com valor histórico, artístico e patrimonial. Nessa perspectiva, os cemitérios são entendidos como grandes galerias ao ar livre, contendo exemplares importantes de arquiteturas passadas e estilos esculturais. Pode-se citar como exemplo os cemitérios de Highgate, na Inglaterra, o Père-Lachaise, na França, o Recoleta, na Argentina, e o Cemitério Consolação, que utilizam o patrimônio artístico presente em seus espaços como atração museológica, preservando seus elementos culturais. Desse modo, eles ganham relevância nos circuitos turísticos e passam a ser usados como lugares de visitação histórica.

Nesse sentido, tendo em mente as condições existentes nos cemitérios paulistanos, não se trata de realizar uma apreciação sobre este ou aquele tipo de prática como ações transformadoras do espaço por si só. Na prática, mesmo nos casos discutidos, o espaço permanece pouco alterado. Sobre as atividades, percebe-se que parte considerável ainda são, com efeito, ações residuais ou restritas. Assim, busca-se aqui, antes de qualquer análise, reconhecê-las. Ao fazê-lo, ao aceitar sua espontaneidade, é possível discutir as conjunturas de cada situação e então imaginar formas de usufruto dos cemitérios de forma condizente à complexidade, à diversidade e às necessidades da vida e da morte numa cidade como São Paulo. Desse modo, percebe-se que as ocupações dos espaços de cemitério representam uma instigante fonte de indagações sobre devires urbanos, como coloca Guatelli. Nesse sentido, é preciso 
"lidar com o florescimento, cada vez mais frequente, de eventos, de acontecimentos, verificados nas mais diversas escalas, que parecem causar certos desajustes ao romperem com o originalmente proposto, por vezes subvertendo as representações históricas que lugares e formas possuem, 'excedendo', mediante da apropriação e utilização momentâneas, os usos e funções inicialmente previstos como mais apropriados e adequados para tais lugares e objetos."

(GUATELLI, 2012, p.31)

Assim, pode-se dizer que os cemitérios se configuram como espaços facultativos às diversas formas de uso. Por não possuir espaços de lazer e recreação ao alcance de todos, a população da cidade de São Paulo encontra em cemitérios arborizados e vegetados como o Vila Formosa, lugar para exercer essas atividades. Com isso, ela reinventa e amplia a compreensão considerada predominante do cemitério. No entanto, verifica-se que isso não ocorre de modo indiferente tanto por parte dos enlutados, como dos praticantes de atividades "não programadas". Nota-se que há uma espécie de adaptação de conduta nos cemitérios. Por exemplo, os ciclistas que frequentam o local evitam gritar para chamar o outro, posturas não assumidas em uma rua ou um parque. A multiplicidade de atividades em um mesmo espaço como o cemitério, ao mesmo tempo que cria oportunidades de releitura, pode também gerar conflitos entre percepções diferentes. Enquanto em alguns casos os enlutados demonstraram que a presença de outras atividades ajuda a retomar a "normalidade", em outros casos a concomitância entre um funeral e atividades de lazer é vista como infortúnio.

Nesse sentido, é importante trabalhar os pontos de contato entre os ambientes que lidam com a morte, buscando os meios pelo qual as coexistências podem acontecer de forma conciliadora. Para tal, é importante ter como referência as discussões correntes, como o caso do projeto Yolocaust. Idealizado pelo artista Shahak Shapira, o projeto consiste em uma série de fotomontagens feitas a partir de selfies sorridentes e com poses extrovertidas tiradas por visitantes do Memorial do Holocausto, em Berlim. Shapira alterou essas fotos substituindo a paisagem do memorial por imagens dos campos de concentração, fazendo uma crítica à conduta dessas pessoas no memorial. Enquanto alguns julgaram desrespeitosas as 
selfies, a exemplo do artista, outros, como Peter Eisenmann, arquiteto do memorial, se colocaram de forma menos adversa: "as pessoas tem pulado nesses blocos desde sempre. Têm tomado banho de sol, têm almoçado ali e me parece que isso está bem." ${ }^{\prime 74}$ Os cemitérios também estiveram envolvidos em polêmica similar devido à sua inclusão no Pokémon $G 0^{75}$ Em Arlington, no Estado de Virginia, o cemitério nacional passou a ser visitado por jogadores que buscavam as criaturas virtuais. Essa postura incomodou alguns frequentadores, o que levou a administração do local a proibir o jogo dentro das suas dependências por considerar que essa atividade não era adequada ao cemitério ${ }^{76}$.

Assim, percebe-se que do mesmo modo que não há consenso sobre a conformação do espaço e das representações fúnebres, também não há consenso sobre quais atividades são ou não apropriadas e apropriáveis nos cemitérios. Desse modo, novamente, é preciso lidar com as contradições apresentadas. O desafio reside, então, em encontrar conformidades para cada situação, no sentido de encontrar concordâncias possíveis entre as incongruências passíveis.

74 Trecho retirado da reportagem Yolocaust: how should you behave at a Holocaust memorial?, de Joel Gunter (BBC News). Tradução nossa. Disponível em <www.bbc.com/news/world-europe-38675835> Acesso em: 16 jan. 2019.

75 Pokémon GO é um jogo eletrônico de smartphone que através do sistema de posicionamento global (GPS) e da câmera de dispositivos compatíveis, permite aos jogadores capturar, batalhar, e treinar criaturas virtuais (pokémons) que aparecem nas telas de dispositivos como se fossem no mundo real.

76 Conforme reportagem People are now playing Pokémon Go at Arlington Cemetery, de Thomas Gibbons-Neff (Washington Post). Tradução nossa. Disponível em <www.washingtonpost.com/news/checkpoint/ wp/2016/07/12/arlington-national-cemetery-wants-people-to-stopcatching-pikachu-on-its-hallowed-ground/? noredirect=on\&utm _ term $=.56$ a52336dfe2> Acesso em: 16 jan. 2019. 


\section{Fronteiras, limiares e indefinição}

Tendo em mente as condições paradoxais e contraditórias presentes nos espaços de cemitério, os conceitos de limites e limiares se apresentam como meios importantes para se discutir possíveis concordâncias. O arquiteto grego Stavros Stavrides, em seu livro Towards the city of thresolds (2010) se pergunta se uma "cidade de limiares" poderia ser o equivalente urbano a um projeto social de coesão, baseado na negociação entre diferentes identidades, de forma a construir coletivamente o futuro. Assim, Stavrides propõe uma reflexão sobre a necessidade de imposição de fronteiras. Para ele, ao mesmo tempo que esse ato é um fenômeno natural, fruto da necessidade e do desejo por proteção e sobrevivência, as fronteiras também são criadas justamente para serem atravessadas.

O principio para desenvolvimento dessa concepção está presente em um texto de Georg Simmel intitulado A Ponte e a Porta, escrito originalmente em 1909. Nele, o sociólogo alemão definiu o homem não apenas como um "ser-fronteira", mas também um ser "que não tem fronteiras" (1996, p.15). Para Simmel, a ponte representa a vontade de juntar espaços, ela supera o distanciamento entre extremidades ao mesmo tempo que as torna perceptível. Já a porta elimina a separação entre os espaços e, portanto, é capaz de ilustrar de maneira mais clara que a separação e a união nada mais são do que aspectos do mesmo evento. Dessa forma, Simmel (1996, p.15) constrói a ideia de que o ser humano tem "a possibilidade de quebrar os limites a qualquer instante, para ganhar a liberdade". Para ele, a porta é justamente a imagem do ponto fronteiriço onde o ser humano determina sua permanência.

Derivada das metáforas de Simmel vem a noção de soleira, usada de modo a entender a ideia de espaços limiares. A soleira é um elemento construtivo, usado sob a porta, de forma a marcar uma transição entre ambientes. Por estar localizada entre os limites desses ambientes, ao mesmo tempo que marca a separação e a passagem entre eles, a soleira é parte destes dois ambientes. Entre limiar e passagem, ela pode abrir-se a possibilidade de surgimento de um outro ambiente no encontro dos espaços. Portanto, assim como a soleira, o espaço limiar pode ser constantemente atravessado, oferecendo uma experiência de mobilidade e de permanência. É possível, então, usar o conceito de soleira como meio de evocar os momentos que marcam uma mudança de percepção e sensação, momentos limiares, que ampliam o entendimento e a compreensão do espaço. 
Essa noção permite investigar aspectos das dimensões social e temporal na experiência espacial, suscitando questões íntimas e simbólicas a respeito da percepção do corpo em relação ao ambiente em que ele está inserido. O conceito de soleira tem aparecido como uma das principais formas de discutir as atmosferas arquitetônica e urbana em um contexto cada vez mais múltiplo e diverso, sendo capaz de acolher variadas correspondências através das ideias de coexistência e convivência. Mostrar como a experiência móvel urbana emerge sobre os limiares e atmosferas, leva a questionar os possíveis intervalos em uma cidade que se quer cada vez mais aberta e flexível, capaz de acolher a multiplicidade e a pluralidade. Nesse sentido, o limiar indica um caminho entre as diferenças, um entre-percepções, entre-estados, entre-espaços, o que permite ao indivíduo ter um vislumbre de ambos os lados e, assim, oferece possibilidades de escolha, de mediação (THIOLLIERE, 2016).

No entanto, isso não significa que qualquer espaço possa tornar-se um espaço limiar. Para que esse processo seja viável, ele deve ter certas qualidades, deve ser capaz de despertar sensações e acepções distintas, características da heterotopia. O conceito de liminalidade pode ser interpretado como um recurso para as tensões existentes nos interstícios de um mesmo espaço pois, ao mesmo tempo que marca as diferenças, ele permite que ambas coexistam. Assim, tendo como pano de fundo um contexto urbano dinâmico, é possível apreender, em um mesmo espaço, a ligação afetiva individual com um ente querido falecido e a questão coletiva social envolvida na problemática da morte.

Ainda nesse sentido, através do reconhecimento de uma condição processual e transitória, é possível associar a ideia de limiar ao luto. Para tal, é preciso ter em mente que este último corresponde a uma situação em constante andamento, isto é, um fenômeno temporal em direção à aceitação da perda que busca encontrar algum caminho para se lidar com a ausência. De forma similar, o limiar pode ser visto como um meio essencial para se conceber uma experiência humana espaço-temporal, a existência como um processo rítmico, um caminho que envolve escolhas e, portanto, perdas. Ambos demandam uma interação com as transições que se apresentam, uma conciliação entre significados, percepções e atmosferas. Tanto o luto como o limiar falam do meio-termo, do espaço-tempo de transição, através do qual é possível sentir a tensão entre intimidade-interiorização e exposição-exteriorização Nesse meio-termo, tanto o limiar como o luto podem revelar um caminho para convivência entre o íntimo e a alteridade (THIOLLIERE, 2016). 
Assim, tendo em vista favorecer a concepção de limiares espaciais, é possível discutir como permitir condições e situações espaciais no qual esses eventos podem despontar. Nesse sentido, como proposto por Guatelli (2012), cabe refletir se poderia existir uma circunstância onde é possível constituir as adequações e pertinências espaciais, ao mesmo tempo em que se aceita e acolhe as formas inesperadas de uso e apropriação do espaço. Desse modo, o aspecto fundamental do cemitério como espaço fúnebre segue mantido, ao mesmo tempo em que se volta à reflexão de como um cenário limiar pode ser estabelecido. Em outras palavras, tendo em mente que a condição fúnebre está vinculada às definições idealizadas dos usos "adequados" ao cemitério, cabe refletir como ela poderia se constituir de forma não hermética, de modo a aceitar a mobilidade e diversidade de seus atributos. Ressalta-se, no entanto, que essa busca não representa a configuração de lugares "isentos" de propriedades, mas passíveis de conformidade.

A intenção, então, não deve consistir em retirar qualidades que fazem um cemitério ser identificado como tal, mas pensar meio de permitir que a profusão de ações convivam mesmo elas sendo, por vezes, paradoxais, justamente por não serem planejadas ou esperadas. Assim, o espaço se apresenta, ao mesmo tempo definido (como espaço fúnebre) e indefinido (pela forma como são determinadas as ações no espaço). Desse modo, tendo como pano de fundo a consideração de condições subjetivas, paradoxais e sincrônicas, essa indeterminação buscar reconhecer o espaço de cemitério tanto em sua complexidade relacional, como em seu contexto na cidade e sociedade contemporâneas. Assim, o princípio de limiar encontra sentido justamente na conformação de espaços “"em condições’ de assimilar as constantes e diferentes interrogações e requisições que eventualmente possam surgir" a partir das circunstâncias dadas (Guatelli, 2012, p.33).

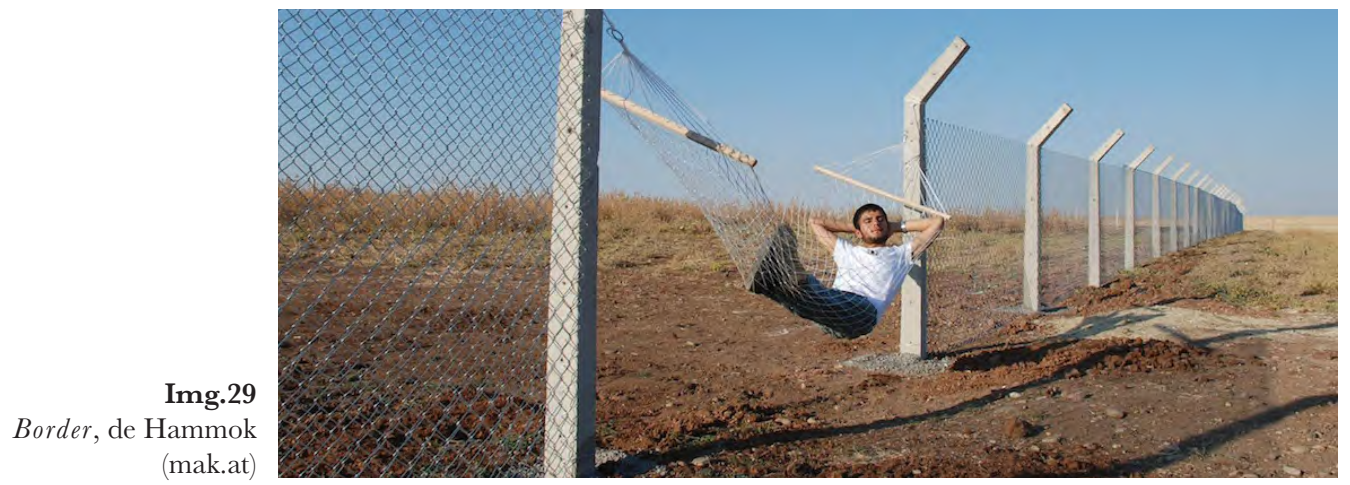





\section{Parte III}

Possibilidades e Desígnios 



\section{Rumos e Vestígios}

$\underline{\text { Rumos dos espaços fúnebres contemporâneos e a relação entre vida e morte }}$

A relação entre vivos e mortos varia de acordo com os costumes e pensamentos de cada época sendo, portanto, fruto de uma construção social. Assim, por mais que possa parecer um fenômeno estático e definitivo, de tempos em tempos ela acaba sendo transformada. Ao vasculhar a história dessa relação, é possível encontrar diferentes formas de relacionamento, às vezes de maior distância, às vezes de maior proximidade. Na Parte I foi visto que a última grande transformação dessa relação no mundo ocidental foi marcada pela separação entre a Igreja e os Estados modernos. A partir dessa cisão, desenvolveram-se aspectos que configuraram um escamoteamento da morte e dos cemitérios em relação à vida cotidiana e às cidades. Mais de dois séculos passados do início desse movimento, esse distanciamento segue dominante, estabelecendo uma espécie de oposição entre vida e morte. No entanto, nas últimas décadas percebe-se como tem crescido o interesse e os estudos sobre a morte, colocando em xeque esse escamoteamento e trazendo ao debate outras perspectivas sobre as formas que se dão a relação entre 
vida e morte. Desse modo, a visão majoritária de ocultamento dos cemitérios tem sido gradativamente questionada, passando a ser vista por alguns estudiosos mais como "um segredo muito mal mantido" (WORPOLE, 2003, p.8) do que um tema absolutamente negado e banido.

Efetivamente, ao observar as formas de relação com a morte em alguns países como a Alemanha e a Inglaterra, parece que este "segredo" está sendo cada vez menos guardado, o que é refletido nas transformações que alguns espaços funerários estão atravessando. Muitos cemitérios têm sido adaptados e redefinidos de modo a reconsiderar os meios de suporte à morte e sua relação com as sociedades urbanas. Começam a ganhar espaço perspectivas que confrontam uma visão individual da morte e que buscam se aproximar de uma concepção mais holística da passagem na Terra. Discute-se como conciliar as questões logísticas e econômicas aos aspectos ecológicos e humanistas. Projetam-se edifícios para abrigar os restos mortais junto aos meios urbanos adensados. A partir do desenvolvimento de novas tecnologias, surgem novos métodos para lidar com o cadáver. Com isso, os meios de constituição da relação com os mortos assumem novas formas e o tema da morte mostra os primeiros sinais de uma reconfiguração que ainda está por ser melhor definida.

Parece certo que o cemitério, visto como objeto urbano imutável, deve se transformar nas próximas décadas. Devido a fatores como o crescimento populacional, a transformação das formas de relação com os mortos, a mudança nas escolhas de tratamento do corpo e a nova conjuntura urbana, muitos cemitérios foram ou têm sido objetos de reflexão sobre essa forma e aspectos. Assim, algumas alternativas têm aparecido para se pensar os seus espaços: a preservação de cemitérios históricos e de valor patrimonial; a expansão de setores ou de áreas específicas; a reconfiguração de cemitérios existentes; e a abertura para outras formas de tratamento do corpo e de uso dos espaços.

O debate para se pensar os espaços fúnebres passa, então, pelo desafio de encontrar formas de abrigar as novas relações e posições junto à morte. Para isso, é preciso buscar configurações que, de acordo com cada contexto, permitam tanto a identificação dos temas relacionados à morte como sua apropriação pelas pessoas. Junto a outras áreas de estudo, a participação dos arquitetos na criação e organização desses lugares da morte é fundamental. É essencial caminhar em reciprocidade com a 
sociedade e com as experiências prévias, de modo a diminuir a lacuna entre as intenções de projeto e efeito prático. $\mathrm{O}$ arquiteto não transforma as relações, mas pode dar forma às mudanças em curso. Trata-se de testar os limites da arquitetura, do paisagismo e do design para descobrir os melhores meios para se contribuir na configuração da relação entre morte, sociedade e cidade. Ressalta-se ainda o papel da Universidade, que através da realização de pesquisas busca responder a questões de interesse da sociedade de forma transformadora. Nesse sentido, do mesmo modo que o discurso científico é reflexo das mudanças sociais, através de uma posição questionadora e, no caso da arquitetura, propositiva, ele pode também ser motivador e propulsor de mudanças.

Com isso em mente, serão discutidos na sequência procedimentos e projetos que podem, de modo geral, servir de ferramenta para se discutir as relações entre vivos e mortos colocadas pelo desenvolvimento material, espacial e urbano de uma sociedade contemporânea que se encontra em constante transformação.

\section{$\underline{\text { Vestígios }}$}

Para além de questões simbólicas, religiosas, memoriais e afetivas, a morte se apresenta como uma questão material. $\mathrm{O}$ corpo se torna vestígio e é preciso buscar uma destinação, uma forma e um lugar para acomodá-lo. Cada uma das escolhas envolvidas nesse processo acaba por estabelecer um tipo de relação com a morte e com o espaço. As práticas mais usuais de destinação do corpo são o enterro e a cremação. O enterro, como visto até aqui, está fortemente atrelado à questão de localização, tendo como ponto de apoio principal os cemitérios. Mesmo sendo um dos meios mais tradicionais e mais utilizados, outras formas têm ganhado lugar e importância, com destaque para a cremação, que se expande no mundo ocidental desde o começo do século XX. Assim, os cemitérios começaram a ampliar as formas de inscrição dos corpos falecidos nos espaços. A cremação se tornou a maior representante de meios que seguem uma linha de intervenção no processo orgânico de decomposição do corpo. Ela pode 
ser caracterizada como uma técnica funerária que visa reduzir um corpo a cinzas através da queima do mesmo, acelerando o processo de desfazimento do cadáver e substituindo as transformações biológicas por um procedimento culturalmente controlado. Prática bastante antiga, ela possui muitos adeptos e opositores que apresentam variados argumentos a favor e contra sua utilização.

Segundo Valérie Souffron (1999 apud THIOLLIERE, 2016), a escolha da cremação representa uma revolução mental que diz respeito tanto ao indivíduo quanto à sociedade, refletindo um desejo de controlar a própria vida até os últimos momentos. Entre os argumentos mais tradicionais a seu favor, há aspectos ligados à saúde e à higiene, baseados na ideia de que a cremação limita o processo de putrefação do corpo e evita possíveis contaminações derivadas do necrochorume. Além destes argumentos, com o passar dos anos, as razões para a escolha da cremação passaram a abrigar questões de ordem econômica, logística e ecológica. Muitos optam pela cremação como meio de minimizar os cuidados que o túmulo representa e evitar os custos constantes de sua conservação. Também, em locais que passaram por grande crescimento populacional, a cremação encontra na otimização dos espaços um importante aliado contra a falta de áreas de sepultamento e a superlotação dos cemitérios.

Por outro lado, ao mesmo tempo que pode ser entendida como um meio significativo para se lidar com a falta de espaço nas cidades, a cremação também é questionada por desconsiderar a importância do espaço dos mortos em favor do valor atribuído às terras. Nesse sentido, ela é vista como uma das grandes contribuintes para a decadência do culto das sepulturas e das visitas aos cemitérios. Ziegler (1977) aponta que a sociedade mercantil, na ânsia de maximização da renda imobiliária, encontrou na cremação uma solução para ganhar espaço urbano através de uma lógica de não desperdício de terras. Desse modo, entre os principais argumentos contra a cremação está o fato de que ela se desfaz do corpo de uma forma redutora, ou até exterminadora segundo 
alguns pontos de vista. Entre os principais nomes que adotaram uma postura crítica em relação a esse procedimento destaca-se Jean-Didier Urbain que a descreveu como um agente de desaparecimento literal e metafórico do morto. Para ele, a cremação é a "morte do morto" (1978, p.445, tradução nossa). Também contrário à cremação, Worpole (2003) destaca o entendimento de que ela possui um caráter demasiado industrial, representando os piores aspectos de uma cultura mecanizada e excessivamente racionalizada que é capaz de adotá-la como forma de aniquilação de narrativas e traços sociais ${ }^{77}$.

Nesse sentido, é preciso refletir sobre o papel das inscrições e remanescências para além da materialidade do corpo por si só, considerando também as formas de representação da memória ${ }^{78}$. Assim, para além do binômio enterro-cremação, ao se desenvolver a discussão sobre a destinação dos vestígios da morte, é preciso ter em mente que o ser humano não lida com a aniquilação. Essa interpretação tem ganhado espaço nas pesquisas sobre a morte ${ }^{79}$, baseada na concepção de que a cremação não visa a exterminação do corpo, mas a sua transmutação. O próprio Urbain, em artigo publicado nos anos 2000, aponta para uma revisão de sua posição ao dizer que a cremação não funcionaria somente dentro da lógica de destruição dos restos mortais, mas poderia permitir a conservação dos traços do falecido e o trabalho da memória através de um novo pacto ritual (SANTOS A., 2014).

77 Worpole lembra que, para algumas comunidades, a cremação remete à incineração em massa realizada nos campos de concentração nazistas durante a Segunda Grande Guerra (1939-1945).

78 Mesmo a prática do enterro pode acabar por ocultar ou desvalorizar as representações da morte, como foi visto no caso dos cemitérios gramados.

79 Foi visto no tópico (8) Morte, Ausência, Semiótica como autores como Edgar Morin e Hans Belting reforçam o entendimento de uma continuidade do falecido através da imagem e do duplo, o que também funciona para sua conversão em cinzas. Assim, mesmo em situações traumáticas, onde o corpo acaba desaparecido, é comum a busca por substitutos a ele, reforçando a ideia desenvolvida da presença de uma ausência. 
Observa-se, então, que não há uma visão unilateral sobre o tema, estando ela atrelada às mudanças de percepção ao longo do tempo. Efetivamente, elogios e críticas à parte, muitos países viram um aumento considerável na adoção da cremação durante o século XX, sendo que em alguns lugares ela passou a ser adotada de forma majoritária. Os processos para entendimento da sua expansão são bastante complexos e não podem ser explicados de forma linear ${ }^{80}$. Ainda assim, possivelmente sob influência da oposição da Igreja Católica à prática ${ }^{81}$, esse crescimento tardou a se iniciar no Brasil. No entanto, desde os anos 2000, ela tem crescido consideravelmente nos centros urbanos. Na cidade de São Paulo, por exemplo, o serviço cresceu aproximadamente $3000 \%$ desde que foi iniciado, sendo que somente entre os anos de 2005 e 2011 deu um salto de aproximadamente 59\% (SANTOS A., 2015). Se nos anos 1990 havia apenas 2 crematórios no Brasil, em São Paulo e no Rio de Janeiro, em 2018 já era possível encontrar mais de 60, distribuídos em todas as regiões do país ${ }^{82}$.

Assim, considerando o grande crescimento da prática da cremação, mostra-se importante pensar sobre sua relação com os espaços para além do ponto de vista de otimização das áreas, afinal, a cremação é o método de tratamento do cadáver, e não a sua destinação final. A opção pela cremação envolve uma segunda escolha: a definição do itinerário das cinzas. Nesse sentido, a forma mais usual é o seu armazenamento em urnas cineárias. Estas, por sua vez, podem ser colocadas em columbários, junto aos túmulos ou transportadas a locais de importância pessoal, configurando um gesto de conservação dos restos mortais. Outro caminho que busca a preservação das cinzas, é o seu próprio enterro. Em São Paulo, esse movimento pode ser encontrado nos jardins do Crematório Municipal, onde se percebe uma espécie de mescla com os costumes presentes no cemitério através da criação e manutenção de jardins de memória (SANTOS A., 2015).

80

Nesse sentido, é importante observar que além de questões religiosas, outros fatores estão envolvidos, como pode ser percebido pela baixa adoção de cremação nos Estados Unidos, país de cultura protestante. Worpole (2003) esboça algumas razões, porém elas são mais reflexivas do que técnicas, sendo ainda necessário a elaboração de estudos específicos para melhor compreender a adoção ou rejeição da cremação em cada situação.

81

A aceitação da cremação pela Igreja Católica ocorreu somente em 1963 através da Congregação do Santo Ofício (Instrução Piam et constantem, de 5 de julho de 1963 - AAS 56, 1964, p.822-823)

82

Conforme Mapa de crematórios do Brasil disponível em <www.urnasdeangeli.com.br/ cremacao/mapa-crematorios> Acesso em: 14 jan. 2019. 
Seguindo um roteiro distinto, outra forma de destinação das cinzas é a sua dispersão ou espargimento. Essa prática tem se tornado comum no contexto europeu ${ }^{83}$, principalmente desde o final do século XX (SOUFFRON, 1999 apud THIOLLIERE, 2016). Worpole (2003) acredita que parte do crescimento do espargimento está relacionado ao aumento de uma falta de empatia pela configuração dos cemitérios, o que leva as pessoas a encontrar outros locais para este propósito. Normalmente, procura-se lugares associados à memória da pessoa ou até mesmo solicitado por elas: uma paisagem natural, um lugar de infância ou até as dependências da equipe de futebol predileta. Nestes casos, o destino das cinzas deixa de ser associado a um ponto geograficamente determinado, à semelhança do túmulo, e expande-se simbolicamente para um lugar ou um corpo.

Assim, a dispersão das cinzas favorece a ideia de nomadismo, estabelecendo outra forma de relação com os mortos, menos localizadas e mais difusas. No entanto, embora esse movimento possa ser entendido como um decréscimo do monumento fúnebre como ponto de representação, ainda é fundamental o papel do lugar e dos signos materiais ou corporais que são articulados em relação com a morte. Eles são peças-chave no desenrolar dos processos de memória, religiosidade e luto. De forma alguma a dispersão deve ser entendida como um gesto de extermínio, mas como um movimento de associação. Esse gesto pode ainda ser entendido como uma entrega a um ambiente ou lugar. Nesse sentido, destaca-se a história contada por uma amiga que decidiu por espargir as cinzas da avó no rio de sua cidade de nascença. Ao fazê-lo, ela relatou que o corpo do rio se tornou, de alguma forma, representativo da presença da avó, dando um novo significado tanto ao rio quanto às cinzas.

Em um sentido paralelo a esse, mas voltado especificamente para questões do ambiente natural, desde o final do século XX tem ganhado espaço um movimento em direção a uma maior conscientização das questões ecológicas. Refletido inicialmente nas práticas durante a vida, ele tem alcançado cada vez mais o tema da morte e do corpo, trazendo práticas funerárias que unem a tecnologia à problemática ambiental. Neste caso, mesmo a cremação, entendida como uma opção mais ecológica em comparação ao enterro, passa a ser vista com ressalvas devido aos altos índices de energia que consome e os gases poluentes que emite. 
Desse modo, contrapondo-se tanto ao enterro como à cremação, essa perspectiva favorece o tratamento do corpo como biomassa, uma substância que deve ser decomposta ou reciclada do modo mais eficiente e sustentável possível. Os novos métodos desenvolvidos partem da ideia de mimetizar a matéria corporal com ambientes orgânicos ou, ainda, de aproveitá-la para gerar energia. Processos como a promessa ${ }^{84}$, a hidrólise alcalina ${ }^{85}$ e a biometanização ${ }^{86}$ se apresentam como alternativas para aqueles que buscam um processo controlado de decomposição do corpo, ao mesmo tempo que manifestam uma preocupação com o futuro ambiental do planeta.

Um exemplo paradigmático dessa linha de raciocínio é o projeto Recompose ${ }^{87}$. Pensando na problemática dos grandes centros urbanos, o projeto tem como princípio a compostagem dos restos, transformando-os em solo fértil que pode ser usado no plantio de vegetação em parques, jardins ou hortas. Se em um primeiro momento esses métodos podem parecer estranhos ou inapropriados, para seus defensores ${ }^{88}$ sua aceitação pode ser mais rápida do que a da cremação, pois o procedimento de cremação representa, na prática, um ato bastante agressivo para com o corpo ${ }^{89}$. Às suas maneiras, cada um desses novos métodos tem como objetivo minimizar as ações artificiais através do estímulo à mudança dos dispositivos existentes no campo funerário, trazendo formas de decomposição relacionadas ao incentivo de fenômenos naturais.

84 A promessa é um processo criado em 1999 pela bióloga sueca Susanne Wiigh-Mäsak que envolve cinco passos: congelamento do corpo por imersão em nitrogênio líquido; vibração do corpo congelado; processamento à vácuo para que o gelo sublime para diminuição do peso em até 2/3 do original; colocação do restante das partículas em um caixão biodegradável; e enterro em camadas superiores do solo, onde as bactérias aeróbicas decompõem os restos em até 1 ano. Cf. <www.promessa.se>

85 Além do termo hidrólise alcalina, este procedimento encontra diferentes nomes, de acordo com a empresa que o realiza. Ele ainda pode ser chamado de Water Resolution, Natural Cremation, BioCremation ou Resomation. De forma geral, ele consiste em uma cremação química que usa calor e pressão para reduz o cadáver a um líquido dispensável e uma pequena quantidade de resíduo ósseo seco ou cinza mineral

86 Também chamada de digestão anaeróbia, este método consiste no uso de microrganismos que passam a consumir a matéria orgânica na ausência de oxigênio. Ele é mais conhecido por seu uso como fonte de energia renovável através da gestão orgânica dos resíduos sólidos urbanos.

87 Cf. <www.recompose.life>

88 Katrina Spade, a criadora do Recompose defende esse e outros pontos em diversas publicações e vídeos que podem ser encontrados na internet. Cf. <www.youtube.com/watch?v=bnvnBwP9sTo>

$89 \mathrm{Na}$ cremação o corpo falecido é introduzido em um forno a cerca de $700^{\circ} \mathrm{C}$ e os restos não incinerados, como os ossos, são esmagados mecanicamente. 
Assim, tendo em mente que os processos de tratamento em relação à morte representam transformações significativas na perspectiva social e cultural, resta aguardar para ver se as novas formas alternativas de manuseio do cadáver encontrarão lugar. Nesse sentido, é importante ressaltar que as novas técnicas não devem ser entendidas como substitutas de procedimentos sociais e históricos estabelecidos em relação à morte, mas como recursos para a conjuntura contemporânea, como alternativas. Percebe-se que há um progressivo encaminhamento das escolhas de destinação do corpo para o campo das aspirações e convicções pessoais. A morte se torna cada vez mais ligada às peculiaridades e preferências de cada pessoa ou grupo identitário. Com isso, diminuem as restrições a um ou outro ritual padrão, de modo a permitir que a memória, a religiosidade e o luto se expressem pelas sensibilidades de cada situação.

Assim, a multiplicidade de métodos de destinação do corpo não deve representar uma anulação dos espaços de cemitério, mas impulsionar sua reinvenção. Desse modo, o desafio para se pensar esses lugares reside em imaginar como eles podem abrigar tanto os métodos corriqueiros, como os que tem surgido. A problemática da morte, em sua essência, segue sendo a mesma: lidar com a transformação da natureza, dos traços e da sobrevivência, afinal, são os vestígios que traduzem a reverberação da morte.

\begin{tabular}{|c|c|c|c|c|c|}
\hline & SEPULTAMENTO & GREMAÇÃO & $\begin{array}{l}\text { HIDRÓLISE } \\
\text { ALCALINA }\end{array}$ & PROMESSA & BIOMETANIZAÇÃO \\
\hline 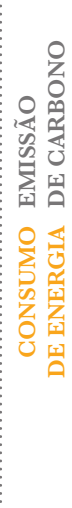 & 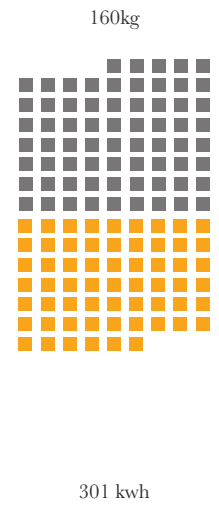 & 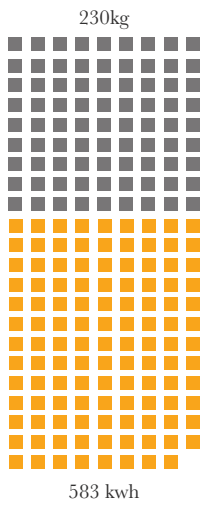 & 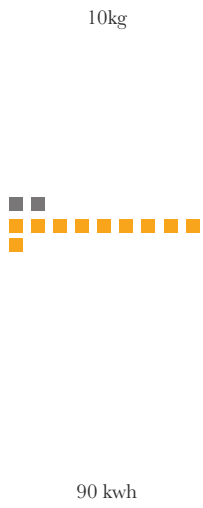 & 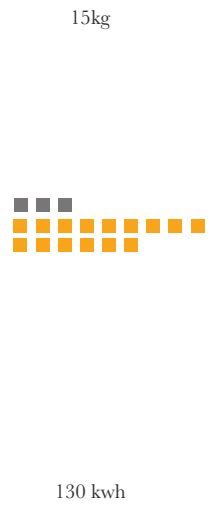 & $\begin{array}{c}\text { O METANO } \\
\text { PRODUZIDO } \\
\text { PELO PROCESSO } \\
\text { PODE SER } \\
\text { COLETADO E } \\
\text { UTILIZADO } \\
\text { PARA PRODUZIR } \\
\text { ENERGIA } \\
\text { ELÉTRICA OU } \\
\text { BIOGÁS }\end{array}$ \\
\hline
\end{tabular}

Img.30 Comparação de consumo energético e emissão de carbono por método de tratamento do corpo (diagrama feito pelo autor com dados retirados de deathlab.org) 



\section{Perspectivas}

\section{$\underline{\mathrm{O} \text { retorno à natureza }}$}

A presença de vegetação nos cemitérios do século XIX serviu a dois propósitos principais: favorecer os aspectos de salubridade e evocar a ideia de natureza. Desse modo, inaugurou-se no período todo um repertório de cemitérios verdes vistos anteriormente: campestre, gramado, jardim. Assim, ao mesmo tempo que a vegetação reforça um senso de natureza, essa associação pode ser entendida como um movimento simbólico de retorno à natureza, representado principalmente pela concepção de jardins. A relação de espaços fúnebres com os jardins encontra-se no imaginário popular, remetendo a histórias sagradas e míticas. Michael Laurie (1983) afirma que muitas crenças religiosas descrevem o início dos tempos ou o término da vida em jardins ou paraísos. A própria definição da palavra em idiomas como o inglês, garden, remete ao mito do éden, o paraíso judaico-cristão $0^{90}$. Portanto, os sentimentos de paz e tranquilidade, comuns na percepção dos cemitérios-jardim, representam um encontro com a ideia de uma natureza mítica, evocada através da associação do jardim ao local de repouso dos mortos (SANTOS A., 2014).

90 A etimologia de garden está associada aos termos hebraicos: gan, que significa proteger ou defender; e oden ou $e$ den, que quer dizer prazer ou deleite (LAURIE, 1983). 
O começo do século XX, no entanto, trouxe uma outra forma de entender esse retorno à natureza, representado pelo estabelecimento do chamado Skogskyrkogården ou, em tradução do sueco, cemitério floresta. Localizado próximo à Estocolmo, o lugar foi inaugurado em 1920, fruto de um concurso ganhado pelos arquitetos Gunnar Asplund e Sigurd Lewerentz cinco anos antes. Criado em uma antiga pedreira, o Skogskyrkogården ocupa uma extensa área de 100 hectares, tendo sido planejado para atender uma demanda à longo prazo por espaços de sepultamento para os moradores de Estocolmo.

Buscando uma mudança na forma de organizar os cemitérios, Asplund e Lewerentz introduziram um tipo distinto de cemitério, nem tradicional, nem jardim. O Skogskyrkogården representou um novo cenário fúnebre, caracterizado pela presença de bosques de pinheiros onde estão localizadas dezenas de milhares de sepulturas. Estas, por sua vez, têm seu tamanho limitado de modo a favorecer o efeito geral do cemitério em detrimento de aspectos individuais. Esse ambiente, marcado pela conjunção entre os túmulos e as árvores, trouxe uma nova imagem de cemitério, conformando leituras e percepções singulares na relação com a morte ao trazer um novo entendimento da relação com o espaço verde do cemitério.

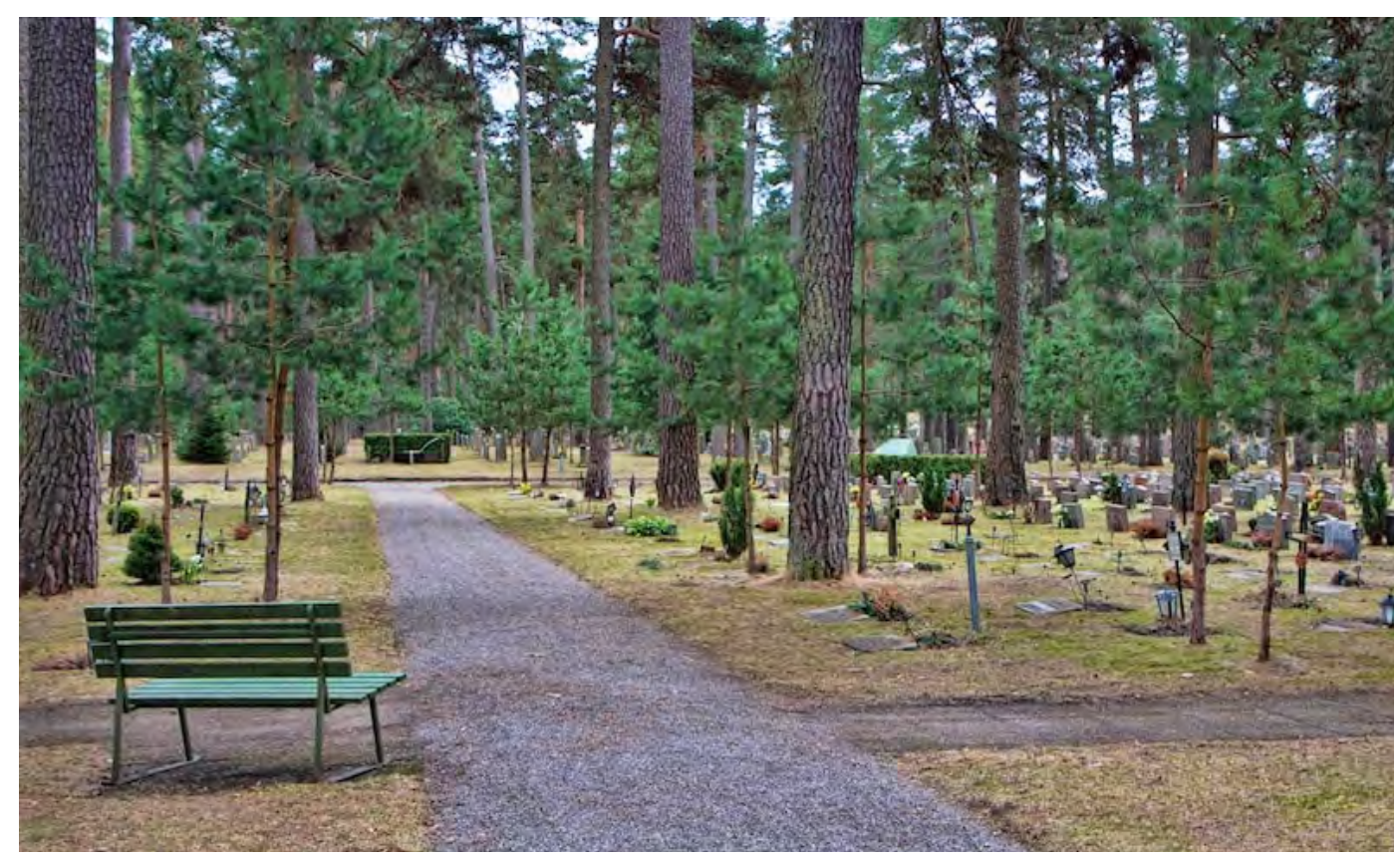

Img.31 Skogskyrkogården (ottsworld.com) 
O arquiteto paisagista Thorbjörn Andersson (1998) observa que, para os suecos, o paraíso não é representado pela imagem de um jardim idílico, mas é encontrado em uma natureza indomável. A palavra sueca para floresta skog, tem raiz na palavra islandesa primitiva para abrigo. Nas culturas escandinavas, a floresta é o lar original do mundo humano. Desse modo, a floresta, para os escandinavos, apresenta-se em contraposição à tradição do sul da Europa, onde ela é um lugar de banimento habitado por maus espíritos ${ }^{91}$. Ainda a respeito dos espaços do Skogskyrkogården, Asplund e Lewerentz o configuraram por meio da criação de percursos que marcam momentos de sensações variadas no local, como meditação, imersão, lembrança e revelação. Dessa forma, a caminhada neste cemitério foi pensada para funcionar como uma espécie de peregrinação, o que tornou o local símbolo de uma estética imersiva onde uma representação indomável da natureza procurou estabelecer correspondências entre o interior da floresta e o eu interior. Assim, o Skogskyrkogården se tornou uma referência para outros cemitérios das culturas do norte da Europa. ${ }^{92}$

Em relação ao seus arranjos e composições, não há dúvida de que Asplund e Lewerentz estavam atentos aos movimentos estéticos e sociais do começo do século XX, sendo profundamente influenciados por eles. Andersson (1998) acredita que parte do êxito do cemitério se deve justamente à adoção de um aspecto central do princípio do modernismo: criar espaços fluidos e transições claras. Nesse sentido, os arquitetos souberam associar aspectos do modernismo sem sobrepor-se a questões vernaculares, o que não era comum ao movimento como um todo. Esse talvez seja o grande exemplo que o Skogskyrkogården oferece ao período. Em um momento em que estilos históricos de arquitetura estavam sendo submetidos às demandas racionais e totalizantes do modernismo, ele conseguiu mostrar que era possível estar em contato com as raízes culturais de uma região sem precisar se submeter a linguagens absolutas.

91

Cf. Landscapes of Fear: Perceptions of Nature and the City in the Middle Ages. Vito Fumagalli, 1994.

92

Outros cemitérios paisagísticos europeus, são os Cemitério Mariebjerg, em Copenhague (1925-36), Cemitério Geral de Wim Boer, em Doorn na Holanda (1952-8), Cemitério Almere-Haven de Christian Zalm, também na Holanda (1975). 
Assim, o Skogskyrkogården transcendeu seu tempo de uma forma que poucas obras foram capazes. Nesse sentido, por mais que tenha sido estabelecido há aproximadamente um século, o conceito do cemitério floresta parece pouco explorado em contextos para além do norte da Europa, podendo ser entendido ainda como uma perspectiva a ser discutida. O retorno à natureza do Skogskyrkogården caminha num sentido menos idílico que o dos cemitérios verdes modernos. Neste aspecto, ressalta-se, a floresta não deve ser entendida como vegetação nativa, mas como uma área verde extensa com cobertura arbórea relativamente densa. Ainda, a associação dos espaços desse cemitério aos monumentos fúnebres mostra uma preocupação não apenas com a evocação da imagem da floresta, mas também com a representação da morte.

Ampliando a discussão sobre a relação entre espaços de representação fúnebre, Worpole (2003) defende que há uma tensão constante entre a construção de monumentos e outras formas de memorialização, como a conexões afetivas à paisagem ou a disseminação de histórias. Assim, o autor atenta para os riscos de uma dependência excessiva na monumentalização como fonte de memória exclusiva, alertando que ela pode dar uma falsa sensação de permanência e continuidade. Worpole observa que à medida que são usados monumentos para fazerem o trabalho de memória, as pessoas tendem a não se preocupar e, de modo paradoxal, a esquecer mais facilmente. $\mathrm{O}$ autor associa esse argumento à crescente preferência pelo enterro natural em lugares como o Reino Unido ${ }^{93}$ e o norte da Europa, que rejeitam a monumentalização como forma de se relacionar com a morte.

O enterro natural é um procedimento que tem como ideia principal retornar o corpo à terra da maneira mais orgânica possível.

De acordo com o Natural Death Centre, existem mais de 270 sítios de enterro natural no Reino

Unido. Disponível em <www.naturaldeath.org.uk $>$ Acesso em: 21 jan.

2019. Ele costuma ser caracterizado pela rejeição de processos artificiais como a cremação e o embalsamento, além de se contrapor ao uso de invólucros como urnas e caixões. Decorrente principalmente do crescimento de uma maior consciência ecológica nas últimas décadas, o enterro natural tem a predileção pelo uso de recipientes biodegradáveis, colocando-se também de modo contrário à realização de procedimentos de tanatopraxia. No enterro natural, o corpo é encaminhado a terrenos de enterro naturais (natural burial grounds), normalmente áreas com grande presença de vegetação, especificamente protegidas para esse fim. 
Por sua vez, os terrenos de enterro natural, partindo de princípios da ecologia, buscam estabelecer um movimento cíclico em relação à vida. Entre as principais premissas desses locais estão, tanto enterrar os mortos como incentivar qualquer forma de vida, animal ou vegetal. Assim, o ser humano não é visto como entidade soberana neste cenário. Embora os terrenos de enterro natural tenham um aspecto que se assemelha a uma floresta nativa, eles costumam ser objeto tanto de organização paisagística como arquitetônica, devendo então ser entendidos como espaços planejados. Em muitos deles, as sinalizações usadas costumam ser pensadas de forma a serem absorvidas pela mata circundante. Desse modo, não é o local da sepultura que funciona como ponto focal da relação com o morto, mas é a própria totalidade da floresta que toma para si a relação material com a morte. Essa percepção é reforçada ainda pelo intuito de transformar os terrenos de enterro natural em reservas de preservação ambiental ao longo do tempo. Esse movimento é financiado pelos adeptos ao enterro natural e garantido pelas entidades responsáveis pelos terrenos de enterro natural que preveem, após os períodos de arrendamento, a sua conversão em uma área de proteção ambiental.

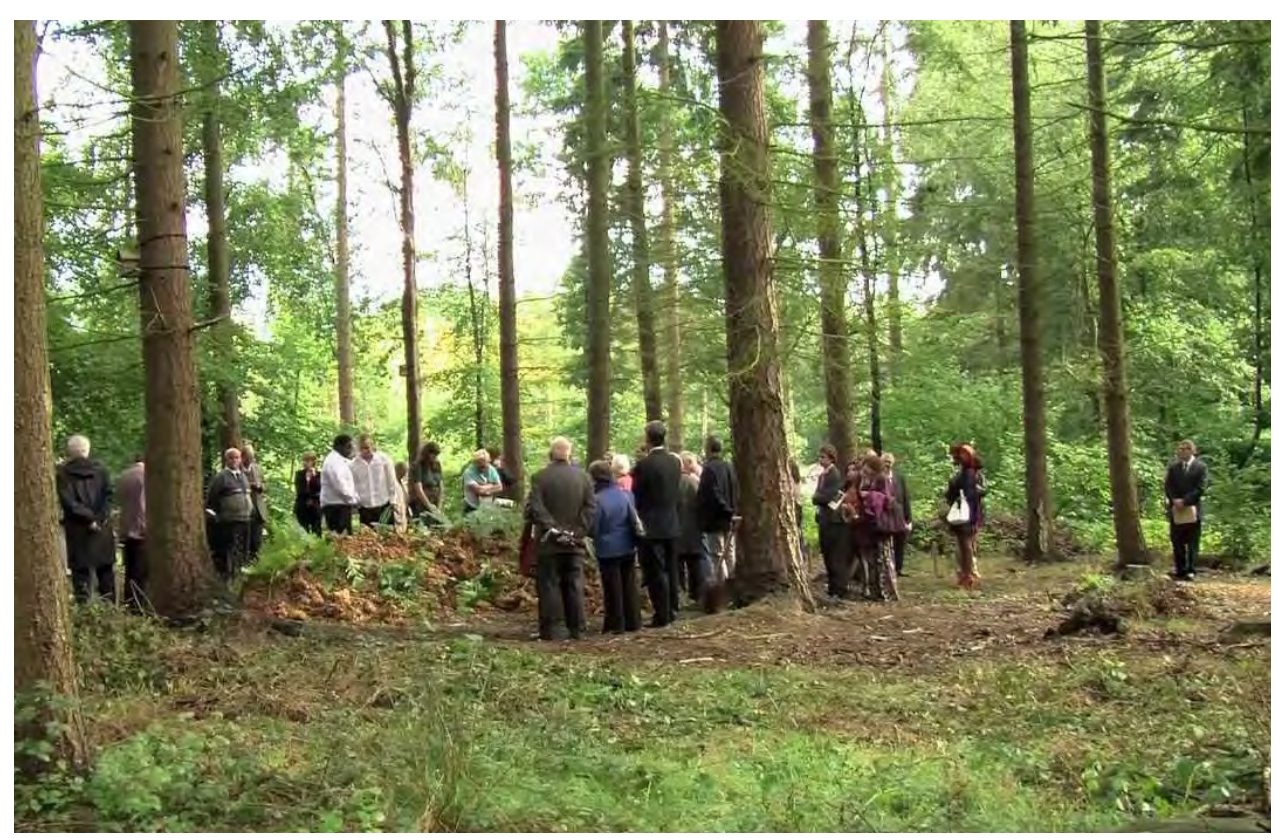

Img.32 Terreno de Enterro Natural (GreenAcres Woodland Burials) 
Assim, nesses lugares, o retorno à natureza deve ser entendido de forma distinta tanto da lógica dos cemitérios verdes modernos, como do sentido do cemitério floresta. Neste caso, os atributos estéticos-simbólicos são colocados em segundo plano e o retorno à natureza é pensado de forma orgânica, como meio de reduzir a pegada ecológica dos espaços funerários ao máximo. Worpole (2003) reforça esse entendimento ao afirmar que o enterro natural não é apenas um gesto antimonumental, mas também refuta uma longa tradição pela qual os lugares dos mortos são objetos de arranjos visivelmente manipulados. Essa abordagem reflete um distanciamento em relação aos sistemas do cemitério tradicional que refletem aspectos associados à família, classe social ou confissão religiosa. Assim, o enterro natural se coloca em oposição às práticas mais comumente adotadas nos últimos séculos, onde uma das principais funções dos enterros e da memorialização da morte foi deixar registros para a posteridade. Nos terrenos de enterro natural a morte é mimetizada ao ambiente, tornando-o semelhante a uma área de vegetação e de preservação ambiental. Essa condição pode ser vista então sob uma ótica de silenciamento da morte, assim como é feito em alguns cemitérios-jardim. No entanto, é preciso diferenciar o que pode ser entendido como o silenciamento da morte entre esses lugares. Para o enterro natural o ocultamento da morte funciona muito mais como uma consequência do que como um objetivo. Neste caso, a morte não é vista como um tema a ser evitado, mas é entendida numa perspectiva de transição do corpo para a natureza, do social para o natural.

Desse modo, a ausência de sinais decorrente do enterro natural é um fenômeno surpreendentemente contemporâneo, tendo como origem uma abordagem ecológica onde as questões ambientais sobrepõem-se a outros aspectos. Nesse sentido, ressalta-se novamente que os processos contemporâneos de lidar com a morte acabam por apresentar grande complexidade, sendo preciso assumir que trazem questões paradoxais, e, portanto, de difícil interpretação. Tendo em mente o estabelecimento de práticas como o enterro natural, é essencial refletir sobre como é possível relacionar a ideia de conscientização ecológica e preservação ambiental com a instauração de espaços para a morte onde a própria morte pode ser reconhecida. Para tal, encontrar um equilíbrio entre estas perspectivas e as formas de retenção de memória mais resilientes representa um verdadeiro dilema para as sociedades e culturas contemporâneas. 


\section{Cemitérios edificados}

O problema da falta de espaços nos cemitérios, além de ser um dos impulsores de processos como a cremação, também se tornou um dos principais motivadores pela busca por formas mais eficientes de ocupação de áreas. De modo a encontrar alternativas para a crescente demanda por áreas de sepultamento, algumas propostas de otimização de espaço começaram a surgir. Um exemplo é a construção de sepulturas conjuntas dentro de um mesmo recinto, bastante comuns em cemitérios particulares, os chamados de jazigos familiares. Outra solução foi o sepultamento acima do solo, em um arranjo composto por diversas gavetas em nichos, de modo similar aos ossários e columbários. Uma terceira e mais categórica opção foi o sepultamento em um edifício projetado especificamente para esse fim, conhecido como cemitério vertical, mas que será chamado de cemitério edificado no intuito de reforçar o aspecto construído mais do que a altura da estrutura em questão. Utilizados principalmente em locais densamente povoados e com falta de espaços de sepultamento, os cemitérios edificados também têm sido utilizados como alternativas para atender às religiões que proíbem ou desincentivam a cremação. Basicamente, são prédios que abrigam cadáveres em lóculos individuais, normalmente dotados de um sistema de tubulação para a saída de gases provenientes do processo de decomposição.

Considerado uma tendência mundial frente a explosão populacional em centros urbanos, o cemitério edificado é visto de modo favorável, entre outros, devido a fatores como a não poluição do meio ambiente, a vantagem de se poder realizar funerais em dias de clima desfavorável e em virtude do melhor controle de acesso e de segurança ao local. Para seus defensores, ele é um marco da modernização dos sepultamentos, sendo uma solução bastante eficaz para os problemas de sepultamento nas cidades. Em entrevista veiculada pela Associated Press ${ }^{94}$, Tuvia Sagiv, arquiteto especializado no projeto desses edifícios, defende a expansão dessa solução pois acredita que "é irracional que vivamos uns sobre os outros em edifícios altos de apartamentos mas queiramos morrer em casas de campo. Se já aceitamos viver uns sobre os outros, então também podemos morrer uns sobre os outros".

94

Entrevista concedida a Aron Heller (2014): Israel inova com construção de cemitérios verticais. Disponível em <www1.folha.uol.com.br/mundo/2014/10/1538979-israel-inova-com-construcao-de-cemiterios-verticais.shtml> Acesso em: 4 jan. 2019. 
Soluções de cemitérios edificados foram desenvolvidas de diferentes formas e em variados lugares, apresentando, assim, uma gama de construções arquitetônicas. Alguns desses exemplos podem ser encontrados em cidades como Tel Aviv (Yarkon Cemetery) e Tóquio (Shinjuku Rurikoin Byakurengedo). No Brasil, a cidade de Santos também possui o seu cemitério edificado, o Memorial Necrópole Ecumênica que com seus 32 pavimentos detém o título de mais alto do mundo até o momento (fevereiro de 2019). Ainda no estado de São Paulo há outros cemitérios edificados, como o Phoenix Memorial do ABC, em Santo André, o Memorial do Alto Tietê, em Suzano e o Memorial Guarulhos. Outros projetos e planos para cemitérios edificados têm surgido e ganhado espaço em outras cidades como Oslo (The Vertical Graveyards), Paris (Vertical Cemetery for Paris), Mumbai (Moksha Tower) e na Cidade do México (Torre de los Muertos).
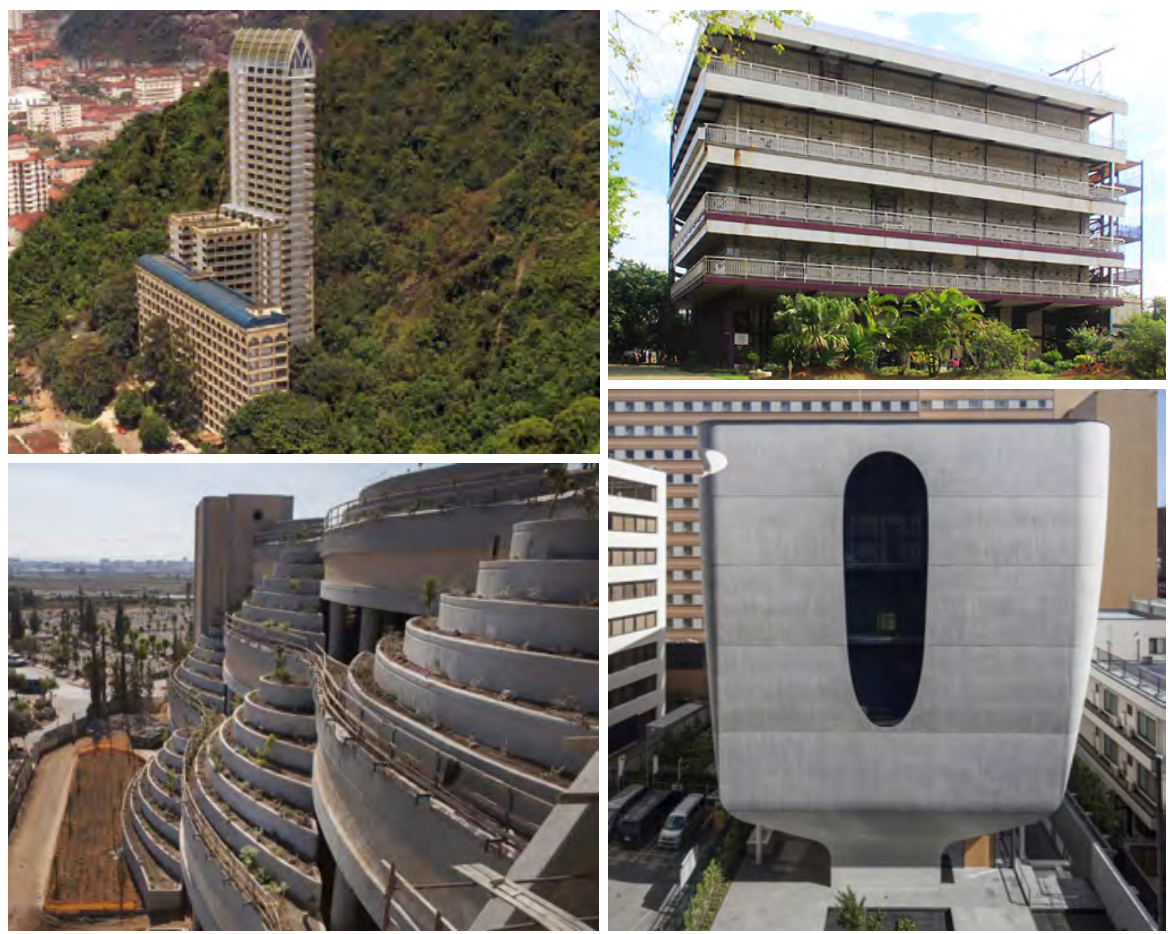

Img.33 Memorial Nécropole Ecumênica

Img.35 Phoenix Memorial em Santos (melhordesantos.com)

em Santo André (phoenixmemorial.com)

Img.34 Cemitério Yarkon em Tel Aviv (haaretz.com)

Img.36 Shinjuku Rurikoin Byakurengedo em Tóquio (hiddenarchitecture.net) 
A solução de verticalizar sepulturas em um edifício tem ganhado lugar em centros urbanos, sendo amparada principalmente por planejadores urbanos e arquitetos que encontram nesta solução uma saída para os problemas de falta de espaço. Ainda, usa-se a seu favor o argumento do seu desempenho ambiental, pois ele deixa os solos e águas subterrâneas sem risco de contaminação. No entanto, é preciso atentar para que essa retórica não se sobreponha à presença dos cemitérios ao ar livre (por assim dizer), de modo a enfraquecer sua importância. Nota-se que boa parte do discurso a favor do cemitério edificado vertical não se volta à melhoria dos cemitérios existentes, mas à construção de novos cemitérios que se assemelham mais a um empreendimento do que a um espaço fúnebre.

Somado a esse fator, ressalta-se a importância de encontrar soluções capazes de incorporar não apenas aspectos pragmáticos, mas que também sejam capazes de comportar toda a carga simbólica presente na temática da morte. Até o momento, grande parte das soluções apresentadas fundamentam-se em aspectos predominantemente técnico-científicos, não desenvolvendo concepções que evidenciam os assuntos ligados aos processos de memória, religiosidade e de luto. É fundamental ampliar a abordagem de modo a considerar a riqueza interdisciplinar que o tema demanda. Apenas assim a solução de edificação fúnebre poderá ser pensada de forma a conciliar os aspectos técnicos e espaciais com as dimensões afetivas e simbólicas, de modo a encontrar meios de elaborar símbolos e ritos que contemplem a morte e os mortos.

Como experiência de cemitério edificado que busca desenvolver essas questões, é possível apontar o projeto do Cemitério San Cataldo pensado pelos arquitetos Aldo Rossi e Gianni Braghieri em Modena, na Itália. Concebido a partir de um concurso para a expansão de um complexo funerário existente desde 1876, a construção do San Cataldo começou em 1976, sendo que até os dias atuais (fevereiro de 2019) não foi finalizada conforme o projeto. Construído na gênese do movimento pós-modernista, ele é apontado como obra-chave do trabalho de Aldo Rossi. Na prática, o local ficou mais conhecido como peça arquitetônica do que como cemitério, tendo gerado tanto admiração como controvérsia desde sua criação. No entanto, para além das discussões relativas à história da arquitetura, o San Cataldo apresenta aspectos significativos que podem servir para se refletir sobre o que pode ser chamado de "arquitetura para os mortos", no sentido de pensar a construção de um edifício fúnebre. 
O cemitério consiste de uma série de prédios que contêm salas onde estão locados milhares de nichos para colocação dos restos mortais. Em termos de composição, ele é estruturado por um bloco retangular de três andares que abraça um volume cúbico de quatro níveis, este marcado por pequenas aberturas quadradas. Junto a este cubo, também na parte central, foi prevista de uma estrutura composta por linhas que mudam de tamanho para formar o desenho de uma pirâmide, mas que não foi construída. O próprio Aldo Rossi, em sua Autobiografia cientifica, escreve (2013, p.67): “o conceito central deste projecto era talvez o de ter visto que as coisas, os objectos, as construções dos mortos não são diferentes das dos vivos". Desse modo, tendo como paralelo a cidade dos vivos, o Cemitério San Cataldo pode ser entendido como um complexo habitacional para os mortos. Assim como os conjuntos residenciais que ganharam espaço durante o século XX, o projeto do cemitério procurou trabalhar as relações tipológicas de moradia para os mortos. Para tal, Rossi buscou estabelecer analogias às ideias de túmulo, casa, à cidade e cemitério (HAYS, 2010).
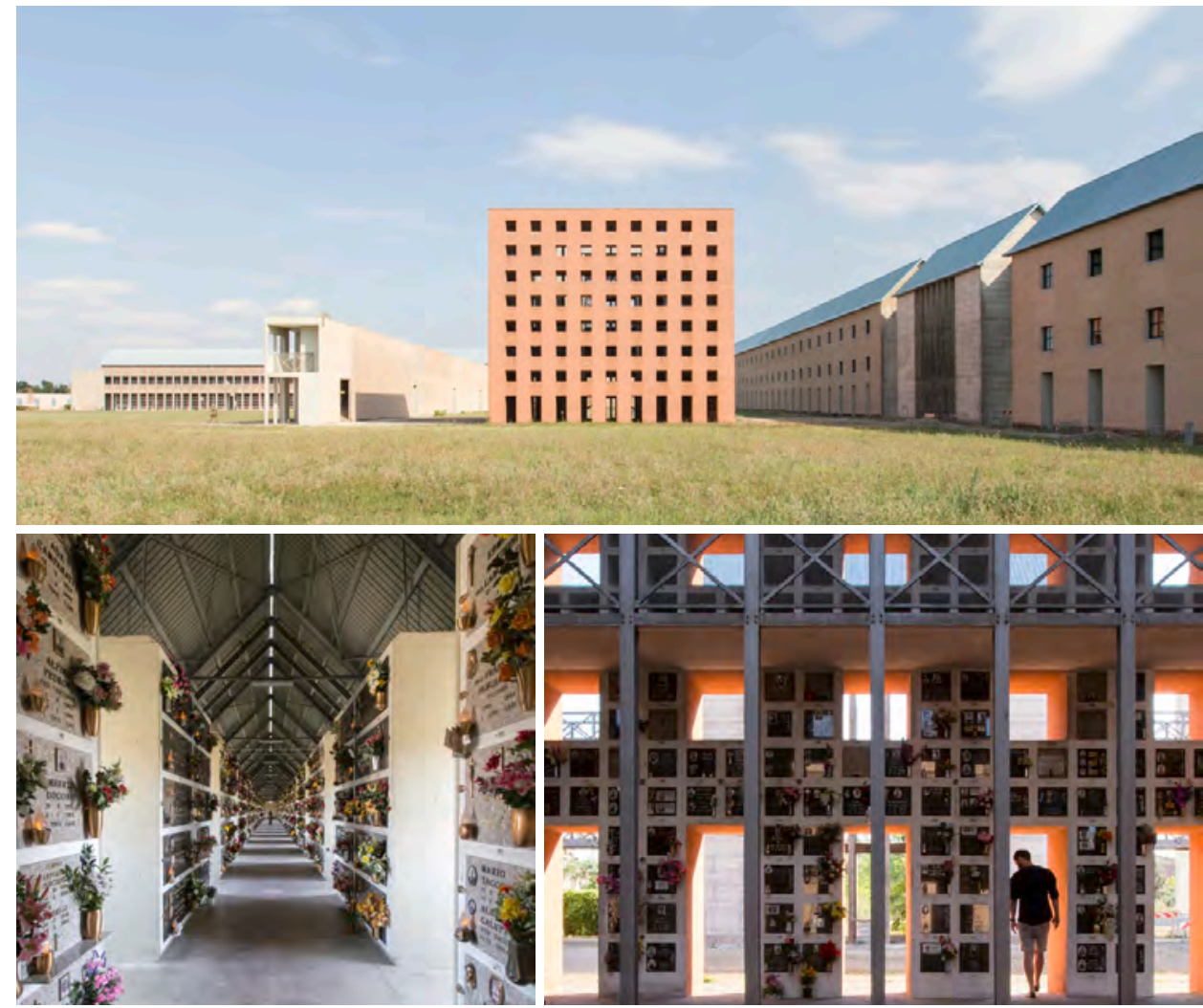

Img.37 a 39 Cemitério San Cataldo (archdaily.com) 
Ao mesmo tempo trabalhou as questões construtivas, o arquiteto procurou estabelecer a transposição dos aspectos funerários do local. Connelly (2017) demonstra que Rossi se esforçou em criar um cemitério que abordasse tanto as transformações das atitudes sociais e culturais em relação à morte de sua época, como as tradições e símbolos funerários históricos. Familiarizado com os costumes italianos, o arquiteto se esforçou em deixar o cemitério aberto a manifestações e reflexões pessoais, imaginando um lugar que fosse capaz de oferecer consolo através de uma experiência arquitetônica sensível aos simbolismos da transcendência entre vida e morte.

Para tal, os componentes do conjunto carregam uma série de simbolismos que buscam se conectar aos aspectos físicos e metafísicos entre a vida e a morte. A ideia de abrigo e acolhimento, por exemplo, está presente em elementos como a cobertura em duas águas presente que remetem à imagem primária de uma casa italiana vernacular. Ainda, outros aspectos que podem ser destacados são as escolhas de materiais ásperos e de aparência inacabada, feitos de forma a mostrar os sinais das intempéries e da passagem do tempo, evidenciando, assim, seu envelhecimento ao longo dos anos (CONNELLY, 2017). Desse modo, mesmo sendo um projeto que é principalmente associado a um movimento estético passado, San Cataldo pode ser visto como um exemplo de arquitetura edificada fúnebre que busca encontrar relações atreladas tanto a aspectos técnicos, como sensíveis, podem contribuir na reflexão de projetos de cemitérios edificados.

Ressalta-se que é importante pensar na utilidade da edificação e da verticalização de ocupações e usos nas grandes cidades. No entanto, esse movimento não deve ser resumido a um ímpeto de empilhamento de lóculos ou nichos para otimização do espaço. Como qualquer aspecto relativo à questão fúnebre, ele deve ser visto também do ponto de vista afetivo e simbólico. Nesse sentido, a correspondência sugerida por Rossi entre os objetos dos vivos e dos mortos pode ser entendida não como um gesto literal, mas como um reconhecimento da importância de se pensar os espaços para os mortos com a mesma dedicação que se pensa os espaços dos vivos. 


\section{Projeto, paisagem, percurso, processo}

Se por grande parte do século XX os arquitetos e paisagistas pouco se dedicaram a pensar sobre os espaços fúnebres, no final deste período e durante o começo do século XXI esse cenário começou a mudar. A partir do final dos anos 1980, foram elaborados cemitérios projetados por arquitetos e paisagistas contemporâneos, apresentando novos indícios de como esses locais poderiam ser configurados ou reconfigurados. Introduziu-se projetos de cemitério baseados em uma leitura do contexto do lugar e da sociedade em que estão inseridos. A partir de uma pequena seleção de algumas dessas propostas percebe-se que é possível encontrar meios para se pensar a questão fúnebre tendo em vista tanto os processos históricos e sociais, como uma perspectiva conjuntural corrente.

O maior símbolo deste tipo de espaço fúnebre é, possivelmente, o Cemitério de Igualada, situado nos subúrbios de Barcelona. Construído a partir de um concurso ganhado por Enric Miralles e Carme Pinós, ele foi inaugurado em 1994. O projeto foi pensado de modo a se integrar com as colinas da Catalunha, buscando uma fusão entre arquitetura e paisagem como elementos em consonância. Para tal, os arquitetos usaram paredes de

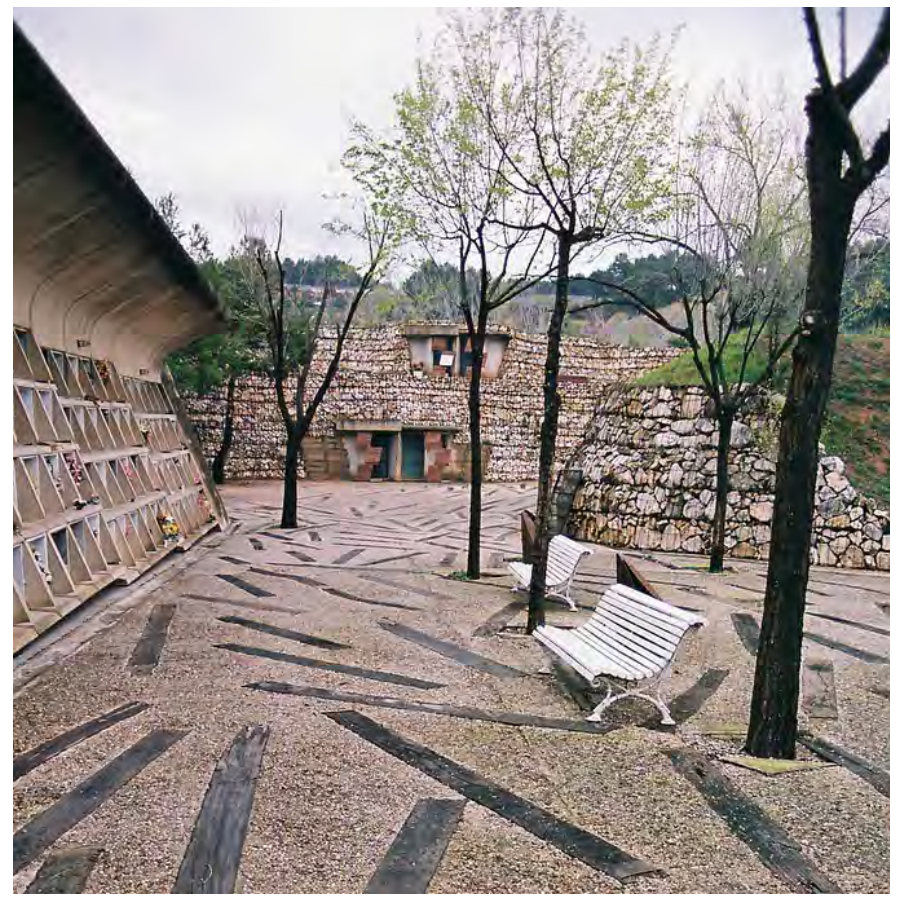

Img.40 Cemitério de Igualada (arquisópio.com) gabião como contenção dos arrimos, trabalhando a topografia de forma a conduzir os visitantes aos espaços de abrigo dos corpos. Nas palavras do próprio Miralles: “quando não se pretende adotar a tabula rasa, impondo um projeto a um lugar, não resta nada além de desenvolver uma sensibilidade para a realidade, assim a arquitetura não tem outra solução que o respeito ao lugar e ao programa" ${ }^{\prime 95}$.

95 Conforme <www.grcstudio.es/ portfolio/p-l-o-t-_-11-parque-delcementerio-de-igualada-miralles-pinos $>$ Tradução nossa. Acesso em: 20 jan. 2019. 
Observa-se que, além da leitura do lugar, os arquitetos buscaram compreender as necessidades e os costumes dos frequentadores locais. Com isso, chegaram a um resultado sensível e cuidadoso, tendo desenvolvido diversos aspectos relativos à ambiência do local, como o desenho de mobiliários urbanos. Nesse sentido, nota-se o cuidado dos arquitetos com os detalhes, como a preocupação com a forma das estruturas de nichos, que tem seu desenho de cobertura pensado de modo a proteger os corpos das intempéries.

Outro espaço de cemitério que busca uma conexão com a paisagem, porém de uma forma distinta da proposta por Miralles e Pinós, é o Cemitério Finisterre, de César Portela. Localizado na chamada Costa da Morte, na Galícia, o local é um promontório que se estende em direção ao oceano Atlântico, assim chamado por causa dos muitos navios que naufragaram na região. O Finisterre é um pequeno cemitério, composto por uma série de cubos de granito que contêm os nichos para os corpos, dispostos de forma desalinhada e com vista para o mar. Além dos cubos, há três outros edifícios no mesmo estilo: uma capela, um necrotério e um laboratório forense. A conexão do Finisterre com a paisagem, para Portela, é feita através de uma relação simbólica. O arquiteto conta que procurou oferecer "um espetáculo voltado para os mortos e os deuses, situado neste lugar mágico", de modo a afirmar "a arquitetura como espaço sagrado na relação com o mundo" (apud WORPOLE, p.189, tradução nossa). Através dos volumes espalhados pelo território, o cemitério tem a intenção de se colocar como um elo entre o mar, a montanha e o céu. Desse modo, o fundamento do cemitério é dado por meio das ressonâncias emotivas despertadas pela paisagem do lugar, onde a associação entre arquitetura e natureza busca se estabelecer como um símbolo de devoção.

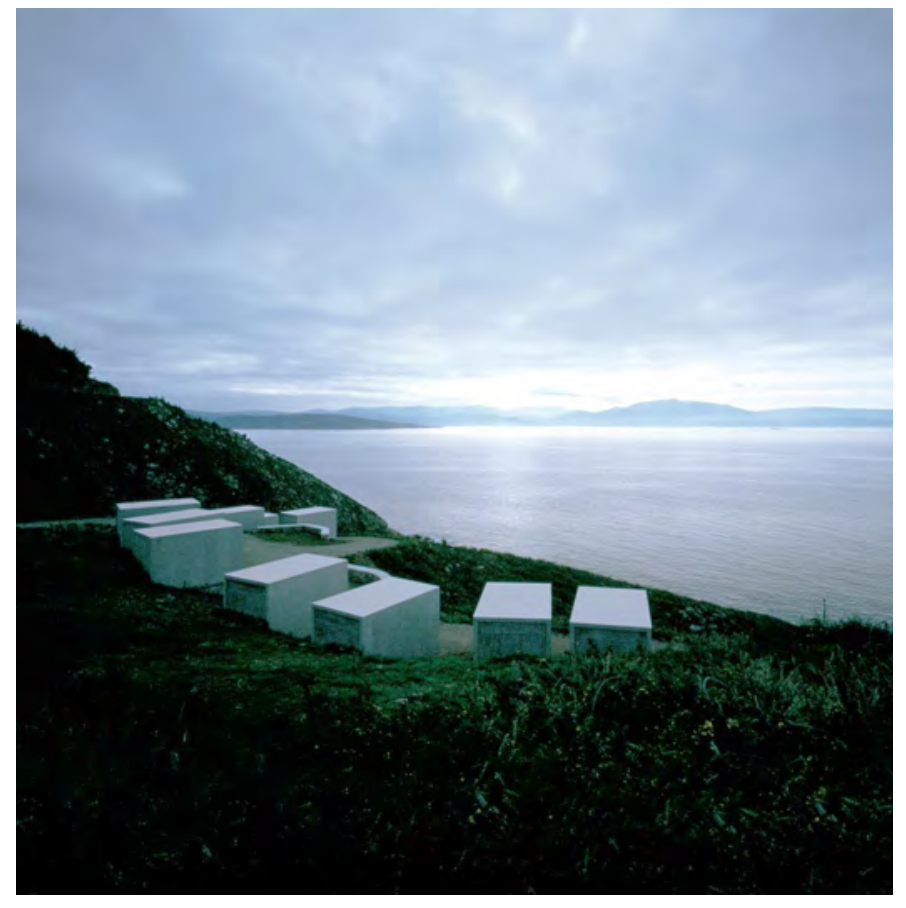

Img.41 Cemitério Finistierre (cesarportela.com) 
A relação com a paisagem também é um ponto central do cemitério elaborado pelos arquitetos Bernardo Secchi e Paola Viganò para a cidade de Courtrai (Kortrijk), na região de Flandres, Bélgica. Neste caso, Secchi conta que partiu da premissa de repensar a condição esperada de estabelecer o cemitério como um recinto compacto e cercado por muros que delimitam um interior e um exterior. Com isso em mente, os arquitetos conceberam o espaço a partir do conceito de percurso, favorecendo a ideia de apreciação da paisagem. Ao longo do curso, o ambiente leva os transeuntes a meditarem sobre a paisagem não apenas do cemitério em si, mas da região de Flandres, oferecendo amplas vistas que acompanham o trajeto $^{96}$. Buscando dar continuidade às visuais, o edifício do crematório, projetado pelo arquiteto Eduardo Souto de Moura, foi pensado como um volume semi-enterrado, de forma a se acomodar no aclive do terreno. Desse modo, percebe-se que os arquitetos envolvidos no projeto do cemitério de Courtrai procuraram valorizar aspectos tocantes ao lugar, estabelecendo uma associação sensível entre seus atributos e a configuração do cemitério.

96 Conforme palestra proferida por Bernardo Secchi em colóquio organizado pelo SIFUREP (Syndicat Intercommunal Funéraire de la Région Parisienne), em 19 de outubro de 2010 (THIOLLIERE, 2016, p.335-338).

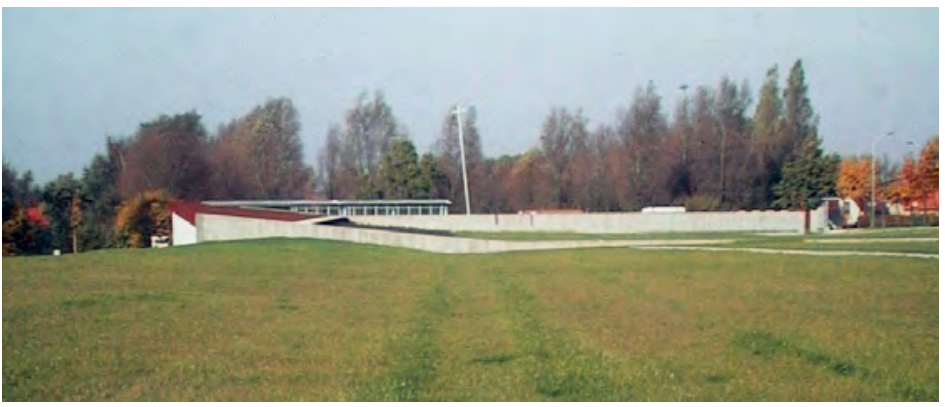

Img.42 a 43

Cemitério de Courtrai (miesarch.com)

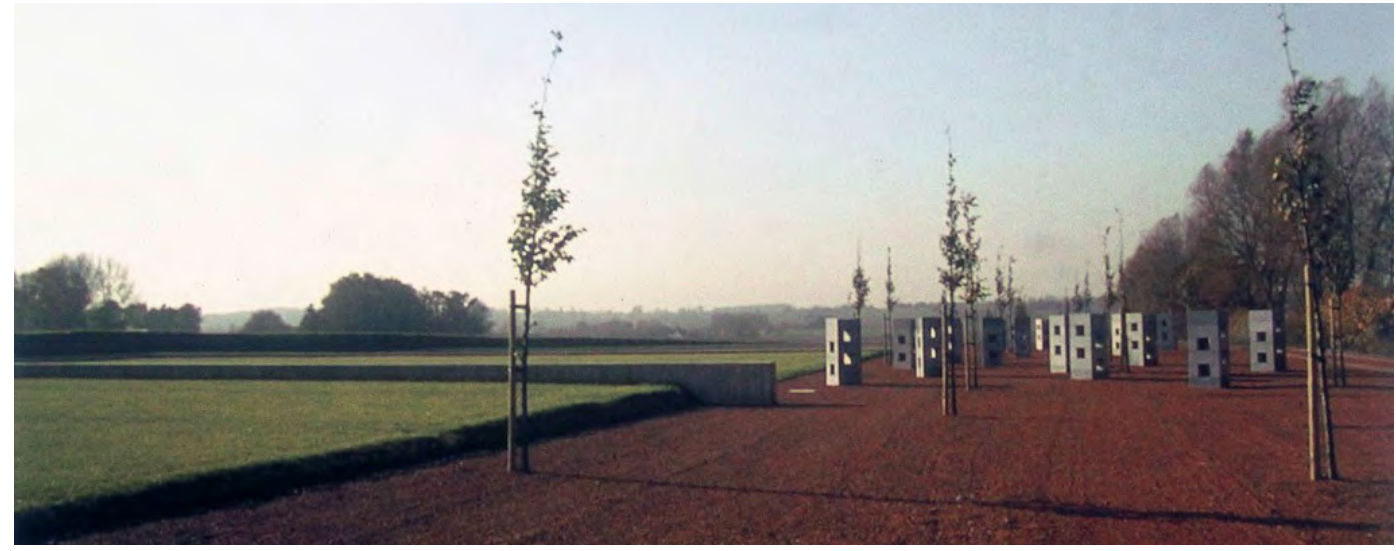


Um outro projeto que chama atenção é o do Cemitério Beausoleil projetado pelo arquiteto Philippe Madec em Sorinières, numa pequena área montanhosa rural da França. O espaço foi concebido de forma a criar ambientes específicos para os diversos meios de tratamento do corpo falecido. O cemitério oferece locais pensados para uma variedade de formas de destinação do corpo: enterro, colocação em nichos, estrutura de ossários e jardim de recordações para espargimento das cinzas (CAUE44, 2011). Cada ambiente foi pensado para configurar um cenário de meditação distinto, favorecendo a criação de espaços íntimos. Desse modo, percebe-se a preocupação do arquiteto em pensar o cemitério levando em conta tanto costumes enraizados como a pluralização de práticas contemporâneas.

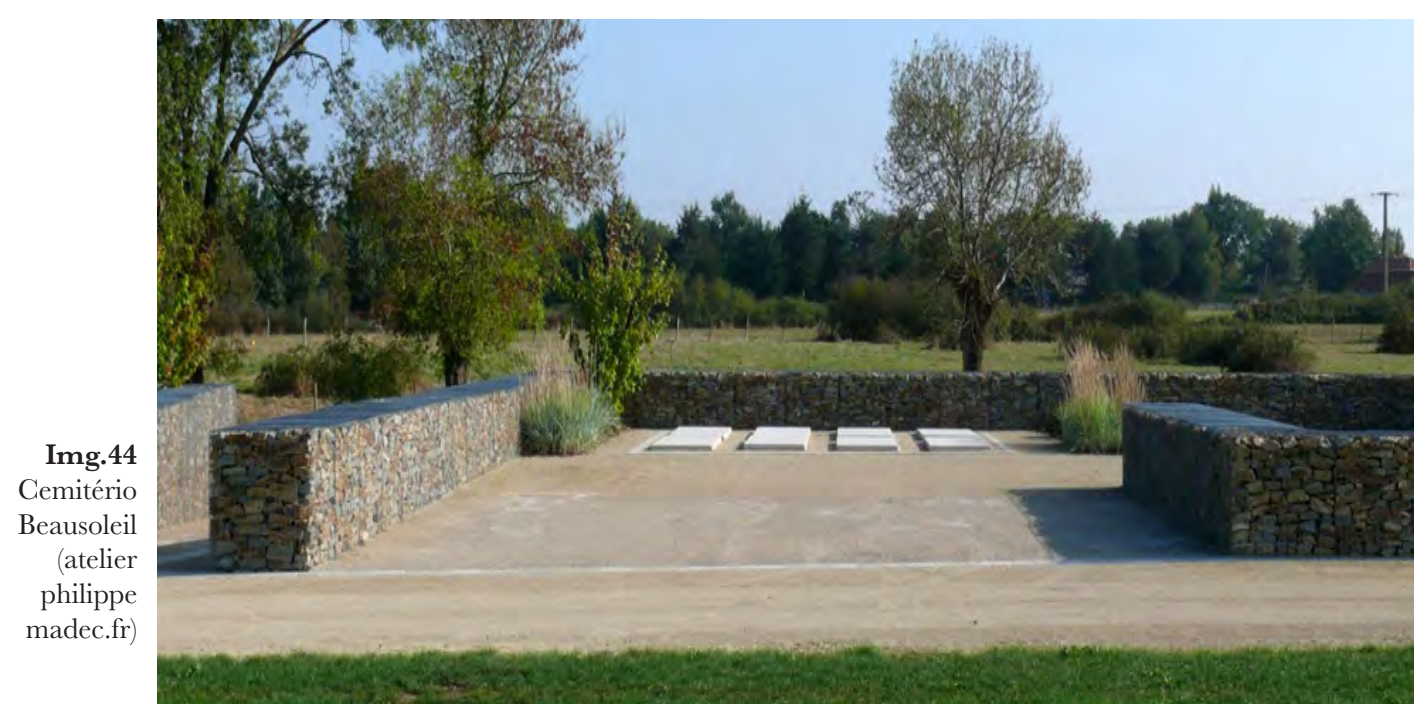

Por fim, um último exemplo de espaço projetado com base em leituras regionais é o Cemitério Valle Armea, em Sanremo, Itália. Projetado por Ivano Amoretti e Marco Calvi, este local, assim como o Beausoleil, busca oferecer diferentes opções em relação à destinação do corpo, o que é percebido através da configuração do cemitério. O Valle Armea é composto por uma área de sepultamento, uma torre de ossários individuais e um ambiente de cinerário comum. A área de sepultamento está distribuída em patamares que seguem a morfologia acentuada do terreno, formando espécies de terraços que se direcionam à percepção da paisagem local. No ponto focal desse espaço, está a torre de ossários, que serve com um marco de referência vertical e representa uma parte edificada do cemitério. Já o espaço cinerário fica em um claustro, buscando criar uma atmosfera 
mais intimista. A lógica do cemitério tem como base uma escala gradual de transformação do corpo morto. Primeiramente, os corpos são sepultados. Depois, após um período de 40 anos, os restos são transferidos ou para a torre em urnas individuais ou para uma área memorial de dispersão das cinzas (C3 MAGAZINE, 2008). O cemitério apresenta uma configuração que busca, ao mesmo tempo, evitar a saturação dos espaços e respeitar o tempo dos processos de luto e memória. Desse modo, ao oferecer uma passagem gradual do individual ao coletivo, o Villa Armea permite expressar as singularidades sem necessidade de estabelecer monumentos de proeminência individual.

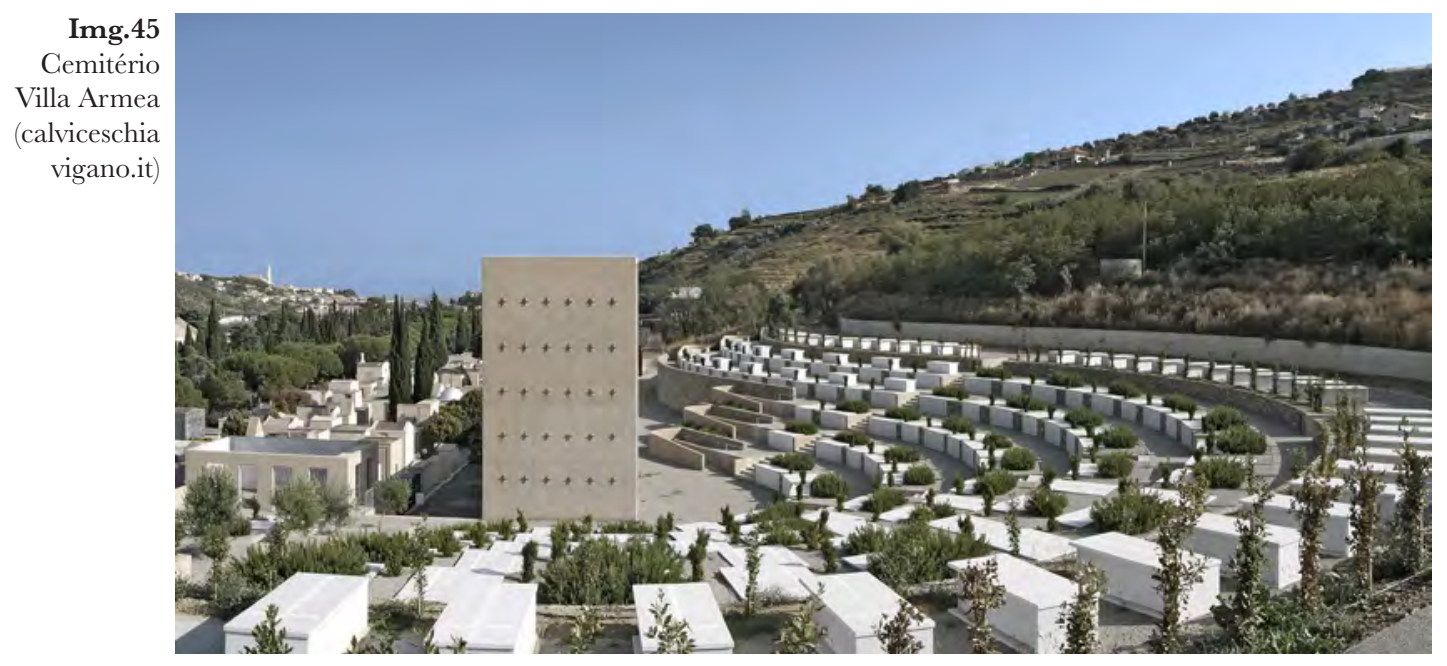

Considerando os projetos vistos brevemente neste tópico, é possível vislumbrar a espacialização e materialização de alguns dos pontos discutidos nesta dissertação. Outras propostas também poderiam ser trazidas, no entanto, entende-se que com estes exemplos já é possível elucidar algumas formas de se responder à problemática do espaço a partir do seu contexto local e social. A partir deles, percebe-se um movimento em direção à busca de um diálogo com aspectos tanto da paisagem e do entorno, como das práticas e convicções variadas. A seu modo, cada um deles apresenta concepções de projeto, paisagem, percurso e processo, oferecendo espaços dinâmicos e conexos com as variáveis encontradas. Dessa forma, através de suas características e aspectos peculiares, pode-se dizer que eles representam um movimento de conciliação entre a problemática da morte e as formas de se pensar o espaço e a cidade contemporânea. 


\section{$\underline{\text { Tecnologias e os espaços fúnebres }}$}

O desenvolvimento de novos procedimentos para destinação dos cadáveres tem aparecido como ferramenta de transformação das práticas fúnebres. Tendo como origem os avanços tecnológicos, a maior parte deles apresenta soluções aos aspectos técnicos de tratamento do corpo, mas não explora sua relação com o lugar, sendo necessário uma maior aproximação e experimentação junto aos espaços fúnebres.

Com isso em mente, a arquiteta e professora Karla Rothstein criou, em 2013, o DeathLAB, um laboratório de pesquisa na Universidade de Columbia que tem como objetivo encontrar soluções para a questão da morte nas grandes cidades contemporâneas. O DeathLAB se propõe a discutir a mortalidade humana e os vestígios dos mortos de modo a aliar as novas tecnologias de metamorfose do corpo à arquitetura e ao espaço urbano e social. Para tal, ele incentiva a realização de estudos, propostas e projetos que tratam da problemática dos espaços para a morte. Rothstein (2016) defende que a arquitetura e o design podem direcionar uma mudança sociocultural, incorporando novas práticas e provocando uma importante reflexão sobre a relação entre vida e morte. A arquiteta ressalta que as "novas práticas requerem espaços físicos que sustentem a espiritualidade social e individual, associada ao luto e à memória, como sistemas e processos avançados ambientalmente sustentáveis" (2016, p.115).

A partir dessas premissas, o DeathLAB elaborou projetos a partir de sistemas de decomposição orgânica baseados no que podem ser chamadas de células químicas memoriais. Estas células atuam de modo a processar os restos mortais por meio de metanogênese microbiana, empregando tecnologias onde a matéria corporal é transformada em energia. Esta, por sua vez, pode ser utilizada para gerar efeitos luminosos que chegam a ter duração de até $25 \operatorname{anos}^{97}$. A partir de diferentes combinações e aplicações dessas células, o DeathLAB apresentou três principais circunstâncias para sua utilização: áreas urbanas remanescentes, infraestruturas urbanas pré-existentes e espaços de cemitério saturados.

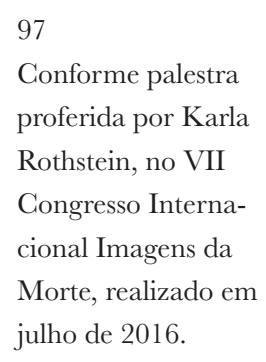
proferida por Karla Rothstein, no VII Congresso Internacional Imagens da Morte, realizado em julho de 2016. 
No primeiro caso, a proposta (WPA 2.0) foi feita de forma a oferecer utilidade $\mathrm{a}$ áreas urbanas não aproveitadas que poderiam ser convertidas em lugares dedicados à morte em meio à cidade. Esses locais seriam usados para a criação de estruturas verticais de acomodação das células químicas memoriais que, ao serem consideradas de modo conjunto, passariam a ser entendidas como uma manifestação memorial coletiva. Dessa forma, essas estruturas conseguiriam se diferenciar do que poderia ser considerado um cemitério edifício padrão, oferecendo espaços que funcionariam tanto como ponto de apoio ao luto e à memória, como ambientes integrantes da dinâmica cívica da cidade.

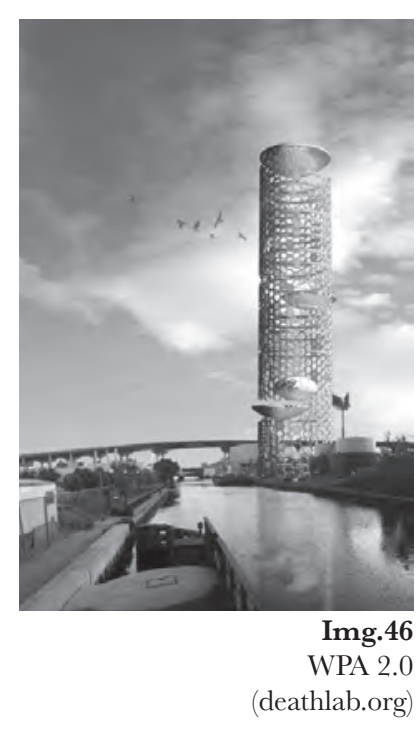

98 Ao discutir essa proposta com um conhecido, adepto da tradição baiana do "nego fugido", ele ressaltou que essa forma de relação é muito próxima ao que sua comunidade busca estabelecer, usando elementos do cotidiano para se expandir a relação com os antepassados.
A segunda proposta sugerida pelo DeathLAB foi apelidada de Parque das Constelações (Constellation Park). Neste caso, o sistema de células memoriais foi pensado de modo a se vincular a uma estrutura pré-existente, criando uma constelação de luzes no local. Com isso, os processos de luto e memória deixam de estar atrelados à espaços específicos e podem aderir a estruturas marcantes como a Ponte Manhattan, em Nova Iorque. Ao situar essas constelações em locais desse tipo, a proposta pretende expandir a capacidade de visualização do memorial luminoso, evidenciando-o no cerne do cotidiano urbano. Assim, suscitam-se reflexões importantes sobre as articulações possíveis entre morte e cidade, eliminando a separação normalmente existente entre ambos. Nesse sentido, essa concepção remete, de certa forma, à integração entre vida e morte existente no período medieval, onde os mortos estavam ambientados na dinâmica cotidiana. No entanto, se essa proposta é instigante do ponto de vista conceitual, ela ainda carece de maior desenvolvimento sobre seus aspectos práticos, pois costuma levantar mais questionamentos do que respostas sobre seu funcionamento e sobre sua aceitação frente a costumes mais tradicionais. Por outro lado, para algumas culturas que ensejam a aproximação entre vida e morte ${ }^{98}$, ela pode representar uma aproximação bastante profícua. 
Se as duas propostas apresentadas até aqui parecem distantes de uma realidade exequível, é possível que em um futuro próximo seja viabilizada uma outra proposta do DeathLAB, a de integrar as células memoriais a cemitério existentes. Em fevereiro de 2016, a chamada Sylvan Constellation foi anunciada como vencedora de uma competição

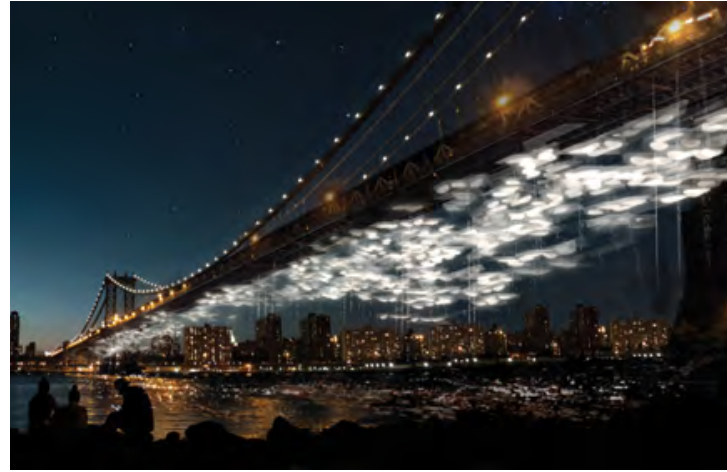

Img.47 Constellation Park (deathlab.org) idealizada pelo Cemitério Arnos Vale, na Inglaterra. A proposta consiste em uma constelação memorial de 150 células pensada de modo a iluminar uma área em meio à vegetação local, criando uma nova ambiência e ampliando a capacidade de uso do cemitério já saturado. Para tal, o projeto prevê a instalação de estruturas delgadas de aço que servem de apoio para sustentar as células. Neste caso, a tecnologia surge como recurso para expandir as formas de uso do espaço de cemitério, apresentando-se, do mesmo modo que a cremação, como solução para a falta de espaços.

Em comum, as três propostas trazem a ideia de usar células memoriais que funcionam como meio material e simbólico para representar tanto uma memória cintilante, como a passagem do tempo. Tendo em mente as discussões de representação da morte e do duplo, essas propostas suscitam reflexões que ainda precisam ser desenvolvidas. Como pode ser percebida a associação de vidas passadas com a ideia de luz? Como funcionaria a relação entre dia e noite, claro e escuro desses mecanismos? Ao associar o tempo a um evento prático como a duração da luz, o que representaria seu apagamento? Quando isso ocorresse, o

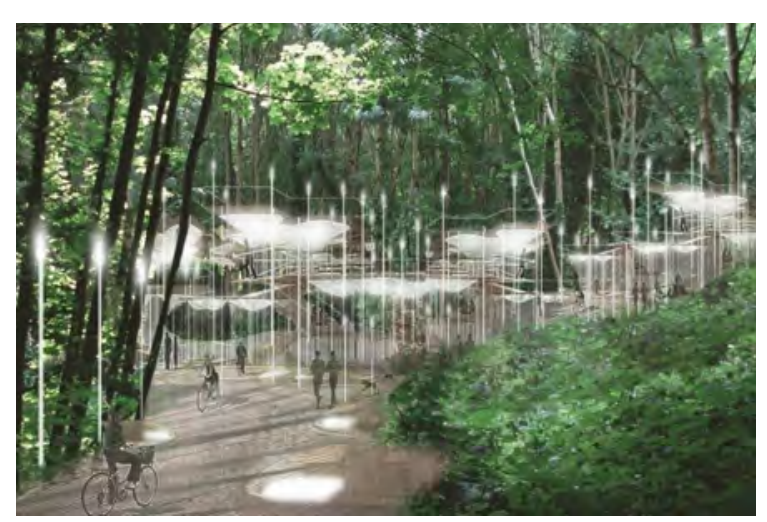

Img.48 Sylvan Constellation (deathlab.org) que aconteceria com as células? Enfim, diversas outras questões poderiam ser colocadas, no entanto, ressalta-se que o intuito ao levantar essas reflexões é apenas salientar a importância que deve ser dada à discussão dos significados e das relações que os novos dispositivos trazem nas formas de se relacionar com a morte e seus espaços. 
Além das proposições elaboradas pelo DeathLAB, também em outros contextos têm surgido iniciativas que buscam ampliar a abrangência dos espaços fúnebres através de soluções que unem aspectos da arquitetura, do design e da tecnologia. Outro exemplo é o concurso internacional para o projeto de um cemitério vertical em Tóquio, organizado pelo núcleo de pesquisa de arquitetura Arch Out Loud. Entre as 460 propostas apresentadas ${ }^{99}$, foi escolhida vencedora um projeto elaborado por uma equipe de arquitetos chineses intitulado $A$ morte 99 Cf. <www. archout loud.com /tok-results. html> Acesso em: 20 out. 2018. não é o fim, ser esquecido é (TOLJ 2017, p.112, tradução nossa).

Neste caso, os arquitetos imaginaram uma solução onde pequenas caixas com as cinzas são inseridas em balões de hélio revestidos com material oxidante. Por sua vez, os balões são dispostos no local de projeto, um espaço subterrâneo, sendo amarrados ao piso por cabos de fibra ótica e associados a uma manivela que funciona através de um sistema de contagem do tempo. Após a colocação das cinzas, o sistema ativa uma contagem regressiva que inicia um ritual de despedida ao mesmo tempo que acompanha a subida dos balões. $\mathrm{O}$ tempo de ascensão varia de acordo com a frequência das visitas. Quando amigos e familiares vão ao local, o movimento é suspenso, caso nenhum visitante venha, o balão segue subindo em direção ao céu. Eventualmente, o balão atinge uma altura onde o revestimento oxidante se incendia e as cinzas voltam ao piso em forma de poeira. Desse modo, observa-se que, nessa proposta, de forma semelhante às células químicas memoriais, a solução adotada passa por estabelecer dispositivos que funcionem de modo efêmero, indicando uma preocupação com a questão processual e temporal. Se no caso do DeathLAB a luz é usada de forma alusiva, neste caso é o balão que assume um papel simbólico, transformando a metáfora de ascensão aos céus pelos mortos em algo literal. Nesse sentido, se antes havia críticas a um processo entendido como a invisibilização da morte, neste caso ela não é ocultada, mas evaporada, confundindo a referência do espaço simbólico céu com o lugar físico atmosfera. Além dessa questão, é válido refletir também sobre a associação estabelecida entre a contagem literal do tempo de ascensão e a frequência de visitação. Nesse aspecto, parece inevitável pensar em uma percepção singela sobre a morte, associando-a a elementos próximos de uma esfera infantil, como o balão e a recompensa recebida por comportamentos adotados. Desse modo, nota-se que a proposta apresenta métodos pouco convencionais para se lidar com os processos temporais da morte, revelando uma perspectiva onde os aparatos são usados numa lógica muito mais teatral do que sensível. 


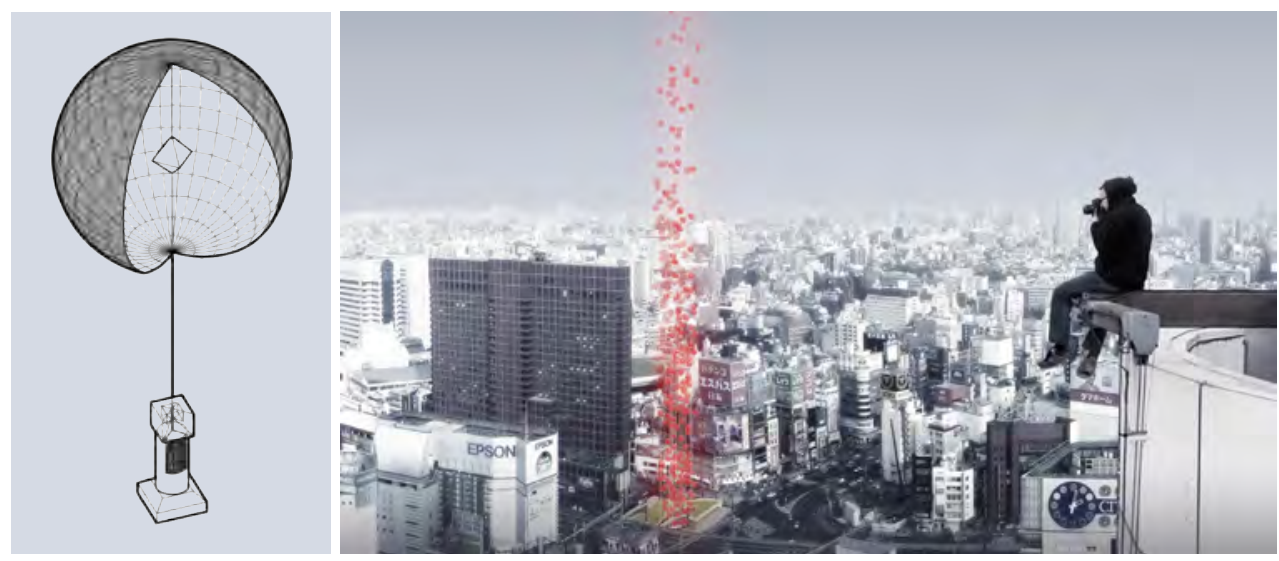

Img.49 a 50 Proposta vencedora de concurso internacional para um cemitério vertical em Tóquio A morte não é o fim, ser esquecido é (archoutloud.com)

Ainda, além dos processos que lidam com a destinação do corpo após a morte, é importante considerar os aspectos tecnológicos decorrentes da consolidação de meios virtuais. $\mathrm{O}$ uso constante de sites, aplicativos e redes sociais digitais representa um processo de extensão das práticas funerárias, introduzindo novos modos de relacionamento com os mortos. Um exemplo, é o uso de tecnologias digitais para a criação de páginas e redes digitais que oferecem túmulos virtuais acessíveis pela internet. Com isso, são estabelecidos novos meios de "deslocamento" aos "túmulos" e novas formas de se homenagear os entes queridos através da oferta de velas e flores virtuais. Renata Ribeiro (2015), ao discutir a relação entre morte e mídias digitais, destaca que o imaginário social acerca do lugar material de cuidado dos mortos tem grande influência na "arquitetura" digital. Esse aspecto pode ser verificado não apenas pela forma como as comunidades virtuais se utilizam dos símbolos funerários do cemitério, como as velas e flores, mas também pela opção à individualização dos túmulos virtuais. Ainda, Ribeiro ainda observa que as comunidades virtuais fornecem uma atualização constante da narrativa a partir das autobiografias formadas pelos "restos" digitais deixados pelos mortos, além dos relatos construídos pelos outros integrantes da comunidade. Nota-se como as relações virtuais têm alterado as formas de encadeamento do culto de visitação aos cemitérios, apontando para sua migração a uma versão digital. Ao prolongar a existência para além da morte, esses sites podem ser entendidos como "lugares" de perpetuação da memória, tornando o acesso a uma página online um novo recurso para se relacionar com os mortos. 
Esses "lugares" de manifestação de homenagens e lembranças dos mortos multiplicam-se desde a criação do World Wide Cemetery ${ }^{100}$, primeiro memorial virtual, criado em 1995. Também o Facebook, desde 2009, passou a transformar a conta de pessoa falecidas em uma conta de memorial que se torna fixa e acessível apenas aos amigos e parentes do falecido ${ }^{101}$. Nesse sentido, é possível refletir sobre a colocação feita pelo filósofo Thomas Macho (2007 apud THIOLLIERE, 2016) de que o protótipo do cemitério do futuro é um cemitério sem mortos, o cemitério virtual. Ainda assim, é importante destacar que apesar da crescente virtualização das relações e do declínio das visitas físicas aos cemitérios, os locais de repouso dos corpos exercem um papel indispensável. Saber onde estão os restos mortais e visualizar o seu lugar físico são questões fundamentais no processo mental de se lidar com a morte (THIOLLIERE, 2016). Portanto, a virtualização da morte encontra sentido através de uma relação de complementaridade com a existência de um lugar físico.

Nesse sentido, é possível compreender o porquê da multiplicação de propostas que se apoiam na realização de enterros que podem ser localizados por meio do sistema de posicionamento global (GPS). O GPS tem sido usado como recurso para identificar a posição de inumações realizadas, por exemplo, em terrenos de enterro natural. No entanto, esse gesto não deixar de ser paradoxal, pois assim como na proposta dos balões, aqui também a tecnologia é usada de modo a invisibilizar a morte, tornando-a conhecida apenas para aqueles que têm acesso aos dispositivos digitais. Neste, ao mesmo tempo em que se oculta a morte, é possível saber com precisão geográfica a localização de um corpo falecido.

Nota-se como a cada ano tem surgido alternativas que

100

Cf.

$<$ www.cemetery.org> Acesso em: 26 jan. 2018.

101

Cf. <www.telegraph. co.uk/technology/ facebook/6445152/

Facebook-introducesmemorial-pages-toprevent-alerts-aboutdead-members.html> Acesso em: 26 jan. 2018. tem como base os avanços tecnológicos. Enquanto algumas delas apresentam-se de modo promissor, precisando ser testadas e experimentadas, outras ainda se mostram atrelada apenas a aspectos científicos, funcionais ou até cênicos. Ao pensar sobre esse tema em uma perspectiva ampla, cabe refletir sobre a ambiguidade que representa a valorização da individualidade trazida por grande parte dos novos dispositivos, e sua restrição às diferenças e peculiaridades de cada singularidade. Assim, ao refletir sobre os meios pelo qual a morte irá se desenrolar nas próximas décadas, é fundamental saber diferenciar o universal e o universalizante. 


\section{Os espaços fúnebres no século XXI}

Desde o início do século XX, a cremação passou a apontar para as transformações dos meios de se lidar com a morte nas grandes cidades. Ainda assim, a arquitetura voltada a esse tema não foi desenvolvida de modo a criar linguagens próprias. Worpole (2003, p.189) conta que em 1901, quando Ernest George se dedicou a projetar um edifício para esse uso, observou que os "crematórios eram, afinal, um tipo de construção para o qual não havia precedentes arquitetônicos". Desse modo, era possível pensar a construção desses lugares de forma singular, uma arquitetura que poderia se estabelecer como um paradigma para a forma de tratar este assunto. No entanto, a maioria dos arquitetos acabou por elaborar edifícios de estilo gótico, associando a arquitetura dos crematórios com a estética religiosa de períodos anteriores. Assim, Edwin Heathcote (1999, p.38, tradução nossa) descreveu os projetos de crematórios, em sua maioria, como "um campo de oportunidades desperdiçadas". Para o autor, a arquitetura e o design de crematórios ficaram órfãos de elementos unificadores das formas ritual, processional e construída em relação à cremação.

Em um caminho distinto, foi visto como os novos métodos de tratamento do cadáver têm buscado soluções espaciais que estejam em consonância com suas características. Todavia, ainda é cedo para entender o quão efetivo esses novos procedimentos e linguagens se tornarão junto à sociedade e ao meio urbano. Especificamente em relação aos cemitérios, foi visto como o século XIX foi eficaz em estabelecer uma linguagem que teve como premissas enaltecer aspectos morais, contemplativos e a ideia de evocação da natureza. Também foi visto como ,com a chegada do século XX, ganhou lugar uma configuração mais racionalista dos cemitérios, que passaram a ser planejados de modo mais pragmático e utilitarista.

O roteiro a ser seguido pelo século XXI ainda está em aberto. Até o momento, nas primeiras décadas deste século, observa-se que há uma diversificação dos recursos e das conformações para se lidar com a morte e com os espaços fúnebres. Foram vistos alguns dos caminhos que têm sido apresentados até então: terrenos de enterro natural, construção de cemitérios edificados, projetos pensados a partir das ideias de paisagem, percurso e processo, formas de utilização de dispositivos tecnológicos. A partir dessas perspectivas, percebe-se um processo crescente de busca por pensar sobre o futuro dos cemitérios onde cada iniciativa busca, a seu modo, reconfigurar os espaços e lugares fúnebres. 
Tendo em mente refletir sobre esses encadeamentos, o próprio ato de se pensar sobre como reconfigurar o cemitério pode representar uma contradição. O vocábulo cemitério, em sua origem, está carregado de simbologias associadas a um tipo de configuração de espaço fúnebre. Do grego, koumenterion, e do latim coemeterium, eram os termos usados para designar o lugar onde se dormia, assim como o dormitório. Portanto, a palavra cemitério tem como raiz a ideia de repouso do corpo, está relacionada com a metáfora da morte como sono eterno. Procurando ir além dessa concepção, caberia então pensar: como os espaços que ultrapassam esse sentido poderiam ser chamados? Quais seriam as relações entre suas designações e seus desígnios?

Observa-se como, cada vez mais, tem se percebido os cemitérios como infraestruturas para a morte, de forma a abarcar as problemáticas de uma população global crescente, de disputa por espaços e das questões ecológicas. Ao mesmo tempo, as práticas e os espaços fúnebres revelam abordagens, atitudes e necessidades distintas e muitas vezes contraditórias, indo desde a minimização das questões de manutenção, até a profunda necessidade de atribuir aos mortos um lugar definido, capaz de apoiar a relação post mortem. Nesse sentido, o esforço para se pensar os espaços fúnebres se direciona no caminho de buscar equações onde a arquitetura, o paisagismo e o urbanismo são capazes de considerar de forma mais ampla as condições e as perspectivas referentes à questão da morte. Assim, pode-se imaginar espaços e lugares que podem abrigar sentidos múltiplos e dinâmicos que o tema coloca, como acolhimento, reflexão, contemplação, simbolismo, praticidade, sustentabilidade, entre outros. 


\section{O Cemitério da Vila Formosa}

\section{Ensaio-ensejo}

Cada espaço de cemitério apresenta suas peculiaridades e motivos de interesse no qual seria possível propor ricas discussões, no entanto, devido a quantidade e a variedade desses locais na cidade de São Paulo, foi preciso encontrar um ponto focal para esta dissertação. O Cemitério da Vila Formosa foi escolhido por possuir uma série de atributos relevantes: sua posição urbana, trajetória, escala e características físicas. Desse modo, ele se apresenta como uma referência, um local para onde converge uma diversidade de fatores relevantes para se pensar sobre os espaços de cemitério e a cidade.

Destaca-se que a opção pela palavra ensaio adotada neste trecho tem como intuito a comunicação de um texto mais discursivo, uma passagem que pretende apresentar e refletir sobre alguns pontos que este lugar apresenta. Decidiu-se, então, chamá-la também de ensejo de modo a reconhecer e enaltecer o Cemitério da Vila Formosa como 
espaço e lugar fundamental para possibilidades. Ainda, ressalta-se que não se deve entender este local como um estudo de caso, mas um objeto-paradigma, um meio para se discutir e enfatizar aspectos próprios desta dissertação, como a relação dos cemitérios com a cidade de São Paulo.

Como visto anteriormente, é difícil definir os espaços de cemitério a partir de uma compreensão ou percepção única. Ao pensar na imagem preponderante desses locais no cotidiano urbano, prevalece na sociedade brasileira uma configuração onde sua função não é apenas abrigar e simbolizar a morte, mas escondê-la. Como coloca Rodrigues (2006), oculta-se primeiro o cadáver, envolvendo-o em uma mortalha, que depois é colocado em um caixão, que por sua vez é fechado na sepultura ou enterrado sob a terra e, por fim, é colocado em um local cercado por muros configurado de forma pouco conexa ao seu entorno. Com isso em mente, surgem algumas questões para se pensar sobre essa problemática: como os cemitérios podem se aproximar mais do cotidiano da cidade? Como as pessoas podem ser convidadas a entrar nesse espaço? Como se acomodam nele? Quais posturas podem ser adotadas frente aos dispositivos de memória, religiosidade e luto destes lugares?
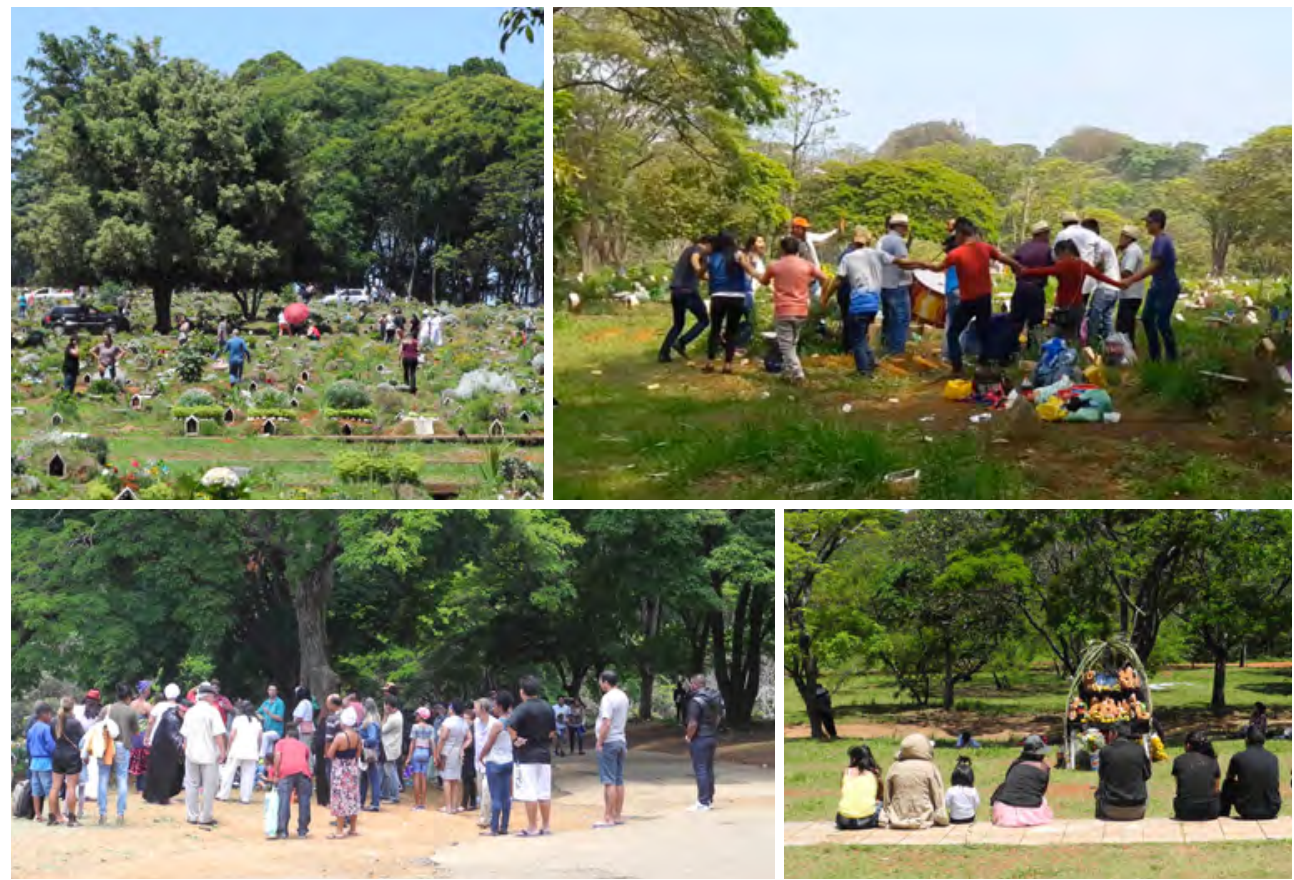

Img.51 a 54 Dia de Finados no Cemitério da Vila Formosa (fotos do autor) 
Pensando nas formas como esses locais podem ser usufruídos, é possível usar como referência o Dia de Finados, quando multidões de pessoas se deslocam aos cemitérios para homenagear e lembrar dos entes queridos mortos. Neste dia, as pessoas se dirigem a eles, depositam flores, acendem velas, fazem orações. Esse evento pode, então, ser entendido como um momento específico para manifestação pública de saudade e memória dos antepassados. Há uma efervescência em todos os espaços cemiteriais da cidade, independente do tipo de configuração, da região em que se encontra ou do público a que é destinado. Assim, para aqueles que se dedicam à temática da morte e do cemitério, o Dia de Finados é uma ocasião singular. Especificamente no Cemitério da Vila Formosa, percebe-se como o comércio de ambulantes se faz presente na região, fazendo com que o local assuma aspectos de uma grande feira. São realizados shows, cultos, danças, enfim, diversas atividades que buscam oferecer homenagens aos falecidos. O Vila Formosa se torna um espaço ainda mais fascinante. Centenas de milhares de pessoas usam o local que é tomado por manifestações culturais das mais diversas. Apesar de se instituir como uma festividade tipicamente cristã, o Dia de Finados ultrapassa as barreiras religiosas e
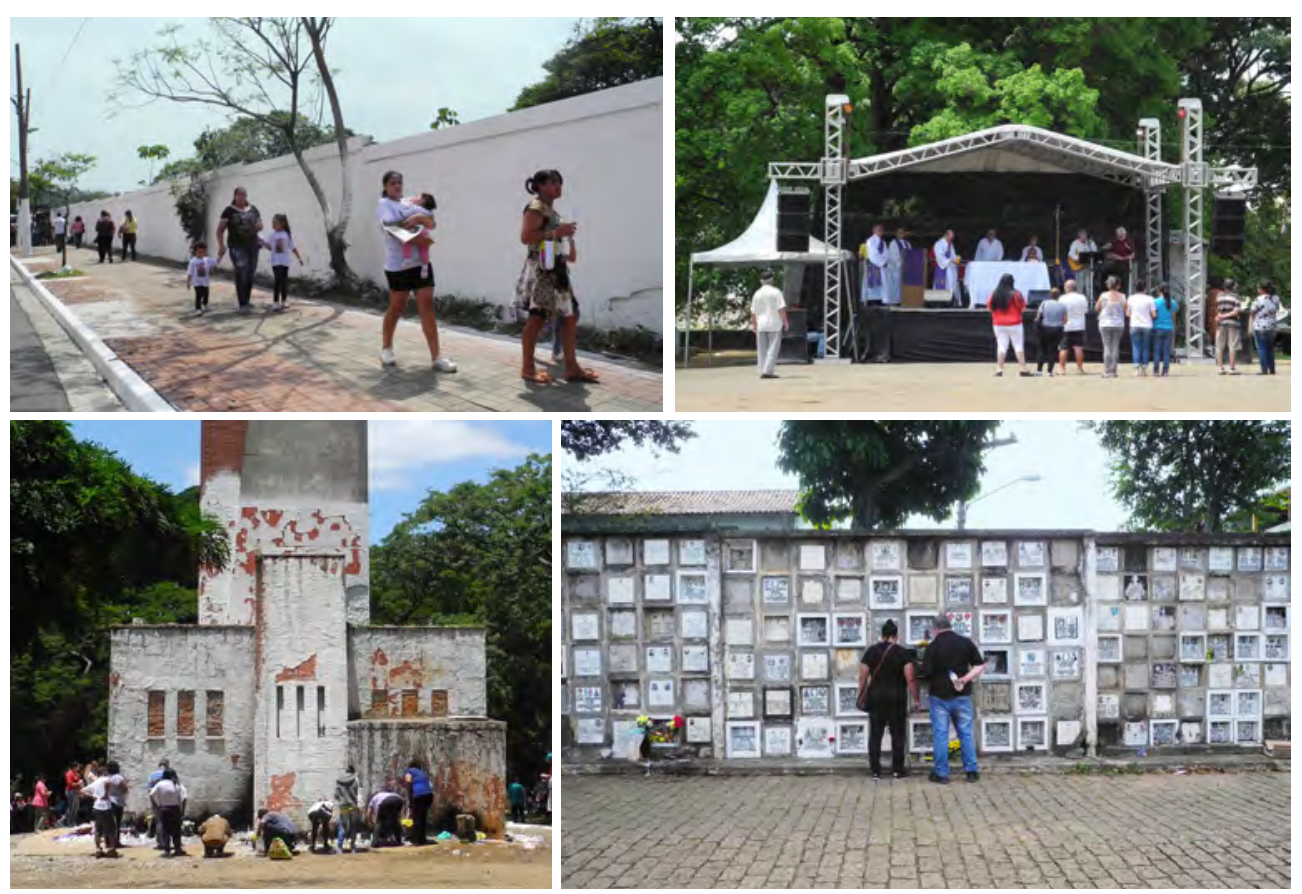

Img.55 a 58 Dia de Finados no Cemitério da Vila Formosa (fotos do autor) 
é celebrado por pessoas de todas crenças, inclusive por aqueles que se declaram sem religião. Nessa data, diferente de outros momentos do ano, as diferenças convivem de forma espontânea e amistosa, talvez pela percepção que todos estão juntos neste momento para refletir e encontrar formas de se lidar com a morte.

As imagens feitas no local nos Dias de Finados de 2017 e 2018 podem ajudar a entender parte da ambiência e da profusão que se fazem presentes nesses eventos, ainda assim, nenhuma imagem é capaz de reproduzir a experiência que pode ser sentida no local. O Dia de Finados representa uma transformação da realidade cotidiana do cemitério, um momento intenso de aproximação e encontro de variadas percepções. O reconhecimento desta amplitude pode ajudar no estudo das atividades, comportamentos e formas de uso de um cemitério como o Vila Formosa, reforçando o carácter excepcional que o faz complexo e fascinante. Percebese, nestes dias, o enorme potencial que ele possui ao deixar de ser um lugar desconexo para se tornar, junto aos outros cemitérios, um espaço vital da cidade. Assim, o Dia de Finados pode ser entendido simbolicamente, como o ponto de partida e de chegada deste tópico. Partindo dele, enseja-se por mais "Dias de Finados" ao longo do ano para este local.

Desse modo, tendo como base as incursões etnográficas realizadas no Cemitério da Vila Formosa entre julho de 2017 e novembro de 2018, este trecho da dissertação parte de uma apreciação do lugar para, na sequência, imaginar possibilidades de se interpretar e atuar nesse espaço. Ainda, destaca-se que a opção pela noção de possibilidades procura diferenciar-se da busca por respostas determinantes, como se houvessem soluções ou resoluções precisas e únicas para este local. Portanto, a ideia de possibilidades visa incitar e contribuir à reflexão sobre as formas de se relacionar com esse lugar e assim, eventualmente, ampliar a abrangência e reconhecimento deste local junto ao seu contexto urbano. 


\section{Img.59}

Visitante cuidando de túmulo no Dia de Finados, Cemitério

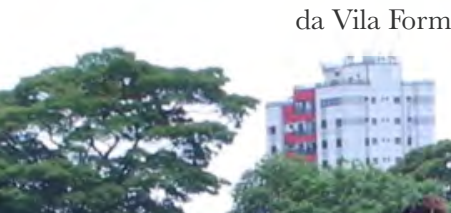

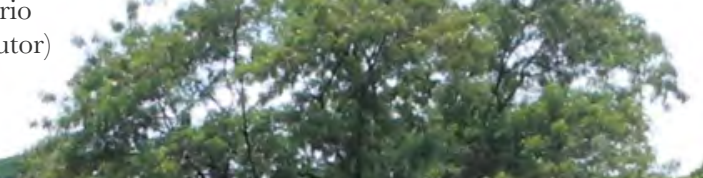

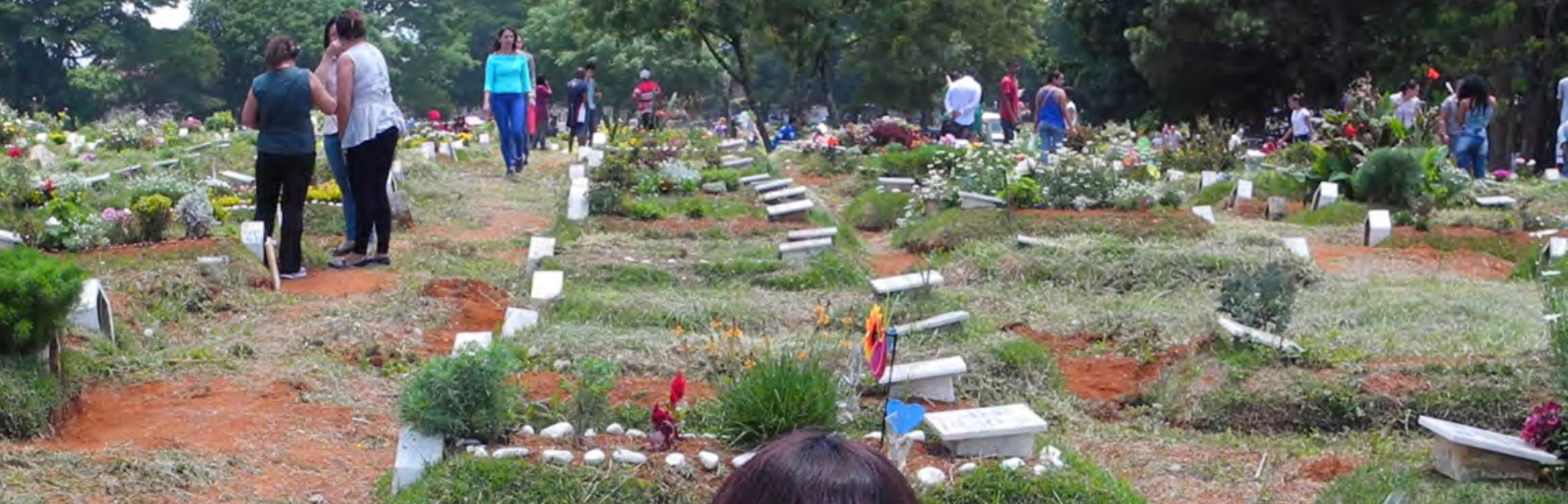

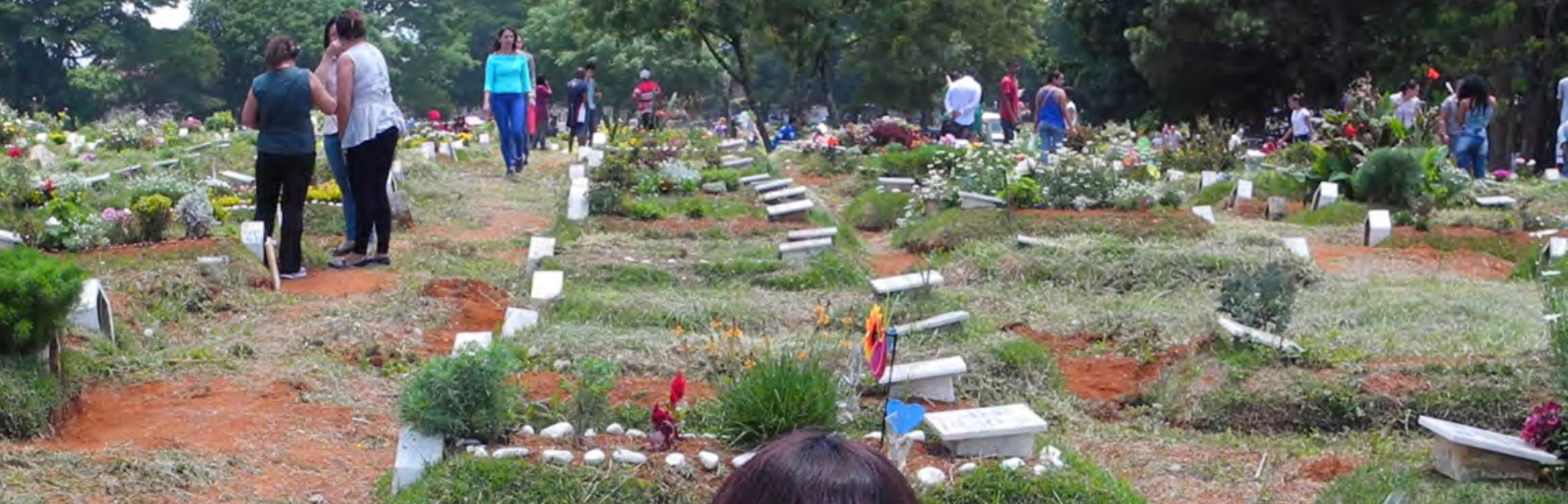
s.t. ex

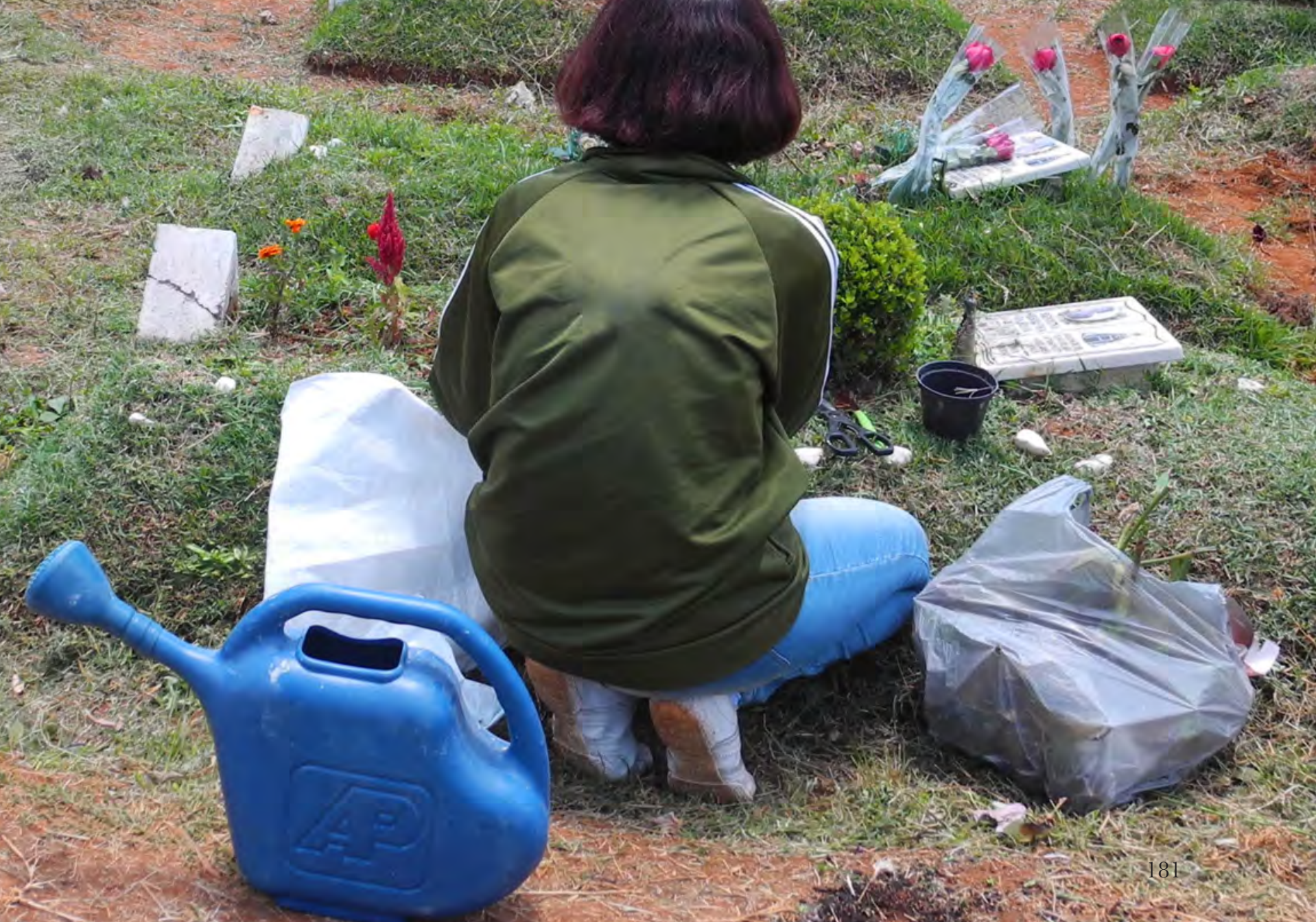


CEMITÉRIO

- Acessos abertos

- Acessos fechados

- Córrego Água Rasa

1a Administração e capela (V. Formosa I)

1b Administração e capela (V. Formosa II

2a Cruzeiro (V. Formosa I)

2b Cruzeiro (V. Formosa II

3 Homenagem à Débora

4 Velório

\section{ENTORNO}

A Terminal de ônibus

B Reservatório (piscinão)

C Sociedade Esportiva Flor de Vila Formosa

D Externato Nossa Sra do Coração Sagrado
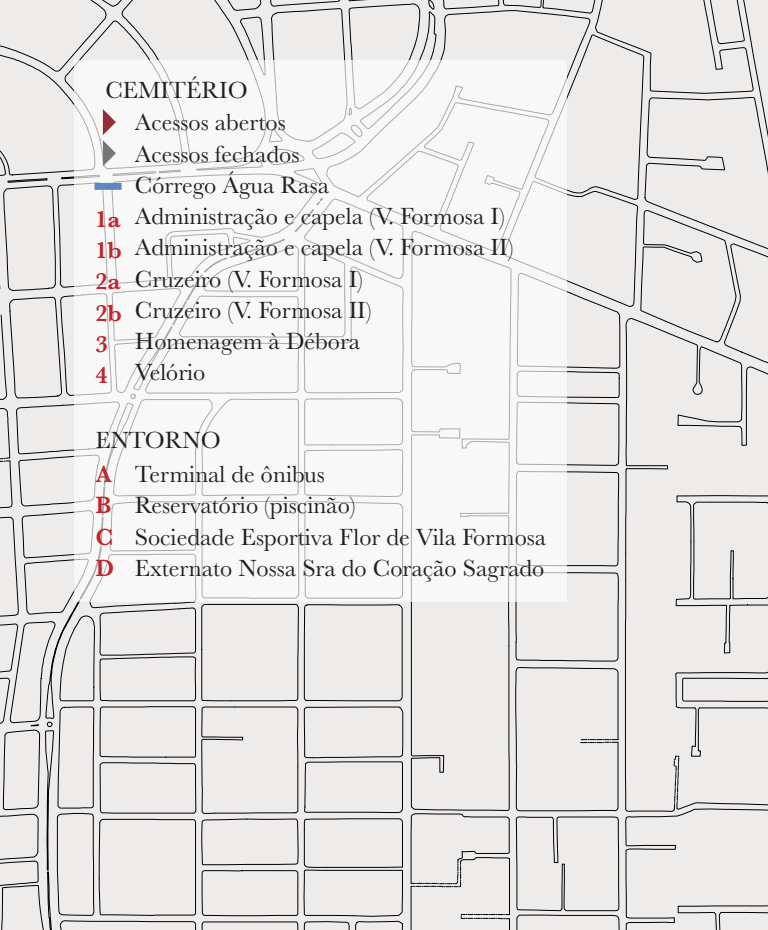


\section{$\underline{\text { O Cemitério }}$}

O Cemitério da Vila Formosa está situado no subdistrito do Aricanduva-FormosaCarrão, zona leste de São Paulo. A região foi um importante núcleo industrial na virada para o século XX, tendo passado por grandes mudanças na sua morfologia a partir da década de 1920, quando viu a substituição de seus galpões industriais por núcleos residenciais. O cemitério foi criado ao fim desse processo, em 1949, ocupando o lugar de uma antiga fazenda. Nesse momento, ele era composto pelo terreno que hoje é o Formosa I, sendo reformulado e ampliado em 1976, com a incorporação da área do Formosa II. Assim, ele é composto por dois cemitérios conjugados, o Vila Formosa I e o Vila Formosa II, que juntos ocupam um enorme quarteirão de $763.175 \mathrm{~m}^{2}$, o que faz do cemitério a $4^{\mathrm{a}}$ maior área de propriedade do município ${ }^{102}$ e o maior cemitério da América Latina ${ }^{103}$.

Seu espaço é caracterizado pela presença de extensos gramados e ampla arborização, sendo o cemitério integrante do movimento de ampliação dos cemitérios tipo jardim em São Paulo. Devido à sua dimensão e configuração como área ajardinada e arborizada, o Vila Formosa é considerado o pulmão da região, contribuindo para a preservação de fauna e flora na região. Em termos de seu funcionamento, ele foi destinado a populações de mais baixa renda, principalmente para as classes C, D e E, abrigando em seu interior aproximadamente 120.000 sepulturas e 105.000 ossários ${ }^{104}$. A sua administração estima que já foram realizados mais de 1.500 .000 sepultamentos no local, sendo que ele responde a mais de $1 / 4$ dos enterros diários da cidade ${ }^{105}$. Desse modo, o Vila Formosa se apresenta como uma infraestrutura urbana indispensável na logística fúnebre do município. Esse número significativo é possível graças à rotatividade

102 Ele fica atrás apenas do Parque Anhanguera, Parque do Carmo e do Parque Ibirapuera. Dados oficiais da SVMA, disponíveis em <www.prefeitura.sp.gov.br/cidade/secretarias/meio_ambiente/parques> Acesso em: 2 out. 2017.

103 O título de maior cemitério da América Latina é também atribuído ao Cemitério Nueva Esperanza, em Lima, no entanto, ao se comparar os dados oficiais, o Vila Formosa possui aproximadamente $763.000 \mathrm{~m}^{2}$ ante aproximadamente $600.000 \mathrm{~m}^{2}$ do Nueva Esperanza.

104 Dados do Portal Terra, "Vila Formosa: veja a estrutura do maior cemitério brasileiro". Disponível em $<$ www.terra.com.br/noticias/brasil/cidades/cemiterio-vila-formosa-veja-a-estrutura-do-maior-cemiterio-brasileiro, 612771f68d52282bba38ab0b6c0ddf9f2snmRCRD.html> Acesso em: 4 jul. 2017.

105 A cidade de São Paulo registra aproximadamente 230 mortes por dia, das quais o Vila Formosa recebe, em média, 60 enterros por dia. 


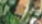

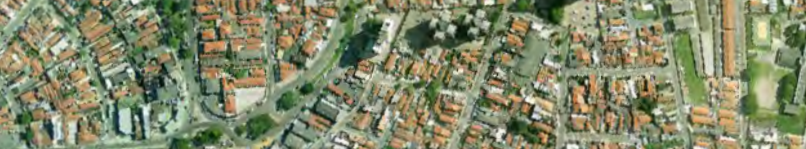

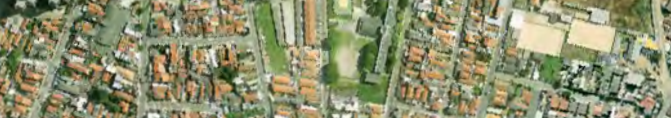
TII E

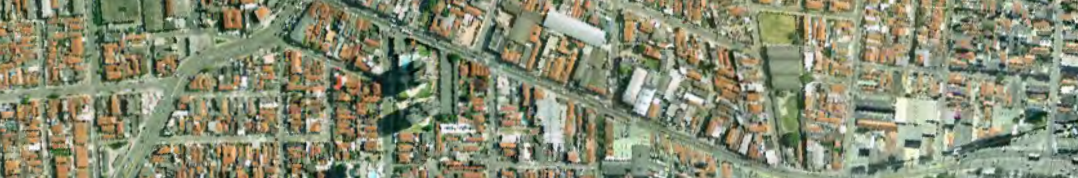

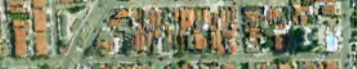

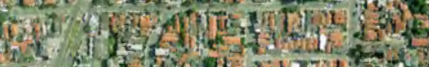

a 1

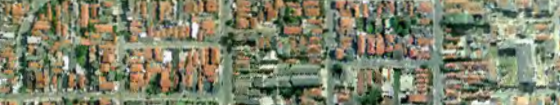

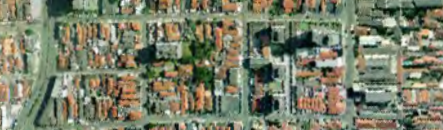

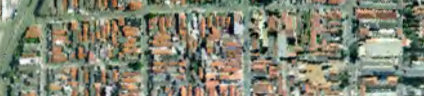

1.6. What

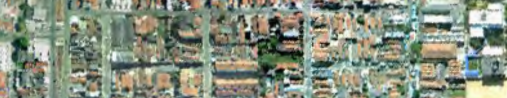

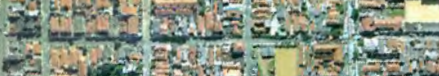

3.75

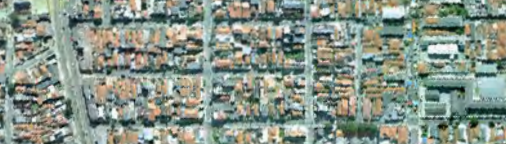

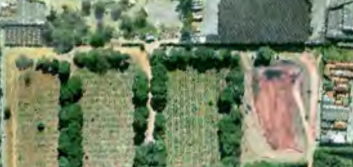

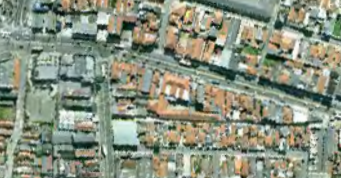

al axparat

$\rightarrow 4$
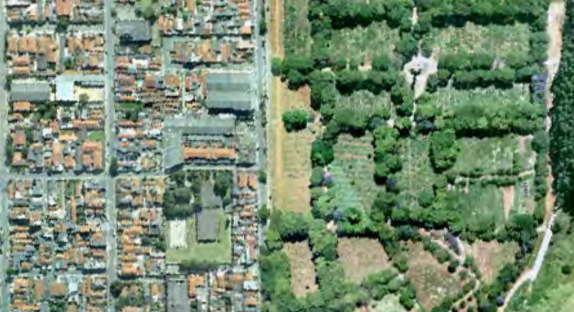

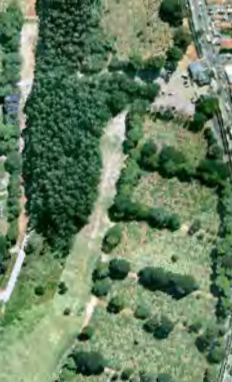

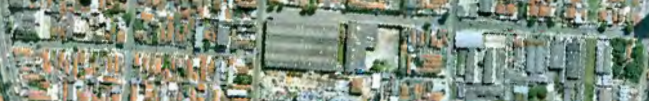

7.

12

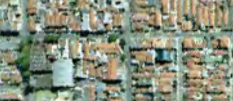

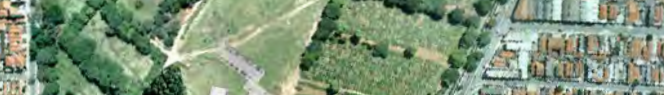

Fy

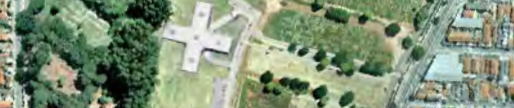

-1.52 .

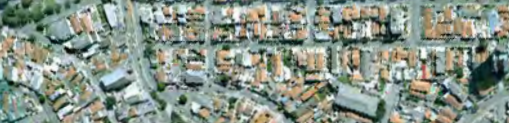

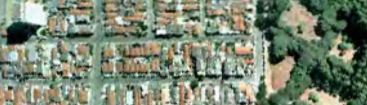

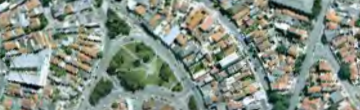

(1)
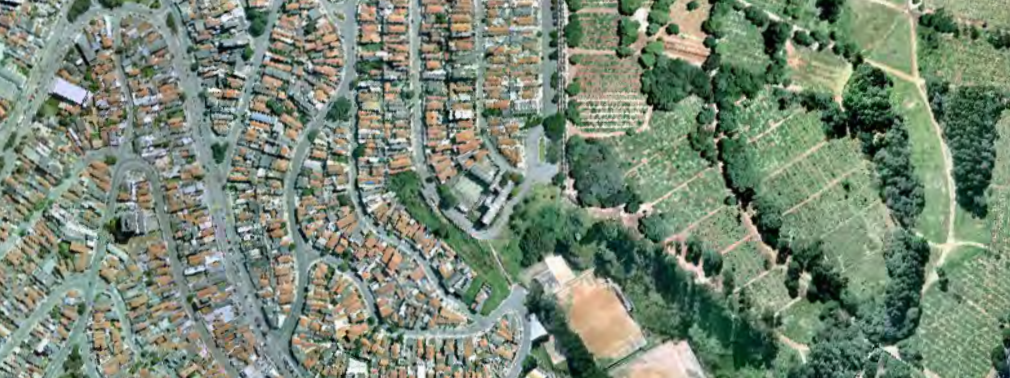

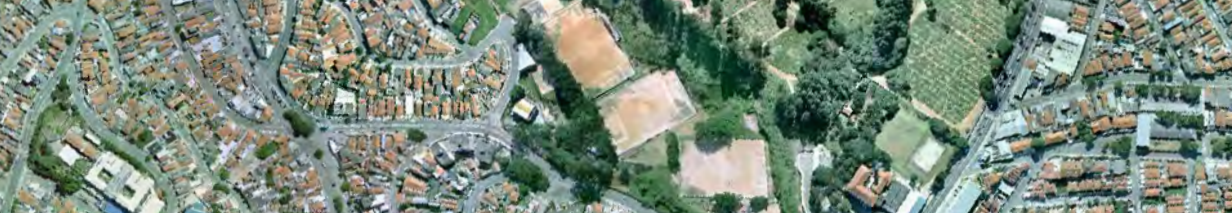

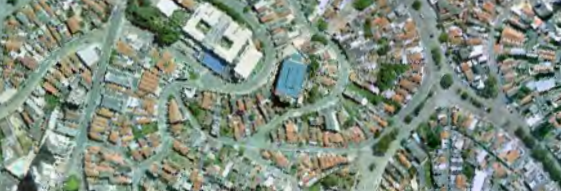

12

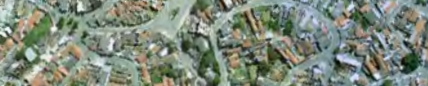

11

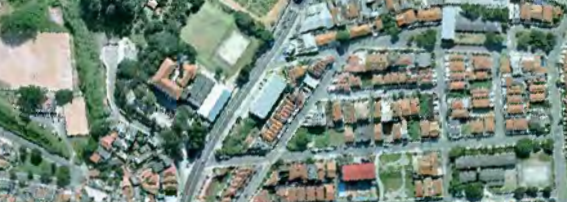

II Img.61

148

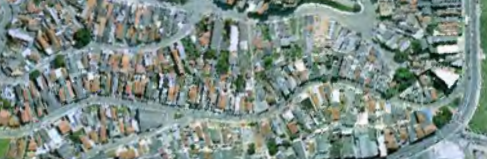

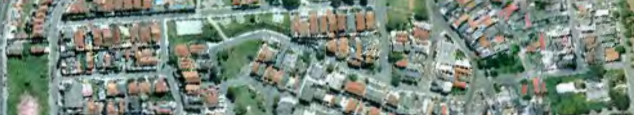

(15) 1 t)

15. $2-2-25$

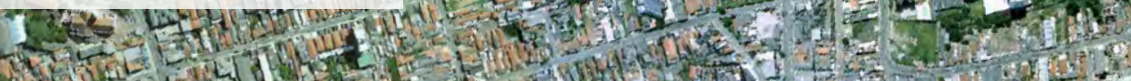


da maior parte dos perímetros de sepultamento, que são reutilizados a cada 3 anos, quando podem ser realizadas as exumações dos enterrados. Para tal, é preciso haver a presença de um familiar, sendo que em seguida é feito o encaminhamento dos restos mortais para os ossários, que possuem um valor de arrendamento relativo a cada 5 anos de uso. Como visto anteriormente, apenas o Vila Formosa e o Cemitério São Luís possuem esse sistema de rotatividade, que fica restrita às populações de baixa renda da cidade que costumam utilizar estes locais.

Ainda, como visto no tópico (7) Cemitérios de São Paulo, o Vila Formosa é organizado pelo sistema de quadras gerais, com covas de terra, não sendo permitidas construções tumulares à maneira dos cemitérios tradicionais. As quadras são divididas entre adultos e crianças, sendo que um corpo de até $1.10 \mathrm{~m}$ de altura é considerado criança. Além dessas duas categorias, uma parte das quadras é destinada ao sepultamento de indigentes e pessoas sem familiares. Em alguns casos, essas quadras parecem extensos gramados onde é difícil notar que foram realizados enterros no local, enquanto que em outros, é possível ver uma ondulação do gramado que segue a proporção das covas, indicando que a terra foi mexida, mas sem nenhuma identificação. Em geral, as sepulturas são feitas através da criação de campas de terra, elevadas cerca de 40 centímetros do solo.

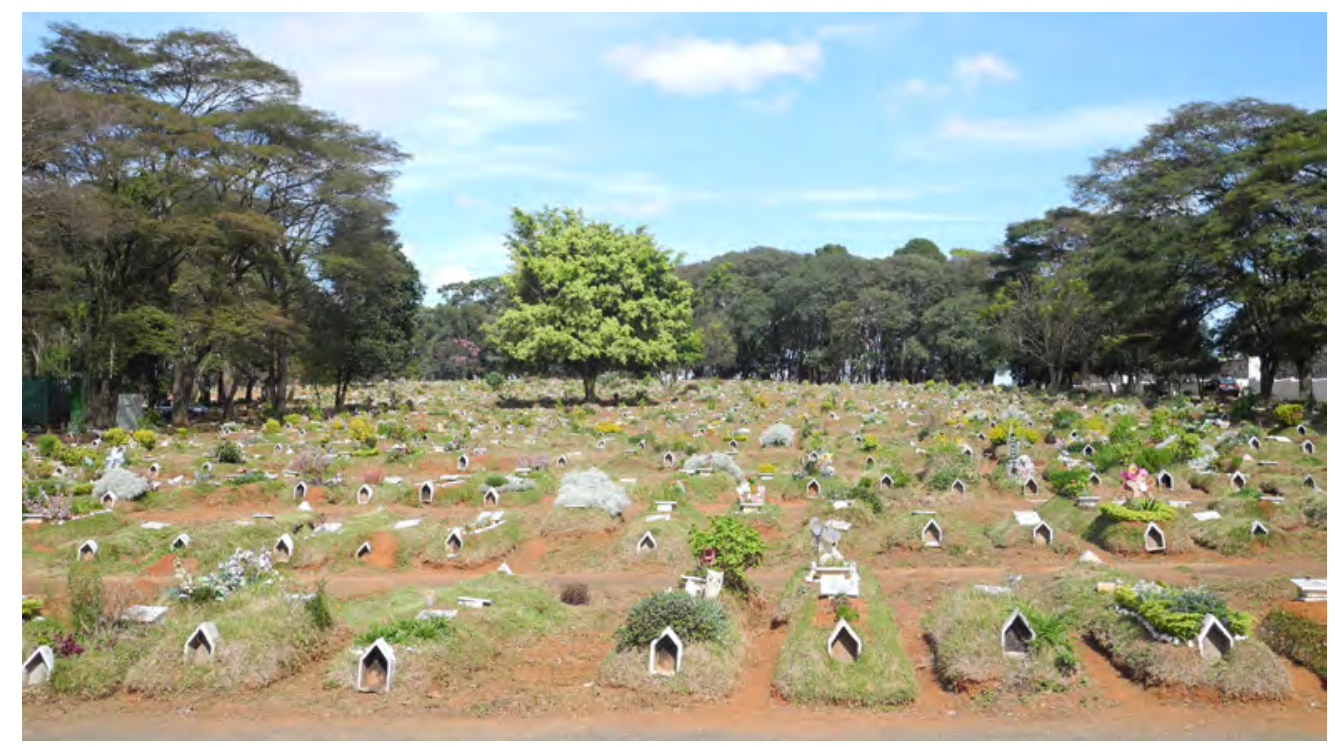

Img.62 Vista de uma quadra e das campas de terra (foto do autor) 
Entre as dezenas de quadras do cemitério, destaca-se uma área dedicada a Débora Campos de Oliveira, conhecida como Menina Débora. Ela ganhou a condição dos chamados santos milagreiros, presentes em muitos cemitérios brasileiros, devido à sua história marcante. Débora passava o dia na casa de uma vizinha enquanto sua mãe ia trabalhar. A vizinha, ao suspeitar do carinho que seu marido sentia pela menina, teve um ataque de ciúmes e assassinou a criança. Isso ocorreu em 1983, quando Débora tinha cinco anos. Devido a repercussão de sua trágica história, não tardou para que seu local de enterro virasse ponto de peregrinação. Desde então, muitos visitam o local para fazer pedidos para a menina. Sua sepultura está cercada de placas de ex-votos e de veneração. Ainda, é possível encontrar diversos presentes que os visitantes deixam no local, em maior parte, flores e doces. O movimento no seu túmulo passou a ser tão grande que a administração do cemitério decidiu reservar toda a quadra para Débora.

A paisagem das quadras ainda é marcada pela presença dos ossários, extensas paredes formadas por nichos de aproximadamente $30 \mathrm{x} 30 \mathrm{~cm}$ onde são depositados os restos mortais dos cadáveres após a exumação. Apesar de haver alguns núcleos de ossários distribuídos dentre as quadras, a maior parte deles está localizada junto aos muros que circundam o cemitério. Eles conformam grandes extensões de parede para as ruas adjacentes, deixando poucos pontos de conexão. Existem apenas quatro acessos possíveis para um local com perímetro de mais de 4 quilômetros lineares. Também fazem

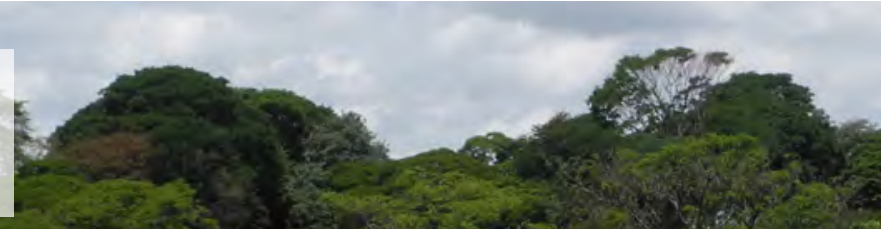


parte da paisagem da área das quadras os Cruzeiros das Almas, locais onde são acesas as velas dedicadas aos finados. O Vila Formosa possui dois cruzeiros, situados próximos aos acessos principais de cada unidade, um deles composto por um volume em formato de cruz, construído sobre o solo, e o outro uma torre de aproximadamente 40 metros de altura. Além desses espaços, cada uma das unidades do cemitério possui as sedes administrativas e, próximas a elas, estão as "capelas" onde são realizadas rezas e cerimônias de homenagem. O edifício de velório também possui uma planta em cruz, estando localizado na porção central do terreno, de modo a atender melhor as duas unidades do cemitério.

Do ponto de vista dos usos e apropriações do local, o Vila Formosa recebe mais de 30 mil visitantes por mês, considerando apenas os dados daqueles que vão ao local para participar de funerais e visitar os entes queridos. No Dia de Finados, esse número pode chegar a mais de 500 mil $^{106}$. Além desses visitantes, como visto no tópico (22) Intersecções: Coexistência, Limiares, o local também é frequentado por pessoas que exercem atividades não relacionadas à questão fúnebre. De modo a entender a dinâmica resultante dessas interações nos dias atuais (fevereiro de 2019), foram realizadas incursões etnográficas ${ }^{107}$ que buscaram entender as diferentes formas

106 Dados estimados, obtidos em conversa junto à administração do Cemitério da Vila Formosa.

107 Para tal, buscou-se aproximar da metodologia "de perto e de dentro" conforme indicado por José Guilherme Magnani (2002, 2012). de percepção dos espaços do Vila Formosa.

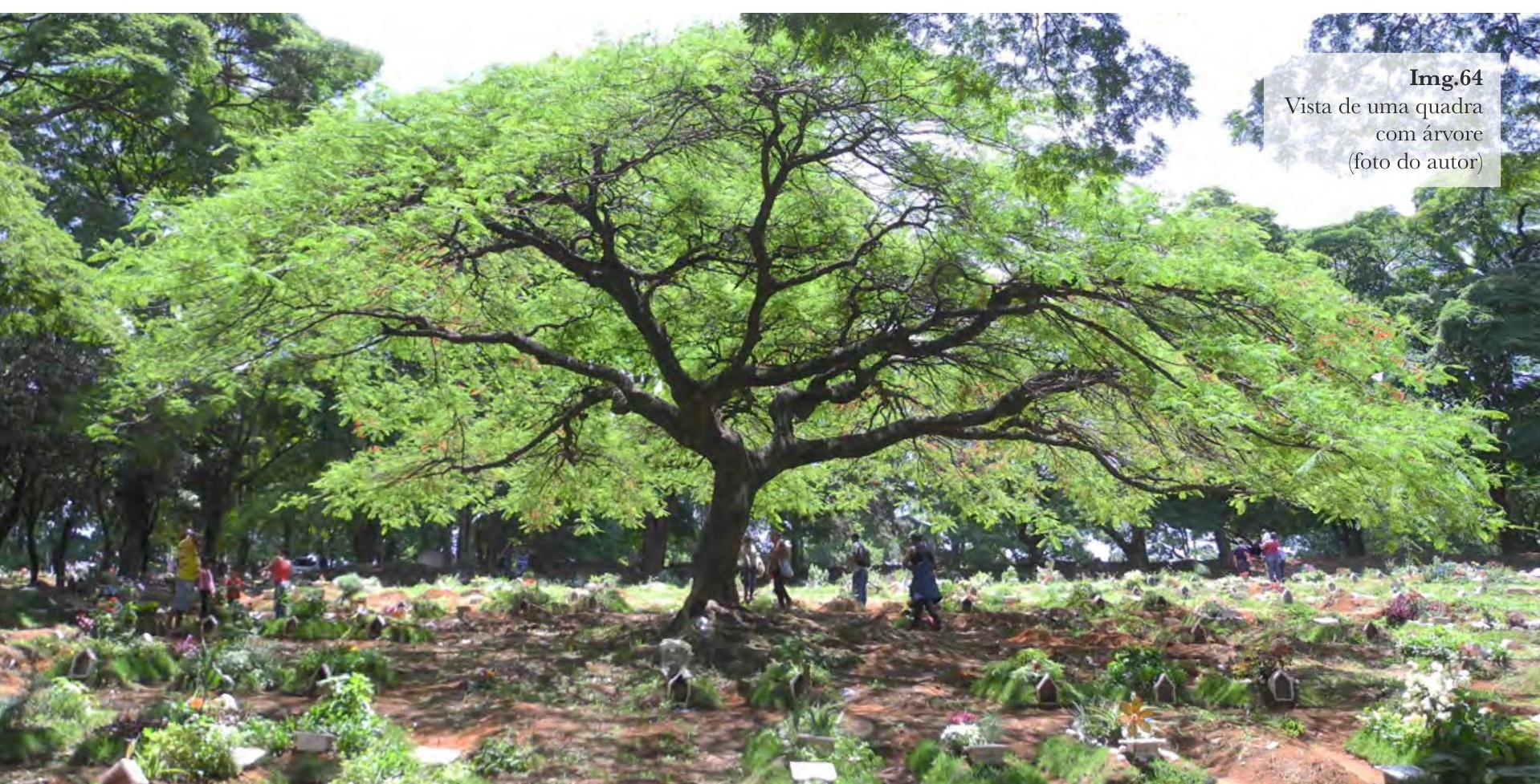


A partir delas, constatou-se que existem três grupos principais de frequentadores: os trabalhadores locais, os frequentadores previstos e os frequentadores imprevistos. Percebeu-se que os trabalhadores locais são, em sua maioria, funcionários do município ou autônomos autorizados pelo Serviço Funerário que obtém sua subsistência a partir das atividades realizadas no cemitério. Os frequentadores previstos são aqueles que frequentam o local devido a questões relacionadas à função fúnebre do cemitério, como as pessoas que estão participando de funerais, sepultamentos, realizando uma visita a um ente querido ou ainda resolvendo trâmites relacionados a algum processo funeral. Quanto aos frequentadores imprevistos, são aqueles que usam os espaços do cemitério para as atividades não relacionadas a realização dos funerais e sepultamentos.

O maior número de trabalhadores locais encontrados são os autônomos, basicamente os jardineiros e seus auxiliares. Para exercer a profissão, é preciso ter realizado um curso e fazer um cadastrojuntoà Prefeitura. Eles são os responsáveis por cuidar das milhares de campas do cemitério, sendo sua contratação recomendada, mas não obrigatória. Em virtude do tamanho do Vila Formosa, a maior parte dos jardineiros possui um carro próprio que é usado tanto para deslocamento como para depósito de ferramentas. É possível encontrar jardineiros que estão há mais de 30 anos no local e que mostraram ser grandes conhecedores da história do local.

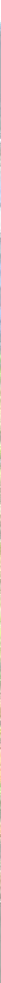


Além dos autônomos, outros trabalhadores encontrados são os funcionários do Serviço Funerário que normalmente ficam próximos à administração e aos enterros em procedimento. A maior parte deles são os coveiros, responsáveis pela exumação e escavação das novas sepulturas. Ainda, podem ser encontrados funcionários de cargos administrativos que acompanham as atividades do local. Bem menos numerosos são os trabalhadores que se ocupam de tarefas secundárias, como a coleta de parafina das velas que é trocada por uma quantia de dinheiro junto à indústria. Também, próximo aos acessos, é possível encontrar os vendedores de comidas e bebidas que buscam atender ao público frequentador do local.

Quanto ao grupo de frequentadores previstos, ele é composto por toda a população que vai ao local para os enterros, para visitar familiares e amigos mortos e para realizar rezas ou rituais destinados a eles. Devido à sua localização e forma de funcionamento, é mais comum encontrar no Vila Formosa pessoas oriundas de classes sociais mais baixas. É possível encontrar um conjunto bastante variado de pessoas, o que decorre em uma grande diversidade de formas de atuação e comportamento. Assim, encontra-se desde aqueles que se direcionam especificamente para os locais de enterro ou ossários, até aqueles que realizam manifestações junto a outros espaços dos cemitérios, como os cruzeiros e os bosques. Os seguidores de práticas religiosas derivadas do cristianismo, costumam

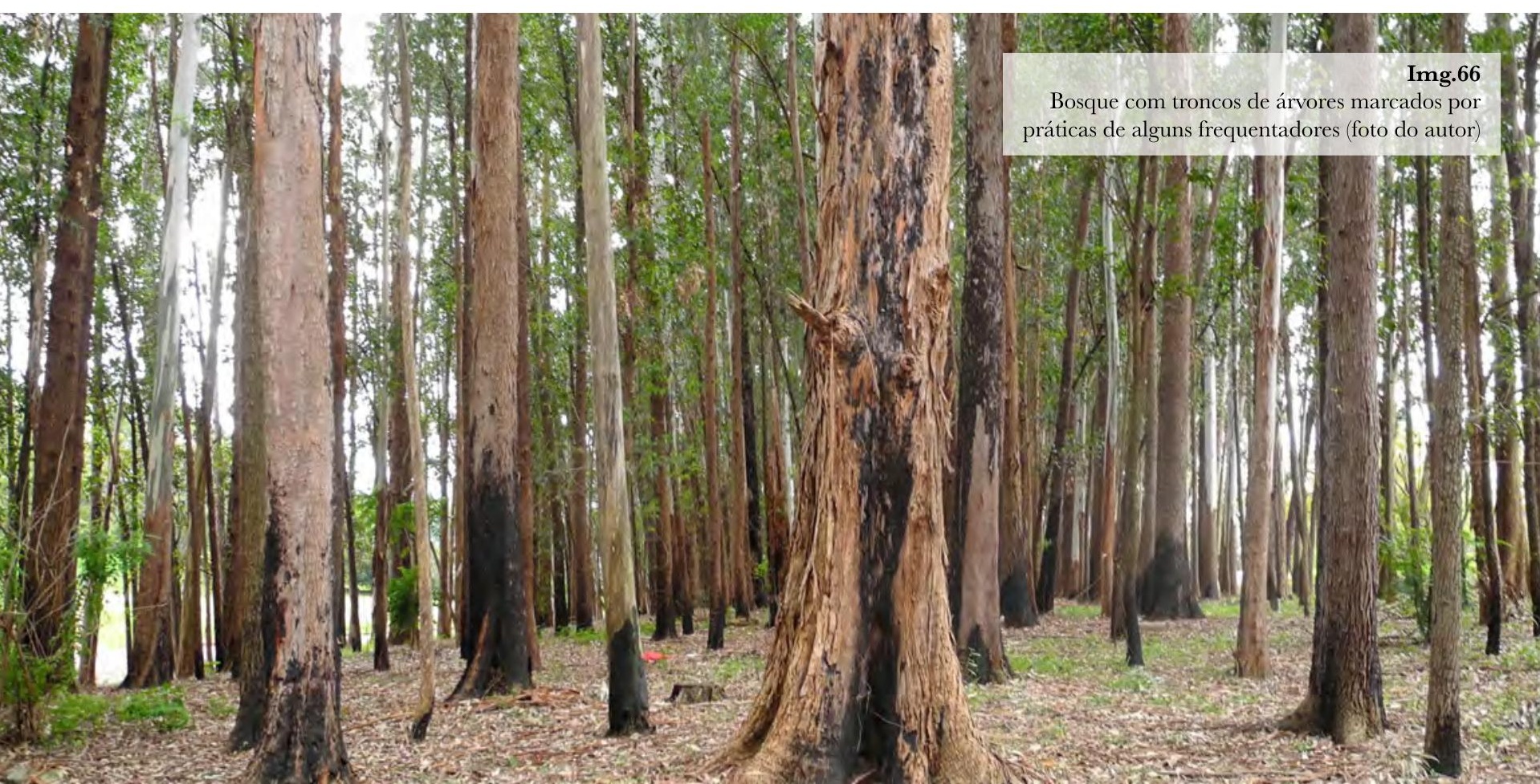


dirigir-se especificamente ao local de destinação dos restos mortais, levando artigos como cataventos, flores e objetos pessoais para serem colocados junto a esses pontos. Normalmente, eles demonstram uma preocupação maior com o cuidado das campas, demandando o cultivo dos jardins que são feitos sobre elas. Ao mesmo, tempo, ao longo de toda a extensão do cemitério, é marcante a presença de manifestações relacionadas a outras formas de práticas espirituais e religiosas que podem ser notadas pelos potes cerâmicos, bebidas alcoólicas, comidas e flores deixados nesses lugares. Usualmente realizadas por adeptos do umbandismo, elas costumam ser destinadas aos Exus e Pombagiras, tendo o intuito de alcançar pedidos realizados por seus praticantes. Os despachos, como são chamados, são mais frequentes nas áreas de bosque e junto aos cruzeiros. Apesar de não haver nenhuma sinalização relativa a proibição dessas atividades, em geral, eles não são bem vistos pelos trabalhadores locais e pelos frequentadores de outras crenças, que costumam reclamar da falta de higiene que eles ocasionam. Boa parte dessas manifestações costuma ser realizada à noite ou de madrugada, sendo possível encontrar aberturas em partes do muro do cemitério, que funcionam como uma espécie de entrada clandestina ao local. Nesse sentido, destacase a diferença entre as atividades realizadas quando o cemitério está em horário de funcionamento e quando não está. Após o fechamento de seus portões oficiais, revelase uma vida noturna paralela, cheia de rituais e apropriações do espaço.

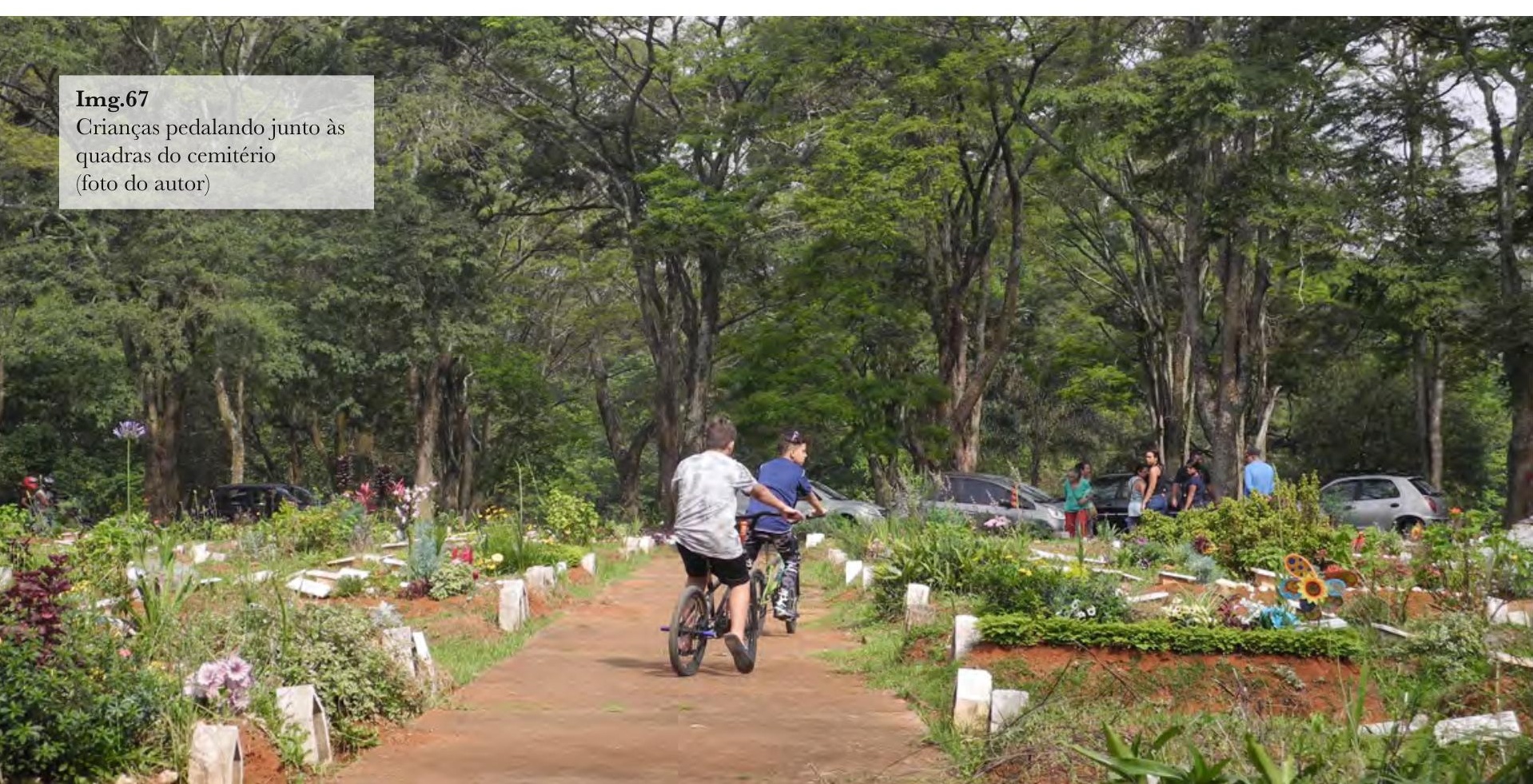


Já os frequentadores imprevistos, referem-se às pessoas que realizam vários tipos de atividades não relacionadas ao caráter fúnebre do local, formando um conjunto bastante diverso. Sabendo da prática de realização dos despachos, diversos moradores de rua buscam o cemitério para aproveitar as comidas e bebidas deixadas no local. Ainda, sabendo da pouca vigilância no cemitério, eles encontram certo isolamento que facilita tanto o consumo de bebidas alcoólicas como de drogas. Outra atividade que se aproveita desses aspectos é o namoro e a prática sexual, como relatado pelos trabalhadores do local. Neste caso, ela costuma ser efetuada por jovens que não possuem condições financeiras de ir a um motel e encontram no Vila Formosa uma alternativa para o encontro. Já em relação aos frequentadores imprevistos mais habituais, é possível encontrar atividades menos impróprias, como corrida, alongamento, ciclismo e passeio com animais de estimação. Nesse sentido, foi possível perceber como essas apropriações seguem como lógica uma espécie de repartição nômade das áreas do cemitério. Devido à rotatividade dos espaços de sepultamento, é normal que as quadras do cemitério sejam utilizadas setorialmente, concentrando-se em trechos específicos ao longo do tempo. Sabendo disso, parte dos frequentadores que praticam atividades como a corrida e o ciclismo costumam estar atentos às quadras em uso vigente, evitando assim passar por esses locais. Eles costumam definir seu itinerário conforme a mobilidade das áreas de sepultamento, estabelecendo uma

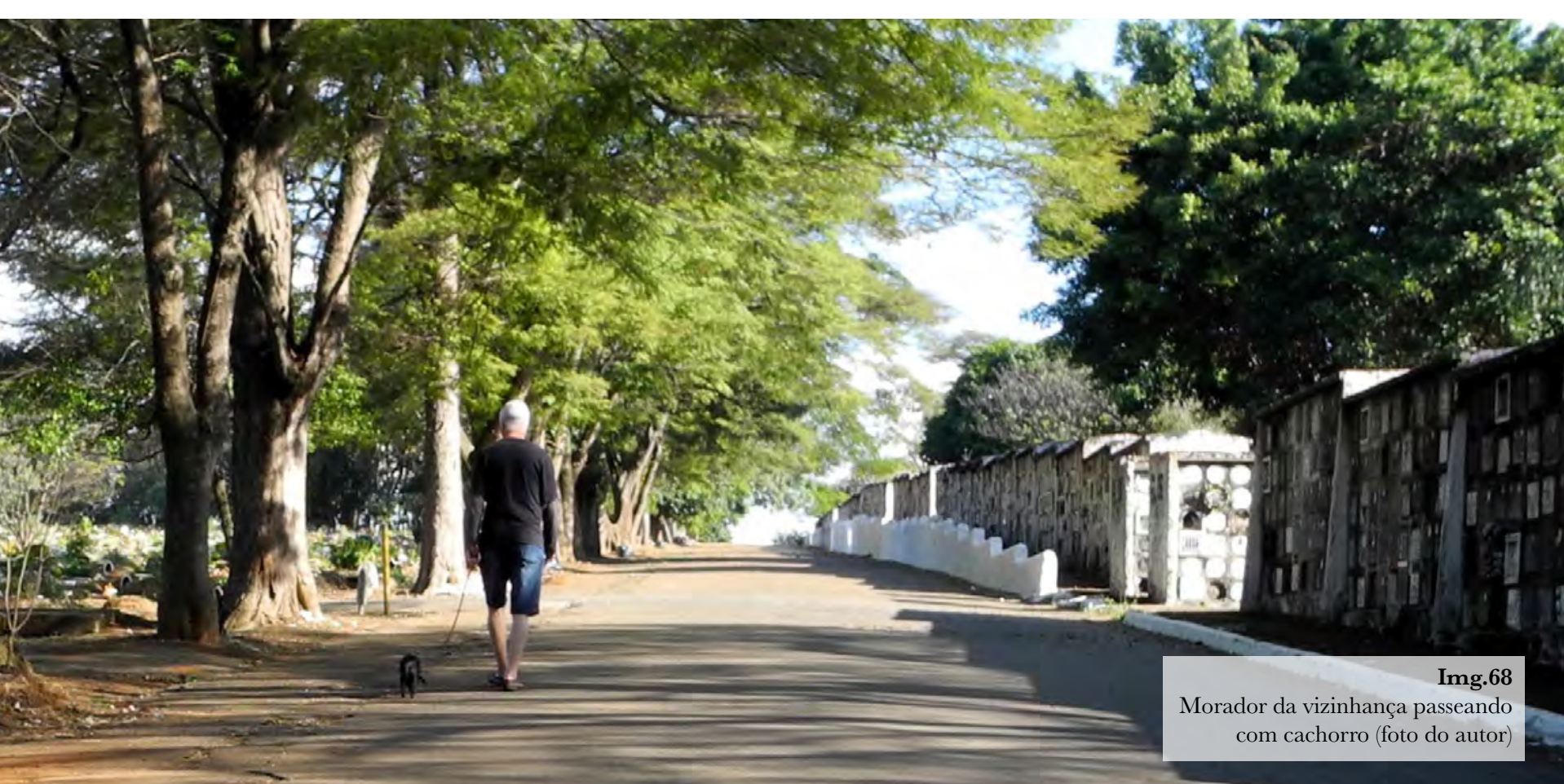


relação de mutualidade consciente de uso do espaço do cemitério. Normalmente, essas atividades são realizadas por moradores do entorno próximo que enxergam no cemitério um espaço arborizado e com ar puro adequado para essas práticas. Nota-se, pelos mapas de Tipos Socioambientais (img.69) e de Cobertura de Acesso a Lazer e Cultura (img.70) que a oferta por essas qualidades e por ambientes para usufruto de recreação e cultura em São Paulo concentra-se nas regiões centrais e sudoeste da cidade. Devido à falta de praças, parques e equipamentos de lazer e cultura com essas características na região próxima, o cemitério assume um papel importante na dinâmica regional. A arborização do cemitério também atrai frequentadores que buscam amoreiras, goiabeiras e pitangueiras para colher frutos. Ainda, é possível encontrar quem vá ao local em busca de pássaros, alguns para alimentar e outros para levar para casa e cuidar. A presença marcante de árvores e pássaros no Vila Formosa levou, inclusive, o Serviço Funerário a colocar placas informativas a respeito das espécies encontradas. Isso foi feito concomitantemente a instalação

\section{Img.69}

Mapa de Tipos

Socioambientais (PMSP)

Altos valores de cobertura vegetal e conservação da biodiversidade

Alto adensamento vertical, pode apresentar altos valores de cobertura vegetal

Baixíssima presença de cobertura vegetal em áreas de ocupação urbana consolidada

Alta precariedade urbana com remanescentes de vegetação

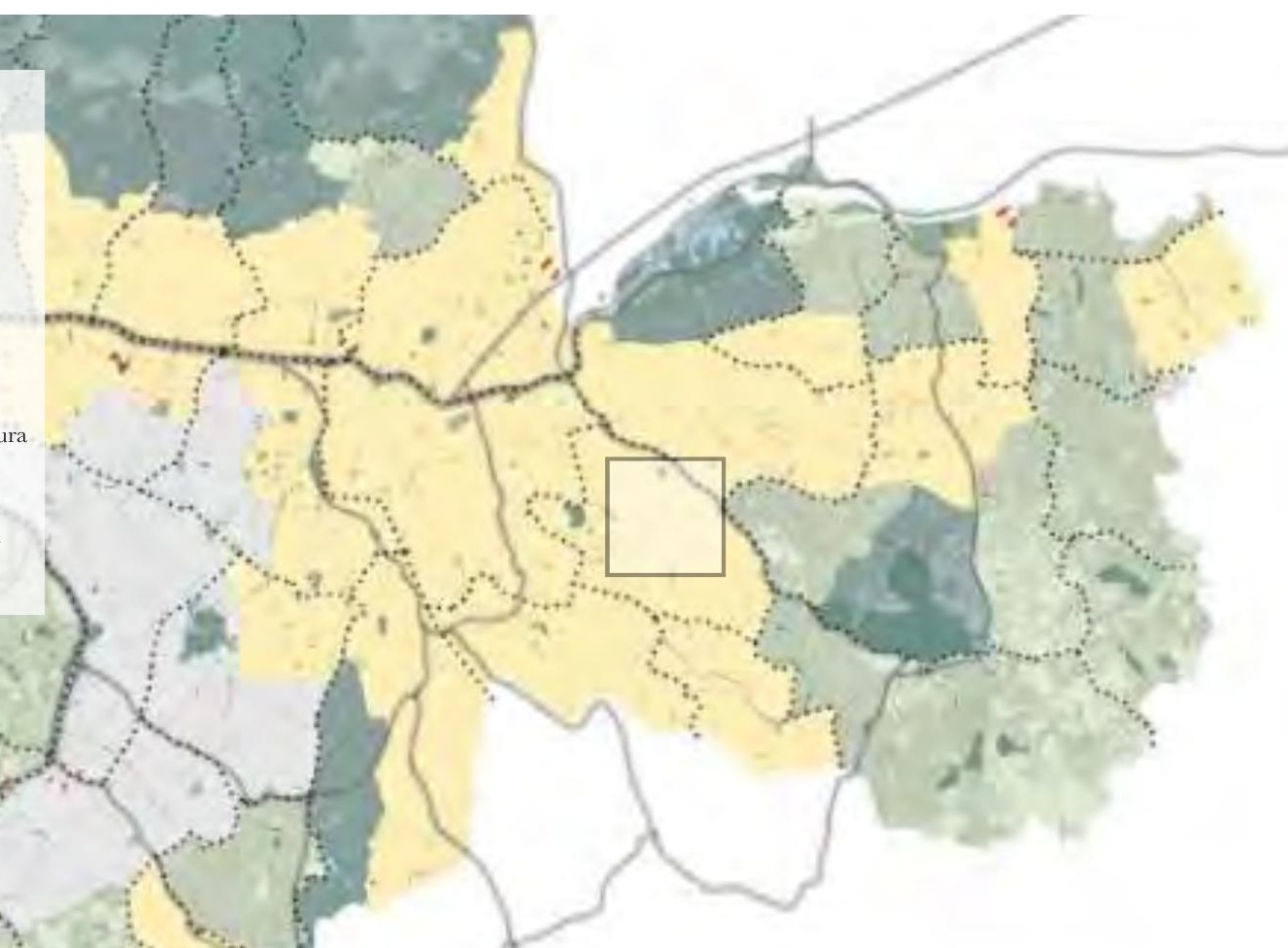


de uma trilha ambiental autoguiada de aproximadamente 1,5 km de percurso que teve como intuito incentivar o uso das áreas verdes do cemitério ${ }^{108}$. Assim, devido a associação de áreas verdes ao lazer e recreação, o Vila Formosa acaba se configurando como um espaço atraente e acessível à população do entorno, que o utiliza para realização de atividades deste gênero de forma paralela à rotina do cemitério. Nesse sentido, alguns moradores da região colocam que "o cemitério é como o quintal que eles não têm em casa"

Assim, percebe-se que o local demonstra uma cotidianidade não apenas em relação às atividades esperadas e inesperadas, mas também a respeito de práticas reticentes que encontram no cemitério campo para sua realização. Desse modo, se à primeira vista os cemitérios podem ser vistos de forma tétrica e monofuncional, o Vila Formosa se mostra um espaço bastante dinâmico, apresentando-se como um campo fértil a diversas formas de atuação e percepção. A partir delas é possível não apenas imaginar as características do lugar que levam à sua realização, como também discutir como elas podem influenciar na designação do cemitério.
108 Cf. em "Trilha

ambiental autoguiada é inaugurada no

Cemitério da

Vila Formosa".

Disponível em <www. prefeitura.sp.gov.br/ cidade/secretarias/ subprefeituras/ aricanduva/noticias/ index.php?p=59648> Acesso em: 7 jul. 2017.

109 Conforme incursão etnográfica realizada no Cemitério da Vila Formosa, julho de 2017.

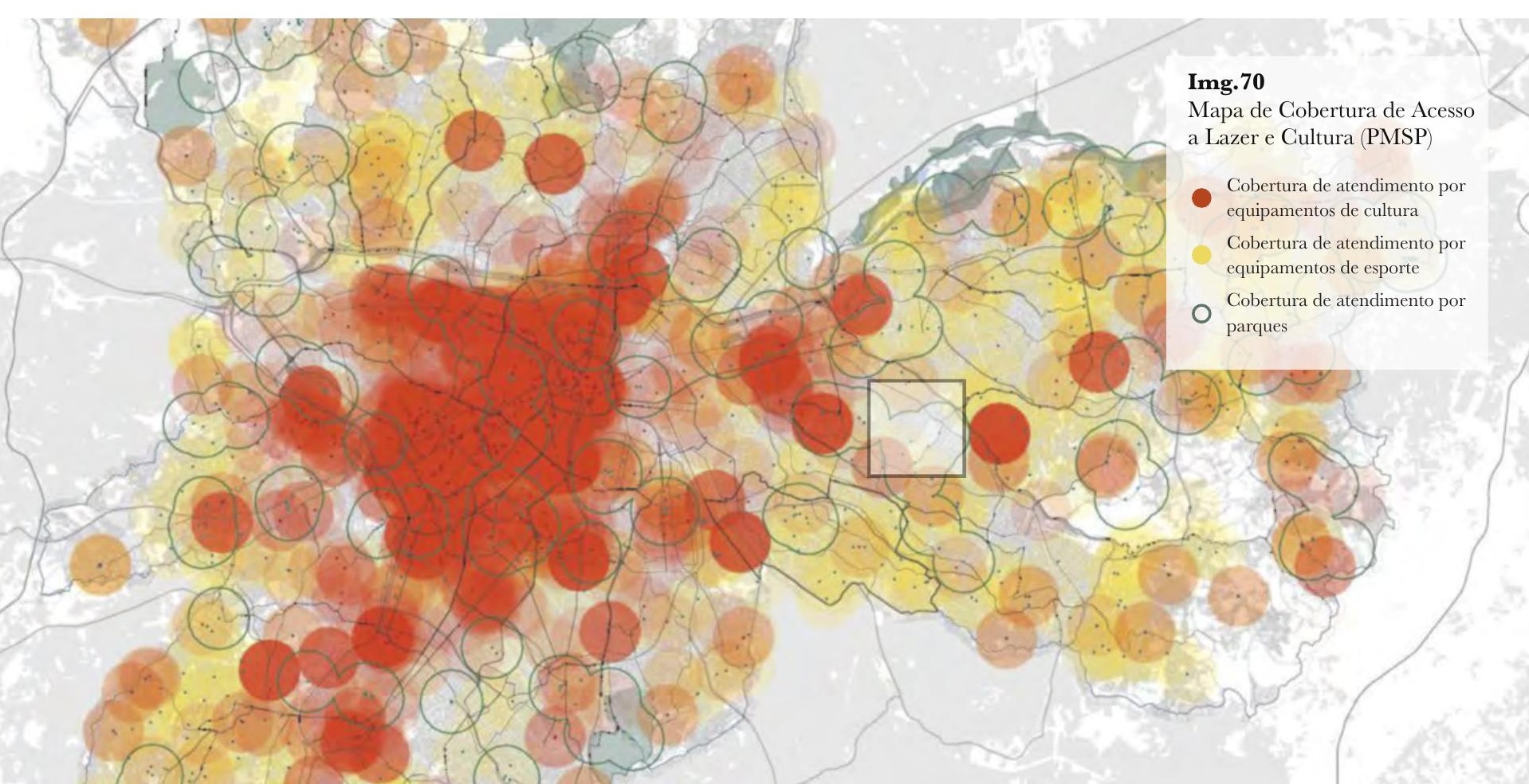




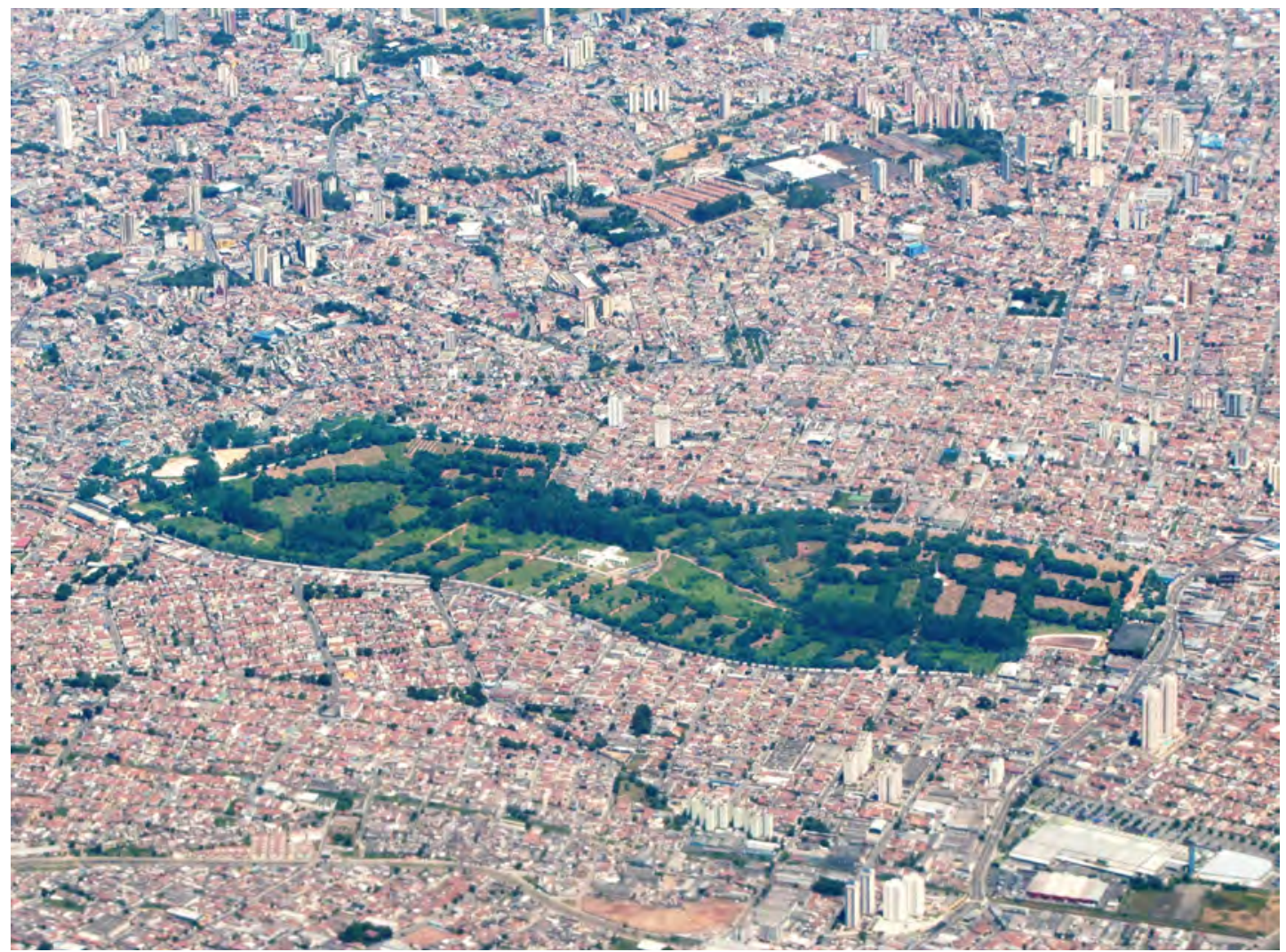

Img.71 Cemitério da Vila Formosa, vista voo de passáro (mapio.net, com edição do autor) 


\section{Possibilidades}

\section{$\underline{\text { Indicadores }}$}

A expansão de São Paulo e a decorrente absorção dos cemitérios pela malha urbana levou ao surgimento de diversas propostas de utilização da área do Vila Formosa. Eduardo Rezende (2000) descreve uma dessas investidas, apresentada pelo então vereador Gabriel Martins Ortega, em 1986. Sua ideia era usar parte da área do cemitério para construir conjuntos habitacionais que, segundo o vereador, poderiam abrigar até 500 mil pessoas. A proposta previa a transferência dos restos mortais para um cemitério vertical a ser construído em lugar a ser definido, também na zona leste de São Paulo. Apelidada à época de Projeto Poltergeist, a ideia não foi para frente por ser considerada polêmica. Desse modo, percebe-se que da mesma forma que há um movimento para se pensar a respeito do uso das áreas de cemitério, também há um receio em lidar com assuntos e espaços atrelados à morte. Ainda assim, observa-se que partes do cemitério já foram concedidas para outros usos, como em 2008 quando a área de mais de $10 \mathrm{mil} \mathrm{m}^{2}$ que abrigava o antigo velório foi usada para dar lugar a um reservatório tipo piscinão, construído para minimizar o impacto das chuvas na região da bacia do Aricanduva. 
Também buscando ponderar sobre o uso das áreas do Vila Formosa, conforme visto no tópico (7) Cemitérios de São Paulo, nota-se que em 2016 o Plano Diretor manifestou a intenção de pensar o local como um parque. Nota-se que a iniciativa do Plano Diretor representa uma abordagem distinta dos exemplos anteriores, no entanto, dada a abrangência de acepções e

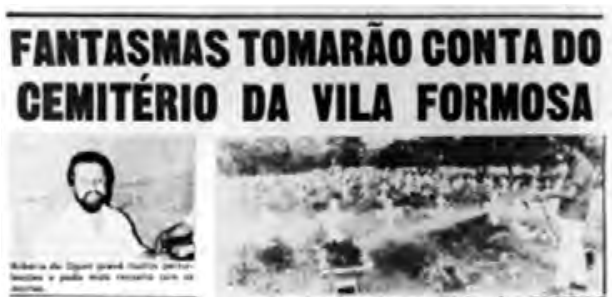

Img.72 Reportagem na Folha de S.Paulo em 7 de julho de 1986 de manifestação contra o "Projeto Poltergeist" (folhapress) formas referentes ao termo parque, caberia pensar que tipo de parque se está imaginando. Se, como proposto pelo Serviço Funerário, esses locais seriam "parques de memória" (SFMSP e FUNDASP, 2016, p.9), resta desenvolver o conceito e o significado almejados para esses lugares. Qual seria, por exemplo, a diferença entre parque de memórias e parque memorial? Sabendo que o conceito de memória, apesar de ter uma relação fundamental com a morte, perpassa essa temática, onde entraria a noção de cemitério?

Como a ideia colocada pelo Plano Diretor é bastante incipiente e carece de maiores detalhamentos ${ }^{110}$, torna-se inviável uma análise mais específica sobre essa concepção. A ideia de transformar o local em parque pode tanto indicar um caminho de maior integração do espaço com seu entorno, como também a sua utilização para uma atividade urbana sem relação com a temática da morte. Por mais que possa parecer propício pensar que o cemitério se converta em um parque urbano no lugar de um complexo habitacional, é essencial desenvolver perspectivas que considerem a condição do Vila Formosa como o espaço fúnebre fundamental que ele é, e não apenas como um terreno urbano desprovido de atributos e referências prévias. Desse modo, a partir das tentativas de intercessão no lugar, nota-se que a desconsideração da temática fúnebre representa um caminho insolente, enquanto que a consideração das características inerentes ao local pode apresentar alternativas mais promissoras em relação a como a sociedade entende esse lugar. Desse modo, salienta-se que é fundamental imaginar as formas pela qual o espaço do Vila Formosa pode manter-se como um cemitério, porém aberto à percepções e apropriações diversas que podem ampliar a abrangência de uso do local.

110 O tema foi levantado tanto em conversa com Lúcia Salles, superintendente do Serviço Funerário à época, como em conversa com Helia Pereira, arquiteta do Departamento de Planejamento Ambiental (DEPLAN) da Secretaria do Verde e Meio Ambiente (SVMA). Em ambos os casos, a ideia foi colocada como uma intenção, sem maiores definições. 
Nesse sentido, as ideias de espaço polissêmico, paradoxal e limiar podem contribuir para imaginar formas de atuação no espaço direcionadas às possibilidades de encontro induzidas pela morfologia do espaço e pelos atributos próprios do lugar. Essa ideia é desenvolvida pelos arquitetos Bernardo Secchi e Paola Viganò no livro La ville poreuse (2012), onde os autores desenvolvem os conceitos de poro, permeabilidades e porosidade. Para Secchi e Viganò, os poros representam os pontos onde as possibilidades estão abertas, ou seja, onde é possível haver movimentos e interações. Quanto à permeabilidade, ela representa a facilidade ou dificuldade de acesso dessas possibilidades. Assim, a partir das noções de poros e de permeabilidade, a porosidade pode ser entendida como a razão entre o volume de poros e o volume total, ou seja, a relação entre possibilidades que conseguem "passar" e a resistência a elas. Desse modo, é possível desenvolver capacidades de diálogo e de ligação, aproveitando eventuais oportunidades para a reestruturação de situações de convívio e de consonância nos espaços através de possíveis conexões entre os seus poros.

No caso do Vila Formosa, as porosidades e possibilidades de se estabelecer conexões passam justamente pelo desenrolar da multiplicidade de questões que ele apresenta: espacial, ambiental, cultural, social, memorial e afetiva. Esses aspectos podem ser entendidos como interstícios capazes de estabelecer vínculos entre a cidade, os espaços e as pessoas. Todas essas instâncias são fundamentais, sendo o principal desafio encontrar formas de equilíbrio entre elas, sem que uma se sobreponha à outra. Trata-se, pois, de experimentar as articulações viáveis, desenvolver proximidades e convivências adequadas para a situação.

Para tal, imaginou-se duas formas de pensar o lugar, uma baseada na ideia de conjunção e outra de aproximação. A conjunção ajuda a pensar nas questões relativas à morte e seus espaços dentro de um entendimento coletivo, mas que tenha em mente a importância íntima dessa relação, das partes que formam o conjunto. Já as aproximações têm como intuito discutir sobre aspectos mais palpáveis, trabalhar com os elementos que o espaço oferece ou poderia oferecer através da diversidade, da profusão. Entende-se que essas duas formas de pensar são complementares e, portanto, indissociáveis. Para melhor entender a relação que se pretende estabelecer, é possível aproveitar-se da imagem da árvore, onde o tronco exprime uma direção conjunta até o momento em que as ramificações caminham por diversos sentidos, aproximando-se de tópicos mais pontuais para encontrar formas de estabilidade. As conjunções estão, então, ligadas às questões mais estruturais, enquanto que as aproximações podem ser associadas aos aspectos mais conjunturais. 


\section{Gonjunções}

Tratando-se de um lugar relacionado à morte e à memória, é fundamental ter em mente as marcas que o Vila Formosa carrega. Nesse sentido, descobriu$\mathrm{se}^{111}$ que próximo à entrada sul do cemitério (Vila Formosa I) havia uma vala clandestina criada durante o governo militar no Brasil (1964-1985) para ocultar os cadáveres de perseguidos por este regime. Assim, para além de uma discussão sobre o direito ao lugar e às representações da morte, o Vila Formosa é um espaço chave para se compreender a ausência também sob a perspectiva do trauma. Dessa forma, ao se pensar nesse local, é necessário encarar as dificuldades que o trauma representa, definindo uma nova posição para ele, uma que simboliza um processo natural de mudanças, como coloca a arquiteta e urbanista Tali Hatuka (2017). No caso dos desaparecimentos políticos, os familiares e amigos são desprovidos do processo fundamental de lidar com a morte, não encontrando lugar-símbolo para ela devido às dúvidas e incertezas sobre o destino das pessoas em questão. Com isso, essas pessoas ficam em um estado de suspensão, privados do luto, em uma constante busca de respostas dificeis de se conseguir.

Essa sensação é bem representada em Nostalgia da $L u z^{112}$, filme do cineasta chileno Patricio Guzmán. Utilizando o deserto do Atacama como cenário, Guzmán traçou um

A vala foi descoberta em 2010, paralelo entre o trabalho local de astrônomos, através de expedição conduzida por representantes do MPF-

SP, da Comissão Especial sobre Mortos e Desaparecidos Políticos (CEMDP), do Instituto Nacional de Criminalística do Departamento de Polícia Federal

(INC/DPF) e do IML-SP. em busca de vida extraterrestre, e a procura incessante de familiares de desaparecidos durante a ditadura militar chilena (1973-1990) pelos restos mortais de seus entes queridos, enterrados em algum lugar do deserto. $\mathrm{O}$ filme permite que a ausência dessas pessoas possa ser percebida como um problema de todos os cidadãos envolvidos com o lugar e o momento histórico em questão, e não somente dos familiares envolvidos, funcionando como meio para se encarar o trauma. 
Pensando essa questão sob a ótica do cemitério, ao traçar um paralelo entre o filme e uma abordagem espacial, é possível refletir sobre como o trauma poderia ser enfrentado neste segundo caso. Para se pensar nessa perspectiva, é preciso lembrar o papel simbólico que lugares como o cemitério podem exercer através dos significados que são dados a eles, fundamentais não apenas para aqueles que têm seus entes queridos enterrados no local, mas para a própria memória da cidade. Como visto até aqui, os cemitérios assumem um lugar de referência para o relacionamento entre os vivos e os mortos, marcado pela presença difusa daqueles que se foram, seus rastros. Espaços como o Vila Formosa abrigam histórias e trajetórias importantes que, como tal, devem ser transmitidos como parte inerente de suas próprias identidades, fortalecendo um senso de acolhimento e consideração. Dessa forma, como coloca $\operatorname{Dolff}(2014$, p.70), o lugar se torna ao mesmo tempo "o portador e o gatilho da memória", sendo a memória não apenas uma recordação, mas uma "faculdade mental", de acordo com o contexto que se encontra. Com isso, podemos nos tornar testemunhas tanto dos acontecimentos históricos, quanto das experiências relacionadas ao lugar.

Nesse sentido, há que se considerar uma mudança 113 significativa nas formas de abordar a morte, trazida pelo século $\mathrm{XX}$, que representou uma mudança nas atitudes públicas em relação ao corpo após a morte. As grandes guerras do período abalaram a ideia de ressuscitação, que sofreu um duro golpe devido às centenas de milhares de corpos que desapareceram, foram largados ou enterrados ao acaso (WORPOLE, 2003). Assim, o apego à sepultura individual como o local simbólico da identidade foi deteriorado, dando lugar ao papel simbólico de instâncias compartilhadas, como os Túmulos do Soldado Desconhecido ${ }^{113}$.

Nesse sentido, Hatuka (2017) defende que, ao se pensar nos espaços de trauma, é preciso ter cuidado para que as cidades não sejam dominadas por lugares do que a autora chama de uma ausência urbana. Para tal, a arquiteta reitera a diferença entre perda e ausência, buscando a melhor forma de se tecer uma relação operante com o lugar:

Túmulo do soldado desconhecido é o nome que recebem os monumentos feitos em homenagem aos soldados que morreram em tempos de guerra sem que os seus corpos tenham sido identificados. Em muitos casos eles são cenotáfios, embora alguns contenham os restos mortais de alguns dos soldados mortos durante o conflito. 
"A perda é particular, imediata e se relaciona com um tempo e um acontecimento específicos, enquanto a ausência é trans-histórica, mítica e se intensifica ao longo do tempo. Quando um trauma é aceito como perda, o contexto urbano (como em ambientes de pós-guerra) pode ser abordado de diversas maneiras, como, por exemplo, melhorando as condições da situação estrutural-social básica da cidade. Se o trauma é percebido como ausência, a urbanidade torna-se um problema sociopolítico; uma busca interminável pelos habitantes por um retorno a um senso de unidade tanto do lugar como da comunidade. Essa situação trivializa ou até mesmo elimina as práticas cotidianas no local do trauma e, portanto, simplifica a história passada e em andamento do lugar. Essa eliminação suspende o presente (práticas cotidianas) e o futuro (intervenções ou planos para modificar o lugar), fundindo o momento (do trauma) com o significado do lugar. Essa suspensão é uma ausência urbana."

(HATUKA, 2017, p.55-56)

A partir do ponto de vista de Hatuka, torna-se importante salientar a importância da realização de intervenções junto aos espaços de memória traumática, conforme realizado em 2016, através de dois memoriais instalados no cemitério em homenagem aos desaparecidos durante a ditadura militar ocultados no Cemitério da Vila Formosa. O primeiro deles é composto por um pequeno caminho ajardinado com 22 placas de madeira cravadas no solo, cada uma indicando um dos anos de vigência do período ditatorial. Já o outro, é composto por uma laje de concreto onde estão dispostas 10 toras de madeira simbolizando os 10 desaparecidos políticos sepultados clandestinamente no local ${ }^{114}$. Assim, ao trazer à tona questões como o descaso e desrespeito com os dissidentes do regime militar, os memoriais atuam como um lembrete dos acontecimentos traumáticos ocorridos. Como kolossós ${ }^{115}$, eles são capazes de trazer à superfície fatos da história, revelando um potencial didático e permitindo uma reflexão crítica sobre os acontecimentos passados. Ainda que pouco difundidas, iniciativas como esta são bastante significativas, principalmente num contexto onde os eventos históricos e memoriais tornam-se alvo de uma disputa ideológica.

114 Cf. Luto e Memória da ditadura: O Memorial dos Desaparecidos de Vila Formosa, em São Paulo. Janaína de Almeida Teles, 2017.

115 O conceito de kolossós foi desenvolvido no tópico (8) Morte, Ausência, Semiótica. 

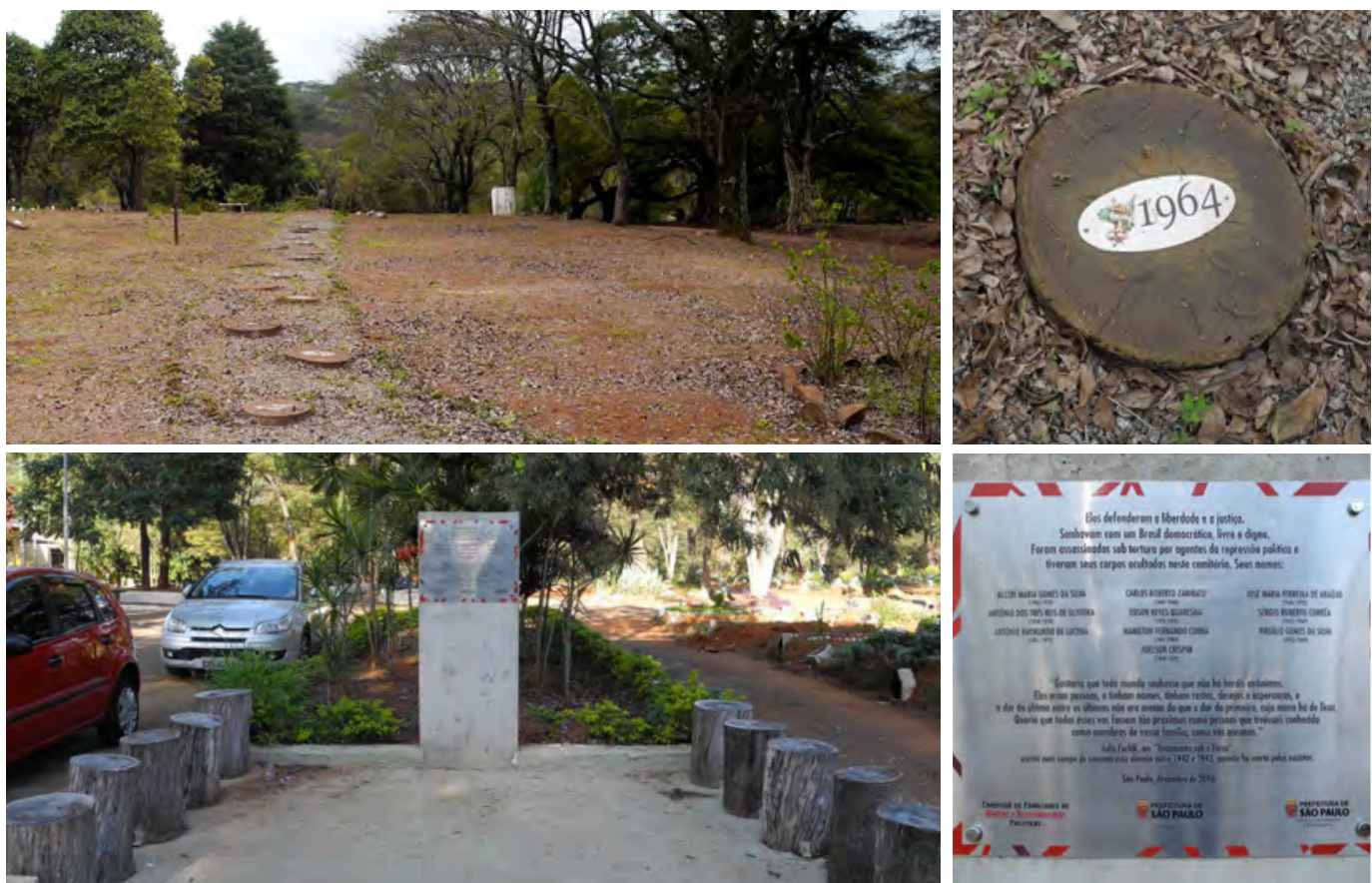

Img.73 a 76 Memoriais em Homenagem aos Desaparecidos na Ditadura Militar do Cemitério da Vila Formosa (fotos do autor)

Desse modo, nota-se que este evento traumático, parte da história do cemitério, pode incitar novas perspectivas de configuração do espaço, de forma a reverberar sua memória junto à população local. A partir dele, é possível avistar fatos significativos à construção social do lugar, relacionados com a importância material representada pelo reconhecimento dos seus rastros. Voltando essa questão para uma perspectiva mais urbana, é possível recorrer novamente a Hatuka (2017) que ressalta a importância de fortalecer a ideia de vivência nesses espaços como forma de evitar que a ausência decorra em uma paralisia. Para tal, ao resgatar um lugar de memória problemática, o acontecimento histórico deve ser utilizado como ponto de referência para repensar o lugar de maneiras novas. Para ela, "longe de constituir um apagamento, isso envolve re-imaginar o futuro do lugar" (HATUKA, 2017, p.56). 
Ainda, tendo como base esse contexto, é possível refletir sobre algumas questões referentes à ideia de representação compartilhada da morte. É possível pensar em instâncias que carreguem a ideia de conjunção não apenas em eventos traumáticos, mas a partir de uma noção partilhada da morte. A esse respeito, é possível levantar alguns questionamentos. Como proceder com o ritual de indivíduos que são contrários à formalização e individualização da morte? Se a formalização compartilhada não passa mais pelos dogmas religiosos, em que elementos ela pode se basear? Na falta de um consenso sobre como representar a morte, ela poderia se tornar o suporte de uma formalização dinâmica, capaz de esboçar caminhos para uma futura cultura funerária?

Pensando nesse aspecto a partir da ótica da dimensão populacional de uma cidade como São Paulo, pode-se discutir sobre meios de se buscar uma maior paridade social frente à morte, tendo em vista os distintos cenários e condições existentes de acordo com a condição socioeconômica do indivíduo em questão ${ }^{116}$. Ao ampliar as formas de tratamento do cadáver de modo a compreender a ideia de difusão do nesse sentido, cabe uma reflexão sobre a condição de equiparação não apenas num sentido geracional, mas também histórico, pois a grande maioria das pessoas que já viveu no planeta é anônima para a história e quase a totalidade delas não tem seu lugar demarcado. corpo no espaço, é possível imaginar dispositivos de memória e de expressão compartilhados inscritos nos cemitérios. A noção de associação pode assumir um papel representativo através de imagens e duplos comuns, lugares e pontos de apoio materiais que podem ser compartilhados através da ideia de conjunção. Nestes locais, a noção de uso comum e disperso do espaço assume um papel preponderante frente à demarcação e distinção do lote de enterro.

Efetivamente, espaços fúnebres compartilhados podem ser encontrados em diversos cemitérios, normalmente na forma de jardins de memória ou espaços cinerários. Os próprios cruzeiros existentes no Vila Formosa assumem, de certa maneira, este papel compartilhado, neste caso não no sentido de difusão dos restos mortais, mas como marco para colocação de velas e homenagens aos entes queridos falecidos. 
Ainda, nota-se que espaços e meios fúnebres compartilhados têm sido cada vez mais encontrados em outras situações. Alguns exemplos são a opção de torcedores de futebol que optam por direcionar as cinzas aos estádios e memoriais do seu clube de coração ${ }^{117}$, as propostas trazidas pelo DeathLAB, ou ainda no próprio movimento de sítios de enterro natural, que enxerga no retorna à natureza uma identidade junto ao meio natural. Davies King (1998, p.216, tradução nossa), ao falar sobre o tema coloca que: "embora os envolvidos expressem diferentes sentidos no significado dos símbolos comemorativos, refletindo suas diferenças de percepção, eles mantêm um senso de unidade suficiente na recordação dos mortos de modo a marcar um hábito público coletivo".

Para tal, é fundamental pensar nas qualidades desses 117 espaços, de modo a oferecer lugares que valorizem os aspectos essenciais que a morte demanda. É possível, por exemplo, imaginar que elas possam ser adotadas nos diversos cemitérios da cidade, de modo a permitir alternativas àqueles que eventualmente prefiram este tipo de conjunção. Os sistemas que não consideram as sensibilidades e temporalidades, como a rotatividade e a exumação em três anos, poderiam, então, ser modificados para se adequar a formas mais suaves, respeitando parâmetros que vão além de questões utilitárias. A ideia de rotatividade pode se aproximar de uma noção de transição, algo pensado de forma gradativa e adequada à complexidade que o tema demanda. A alternância do espaço de cemitério pode se adequar a essas nuances, facilitando a criação de ambiências e percepções que busquem representar esse processo. Nesse sentido, o Cemitério Valle Armea, em Sanremo, pode ser usado como referência de espaço que carrega uma lógica de uma passagem mais delicada, condizente tanto com aspectos funcionais, como também afetivos e sentimentais. Desse modo, é possível pensar em forma de a composição espacial do cemitério favorecer uma maior receptividade aos temas afetivos, trazendo para o lugar a ideia de uma trajetória processual. 
Ainda sobre a diversificação dos dispositivos fúnebres, a pluralização das práticas e tratamentos do cadáver e a capacidade do corpo em assumir diferentes formas permitem pensar novas alternativas para ampliar os meios de se relacionar com o corpo no espaço. Existem hábitos e formas diferentes para os lugares da vida, não há porque não haver o mesmo para a morte, ampliando os limites da situação vigente. Com isso, é possível que cada pessoa encontre sua singularidade em outras formas além da ideia da sepultura individual. Nesse sentido, é preciso reforçar a diferença entre ideias que podem ser vistas como universais e ideias universalizantes, conforme discutido anteriormente na análise das propostas baseadas em células químicas memoriais. A pluralização busca universalizar, permitir a abrangência de opções para o tratamento da morte e favorecer as escolhas. Já o universalizante tende a limitar a variedade através da predominância de uma ideia global.

Portanto, em um espaço amplo e rico de ambiências como o Vila Formosa, é possível vislumbrar uma série de possibilidades que poderiam ser experimentadas. O cemitério possui grandes áreas abertas e gramadas, áreas de bosque com árvores altas, é atravessado por um córrego, tem limites voltados tanto a áreas residenciais, como à avenida João XXIII, que possui comércios, serviços e corredor de ônibus, enfim, o Vila Formosa oferece uma variedade de situações. Assim, mesmo sem grandes intervenções no espaço, é possível vislumbrar o usufruto desses espaços a partir de uma maior pluralização dos tratamentos do cadáver e da sua correspondente forma de relação com as ideias da memória, religiosidade e luto. Também nesse sentido, é possível que formas coletivas encontrem lugar, sendo representadas de formas mais abrangente, como no caso do Skogskyrkogården, onde além das sepulturas, os bosques assumem um papel simbólico comum de representação fúnebre. Para tal, é preciso aproximar um pouco do ambiente do Vila Formosa, de modo a imaginar possibilidades mais pontuais de atuação neste lugar. 


\section{Aproximações}

Além da consideração de outras formas de orientação para a composição do espaço cemiterial, é possível considerar que seus elementos também podem representar e simbolizar aspectos sensíveis da relação com a morte, buscando reforçar o sentido de articulação e conexão entre as pessoas e os espaços fúnebres. Para tal, é importante ressaltar que isso não significa buscar por soluções complexas e elaboradas, sendo possível encontrar formas de representação e interação a partir de gestos e ideias simples.

Worpole (2003), por exemplo, destaca o trabalho feito pelo artista e cineasta Derek Jarman na composição dos jardins da igreja de Gamla Uppsala, na Suécia. Usando como referência os jardins zen japoneses, Jarman imaginou os túmulos cobertos por uma fina camada de cascalho de granito onde os visitantes podem desenhar padrões simples, remodelando as sepulturas regularmente. Assim, através de um simples movimento, são estabelecidas novas formas de interação entre os visitantes e os locais de enterro de modo a abarcar tanto aspectos gerais do ambiente, como as singularidades de cada história. Jarman consegue oferecer um elo entre um jardim íntimo e o espaço público, demonstrando como é possível gerar novas possibilidades através de combinações e associações elementares. Assim, pode-se imaginar novas formas de criar cenários memoriais e outras paisagens que respondam com sensibilidade tanto às questões de esfera íntima como da memória pública. Nesse aspecto, reforça-se que, além da importância de trabalhar as instâncias pessoais decorrentes do trato com a morte, os espaços comuns podem ajudar a lidar com a dor e a ausência ao possibilitar a exteriorização dos sentimentos. A expressão pública tem seu papel no processo de luto e no reconhecimento do compartilhamento da memória. Jarman soube reconhecer esse aspecto ao possibilitar a intervenção dos visitantes junto aos túmulos de seus entes queridos.

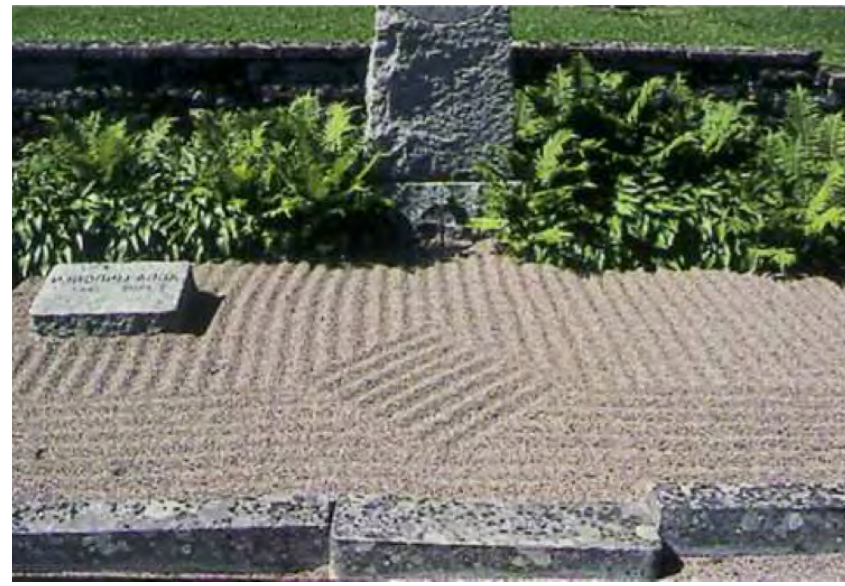

Img.77 Túmulos em Gamla Uppsala (foto Howard Sooley) 
Pensando na configuração dos elementos constituintes do Cemitério da Vila Formosa com esse olhar, os muros se apresentam como um dos seus elementos mais significativos, sendo determinantes para a forma de encontro entre o cemitério e a cidade. De forma geral, a presença de muros nos cemitérios pode ser entendida tanto de forma simbólica como utilitária. No primeiro sentido, existe uma compreensão da necessidade de criação de limites entre o universo dos vivos e dos mortos. A partir dessa lógica, surgem diversas interpretações, desde as mais cautelosas, que veem necessidade de se delimitar o local de trânsito das almas, até as mais lenientes, como a ideia de resguardo e preservação do descanso eterno. Já pelo lado utilitário, tem-se a preocupação com medidas mais práticas, como a possível invasão de animais ou, no caso de cemitério tradicionais, o roubo de esculturas e outros materiais valiosos. No entanto, justificativas à parte, em um viés físico-espacial, o muro acaba por instituir uma separação entre os domínios do cemitério e da cidade. Em São Paulo, a maior parte dos muros dos cemitérios foi construída de forma maciça, tendo ao menos 2,20m de altura (PMSP, 1932). Desse modo, ao circular pela cidade, é comum encontrar altos e espessos muros brancos que cercam os cemitérios municipais.

No Vila Formosa os muros seguem essas características, todavia, apresentam uma peculiaridade: boa parte deles foi associada aos ossários, ou seja, a mesma massa construída face à cidade é muro, e face ao cemitério, é ossário. Assim, ao determinar que a linha de encontro entre a cidade e o cemitério é uma parede com ossos, estabelece-se uma situação um tanto quanto pitoresca, já que os mortos ajudam, materialmente, a constituir uma separação. Por outro lado, em uma tentativa de pensar uma cidade mais fluída, é possível imaginar um cenário ideal onde vivos e mortos não precisam de um elemento divisor tão rigoroso, podendo compartilhar o espaço urbano de forma contínua. No entanto, mesmo em um cenário onde se acredita necessária uma divisão, é possível imaginar uma maior permeabilidade. Essa condição poderia ser obtida através do uso de grades ou, ainda, pela realização de aberturas que deem maior visibilidade aos espaços do cemitério. Para isso, poderia se considerar trechos significativos, como os pontos de ônibus existentes na Avenida João XXIII. Gestos nesse sentido podem servir como convite à interação, sendo capazes de estimular novas formas de se relacionar com o cemitério. Eles ajudam a desconstruir a ideia de uma fronteira rígida, colocando a possibilidade de se vivenciar esse limite, de ocupá-lo por meio de elementos que podem ser construídos para tal. 
Já os ossários, segundo Auzelle (1965), são o elemento mais importante do cemitério, pois eles permitem a rotação das concessões e a continuidade do ciclo de enterros. Ao contrário do mundo subterrâneo dos enterros, a presença dos mortos nos ossários se dá no ar, envolvendo frontalmente os frequentadores do cemitério. No Vila Formosa, eles constituem um dos elementos arquitetônicos mais significativos, contudo, percebe-se que não há maiores preocupações tanto com sua qualidade construtiva, como com sua disposição e, principalmente, sua manutenção. Em alguns casos, as paredes de ossários foram feitas muito próximas umas das outras, criando ambientes estreitos e pouco acolhedores. Essa configuração favorece sua apropriação para atividades ilícitas, o que demonstra que os ossários são utilizados como esconderijo tanto quanto espaço fúnebre. É bastante comum encontrar sinais de consumo de drogas ou até resíduos humanos nestes locais. Por outro lado, devido ao funcionamento do cemitério bastante atrelado à necessidade de espaços de ossários, é possível imaginar que esses elementos poderiam desempenhar um papel ainda mais marcante no cemitério. Por sua natureza conjunta, em contraposição às sepulturas, os espaços de ossários poderiam ser desenhados como estruturas coletivas também no sentido de favorecer uma convergência entre os visitantes, como espaços de troca.

O Cemitério de Igualada oferece alternativas perspicazes nesse sentido. Diferente do Vila Formosa, onde os nichos foram pensados apenas para colocação dos ossos, no Igualada a estrutura de lóculos foi objeto de um desenho cuidadoso que permite a colocação de objetos afetivos e recordações trazidas pelos visitantes. Em relação aos espaços onde ficam essas estruturas, percebe-se uma preocupação em configurar ambientes que favoreçam a presença e a conexão com o lugar. Os elementos que compõem o lugar seguem esse pensamento. A presença de árvores, o desenho de piso, a colocação de bancos e as fontes de luz ajudam a criar uma ambiência propícia à meditação e o estar.

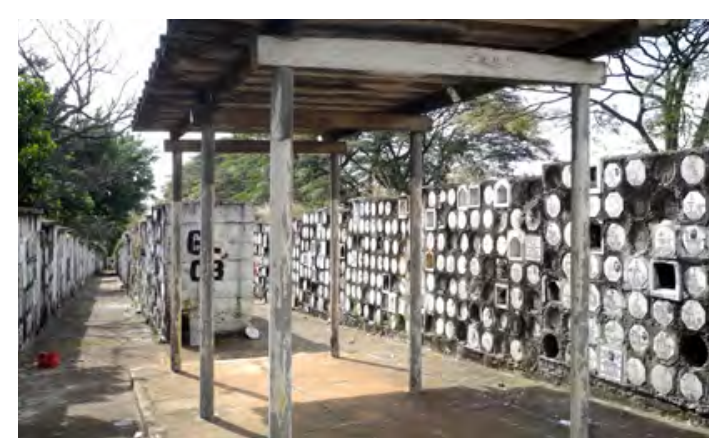

Img.78 Trecho de ossário e (também) muro do cemitério (foto do autor)

Percebe-se como no Vila Formosa o uso desses e outros elementos que podem dar qualidade ao espaço foram pouco trabalhados, sendo muito mais frutos de uma lógica funcional de sepultamento do que de criação de um lugar paisagisticamente trabalhado. As vias são, em grande parte, de terra, o que em dias de chuva 
representa um problema para a circulação. Mesmo nos trechos de piso mineral, foi dada preferência ao asfaltamento, que atualmente se encontra em péssimo estado de conservação. Ainda, nota-se que o próprio traçado das quadras foi pensado muito mais numa lógica de distribuição dos lotes de enterro e de fluxos passageiros do que para a criação de espaços ou ambiências de estar. Iluminação, bancos, lixeiras e outros mobiliários são praticamente inexistentes. Um dos poucos elementos que o espaço oferece são as torneiras d'água usadas pelos jardineiros para o cuidado das campas. Ainda assim, a presença determinante de vegetação do lugar é capaz de oferecer um ambiente marcante na paisagem do município. Nesse sentido, uma aproximação deste local à Secretaria do Verde e Meio Ambiente (SVMA) pode ajudar a estabelecer o Vila Formosa como espaço de referência regional, trazendo a ideia de se realizar projeto paisagístico também aos cemitérios municipais, que só tem a ganhar com essa associação. Olhando para o exemplo do Cemitério de Igualada ou, ainda, de outros cemitérios como o Skogskyrkogården, percebe-se como a preocupação com a distribuição dos espaços e a incorporação de elementos que ajudam a compor sua ambiência são fundamentais na percepção do espaço de cemitério.

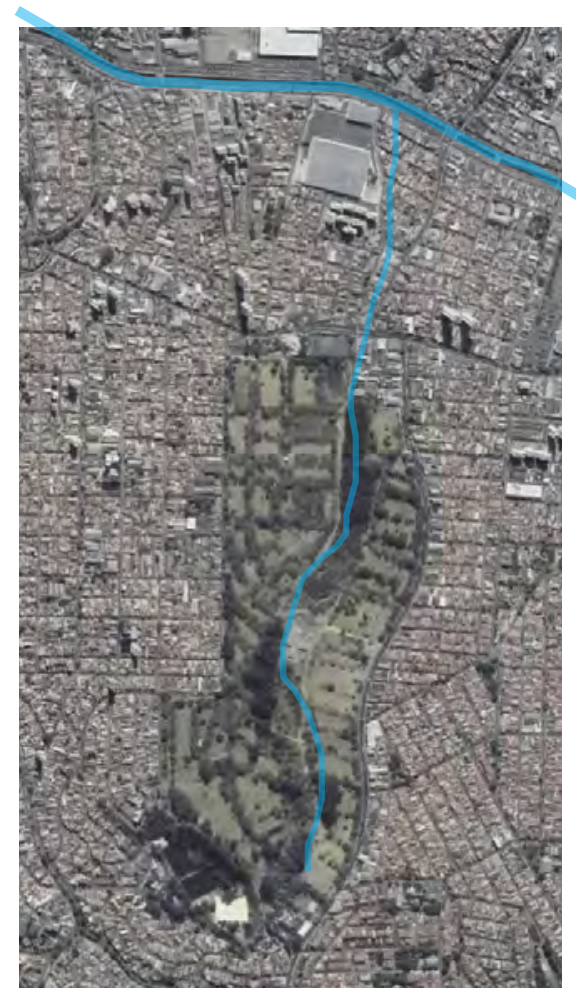

Img.79 Córrego Água Rasa e Rio Aricanduva (imagem google earth, traçado MDC, montagem feita pelo autor do autor)

Ao imaginar a confluência de questões espaciais junto à conjuntura do Vila Formosa, também é possível imaginar o usufruto de questões que o local já oferece. Ele é atravessado, em seu sentido longitudinal, pelo Córrego Água Rasa, que deságua no Rio Aricanduva, a aproximadamente um quilometro do cemitério. A presença do córrego implica a não utilização dos espaços marginais para enterro, de modo a evitar a contaminação das águas pelo necrochorume produzido durante a decomposição. A porção central do cemitério se torna então uma área que pode ser pensada de modo a favorecer outras formas de apropriação. Neste caso, a ideia de percurso trazida pelo Cemitério de Courtrai, permite imaginar possibilidades de reestruturação do cemitério a partir do estabelecimento de uma trajetória, do caminhar. 


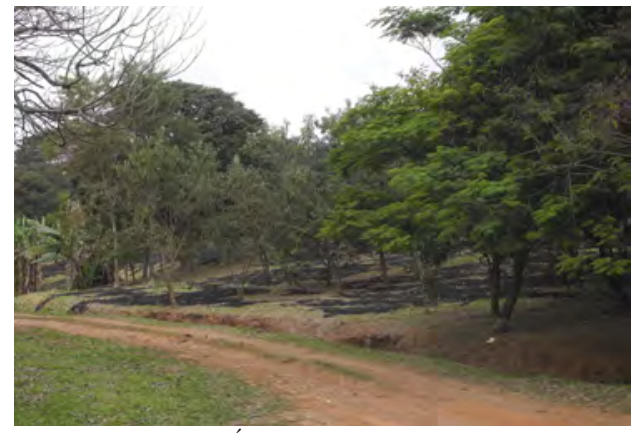

Img.80 Córrego Água Rasa na parte central do cemitério (foto do autor)
Atualmente, a porção central do Vila Formosa se configura como um espaço esquecido. Os trabalhadores do local costumam inclusive sugerir que se evite passar por ali sozinho, por ser um dos pontos de incidência de assaltos devido ao baixo movimento. No entanto, em termos de usufruto do espaço, este local pode representar um dos pontos mais significativos do cemitério. Junto ao córrego, é possível

considerar a constituição de caminhos de pedestres e de ciclistas que tirem proveito da presença d'água e perpassem o espaço do Vila Formosa. Ao ser colocado em evidência, o Água Rasa poderia funcionar com um eixo estruturador dos demais ambientes do cemitério, um meio frutífero para se organizar os espaços e atmosferas que o percurso pelo cemitério pode propiciar.

Ainda tendo em mente a ideia de aproximações eventuais, é possível se voltar a uma reflexão sobre as diferentes formas de uso dos espaços de cemitério. Outro ambiente fúnebre de São Paulo pode servir como referência neste caso: o Cemitério de Colônia. Localizado em Parelheiros, a necessidade e a espontaneidade fizeram com que a antiga casa do coveiro do cemitério fosse reformada para receber livros e atividades culturais, fundando a Biblioteca Comunitária Caminhos da Leitura ${ }^{118}$. Idealizado em 2009, o espaço foi bem recebido pela comunidade local, apresentando uma nova possibilidade de atividades cotidianas paralelas em um espaço fúnebre. É possível imaginar alguns motivos para que essa condição tenha corrido de forma amistosa, como o fato de a leitura e o estudo configurarem atividades que demandam paciência e silêncio, consideradas mais respeitosas com o tema da morte. Tanto os lugares de leitura e estudo como os espaços fúnebres costumam ser relacionadas a ambientes serenos e contemplativos, revelando então uma "correlação" de ambiências. Assim, a partir da experiência do Cemitério de Colônia, é possível imaginar o uso concomitante dos espaços através da ideia de afinidades que cada situação pode oferecer.

118

Conforme reportagem "Cemitério vira espaço de leitura na zona sul de São Paulo", de Priscila Mengue (O Estado de S.Paulo). Disponível em < sao-paulo. estadao.com.br/noticias/ geral,cemiterio-vira-espacode-leitura-na-zona-sul-desao-paulo,70001740686>. Acesso em : 16 jan. 2019. 
Por fim, ao discutir as possibilidades apresentadas tanto pelas pré-existências como pelas potencialidades de um lugar como o Vila Formosa, espera-se suscitar reflexões sobre a forma com que o cemitério e a cidade se encontram. Nesse aspecto, ressalta-se a importância de se experimentar, de se sentir junto à sociedade e à cidade quais desses caminhos convêm ou não seguir. Para tal, reforça-se que essas discussões devem ser consideradas de modo a oferecer espaços onde a morte mantém-se como protagonista, deixando claro que o local é, em sua essência, um espaço fúnebre. Portanto, ao mesmo tempo que o cemitério pode deixar de ser percebido como local estático e impermeável, ele não deve se confundir com um conjunto habitacional, com um parque, ou qualquer outro espaço desprovido de qualidades inerentes aos temas de memória, religiosidade e luto. Nesse sentido, procurouse refletir sobre possibilidades que têm como intuito encontrar as formas de conciliar aspectos da morte e da vida de forma complementar e concomitante. Portanto, ao buscar realizar um exercício reflexivo sobre esses lugares, imaginam-se caminhos onde o cemitério é capaz de abrigar os variados aspectos que envolvem tanto o espaço fúnebre, como o meio urbano, buscando as conjunções e aproximações possíveis para se estabelecer um diálogo entre o cemitério e a cidade. 
Img.81

(el sr garcia, com edição do autor)

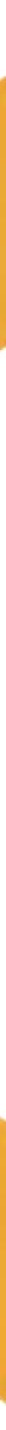





\section{Considerações finais}

"No dia seguinte ninguém morreu" (SARAMAGO, 2005, p.11). Em As intermitências da morte, Saramago conta a história de um pequeno país onde, de um dia para o outro, as pessoas deixam de morrer. Sem a morte, mesmo quem deveria morrer continuou vivo, em uma espécie de estado suspensão. O que começou como felicidade geral, logo apresentou uma variedade de complicações e contradições. Expondo todos os problemas que uma supressão da morte implicaria, Saramago inverte simbolicamente os papeis entre vivos e mortos através do comportamento. Quando o caos começa a se instalar, as pessoas ficam cada vez menos humanas enquanto que a morte vai se tornando mais humanizada. Assim, o livro de Saramago apresenta uma reflexão sobre a importância de morrer e como esse simples fato altera a vida de todos que vivem. A morte é, ao mesmo tempo, estruturadora e desestruturadora da vida. Ela está presente conosco todos os dias, moldando nossos comportamentos e definindo nosso senso mais profundo de vida, está incorporada dentro de nós: é nossa teleologia. 
Ao refletir sobre como a morte se apresenta perante a vida, é possível pensar tanto sobre a ideia de destino imaterial, que compreende questões mais abstratas, como também sobre a destinação material, que está relacionada com temas mais concretos. Enquanto o destino imaterial envolve noções que perpassam o desconhecido, o indefinido, a destinação trata de aspectos mais palpáveis, que demandam definições. Assim, tendo em vista ambos estes sentidos, esta dissertação procurou discutir a posição e a composição dos espaços de cemitério a partir do reconhecimento de que este tema compreende uma realidade das mais complexas, envolvendo atributos de campos sensíveis como as afetividades, a vinculação e o amparo. Portanto, busca-se sublinhar que o cemitério é o espaço onde a morte se afirma, assumindo importância como meio para localizá-la, para permitir a continuidade das relações post mortem e para expressar representações fúnebres, assumindo o papel de memento mori.

Ao mesmo tempo, ao se pensar no contexto urbano de São Paulo, percebe-se que esta cidade, durante o século XX e começo do século XXI, foi configurada de modo funcionalizado, fragmentado. Uma cidade onde interesses privados sobrepuseram-se aos públicos, baseada em soluções fetichistas que fracassaram constantemente em assimilar as suas sensibilidades e vulnerabilidades. São Paulo fez e continua fazendo escolhas duvidosas: a preferência por espaços lucrativos em detrimento de espaços verdes, públicos e de acesso público; a equivocada hegemonia dada ao transporte individual; a produção de instâncias que em vez de combater a especulação imobiliária associam-se a ela; a concentração de equipamentos em grandes complexos fechados a seu entorno; assim como, possivelmente, o maior indutor destes problemas, a preponderância de interesses de grupos política e economicamente dominantes que faz essas escolhas.

A inclinação a estas formas de atuação acaba por reduzir o pensamento urbano a sistemas de organização de fluxos, de usos predefinidos e de distribuição de infraestruturas, empobrecendo o debate a respeito da cidade. Com isso, favorece-se a funcionalização do espaço e a quase-anulação de sua dimensão simbólica, de sua potência como espaço de encontro e de construção de novas possibilidades de sentido, de apropriações e do convívio das alteridades. É esta 
cidade que vê como normal o encerramento não apenas dos seus cemitérios, mas de inúmeras práticas socioespaciais, oferecendo não apenas espaços, mas também cotidianos fragmentados. Desse modo, não é de se estranhar que, além das questões envolvidas na dificuldade de se relacionar com a esfera fúnebre, os cemitérios passaram a se encontrar de forma dissociada da dinâmica urbana, espaços que foram fagocitados pela cidade, mas que não se dissolveram nela, como uma mistura de densidades diferentes que não quer se agregar.

No entanto, se durante boa parte do século XX o pensamento sobre a sociedade e a cidade teve como pressuposto ideais mais unificadores e totalizantes, baseados em conceitos mais próximos ao modernismo, as novas circunstâncias apontam para caminhos mais maleáveis, representados pela noção de associação de instâncias plurais. Assim, de modo a refletir sobre a condição majoritariamente hermética que define o isolamento entre mortecemitério e sociedade-cidade, propôs-se pensar sobre os possíveis meios de mediação dessas questões em diversos aspectos, como a limitação encontrada para se indicar a destinação do corpo e os entraves afetivos, sociais e espaciais que ela acaba acarretando.

Apesar do crescimento da cremação representar uma maior variação frente ao domínio do enterro como alternativa regular, pouco se discute a respeito de outras formas de se estabelecer a destinação do cadáver no contexto brasileiro. Procurou-se mostrar que, ao deixar de lado concepções mais restritas, à luz das mudanças sociais e urbanas em curso, é possível discutir outros meios para pensar o lugar dos mortos que levem também em conta a dinâmica dos ambientes contemporâneos. Nesse sentido, ao imaginar a introdução de aspectos ligados às questões fúnebres nos interstícios urbanos, ao se transpor o muro simbólico e físico dos cemitérios, é possível vislumbrar a difusão do espaço da morte junto à cidade, de modo que o estabelecimento de uma lógica de integração pode levar à formação de um sentido de interação. Assim, o poder atmosférico, afetivo e simbólico desses lugares poderia ser posto a serviço do desenvolvimento da experiência urbana, contribuindo para a concepção de espaços que podem amplificar a convivência e o encontro em uma cidade mais acolhedora e includente. 


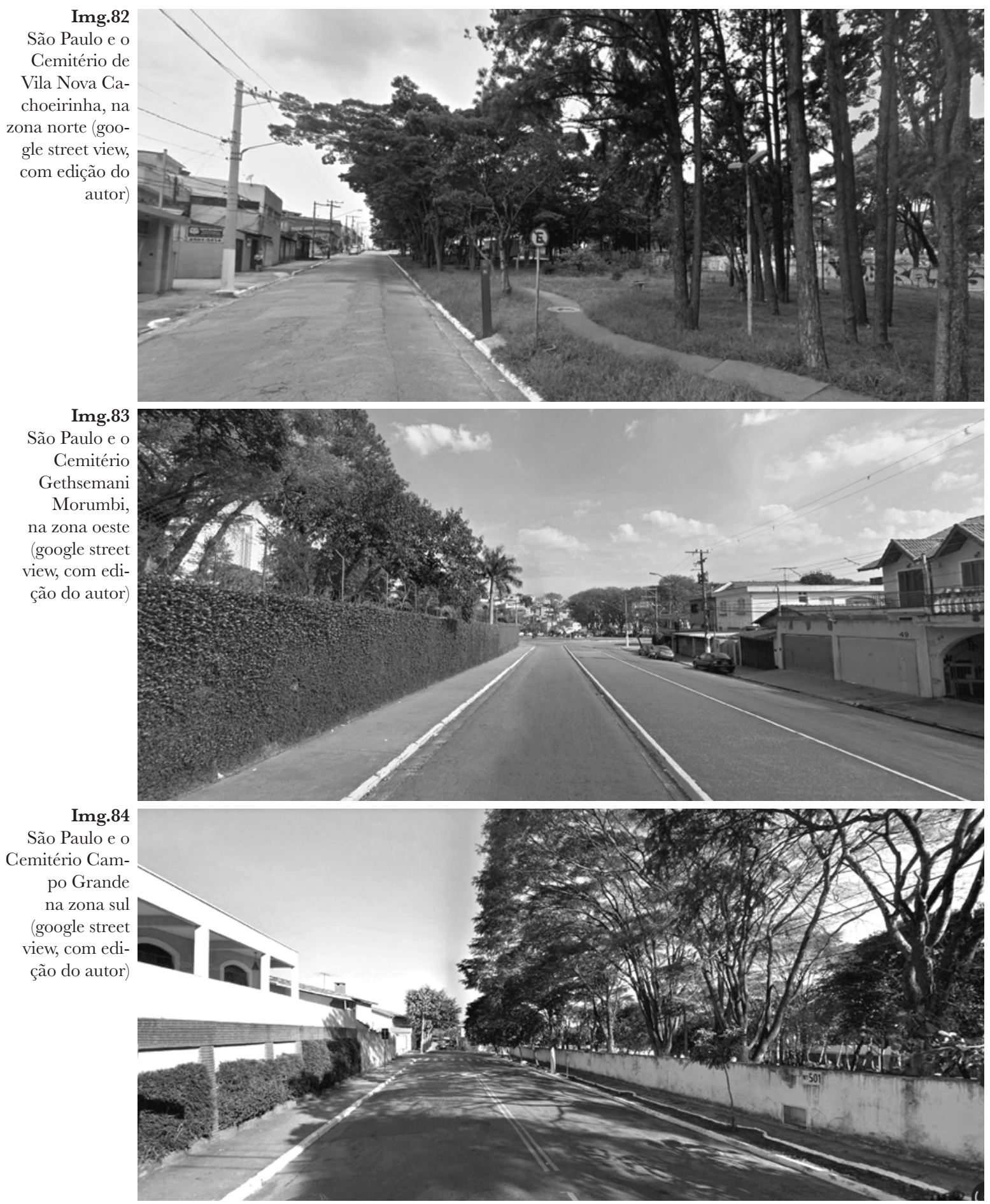



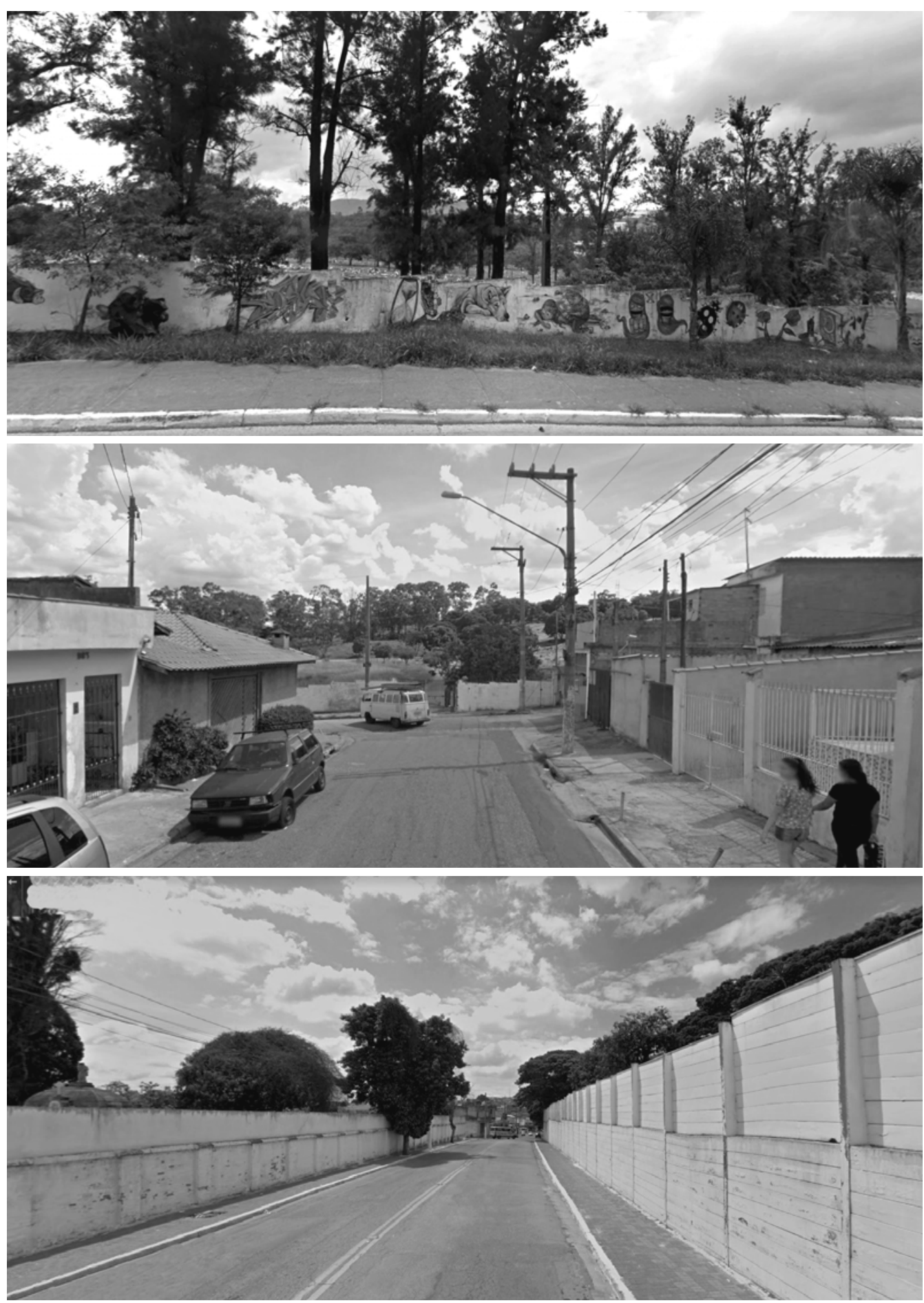

Img.87

São Paulo e o

Cemitério Lajeado, na zona leste

(google street view, com edição do autor) 

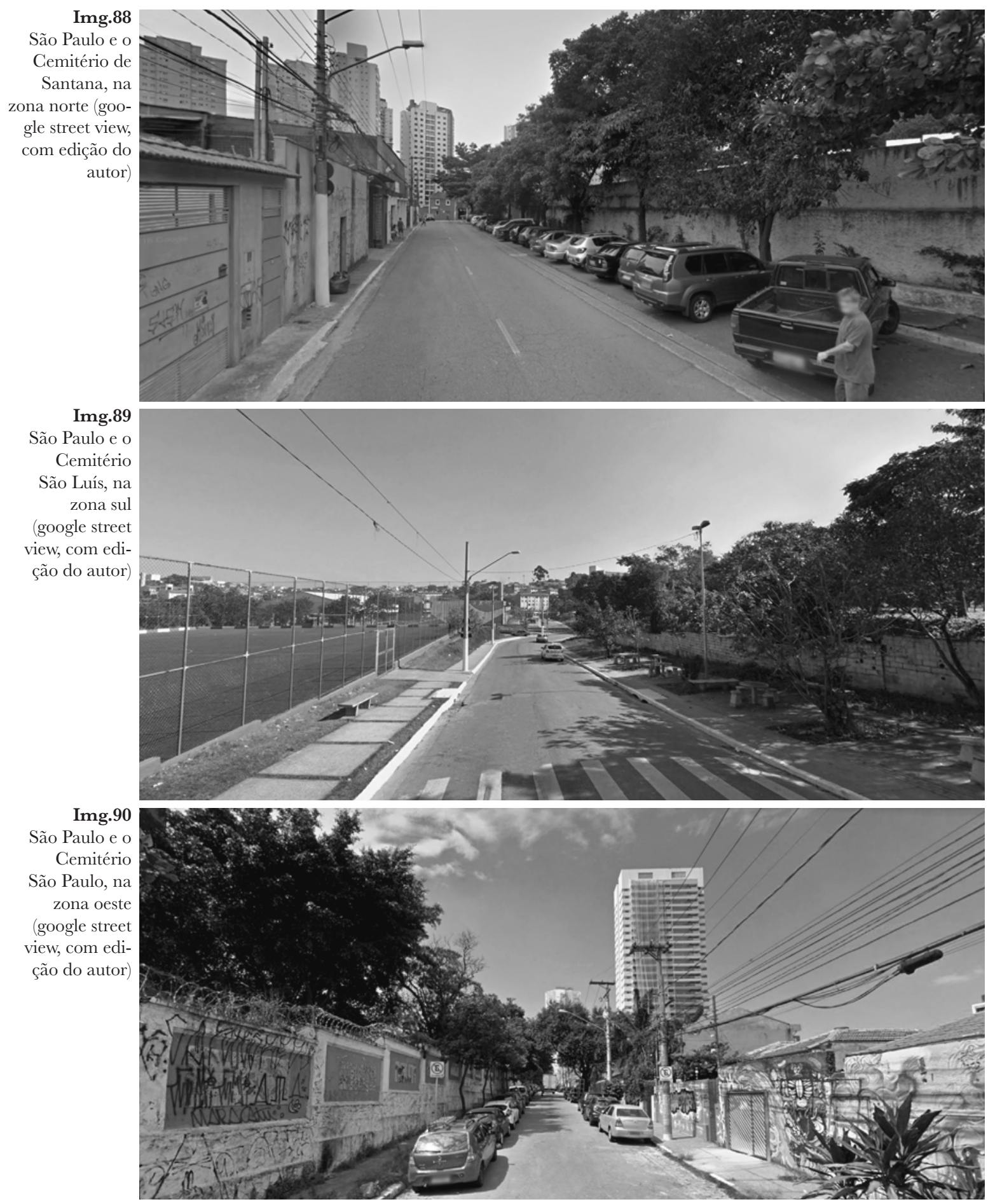


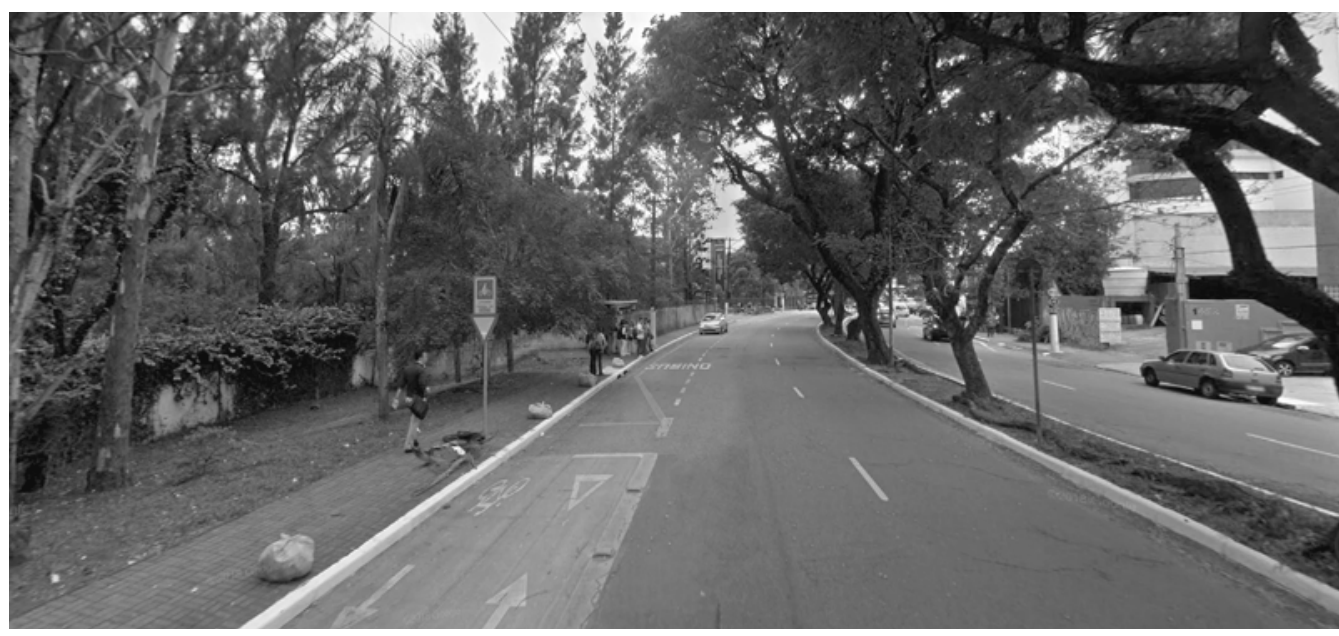

Img.91

São Paulo e o

Cemitério

São Pedro, na

zona leste

(google street

view, com edi-

ção do autor)

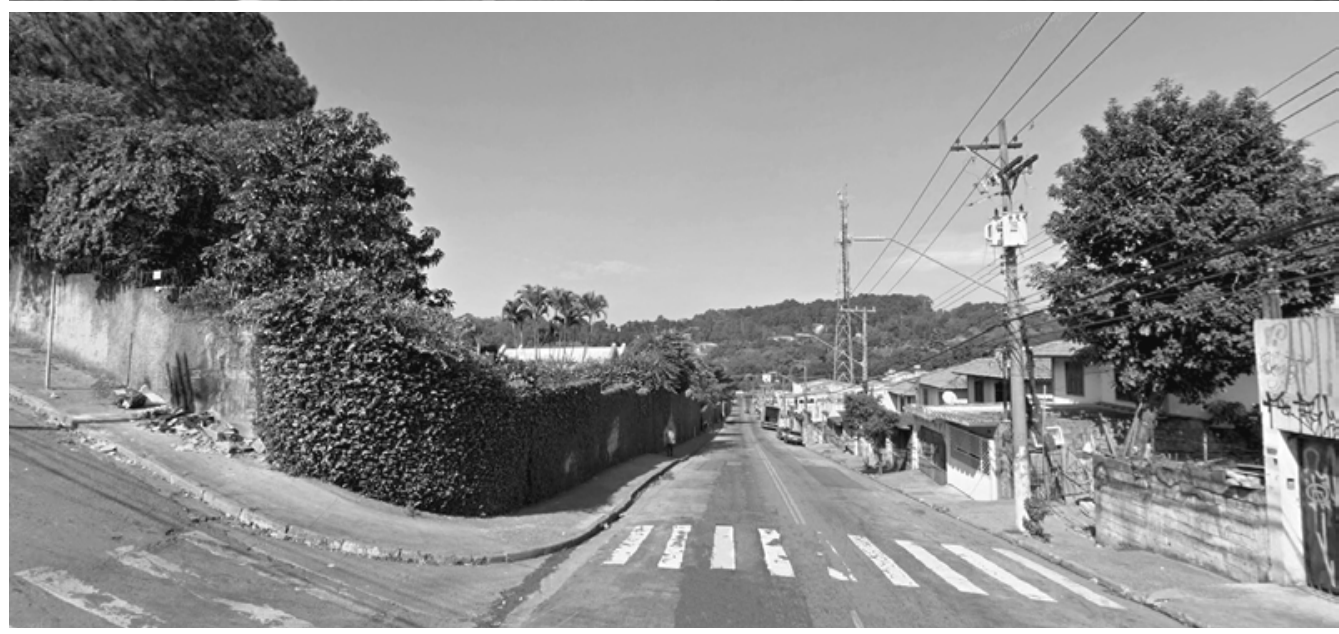

Img.92

São Paulo e o Cemitério Israelita do Butantã, na zona oeste (google street view, com edição do autor)

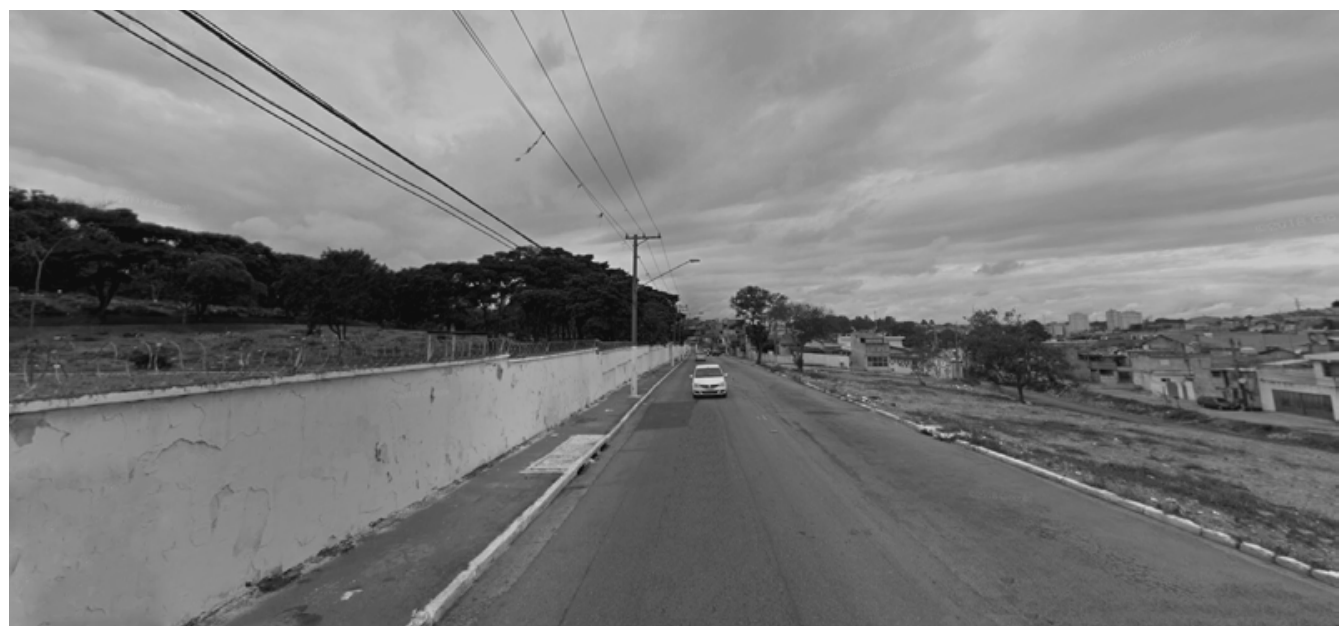

Img.93

São Paulo e o Cemitério da Saudade, na zona leste (google street view, com edição do autor) 
Ao trazer uma reflexão sobre cidade e a sua forma de vinculação com os espaços fúnebres, buscou-se reconhecer o cemitério como um espaço a ser incluído nas estratégias de desenvolvimento urbano de modo a articular não apenas as questões sociais (como memória, historicidade, sociabilidade, solidariedade, etc.), mas também as ambientais (como qualidade do ar, conforto térmico, absorção de águas, ecossistema urbanos, etc. $)^{119}$. Os sistemas urbanos contemporâneos têm buscado cada vez mais desenvolver na cidade estruturas ambientais que quebrem a fragmentação do território através da continuidade ecológica. Em São Paulo, os espaços de cemitério representam a segunda maior parcela de áreas verdes do município, atrás apenas dos parques e praças. Portanto, é preciso ter em mente o papel desses lugares tanto nos quesitos de apropriação de usos cotidianos, como na determinação das estruturas ecológicas da cidade. Assim, ao refletir sobre a importância dos processos sociais e ambientais urbanos, é possível imaginar que a inscrição da morte junto aos espaços de uma cidade como São Paulo pode, inclusive, ser parte geradora de um processo de renovação espacial.

Para tal, procurou-se acentuar que cada situação requer

119

Para ver mais sobre

a relevância dos

processos naturais no meio urbano cf.

O jardim de granito:

natureza no desenho

da cidade.

Anne Spirn, 1995. uma leitura específica de suas as sensibilidades, simbolismos e peculiaridades através das possibilidades que seu contexto oferece, como sugeriu-se no ensaio (ensejo) sobre o Vila Formosa. A busca pela compreensão das questões relativas à morte e ao cemitério leva a inúmeros caminhos e aborda temas que perpassam as múltiplas instâncias da vida. Portanto, não se deve olhar para esta pesquisa como fonte de respostas unívocas e precisas, visto que buscou-se trabalhar suas nuances de forma mais investigativa do que deliberativa. Nesse sentido, salienta-se que a intenção desta dissertação não foi a de indicar este ou aquele caminho como resposta determinada, mas abrir o horizonte para uma variedade de possibilidades, alternativas e reflexões. Assim, espera-se que através das questões desenvolvidas até aqui, este trabalho seja capaz de suscitar reflexões e contribuir para se pensar sobre as formas como o cemitério se configura em nossa sociedade, e como ele dialoga (ou não) com cidades em constante transformação como São Paulo. 
O esforço desta pesquisa orientou-se no sentido de mostrar como os espaços de cemitério, frequentemente ignorados, podem se configurar de variadas formas, inclusive de modo a ampliar as predefinições estabelecidas a seu respeito. Ao longo do seu desenvolvimento, procurou-se vislumbrar uma atmosfera propícia às conexões onde a dilatação pode ser capaz de integrar instâncias que parecem opostas, mas devem ser vistas como complementares: o urbano e o ecológico; o público e o íntimo; o estático e o dinâmico; o passado e o futuro; a vida e a morte.

Por fim, ressalta-se a importância de refletir sobre âmbitos e instâncias em que os espaços de cemitério podem projetar-se de forma abrangente, deixando de se apresentar como encraves para se tornarem extensões do meio urbano. Resta, então, abrir-se, permitir o atrito, consentir que a atmosfera dos espaços fúnebres seja percebida e, quem sabe, represente um convite a uma cultura afetiva, sensível, de encontro e amparo ao outro. Acredita-se que ao permitir abraçar as possíveis integrações e interações entre os espaços de cemitério e a cidade, boa parte das pessoas possa se surpreender. 

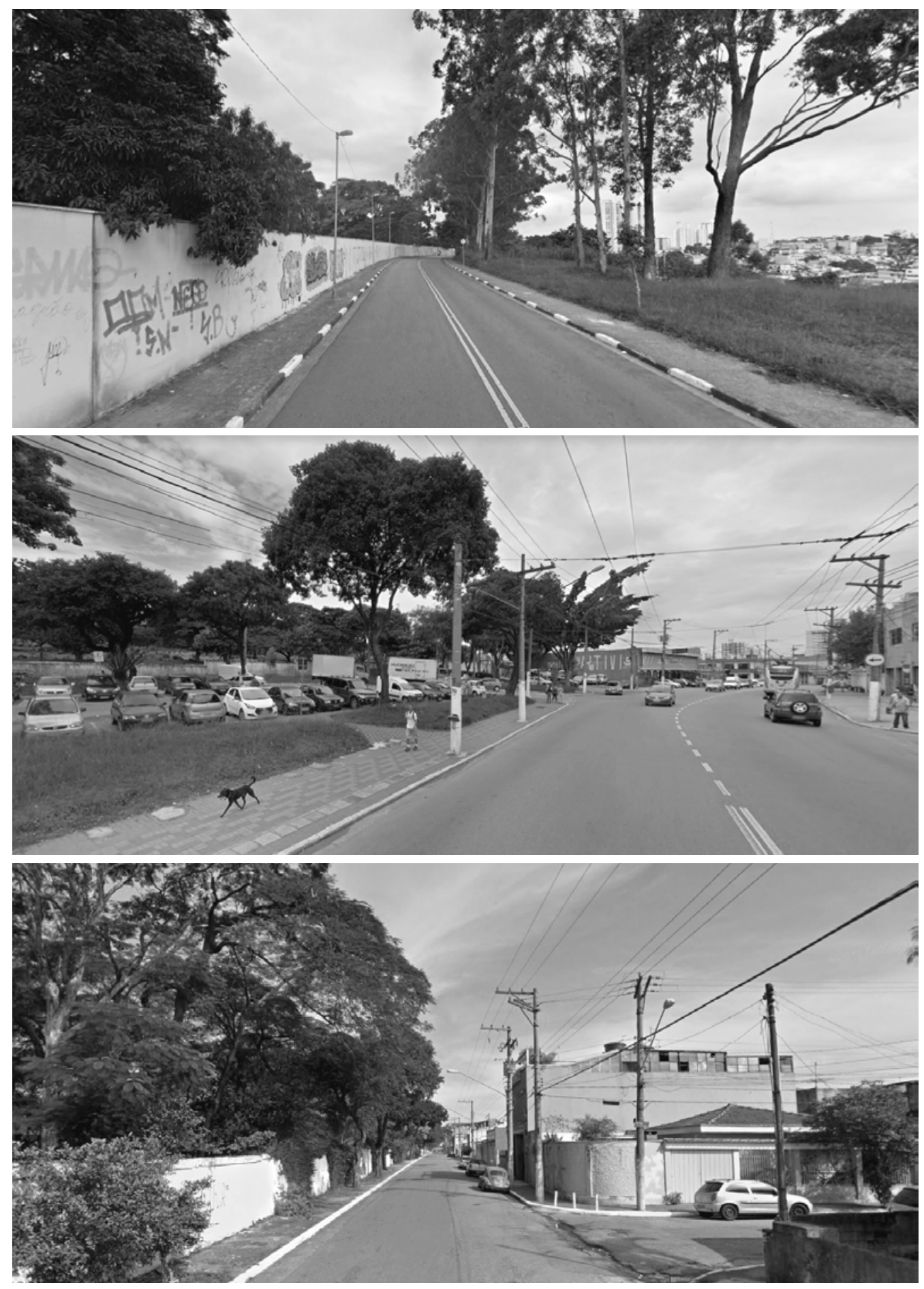

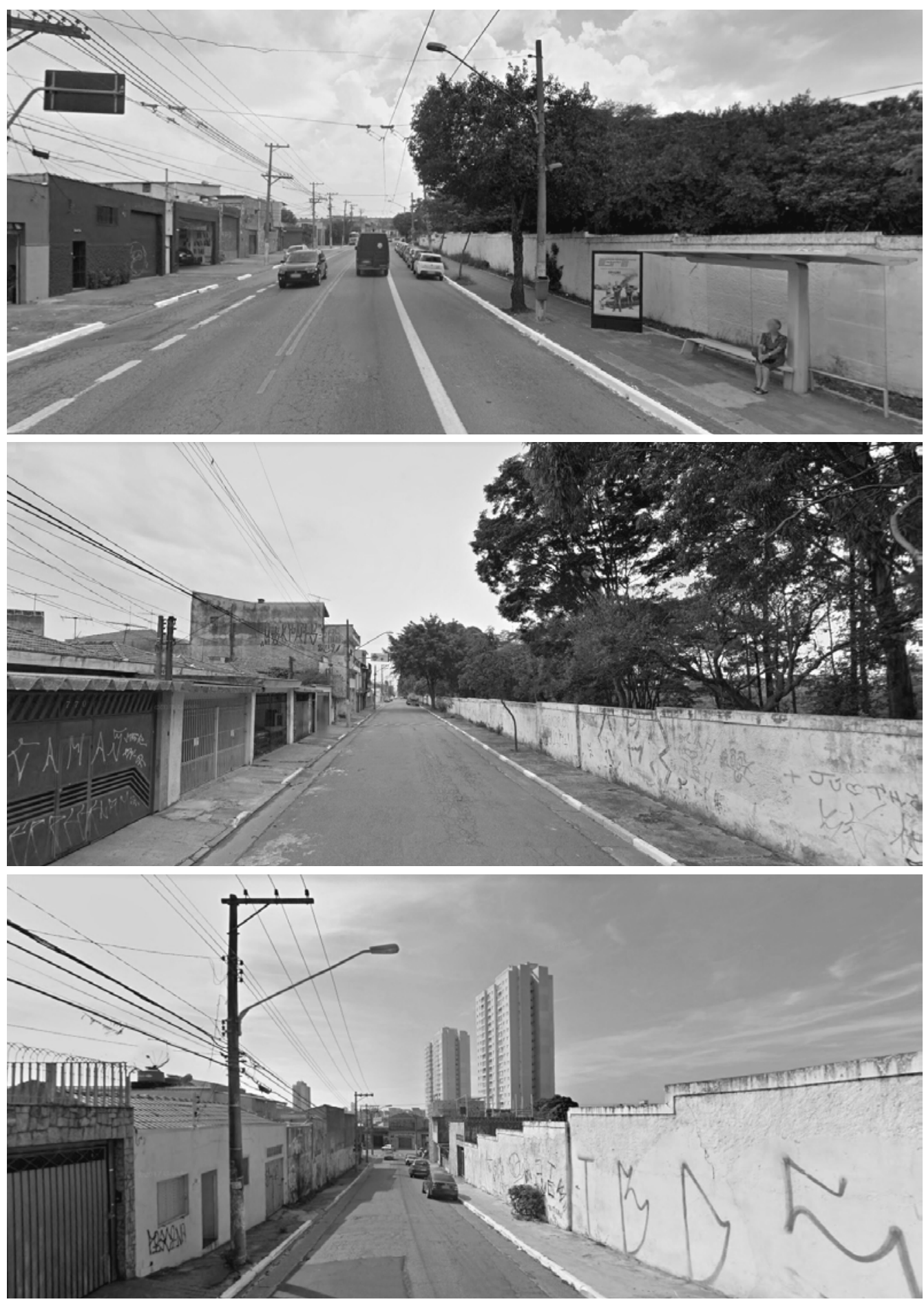

Img.94 a 99

São Paulo e o

Cemitério da

Vila Formosa,

na zona leste

(google street

view, com edi-

ção do autor) 



\section{Referências}

ANDERSSON, Thorbjörn. The Functionalism of the Gardening Art. In Sweden: 20th-

Century Architecture, ed. C. Caldeerly, J. Lindvall and W. Wang. Nova Iorque, 1998.

ARIÈS, Philippe. Sobre a história da Morte no Ocidente desde a Idade Média. Trad. Pedro Jordão. Lisboa: Editora Teorema, 2010.

ARIÈS, Philippe. O Homem diante da Morte. Trad. Luiza Ribeiro. S. Paulo: Ed. Unesp, 2014 ASSEMBLEIA LEGISLATIVA DO ESTADO DE SÃO PAULO. Decreto $n^{\circ} 16.017$, de 4 de novembro de 1980. Disponível em <www.al.sp.gov.br/repositorio/legislacao/decreto/1980/ decreto-16017-04.11.1980.html> Acesso em: 10 jan. 2019.

AUZELLE, Robert. Derniéres demeures: conception, composition, réalisation du cimetiére contemporain. Paris: Place du Panthéon, Mazarine, 1965.

BAUDRILLARD, Jean. A troca simbólica e a morte. Trad. Maria Estela Gonçalves e Adail Ubirajara Sobral. São Paulo: Edições Loyola, 1996.

BARTALINI, Vladimir. Parques Públicos Municipais de São Paulo: a ação da municipalidade no provimento de áreas verdes de recreação. Tese de doutorado. Faculdade de Arquitetura e Urbanismo da Universidade de São Paulo. São Paulo, 1999.

BAYARD, Jean-Pierre. Sentido oculto dos ritos funerários: Morrer é morrer? Tradução: Benôni Lemos. São Paulo: Paulus, 1996.

BELTING, Hans. Antropologia da imagem. Trad. Artur Mourão. Lisboa: KKYM, 2014.

BERQUE, Augustin. El pensamiento paisajero. Trad. J. Maderuelo. Madrid: Biblioteca Nueva, 2009. BRASIL. Lei no 10.406, de 10 de janeiro de 2002. Institui o Código Civil. Brasília: Presidência da República. Casa Civil. Disponível em: <http://www.planalto.gov.br/ccivil_03/leis/2002/ L10406.htm>. Acesso em: 31 jul. 2017.

C3 MAGAZINE. n²91, novembro de 2008. Idea Books: Coreia do Sul. p.38-47

CARPENTER, David. Geopiety, 2008. Disponível em <www.dccarpenter.com/geopiety.htm> Acesso em: 15 nov. 2018.

CASTRO, Luiz Guilherme Riveira de. De outros tempos e lugares: notas sobre o conceito de heterotopia a partir de Michel Foucault. In. Territórios e Temporalidades. Trabalho de conclusão de pesquisa. Org. Igor Guatelli. São Paulo: Universidade Presibteriana Mackenzie, 2014. 
CATROGA, Fernando. Morte romântica e religiosidade cívica. In: MATTOSO, fosé. História de Portugal: O Liberalismo. Lisboa: Editorial Estampa, 1993.

CATROGA, Fernando. O culto dos mortos como uma poética da ausência. In: ArtCultura, Uberlândia, v.12, n²0, p.163-182, jan.-jun. 2010.

CAUE 44 (Conseil en Architecture, Urbanisme et Environnement de Loire-Atlantique). De la pierre à l'herbe, des cimetières en mutation. Lettre d'information nº10. Maio de 2011.

CERTEAU, Michel de. A invenção do cotidiano - Artes de fazer. Trad. Ephraim Alves. Petrópolis: Editora Vozes, 1998.

CONAN, Michel. Perspectives on Garden Histories. Washington: Dumbarton Oaks, 1999. CONNELLY, Lindsay Mae. Life, death, and design: revisiting Aldo Rossi's cemetery at San Cataldo. Master of Science, The Pennsylvania State University, 2017.

CHARLET, Christian. Le Père-Lachaise: Au coeur du Paris des vivants et des morts. Paris: Gallimard, 2003.

CURL, James Stevens. Fohn Claudius Loudon (1783-1843) and the Cemetery Movement.

Southampton: Friends of Southampton Old Cemetery, 2008.

CYMBALISTA, Renato. Cidade dos Vivos: Arquitetura e atitudes perante a morte nos cemitérios do estado de São Paulo. São Paulo: Annablume: Fapesp, 2002.

DA SILVA, Justino Adriano Farias. Tratado de direito funerário. São Paulo: Método Editora, 2000. DEFERT, Daniel e FOUCAULT, Michel. Le corps utopique, les hétérotopies. Paris: Lignes, 2009. FIX, Reinaldo Guilherme. Os muros que separam os mortos: um estudo de caso dos cemitérios da Consolação, dos Protestantes e da Ordem Terceira do Carmo. Faculdade de Filosofia, Letras e Ciências Humanas, Departamento de Geografia. São Paulo, TGI: 2007.

DEBRAY, Régis. Vida e morte da imagem: uma história do olhar no ocidente. Trad. Guilherme Teixeira. Petrópolis: Vozes, 1993.

DIDI-HUBERMAN, Georges. O que vemos, o que nos olha. Trad. Paulo Neves. São Paulo: Editora 34, 1998.

DIDI-HUBERMAN, Georges. Génie du non-lieu. Paris: Les Éditions de minuit, 2001. DOLFF-BONEKAMPER, Gabi. Caminhando pelo passado dos outros, 2014. In: CYMBALISTA, R., FELDMAN, S., KUHL, B. (Org.). Patrimônio cultural: memória e intervenções urbanas. São Paulo: Annablume/FAPESP, 2017. p.61-87 DOWNING, Andrew Jackson. Public cemeteries and public gardens. In: The horticulturist vol.4, nº 1 , julho de 1849, p.9-12. 
DUGOS, Teresa. A experiência estético-metafísica de "os alpes" sobre a génese da stimmung em Georg Simmel. In: Philosophica n42, Lisboa, 2013, p.23-36.

EGGENER, Keith. Cemeteries. N.Y: W.W. Norton \& Company; Library of Congress, 2010. ETZEL, Eduardo. O verde na cidade de São Paulo. In: Revista do Arquivo Municipal, São Paulo: Divisão do Arquivo Histórico, nº195, 1982. p.51-76

FERES, Elisa, MATSUMOTO, Victoria e SANTOS, Fábio. Vila Formosa: veja a estrutura do maior cemitério brasileiro. Portal Terra. Disponível em <www.terra.com.br/noticias/brasil/ cidades/cemiterio-vila-formosa-veja-a-estrutura-do-maior-cemiterio-brasileiro,612771f68d5228 2bba38ab0b6c0ddf9f2snmRGRD.html> Acesso em: 3 dez. 2017.

FOUCAULT, Michel. Outros espaços. Trad. Inês Barbosa. In. Estética: literatura e pintura, música e cinema. Coleção Ditos \& Escritos III. Rio de Janeiro: Forense Editora, 2001 (1984). p.411-422 FRANCIS, Doris. Cemeteries as cultural landscapes. Mortality, Vol. 8, № 2, 2003. Disponível em <www.d.umn.edu/cla/faculty/jhamlin/4960/Cems.pdf> Acesso em: 18 nov. 2018.

FRANCIS, Doris, KELLAHER, Leonie e NEOPHYTOU, Georgina. Sustaining cemeteries: the user perspective. In: Mortality, vol.5:1, 2000, p.34-52.

FUMAGALLI, Vito. Landscapes of Fear: Perceptions of Nature and the City in the Middle Ages. Cambridge: Polity, 1994.

GIBBONS-NEFF, Thomas. People are now playing Pokémon Go at Arlington Cemetery. Washington Post. Disponível em www.washingtonpost.com/news/checkpoint/wp/2016/07/12/ arlington-national-cemetery-wants-people-to-stop-catching-pikachu-on-its-hallowedround/?noredirect=on\&utm_term=.56a52336dfe2. Acesso em: 16 jan. 2019.

GILI, Monica. La última casa. Barcelona: Gustavo Gili, 1999.

GINZBURG, Carlo. Ecstasies: deciphering the witches' Sabbath. Tradução Raymond Rosenthal. Nova Iorque: Pantheon Books, 1991.

GORER, Geoffrey. The pornography of death. In: Encounter, Outubro de 1955. p.49-52

GRASSI, Clarissa. Memento Mortuorum: inventário do Cemitério Municipal S. Francisco de Paula em Curitiba/PR. In: Anais VII Congresso Internacional Imagens da Morte. São Paulo, 2016. GUATELLI, Igor. Arquitetura dos entre-lugares: sobre a importância do trabalho conceitual.

São Paulo, Senac, 2012.

GUNTER, JOEL. Yolocaust: how should you behave at a Holocaust memorial? BBC News.

Disponível em <www.bbc.com/news/world-europe-38675835> Acesso em: 16 jan. 2019.

HALLAM, Elizabeth e HOCKEY, Jenny. Death, memory and material culture. Oxford: Berg, 2001. 
HATUKA, Tali. A obsessão pela memória: o que ela faz com os outros e com as nossas cidades, 2015. In: CYMBALISTA, R., FELDMAN, S., KUHL, B. (Org.). Patrimônio cultural: memória e intervenções urbanas. São Paulo: Annablume/FAPESP, 2017. p.47-60

HARRISON, Robert. The dominion of the dead. Chicago: University of Chicago Press, 2003.

HAYS, Kenneth Michael. Architecture's desire: Reading the late avant-garde, Cambridge: MIT Press, 2010.

HEATHCOTE, Edwin. Monument Builders: Modern Architecture and Death. Chichester:

Wiley, 1999.

HERTZ, Robert. Contribuição a um estudo sobre a representação coletiva da morte. Sociologia Religiosa e Folclore. Trad. Petrópolis: Vozes, 2016.

HOUGH, Michael. Naturaleza y ciudad: Planificación urbana y processos ecológicos.

Barcelona: Gustavo Gili, 1998

HUYSSEN, Andreas. Culturas do passado-presente: modernismo, artes visuais, políticas da memória. Tradução Vera Ribeiro. Rio de Janeiro: Contraponto, 2014.

JOHNSON, Peter. The cemetery: a highly heterotopiaplace. Plataforma Heterotopian Studies:

2012. Disponível em <www.heterotopiastudies.com> Acesso em: 15 nov. 2018.

KING, Alex. Memorials of the Great War. Oxford: Berg, 1998.

KOVÁCS, Maria Júlia. Educação para a morte: temas e reflexões. São Paulo: Casa do

Psicólogo: Fapesp, 2008.

KÜBLER-ROSS, Elisabeth. Sobre a morte e o morrer. São Paulo: Martins Fontes, 1992.

LE GOFF, Jacques. História e memória. Tradução Bernardo Leitão. Campinas: Editora da Unicamp, 1990.

LIGOU, Daniel. L'Evolution des cimetières. In: Archives de sciences sociales des religions, $\mathrm{n}^{\circ} 39,1975$. p.61-77

LOOS, Adolf. Architektur (1910). In: MÜNZ, Ludwig, KÜNSTLER Gustave. Adolf Loos:

Pioneer of Modern Architecture. Nova Iorque: Praeger, 1966.

LOUREIRO, Maria Amélia Salgado. Origem Histórica dos Cemitérios. São Paulo, 1997.

MAGNANI, José Guilherme Cantor. Da periferia ao centro: trajetórias de pesquisa em

Antropologia Urbana. São Paulo, Editora Terceiro Nome, Coleção Antropologia Hoje, 2012.

MAGNANI, José Guilherme Cantor. De perto e de dentro: notas para uma etnografia urbana.

In: Revista Brasileira de Ciências Sociais, vol 17, n49, junho 2002.

MATRANGOLO, Breno Henrique Selmine. Formas de bem morrer em São Paulo: 
transformações nos costumes fúnebres e a construção do cemitério da Consolação (1801- 1858).

Dissertação de Mestrado em História. Universidade de São Paulo: São Paulo, 2013.

MENGUE, Priscila. Cemitério vira espaço de leitura na zona sul de São Paulo", de Priscila Mengue.

O Estado de S.Paulo, 2017. Disponível em <sao-paulo.estadao.com.br/noticias/geral,cemiterio-viraespaco-de-leitura-na-zona-sul-de-sao-paulo,70001740686>. Acesso em: 16 jan. 2019.

MITFORD, Jessica. The american way of death revisited. Nova Iorque: Vintage, 2000.

MOORE, Matthew. Facebook introduces 'memorial' pages to prevent alerts about dead members. The Telegraph, 2009. <www.telegraph.co.uk/technology/facebook/6445152/Facebookintroduces-memorial-pages-to-prevent-alerts-about-dead-members.html> Acesso em: 5 jan. 2019. MORGADO, Almir. A natureza jurídica do uso de sepultura. In: Boletim furídico, Uberaba, n 225 , 2007. Disponível em: <www.boletimjuridico.com.br/doutrina/artigo/1789/a-naturezajuridica-uso-sepultura> Acesso em: 28 nov. 2018.

MORIN, Edgar. O homem e a morte. Trad. Cleone Rodrigues. Rio de Janeiro: Imago, 1997. MORLEY, David. Home territories: media, mobility and identity. London: Routledge, 2000. NORA, Pierre. Entre memória e história: a problemática dos lugares. Tradução Yara Aun Khoury. In: Revista Projeto História. São Paulo, v.10, 1993. p.7-28

PENTEADO, Fábio. Fábio Penteado: ensaios de arquitetura. São Paulo: Empresa das Artes, 1998.

PREFEITURA MUNICIPAL DE SÃO PAULO (PMSP-SFMSP) E FUNDAÇÃO SÃO

PAULO - PUC-SP (FUNDASP). Projeto de Pesquisa e Extensão Memória \& Vida - Cemitério da Consolação. São Paulo, 2016.

PREFEITURA MUNICIPAL DE SÃO PAULO (PMSP). Plano Diretor Estratégico do Município de São Paulo. Lei N No 14.430. São Paulo, 2002.

PREFEITURA MUNICIPAL DE SÃO PAULO (PMSP). Plano Diretor Estratégico do Município de São Paulo. Lei No 16.050. São Paulo, 2014.

PREFEITURA MUNICIPAL DE SÃO PAULO (PMSP-SMDP). Edital de Chamamento Público no 03/2017. São Paulo, 2017.

PREFEITURA MUNICIPAL DE SÃO PAULO (PMSP). A to Prefeito nº 2 6, 21 março de 1932. QUEIROGA, Eugenio Fernandes. Dimensões públicas do espaço contemporâneo: resistências e transformações de territórios, paisagens e lugares urbanos brasileiros. Tese (Livre docência)Faculdade de Arquitetura e Urbanismo, Universidade de São Paulo, São Paulo, 2012.

REIS, João José. A morte é uma festa: ritos fúnebres e revolta popular no Brasil do século XIX. São Paulo: Companhia das Letras, 1991. 
REZENDE, Eduardo Coelho Morgado. Metrópole da morte necrópole da vida: um estudo geográfico do Cemitério de Vila Formosa. São Paulo: Carthago, 2000.

REZENDE, Eduardo Coelho Morgado. O céu aberto na terra: uma leitura dos cemitérios na geografia urbana de São Paulo. São Paulo: E.C.M, 2006.

RIBEIRO, Renata Rezende. A morte midiatizada: como as redes sociais atualizam a experiência do fim da vida. Rio de Janeiro: Eduff, 2015.

RIVAS, Tatiana. El Atlético de Madrid planea construir un columbario en el Wanda para trasladar las cenizas de sus socios. ABC. Disponível em <www.abc.es/espana/ madrid/abci-atletico-madrid-planea-construir-columbario-wanda-para-trasladar-cenizassocios-201812040208_noticia.html> Acesso em: 10 jan. 2019.

RODRIGUES, José Carlos. Tabu da Morte. Rio de Janeiro: Editora Fiocruz, 2006.

RODRIGUEZ, Maria Inês Fernandez. Um olhar para a despedida: Um estudo do luto antecipatório e sua implicação no luto pós-morte. Dissertação de Mestrado em Psicologia Clínica. Pontifícia Universidade Católica de São Paulo, 2014.

ROSSI, Aldo. Autobiografia científica. Coimbra: Edições 70 - Almedina, 2013.

ROTHSTEIN, Karla Maria. Propostas alternativas para cemitérios urbanos enquanto santuários e espaços de memória na contemporaneidade. In: Revista M., vol 1, nº1, p.107-127, jan-jun 2016. Disponível em < www.revistam-unirio.com.br/propostas-alternativas-para-cemiterios-urbanoscomo-santuarios-e-espacos-de-memoria-na-contemporaneidade> Acesso em: 26 abr. 2017. SANTOS A., Aline Silva. Morte e Paisagem: Os Jardins de Memória do Crematório Municipal de São Paulo. Tese de Mestrado, Universidade de São Paulo: São Paulo, 2015.

SANTOS C., Carolina Junqueira dos. O corpo, a morte, a imagem: a invenção de uma presença nasfotografias memoriais e postmortem Tese de doutorado. Universidade Federal de Minas Gerais, Escola de Belas Artes, 2015.

SARAMAGO, José. As intermitências da morte. São Paulo: Companhia das Letras, 2005.

SCHUYLER, David. New Urban Landscape. USA: e Johns Hopkins University Press, 1986.

SECGHI, Bernardo, VIGANÒ, Paola. La ville poreuse. Paris: Métispresses, 2012.

SELIGMANN-SILVA, Márcio. Antimonumentos: trabalho de memória e de resistência.

Psicologia USP, v. 27, n. 1, 2016. Disponível em <www.revistas.usp.br/psicousp/article/ view/114752/112487> Acesso em: 27 abr. 2017.

SERRÃO, Adriana Veríssimo. Filosofia da paisagem: uma antologia. Lisboa: Centro de Filosofia da Universidade de Lisboa, 2011. 
SIMMEL, Georg. A ponte e a porta [1909]. Trad. de Simone Maldonado. In: Revista Política E Trabalho, ed.12, Editora Universitária da UFPB. Setembro de 1996, p.11-15

SIMMEL, Georg. A Filosofia da paisagem. Tradução de Artur Morão. Covilhã: LusoSofia, 2009.

SLOANE, David Charles. The last great necessity: cemeteries in American history. Baltimore:

Johns Hopkins University Press, 1995.

SOLÀ-MORALES, Manuel. Espaços públicos e espaços coletivos. In: HUET, Bernard et al.

Os centros das metrópoles: reflexões e propostas para a cidade democrática do século XXI. São

Paulo: Terceiro Nome, 2001. p.101-107

SPIRN, Anne. O jardim de granito: natureza no desenho da cidade. São Paulo: EDUSP, 1995.

STAVRIDES, Stavros. Towards a City of Thresholds. Professional Dreamers. 2010. Disponível em <www.professionaldreamers.net/_prowp/wp-content/uploads/978-88-904295-3-8.pdf> Acesso em: 10 jul. 2018.

STROEBE, Margaret, SCHUT, Henk. The dual process model of coping with beravent: rationale and description. In: Death Studies, Vol. 23, Issue 3 1999. p.197-224

TELES, Janaína de Almeida. Luto e Memória da ditadura: O Memorial dos Desaparecidos de Vila Formosa, em São Paulo. Revista M., Rio de Janeiro, vol. 2, n.3, p.65-93, jan/jun 2017. Disponível em <www.revistam-unirio.com.br/luto-e-memoria-da-dita dura-o-memorial-dosdesaparecidos-de-vila-formosa-em-sao-paulo> Acesso em: 3 de jan. 2018.

THE OUT LOUD JOURNAL (TOLJ). Death + Architecture. Issue 1. Estados Unidos: Arch Out Loud, 2017.

THIOLLIERE, Pascaline. L'urbain et la mort: ambiances d'une relation. Architecture, aménagement de l'espace. Université Grenoble Alpes, 2016.

THOMAS, Louis-Vincent. El cadáver: de la biología a la antropología. Trad. Juan Damonte. Cidade do México: Fondo de Cultura Económica, 1989.

TREIB, Marc, Modern landscape architecture: a critical review. Cambridge: MIT Press, 1994.

URBAIN, Jean-Didier. L'archipel des morts. Paris: Payot, 1998.

URBAIN, Jean-Didier. La société de conservation. Paris: Payot, 1978.

VAN GENNEP, Arnorld. Les rites de passage: étude systématique des rites de la porte et du seuil, de l'hospitalité, de l'adoption, de la grossesse et de l'accouchement, de la naissance, de l'enfance [1909]. Paris: Picard. 2011.

VOVELLE, Michel. Les attitudes devant la mort: problèmes de méthodes, approches et lectures différentes (note critique). In: Annales. Économies, Sociétés, Givilisations. 31 année, nº 1, 1976. 
p.20-132. Disponível em <www.persee.fr/doc/ahess_0395-2649_1976_num_31_1_293702> Acesso em: 10 out. 2018.

WALTER, Tony. Sociologists never die: british sociologists and death. In CLARK, David. The sociology of death: theory, culture, practice. Oxford: Blackwell Pub, 1993, p.273.

WILHEIM, Jorge. Projeto São Paulo: propostas para a melhoria da vida urbana. Rio de Janeiro: Paz e Terra, 1982.

WOODTHORPE, Kate. The material presence of absence: a dialogue between museums and cemeteries. In: Sociological Research Online Vol.13, Issue 5, 2008. Disponível em <www.socresonline.org.uk/13/5/1.html> Acesso em: 10 jul. 2018.

WORPOLE, Ken. Last landscapes: the architecture of the cemetery in the West. Londres: Reaktion Books, 2003.

WRIGHT, Elizabethada. Rhetorical spaces in memorial places: the cemetery as a rhetorical memory place/space. In: Rhetoric Society Quarterly, Vol.35, n4, p.51-81. Taylor \& Francis, 2005. ZIEGLER, Jean. Os vivos e a morte. Trad. A. Weissenberg. Rio de Janeiro: Zahar editores, 1977.

\section{Entrevistas}

LAURETTI, Mônica. Conversa sobre a concepção do Memorial Parque das Cerejeiras. Entrevista gentilmente concedida ao autor na Faculdade de Arquitetura e Urbanismo da Universidade de São Paulo. São Paulo, 8 de fevereiro de 2018.

PEREIRA, Hélia Gonçalves. Conversa sobre a Secretaria do Verde e Meio Ambiente (SVMA) e o Sistema Municipal de Áreas Protegidas, Áreas Verdes e Espaços Livres (SAPAVEL). Entrevista gentilmente concedida ao autor na sede da SVMA. São Paulo, 26 de novembro de 2018.

SALLES, Lúcia França Pinto. Conversa sobre a gestão do Serivço Funerário do Município de São Paulo. Entrevista gentilmente concedida ao autor na residência da entrevistada. São Paulo, 21 de novembro de 2017. 


\section{Sites consultados}

ArchDaily

www.archdaily.com

Arch Out Loud

www.archoutloud.com

Associação Cemitério Israelita de São Paulo www.acempro.com.br

Associação Cemitério dos Protestantes www.chevrakadisha.org.br

Association of Significant Cemeteries in Europe www.acempro.com.br

Cemitério do Carmo www.cemiteriodocarmo.com.br

Cemitério de Congonhas www.cemiteriocongonhas.com.br

Cemitério Gethsêmani www.gethsemani.org.br

Cemitério Parque dos Girassóis www.parquedosgirassois.com.br

Cemitério Parque da Cantareira www.cemiteriodomorumbi.com.br

Cemitério do Morumbi www.cemiteriocantareira.com.br

Cemitério Parque do Jaraguá www.cemiteriojaragua.com.br

Cemitério Parque dos Pinheiros www.cemiterioparque.com.br
Daft Logic - GoogleMaps Area Calculator www.daftlogic.com

DeathLAB www.deathlab.org

GreenAcres Woodland Burial www.greenacrescelebrate.co.uk

Memorial Parque das Cerejeiras www.cerejeiras.com.br

Morte sem tabu www.mortesemtabu.blogfolha.uol.com.br

Prefeitura de São Paulo www.prefeitura.sp.gov.br

Promessa - Ecological burial www.promessa.se

Recompose www.recompose.life

Revista M. Estudos sobre a Morte, os Mortos e o Morrer www.revistam-unirio.com.br

Sindicato dos Cemitérios e Crematórios Particulares www.sincep.com.br

The Natural Death Centre www.naturaldeath.org.uk

The World Wide Web Cemetery www.cemetery.org

Urnas de Angeli www.urnasdeangeli.com.br 
Os Gemitérios de São Paulo<smiles>C1CCCC1</smiles>

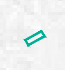<smiles>C1CCCCC1</smiles>

$2 \vdots$

3

4
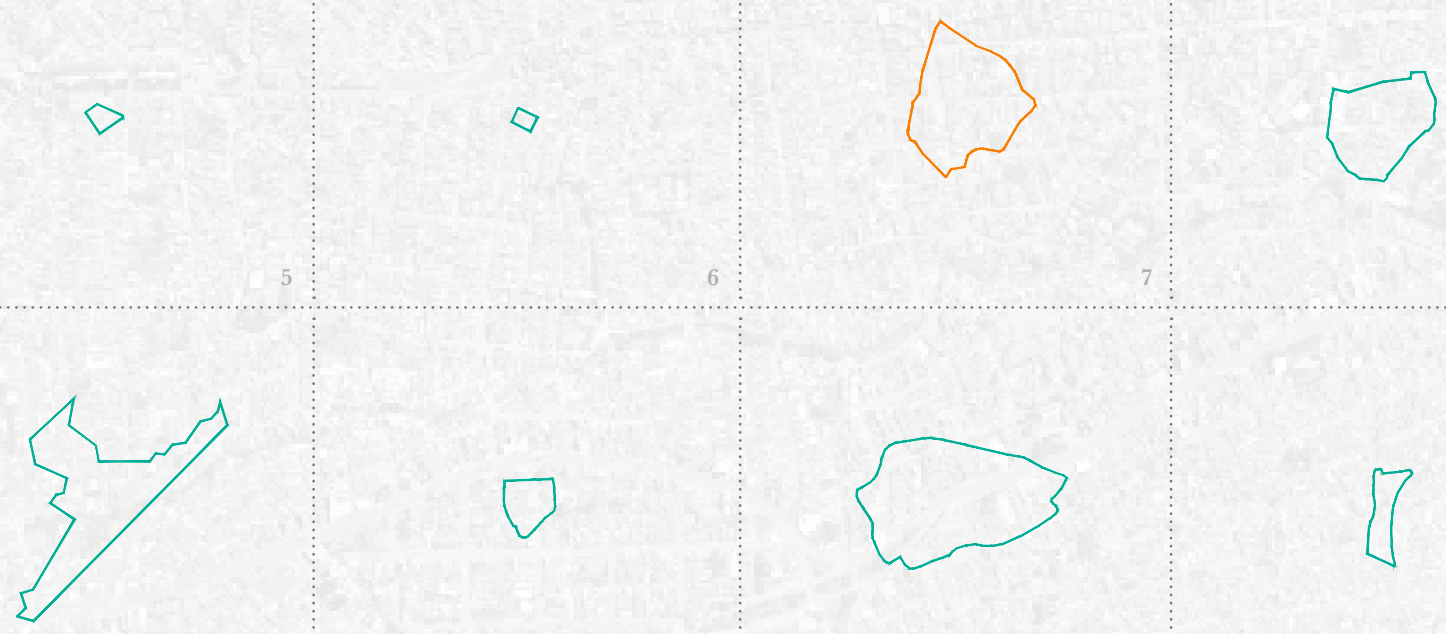<smiles>C1CCC2CCCC2CC1</smiles>

7<smiles>C1=CC2CCC1C2</smiles><smiles>C1CCCCC1</smiles>

$\triangle$

[7

10

11

12

13

15

16

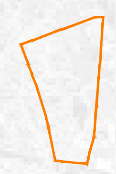<smiles>C1C2CC12</smiles><smiles></smiles>

17

18

19

20

234 
Img.100 Os 40 cemitérios da cidade de São Paulo em fevereiro de 2019 (feito pelo autor) Numeração conforme Img.16, p.100
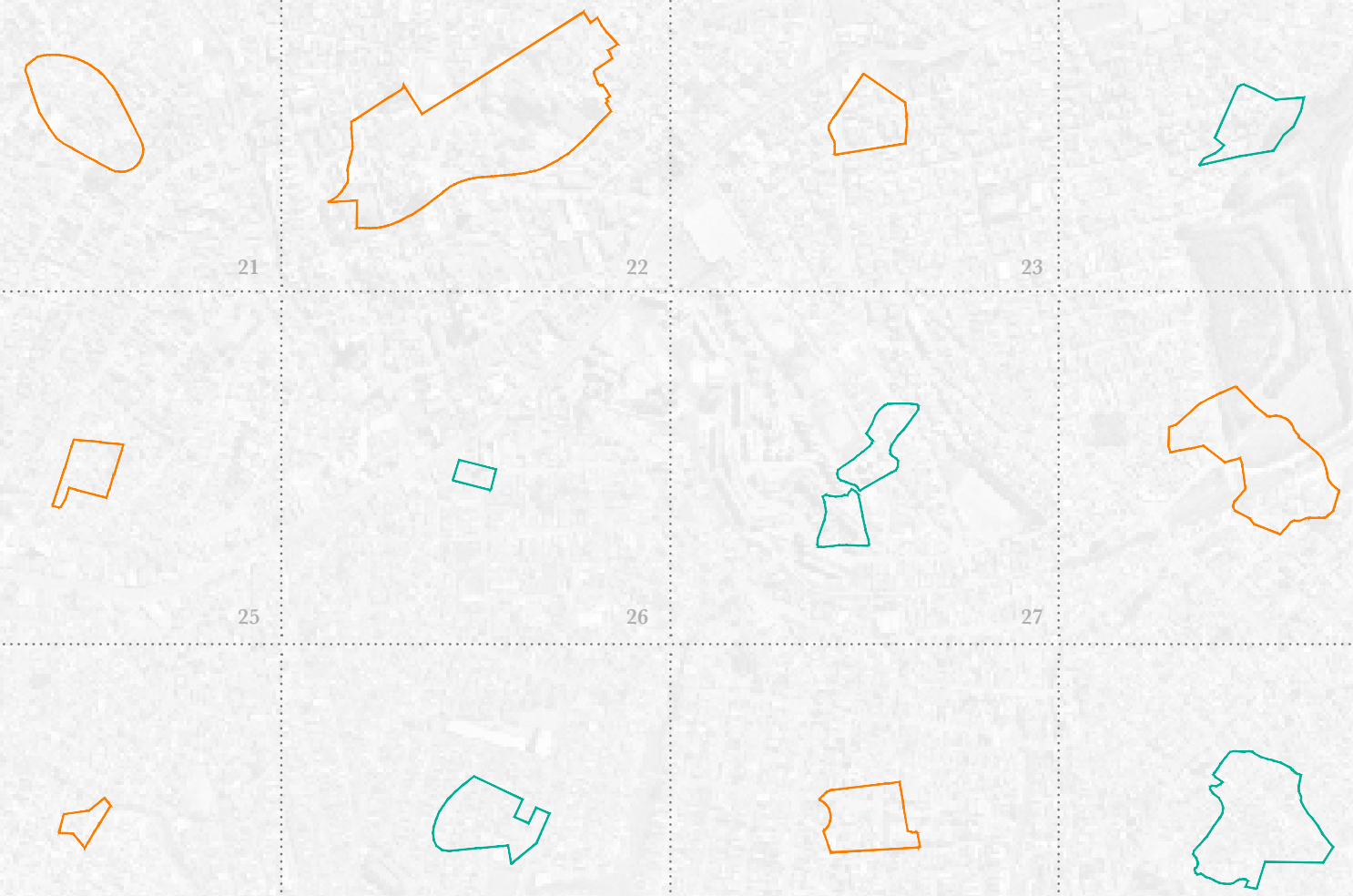

27
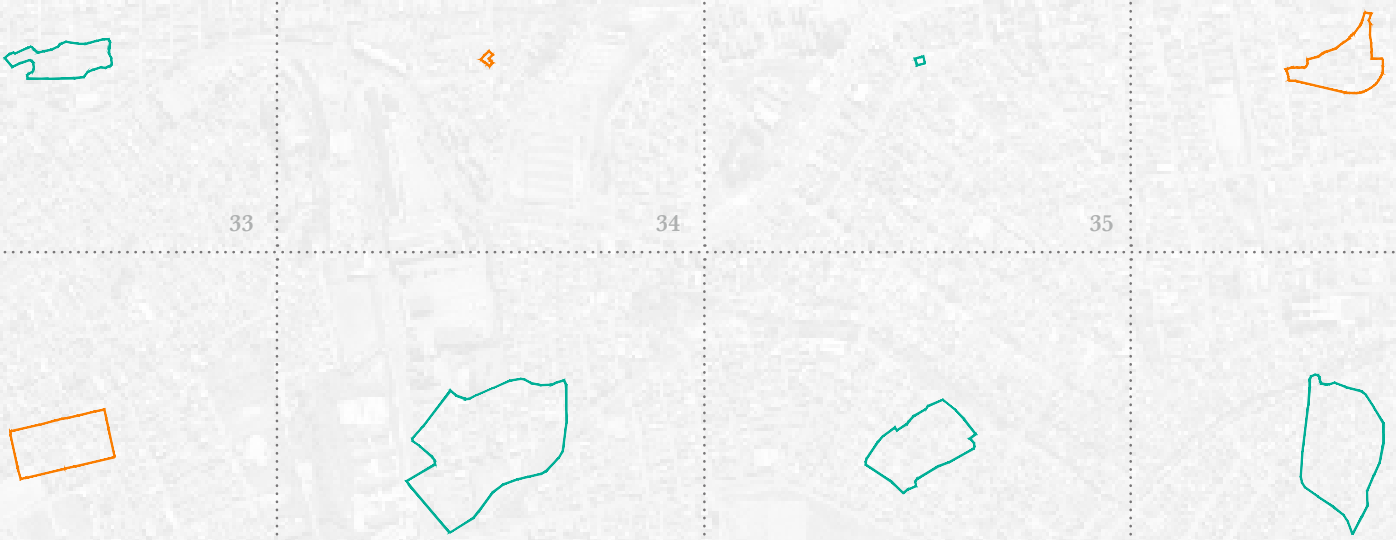


